DOE/EV-0105

$485 /, 8^{8}, 80$ 1.

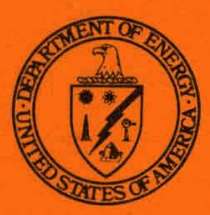

U.S. Department of Energy

Assistant Secretary for Environment

Office of Environmental Assessments

Technology Assessments Division

A Technology

Assessment of

Solar Energy Systems

\title{
Characterization of Solid Waste Conversion and Cogeneration Systems
}

\section{MASTER}

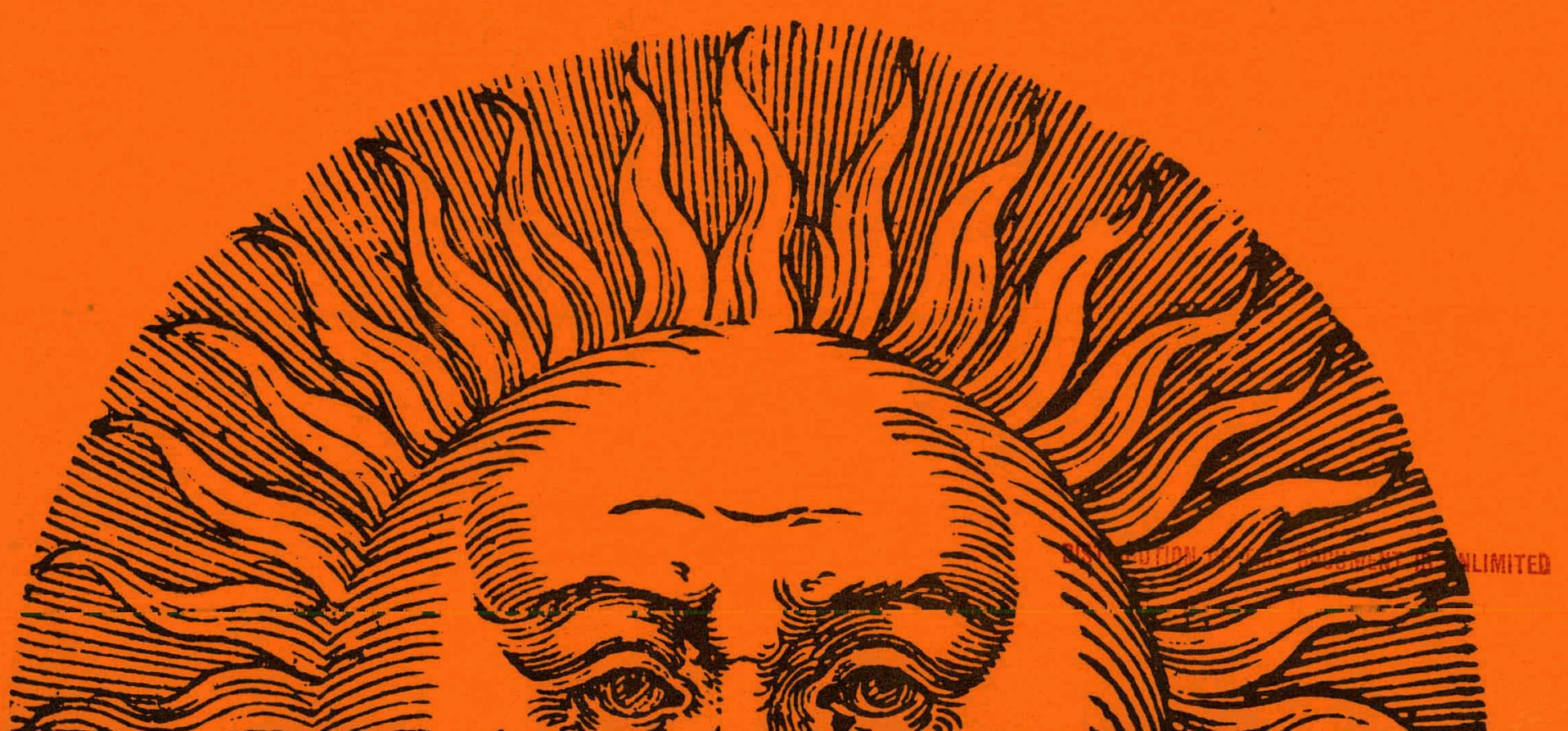




\section{DISCLAIMER}

This report was prepared as an account of work sponsored by an agency of the United States Government. Neither the United States Government nor any agency Thereof, nor any of their employees, makes any warranty, express or implied, or assumes any legal liability or responsibility for the accuracy, completeness, or usefulness of any information, apparatus, product, or process disclosed, or represents that its use would not infringe privately owned rights. Reference herein to any specific commercial product, process, or service by trade name, trademark, manufacturer, or otherwise does not necessarily constitute or imply its endorsement, recommendation, or favoring by the United States Government or any agency thereof. The views and opinions of authors expressed herein do not necessarily state or reflect those of the United States Government or any agency thereof. 


\section{DISCLAIMER}

Portions of this document may be illegible in electronic image products. Images are produced from the best available original document. 
Printed in the United States of America

\section{Available from}

National Technical Information Service U.S. Department of Commerce

5285 Port Royal Road

Springfield, VA 22161

NTIS price codes

Printed Copy: $\quad \$ 14.00$

M1croflche Copy: $\$ 3.50$ 


\section{A Technology Assessment of Solar Energy Systems}

\section{Characterization of Solid Waste Conversion and Cogeneration Systems}

Prepared by:

Lawrence Berkeley Laboratory

\section{U.S. Department of Energy}

Assistant Secretary for Environment Office of Environmental Assessments Washington, D.C. 20545

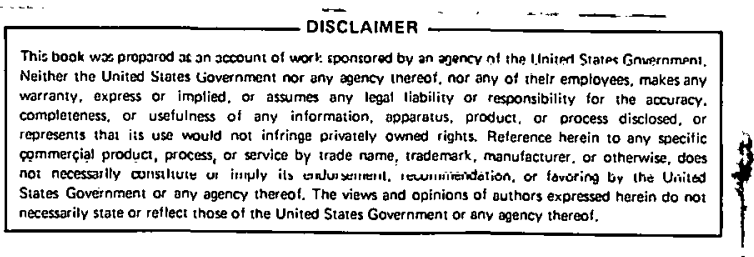


The U.S. Department of Energy, Office of Environment, Office of Environmental Assessments, is conducting a project entitled Technology Assessment of Solar Energy (TASE) Systems, to evaluate the range of potential environmental, health, and socioeconomic consequences of rapid, large-scale commercialization of solar technologies. The goal of this project is to identify and analyze both the positive and negative effects of solar technology deployment. The project will provide a basis for avoiding potential problems and for grasping opportunities during the transition to solar energy in the $U$. S.

Massive solar development will force major increases in the use of those raw materials needed to make solar system components. Along with this increased resource consumption and production will come associated pollution. In addition, rapid solar energy development may mean significant secondary or unplanned changes in institutions and lifestyles as the nation moves toward greater use of solar energy systems. The TASE project is designed to provide a quantitative analysis of the direct and indirect effects of solar energy use. In so doing, it will help define an environmentally acceptable solar future.

This report is an element of the TASE Solar Technology Characterization Series. We would like to express our appreciation to Ron Ritschard and Ken Haven of the Lawrence Berkeley Laboratory for their efforts in preparing this document.

Dr: Gregory J. D'Alessio

TASE Project Director

Technology Assessments Division

Dr. Robert P. Blaunstein, Manager

Conservation, Solar, and Geothermal Programs Technology Assessments Division 


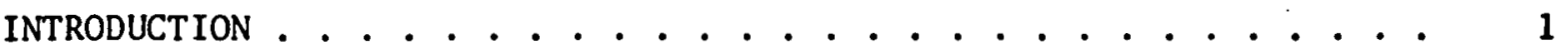

TECHNOLOGY APPLICATIONS . . . . . . . . . . . . . . . 6

Direct Combustion of MSW . . . . . . . . . . . . . . 6

Refuse-Derived Fuel . . . . . . . . . . . . . . . . 7

Technology Summary Sheet - I . . . . . . . . . . . . 9

Technology Summary Sheet - II . . . . . . . . . . . . 13

Pyrolysis . . . . . . . . . . . . . . ..... 19

Technology Summary Sheet - III . . . . . . . . . . . . . . 25

Cogeneration Systems . . . . . . . . . . . . . . . . 27

Fluidized Bed Steam Cogeneration for the Pulp and Paper Industry. 29

Secondary Water Treatment Plant Cogeneration Using Diesel

Systems . . . . . . . . . . . . . . . . . . . . 31

Technology Summary Sheet - IV . . . . . . . . . . . . . 33

Technology Summary Sheet - V . . . . . . . . . . . . . 37

Enhanced Oil Recovery . . . . . . . . . . . . . . . . 39

Technology Summary Sheet - VI . . . . . . . . . . . . . . $4 \underline{4}$

ENVIRONMENTAL DATA . . . . . . . . . . . . . . . . . . 4 43

Direct Combustion . . . . . . . . . . . . . . . . . . 43

Refuse-Derived Fuel . . . . . . . . . . . . . . . . 43

Pyrolysis . . . . . . . . . . . . . . . . . . . 51

Cogeneration Systems . . . . . . . . . . . . . . . . . 51

Fluidized Bed Boiler . . . . . . . . . . . . . . . . . 54

Diesel Engine . . . . . . . . . . . . . . . . . . . . . . . 54

FACTORS INFLUENCING UTILIZATION OF SOLID WASTE CONVERSION AND

COGENERATION .............................. 57

Solid Waste Conversion . . . . . . . . . . . . . . . 57

Cogeneration . . . . . . . . . . . . . . . . . . . 60

CONCLUSIONS . . . . . . . . . . . . . . . . . . . . 64

APPENDIX A: CAPITAL AND OPERATIONAL RESIDUAL INPUT SHEETS FOR SEAS

MODEL APPLICATION . . . . . . . . . . . . . . . . . . 71

Side Equations . . . . . . . . . . . . . . . . . 71 
Page

APPENDIX B: CHARACTERIZATION OF MUNICIPAL SOLID WASTE (MSW)

AND MSW CONVERSION TECHNOLOGIES . . . . . . . . . . . 105

Conceptual Comparison of Landfill and Recovery . . . . . . 105

Characterization of Municipal Solid Waste . . . . . . . . 108

General Characterization of MSW Energy Recovery Systems : . 113

REFERENCES: APPENDIX B . . . . . . . . . . . . . . . 117

APPENDIX C: CURRENT STATUS OF MSW ACTIVITY . . . . . . . . . . 119

REFERENCES: APPENDIX C ................... 139

APPENDIX D: CURRENT STATUS OF COGENERATION SYSTEMS.....$\cdot 140$

APPENDIX E: APPLICATIONS OF COGENERATION SYSTEMS . . . . . . 145

COGENERATION IN THE PULP AND PAPER INDUSTRY: A BRIEF OVERVIEW. 145

Industry Description . . . . . . . . . . . . . . 145

Fuel Consumption .................... . 145

Fuel and Energy Uses . . . . . . . . . . . . . . . . 145

Thermodynamic Potential for Increased Cogeneration . . . . . 147

Economic Potential for Increased Cogeneration . . . . . . . 149

The Effect of Economic Incentives on Potential Implementation

by 1985 . . . . . . . . . . . . . . . . . . . . . . 150

Fluidized Bed System for the Pulp and Paper Industry . . . . 151

ENHANCED OIL RECOVERY . . . . . . . . . . . . . . . . . . 154

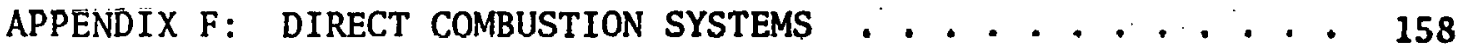

REFERENCES: APPENDIX F . . . . . ............ 167

APPENDIX G: CHARACTERIZATION OF RDF . . . . . . . . . . . 168

APPENDIX H: PYROLYSIS CONVERSION OF MSW . . . ....... 173

Chemistry of Pyrolysis . . . . . . . . . . . . . 173

Pyrolysis System Advantages and Drawbacks . . . . . . . . . 174

PUROX System ...................... 174

Landguard . . . . . . . . . . . . . 181

Garrett Flash ....................... 191

REFERENCES: APPENDIX H . . . . . . . . . . . . . . 203

APPENDIX I: CAPITAL REQUIREMENTS . . . . . . . . . . . . 205 .

INTRODUCTION . . . . . . . . . . . . . . . . . 205 
Page

DIRECT COMBUSTION . . . . . . . . . . . . . . . 208

$\mathrm{RDF}$. . . . . . . . . . . . . . . . . . . . 208

PYROLYSIS . . . . . . . . . . . . . . . . . 209

FLUIDIZED BED . . . . . . . . . . . . . . . . . 209

ENHANCED OIL RECOVERY ..................... . . 210

DIESEL . . . . . . . . . . . . . . . . . 210

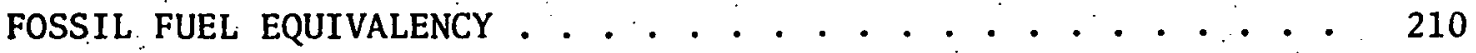

REFERENCES ......................... 213 
1 Summary of Current and Projected MSW Energy Recovery Operational Plants............. 3

2 Summary Direct Combustion Inputs and Outputs . . . . . 11

3 Annual Production of RDF as a Function of Facility Sizé.................... 15

4 RDF System Input/Output Summary . . . . . . . . . . 18

$5 \quad$ PURoX Inputs and Outputs per $10^{12}$ Btu Output . . ... 28

6 Summary of Fluidized Bed Cogeneration Inputs and

7. Dieșel Cogeneration System Input/Output Summary . . . 38

8 Summary of Enhanced Oil Recovery Inputs and Outputs . . 42

9 . Direct Combustion Average Stack Effluent Characteristics 44

10 Direct Combustion Waterborne Residuals . . . . . . . 45

11 Stack Gas Emissions .. . . . . . . . . . . . . . 49

12 Comparison of Ash Pond Effluents . . . . . . . . . . . 49

13 Residuals from Typical RDF System . . . . . . . . . 50

14 Residual Concentration for PUROX System . . . . . . . 52

15 Summary of Cogeneration Residual Generation . . . . . . 53

16 Systems Inputs Comparison . . . . . . . . . . . 65

17 Systems Output Comparison . . . . . . . . . . . . 66

18 Stack Effluents Comparison . . . . . . . . . . . 67

19 Waterborne Residuals Comparison . . . . . . . . . 69

20 Summary of Major Environmental Problems . . . . . . . 70

A-1 MSW Technology Side Equations . . . . . . . . . . 72

B-1 MSW Material Components from Various Studies . . . . . 110

B-2 MSW Chemical Composition from Various Studies . . . . 111

B-3 Major Residuals Generated by a Municipal Solid Waste

C-1 Current Operationál Activity in MSW Energy and Resource Recovery . . . . . . . . . . . . . . . . 120

C-2 U.S. Companies Currently Active in MSW Energy Recovery System Operation, Manufacturing or Design . . . . . . . 128

C-3 Current Research Projects in MSW Energy Recovery . .. . 130 
Table

C-4 MSW Energy Recovery System Efficiency Comparison . .

D-1 Cogeneration Systems . . . . . . . . . . . .

D-2 Potential for Expanded Enhanced Oil Recovery in California . . . . . . . . . . . . . . 143

D-3 Cogeneration . . . . . . . . . . . . . 144

E-1 Region Distribution of the Pulp and Paper Industry . 146

E-2 Maximum Potential for Inplant Generation of Electricity .................. 148

F-1 Typical Gas Compositions for Conventional and SteamGenerating Incinerators ............ 160

G-1 Comparison of Raw Refuse and RDF . . . . . . . . 169

G-2 Comparison of the Chemical Composition of Fuels . . 170

H-1 The Effect of Temperature on Pyrolysis Yields . . . 174

H-2 Simple Pyrolysis . . . . . . . . . . . . . 176

H-3 Advantages and Drawbacks of Pyrolysis Systems . . . 177

H-4 Typical PUROX Fuel Gas Analysis . ... . . . . . . 178

H-5 Comparison of PUROX Gas and Other Gaseous Fuels . . 179

H-6 Average Slag Analysis . . . . . . . . . . . . 180

H-7 PUROX Inputs and Outputs per $10^{12}$ Btu Output . . . 186

H-8 : Landguard System Input/Output Summary . . . . . . . 190

H-9 Landguard Stack Effluents per $10^{12}$ Btu Output . . . 192

H-10 Landguard System Stack Residuals . . . . . . . . . 193

H-11. Landguard System Economics . . . . . . . . . . . 194

H-12. Garrett Flash Pyroloysis Products . . . . . . . 195

$\begin{array}{lll}\text { H-13 Sumnary of Major Inputs and Outputs for the Garrett } & \\ & \text { Flash Pyrolysis Process . . . . . . . . . . . . } 201\end{array}$

H-i4 Garrett Process Residuals . . . . . . . . . . . 202

I-1 System Fossil Fuel Equivalency . . . . . . . . 211 
1 Waterwa11 Process Flow Diagram . . . . . : . . 8

2 Shredded Air-Classified RDF System ... . . . . . . 16

3 MSW Pyrolysis Schematic Diagram ......... . . 21 ,

4 Flow Diagram of Union Carbide System . . . . . . . . 24

5 Fluidized Bed Cogeneration for Pulp and Paper Plant . 32

6 . Energy Flows for Sewage Treatment Plant Cogeneration

System . . . . . . . . . .......... 36

7 . Thermally Enhanced Oil Recovery Cogeneration System . 40

8 Effect of Columetric Gas Flow Rate on Particulate Emissions ....................447

$9 \quad$ Cogeneration System Alternative Analysis . . . . . 61

B-1 Systemic Schematics for a Landfill and for a Resource Recovery System . . . . ............. 107

B-2 Nomograph for Calculation of Total Energy Value of MSW . . . . . . .............. 112

B-3 Municipal Solid Waste Resource Recovery . . ..... 114

B-4 Resource Recovery Module . . . . . . . . . . . 115

E-1 Energy Flows for Thermally Enhanced 0il Recovery

Cogeneration . . . . . . . . . . . . . . . . 157

F-1 MSW Direct Incineration . . . . . . . . . . . . 159

F-2 Incinerator Flue Gas Volume as a Function of Percent

Excess Air . . . . . . . . . . . . ... 162

F-3 Direct Combustion Material Balance . . . . . . . . 163

F-4. Direct Combustion Energy Balance . : . . . . . . . 164

F-5 Fossil Fuel Equivalency for MSW Direct Conversion Systems . . . . . . . . . . . . . . . . 166

G-1. RDF System-Materials Balance . . . . . . . . . 171

G-2 RDF System-Energy Balance . . . . . . . . . . 172

$\mathrm{H}-1$ : Gas Production-Laboratory Pyrolysis of Municipal Solid Wastc . . . . . . . . . . . . . . . 175

H-2 PUROX System Material Balance ............. 182

H-3 PUROX System Energy Balance . . . . . . ..... 183

H-4 Methanol Converter Syst-m Input/Output Diagram.... 184

H-5. Methanol from Refuse-Flow Diagram .......... 185 
Figure . . Page

H-6 Landguard Pyrolysis System Mass Balance ....... 188

H-7 Landguard Pyrolysis System Energy Balance . . . . 189

H-8 Garrett Flash Pyrolysis Front End System . . .. . . 196

H-9 Energy Consumption for Primary and Secondary Shredding 198

H-10 Garrett System Material Balance . . . . . . . . . . I99

H-11 Garrezt Process Energy Balance ... . . . . . . . 200

I-1 Plant Capital Cost as a Function of Plant Size . . . 206

I-2 Employment Requirements for Various Site Plants . . 207 
INTRODUCTION

The Technology Assessment of Solar Energy Systems (TASE) is being conducted by the Division of Technology Overview (Office of Technology Impacts) of the Office of the Assistant Secretary for Environment (ASEV/OTI/DTO) of the Department of Energy (DOE). Analytical efforts have been undertaken by several of the DOE national laboratories for Phase I of the TASE program. This report presents the Phase I assessment of assigned technologies by the Lawrence Berkeley Laboratory (LBL). Two renewable resource technologies have been allocated to LBL for analysis in the TASE program: Municipal Solid Waste (MSW) energy conversion and cogeneraton.

The primary objective of the TASE prograin is to determine the probable consequences to the environment and to public health and safety resulting from widespread implementation of major solar and renewable resource technologies. The specific principal Phase I objective is to determine the levels of residuals most likely to result throughout the complete energy cycle from the utilization of each of the solar and renewable resource technologies.

At a time of rising energy prices and diminishing domestic supplies of crude oil and natural gas, many municipalities are also faced with a solid waste management crisis. The cost of direct landfill disposal is rising and available landfilled sites are becoming scarce in many areas. Recovery of energy resources from MSW presents a partial solution to both areas. MSW energy recovery can reduce the mass of landfilled wastes by as much as 95 percent and can tap a vast new energy resource. The yearly collection of MSW is estimated to be 125 million tons nationwide (Lowe, 1974). The typical energy content of raw MSW is $4500 \mathrm{Btu} / \mathrm{lb}$. Thus, the maximum potential energy resource base is enormous $\left(1.25 \times 10^{15}\right.$ $\mathrm{Btu} / \mathrm{yr}$ ).

Three basic technologies for recovering energy from MSW are considered in this study. These are: (1) direct combustion using a waterwall incinerator in which the heat from burning refuse is converted to stean by circulating water in steel tubes jacketing the interior of the incinerator; (2) manufacture of a relatively uniform shredded, pulverized or pelleted refuse-derived fuel (RDF) for supplemental firing in a utility boiler; and 
(3) pyrolysis or destructive distillation of MSW to extract a low-Btu fuel gas. While resource recovery and energy recovery systems can be installed independently, the processes described here include both energy and resource recovery systems as well as necessary, pollution control equipment for gaseous emissions. While it is realized that other MSW resource recovery technologies are being developed (e.g. anaerobic digestion or methane recovery from landfills), only the three technologies mentioned above have been selected for inclusion in this study.

Initial MSW energy recnvery in the United States involved the retrofit of waste heat boilers onto existing incineration units. Additionally various incinerators have been retrofit with direct waterwall heat recovery systems. Beyond the direct combustion techniques, MSW energy recovery. technology has not reached a level of development associated with on-line commercial application. Rather, existing RDF and pyrolysis plants are supported as either test plants or as demonstration plants. The principal problems associated with commercialization of these technologies have been technical performance problems with existing system designs and failure to successfully market facility energy products (Schnelle and Yamamoto, 1974).

Current "on-1ine" and planned MSW energy and/or resource recovery plants are listed in Appendix C (Table C-1). Additionally, Appendix C contains a list of private companies involved in MSW research and development (Table $\mathrm{C}-2$ ), and an inventory of current research activities (Table $(-3)$. Table 1 summarizes the current and projected on-line capacity and approximate electrical energy generating plant equivalent. The resulting total 1985 MSW energy capacity of 3135 MWe is conservative since required lead time for most MSW energy recovery plant types is less than four years (plants could be on-1ine in 1985 and not announced until late 1980).

At the other (optimistic) end of the possible forecasting spectrum, St. Clair (1975) reported on the results of a survey of U.S. cities in which 33 percent of all responding cities with populations over 100,000 and 45 : percent of a11 cities responding with populations over $250,000 \mathrm{plan}$ to adopt capital-intensive MSW resource and/or energy 
Table 1

Summary of Current and Projected MSW Energy Recovery Operational Plants

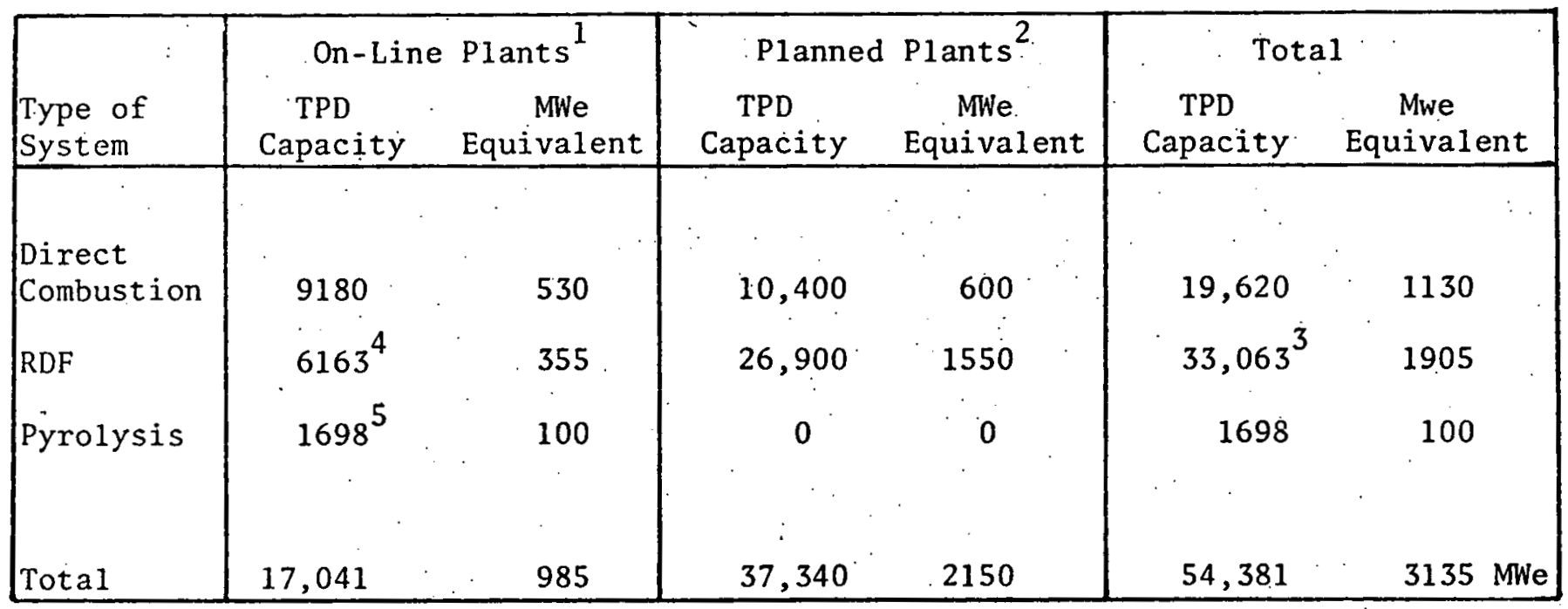

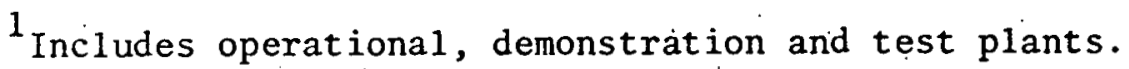

${ }^{2}$ All Planned Plants are scheduled to.be on-line by $1985^{\circ}$

${ }^{3}$ Plant Capacity (MVe) at 60 percent capacity load factor required to generate the amount of electrical energy which could be produced from MSW using mean conversion efficiencies listed in Table C-4 of this report.

${ }^{4}$ Includes $325-T P D S t$. Louis plant no longer on-1ine.

${ }^{5}$ Includes 75-TPD Erie County, N.Y. plant and 1000-TPD Baltimore plant, neither of which is currently on-line. 
recovery facilitics by 1980 . Extrapolated across the country, this wolid indicate a near-term MSW energy capacity of as much as 40,000 . Me. Actual 1985 on-line MSW energy recovery may be expected to fall somewhere between these two extreme values.

The principal forecasting implication of Appendix $\mathrm{C}$ is that near-term MSW energy recovery activity will be dominated by direct combustion and RDF systems with pyrolysis gaining real importance in the long term (1990 or later) based upon the results of ongoing pyrolysis testing and research.

Cogeneration has recently received increased attention from utilities, industries, and those involved in the public policy of energy supply and demand. Interest is based on the very high energy efficiency and the possibility of reduced emissions from power generation. Cogeneration systems are modified power plants which provide both electricity and process heat or isteam, such as required by many industries and some large commercial and residential buildings. The systems may use steam boilers, steam turbines, electric generators, gas turbines, diesel engines, and waste heat boilers. Traditionally, cogeneration has been a system where high pressure steam is used in a turbinc to generate electric power and low-pressure steam, which is used for its heating value in an industrial process. There are other equally valid processes using the same principle.

Three end use applications of cogeneration systems are characterized in this report. The end uses analyzed include: (1) fluidized bed cogeneration systems for use in the pulp and paper industry; (2) diesel system using the digested sewage gas of a sewage treatment plant for electricity generation as well as heating and pumping; and (3) an enhanced oil recovery system.

No new technology is needed for cogeneration systems and, in fact, a few cogeneration systems have been operating for many years. Though common in Europe, cogeneration has steadily declined in the United States, largely because of institutional barriers and transition costs. Nevertheless, functionally cogeneration is quite attractive because of its very high efficiency of fuel use, corresponding decrease in pollution and negligible consumption of water. For these reasons, 
people are advocating public policies to remove institutional barriers and encourage cogeneration. Estimates of the cogeneration capacity of the United States in 1985 range from 20 to $250 \mathrm{GW}$.

To meet the Phase I objective, LBL staff have characterized the individual application associated with each general technology; calculated operational residuals.generated by each application; determined the input capital requirements and, when possible, annual operating input requirements; and have identified the technical and institutional constraints for the widespread implementation of each application.

A description is presented of the energy and material development cycle required for the implementation of each technology. In addition, the capital requirements are compiled and presented in a SEAS system format. These capital costs will'be used at a later time to compute the material demands and capital residuals.

Based on the technology characterization, estimates of the operating residuals per $10^{12}$ Btu of energy produced are made for each stage in the energy cycle. The results of this analysis, which represented the expected level of pollutants discharged to the environment, will be used in Phase II to determine the environmental impact of these selected technologies as a function of the number of quads of energy. produced and are summarized in SEAS input format in Appendix A. 
TECHNOLOGY APPLICATIONS

Direct Combustion of MSW

Introduction

Of the three MSW energy recovery technologies considered for this study only direct combustion systems depend entirely upon existing equipment and processes. Direct combustion systems generally involve no front end systems but rather load MSW directly into incinerators. They may be differentiated from RDF systems by this absence of prc-processing of received refuse which is a necessity in the RDF process. In general, MSW is delivered directly into an incinerator and burned with the resulting heat being partially recaptured through boilers or, much less often, through gas turbines. The char is removed to either a resource recovery process or is land filled, and the waste gas stream is treated and released after energy recovery. Several direct incineration systems, however, do employ coarse shredders before incineration. Further preprocessing would shift this process to an RDF process. Only two basic energy products may be obtained from direct combustion systems: steam and electricity:

There are two general types of direct combustion systems currently being used in the U.S.: refractory wa11 incinerators and waterwall incinerators. Steam is a basic energy product of both systems which can be converted to electricity in a steam turbine. Refractory wall incinerators have been used for many years as MSW volumetric reduction incinerators. In volume reduction incineration no energy is recovered and all heat escapes up the plant stacks. The conversion of such a plant to a steamproducing plant conceptually requires only the insertion of a boiler between the incinerator and the stack.

Waterwal1 1ncineration technology lias existed in the U.S. for 25 years and was designed specifically for energy recovery operations. In a waterwall incinerator steam boiler tubes are located along an upper wall of the incinerator, and steam is generated directly in the incinerator. A more detailed review of these two systems and of their operating characteristics is contained in Appendix $F$ tọ this report. 


\section{Technology Description}

Because of its smaller waste gas flow and lower waste gas water vapor content, a waterwall incinerator system was selected as the model application for direct combustion technology. Figure 1 shows a detailed process flow diagram for a typical waterwall incinerator system. MSW is received directly from local collection trucks into a large holding pit from which material is transferred by crane into the waterwall furnaces. Bulky items are separated and shredded prior to incineration. Furnace temperature is maintained at $1700^{\circ} \mathrm{F}$ to $1800^{\circ} \mathrm{F}$ to avoid slagging. Solid residue is quenched and undergoes a resource recovery process as described in Appendix B. This type of system, exemplified by the Wheelabrator-Frye design, can operate with as little as $70 \%$ excess air instead of the $250 \%$ to $300 \%$ typical of refractory wall incinerators. Output steam is usually in the range of $400-600 \mathrm{psi}$ and $500-700^{\circ} \mathrm{C}$. Electrostatic precipitators are used to clean the gas stream prior to discharge. Major technological characteristics of this system are summarized in the Technology Summary Sheet - I.

The major inputs and outputs from this system are summarized in Table 2. As shown, energy recovery efficiency is $69.9 \%$ and total system efficiency (including ancillary energy requirements) is $68 \%$. The system, as shown in Table 2, produces $1 \times 10^{12}$ Btu of steam per year and this represents approximately $1.25 \times 10^{12}$ Btu of fossil fuel equivalent energy. This equivalent represents an annual savings of approximately 50,000 tons of cual. Furthcr dotail on this equivalency calculation is provided in Appendix F. Residual concentrations are included in the Environmental Data section.

Refuse-Derived Euel

Introduction

Municipal solid wastes (MSW) contain substantial quantities of combustible material such as paper, plastics, wood and other organic fiber. Since MSW varies in composition from area to area, the resulting refuse 


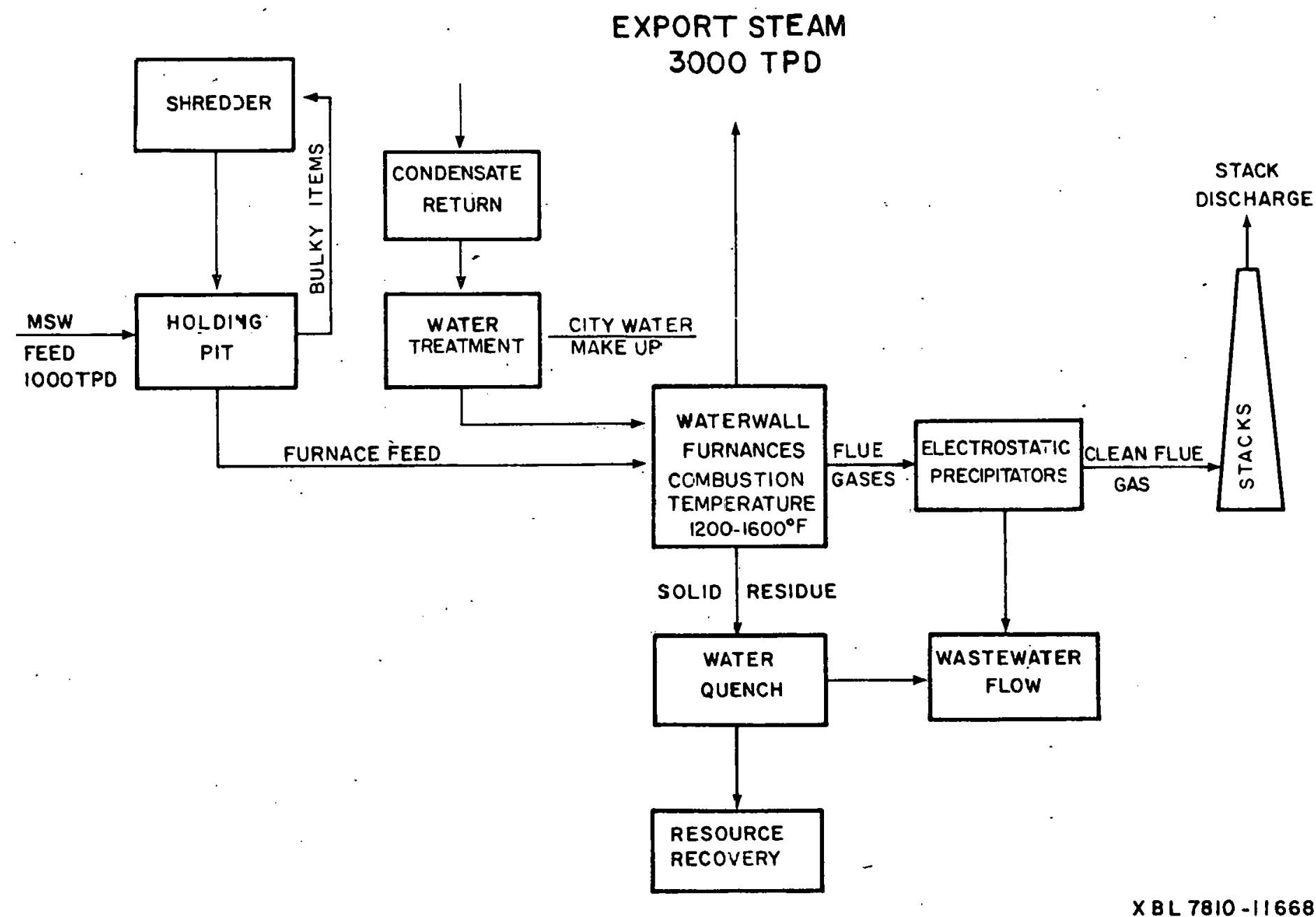

Fig. 1. Watèrwall Brocess flow niagram 
TECHNOLOGY: Direct Combustion of MSW

DESCRIPTION: Direct combustion systems involve the aerobic combustion of MSW without any preprocessing of the received MSW prior to incineration. Waste heat is captured by either steam boiler tubes inserted directly into the furnace (waterwall system) or through a separate boiler (refractory wall). Produced steam may be used directly or converted to electrical energy. Solid char residual may be directly landfilled or subjected to iron, aluminum and glass recovery processes. Waterwal1 systems require less excess air (100\%-150\%) than refractory wall systems $(250 \%-350 \%)$, and burn at slightly higher temperatures $\left(1100-2000^{\circ} \mathrm{F}\right)$ than refactory wall systems $\left(900^{\circ}-1500^{\circ} \mathrm{F}\right)$. Plant capacities for both waterwall and refractory wall systems vary from several hundred to several thousand TPD with greater economies of scale possible at the higher plant capacities. Product steam quality can vary up to the range of $750^{\circ} \mathrm{F}$ and $600 \mathrm{psi}$.

DESIGN SELECTION

CRITERIA: Direct combustion has been selected for characterization for several major reasons. First, the system uses only existing, "off-the-shelf" technology. Second, it is a low-cost alternative. Third, it is compatible with many existing municipal incinerators used to reduce the volume of 1 andfill material. Fourth, it is currently being used in over 50 cities within the United States.

The waterwall system was selected for characterization because its lower off-gas flow rate increases the efficiency of emissions control equipment and decreased residual flow rates, because the system has a higher efficiency, and because average costs are slightly lower than refractory wall systems.

END USE: Steam - either for district hearing or fur industrial process heat. 
TECHNOLOGY SUMMARY SHEET - 1 (continued)

RESIDUALS: The basic system design includes both electrostatic precipitators and scrubbers. However, significant flows of both air and waterborne residuals are generated which result in the highest residual generation rate of all MSW energy recovery systems. Stack, gas includes $\mathrm{NO}_{x}, \mathrm{CO}, \mathrm{HCl}, \mathrm{NH}_{3}$, particulates and $\mathrm{SO}_{2}$. While the scrubber waste flow is acidic, high in dissolved solids and hardness, the quench waste has a pH of 9.9, is high in suspended solids and is $90^{\circ} \mathrm{C}$ at the outlet. 
Table 2

Summary of Direct Combustion Inputs and Outputs

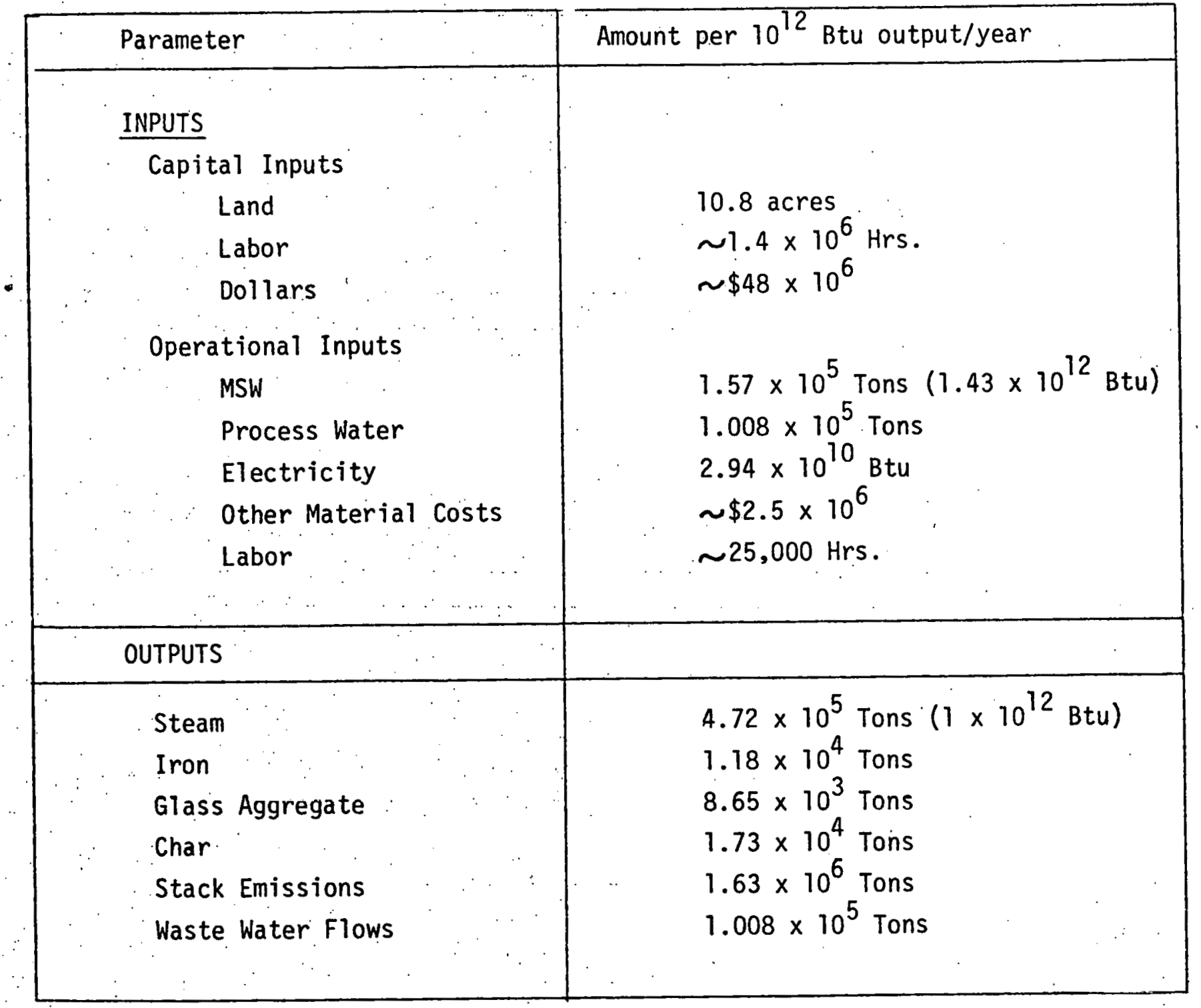


fuel may also have a different content. Appendix $G$ contains a brief discussion of the chemical characterization of RDF. If properly processed, MSW can serve as an energy source offering the advantage of "tapping" an otherwise wasted material. 'Its use can decrease demand for more conventional fossil fuels such as natural gas, oil or coàl. Utilization of MSW also greatly reduces the volume of refuse for disposal, thus relieving pressure on landfill operations.

Several of the methods proposed for the mechanical processing of MSW -for resource recovery produce a low bulk density fraction suitable for use as a fuel. The list of conversion processes includes:

- 1) wet processing (hydropulping) followed by component 3eparation and dewatering of the fuel fraction. This process is demonstrated by Black Clawson at Franklin, Ohio.

2) dry processing (shredding) followed by chemical processing to produce what is called ECO-Fuel II. This process is demonstrated ! by the Combustion Associates plant at East Bridgewater, Massachusetts; and

3) dry processing (shredding) followed by air classification. r. This process is demonstrated by severa1 projects including Union $\therefore$. Electric in St. Louis and the cities of Ames and Milwaukee. The technology description will focus on the finely shredded airclassified fuel, since the major part of the experience relates to this technology. The product is combustible with a reasonably high heat of combustion and is being utilized as a supplementary fuel in the utility boilers at several locations (see Appendix C). In Technology-Sumnary Sheet - II is a description of the RDF technology selected as the model system for the analysis.

\section{Technology Description}

The co-combustion of RDF with a fossil fuel in a modern power plant is a very cost-effective form of incineration (Klumb, 1976). The major advantage is its low investment cost, if existing furnaces and boilers are used, when compared with other alternatives. Use of RDF as a fuel 
TECHNOLOGY: Refuse Derived Fue1

DESCRIPTION: Municipal solid waste contains many valuable constituents which can be extracted by the RDF process and used for fuel. Because the composition of the input waste changes with time and location, there is no standard figure of merit which defines the precise heat value of this. fuel. . Despite this non-uniformity, the co-combustion of RDF with coal or oil can significantly reduce our dependence on more conventional fuels.

In this process solid waste is collected, shredded, air classified, transported and burned. Alternative processes use hydropulping instead of shredding. Costs are related to the degree of MSW preparation and the value of the derived fuel.

DESIGN SELECTION

CRITERIA: The design is based on the Horner and Shifrin RDF system used in the city of St. Louis. The process assumed the outputs, including residues, related to an input of 1000 tons per day. The system produces an approximated 725 tons per day of refuse-derived fuel which has an average heat value of $11.4 \times 10^{6} \mathrm{Btu} / \mathrm{Ton}$. The Horner and Shifrin system was selected because it has been employed successfully to process MSW into a fuel that can be co-fired with coal in a utility boiler. Furthermore, there is extensive literature available which describes the technical and environmental concerns of the process.

END USE: RDF combustion results in process steam production which has a typical value of $7.19 \times 10^{6}$ Btu per ton of MSW input at 63 percent efficiency.

RESIDUALS: Process residuals include heavy metals, ash, water emissions and air emissions such as $\mathrm{NO}_{x}, \mathrm{Cl}, \mathrm{SO}_{2}$, and particulates. Shredders produce noise emissions, odors, and airborne particulates. 
source requires more processing than does direct burning. Such processing results in the expenditure of capital monies as well as the annual cost of operation and maintenance. Table 3 summarizes cost estimates for three different sized RDF systems. The cost of processing is a complex function of several variables, including:

1) Size of RDF processing facility

2) Location of RDF processing facility and points of RDF use

3) Operating schedule

4) Cost of MSW received

5) Cost of energy

6) Cost of alternative means of municipal refuse disposal

7) Marketablitty of rerlatmed materials surh is ferrums metals, aluminum and glass.

8) Costs of obtaining raw garbage.

In the shredded RDF system (see Figure 2), the refuse is delivered to a preparation area where bulky items (e.g., mattresses) are separated or sheared to a size the shredders can handle. The refuse is fed into a hammermill that shreds the refuse to $8-13 \mathrm{~cm}$. (3-5 in.) particles. The shredded material is air classified to separate the light fraction (about 80 percent of the input refuse) which are primarily the combustible materials and the heavy non-combustible fraction (20 percent of input MSW).

The heavy fraction from the air classifier goes to a magnetic separator which removes the ferrous metals that are cleaned and sold as scrap. The rest of this fraction is compacted and sent to a landfill. It is possible to process this inert fraction through a series of steps to recover usable materials such as glass, aluminum and other metals.

The light fraction from the air classifier is sent to a secondary shredder (fine shredder) where it is reduced in size to $2.5 \mathrm{~cm} .(1-2$ in.) particles. This low density RDF can be piped over short distances or temporarily stored and then hauled by truck over long distances to the utility. Pollutant sources at the processing plant include dust from the shredders and air classification systems, sound from equipment operation, odors, water-borne contaminants from wash of storage areas, and residue destined for landfill. 
Table 3

Annual Production of RDF as a Function of Facility Size

\begin{tabular}{|c|c|c|c|c|}
\hline . & & \multicolumn{2}{|c|}{ Plant Size } & \multirow[b]{2}{*}{$\begin{array}{r}250 \\
\operatorname{ton} / \text { day } \\
\end{array}$} \\
\hline Processing Capacity & Units & $\begin{array}{c}1,200 \\
\text { ton/day }\end{array}$ & $\begin{array}{c}500 \\
\text { ton/day }\end{array}$ & \\
\hline $\begin{array}{l}\text { Amual Average } \\
\text { Refuse Injut }\end{array}$ & tons/lay & 1,200 & 500 & 250 \\
\hline $\begin{array}{l}\text { Actual Refuse Per } \\
\text { "Oorking Day } 1\end{array}$ & tons/day & 1,630 & 700 & 350 \\
\hline Required Process Rate ${ }^{2}$ & tons/hr & 120 & 50 & 25 \\
\hline Nominal Output ${ }^{3}$ & tons/!ır & 150 & 65 & 35 \\
\hline RDF Produced & tons/yr & 343,200 & 143,000 & 71,500 \\
\hline Ferrous :letal Salvage & tons/yr & 29,130 & 12,135 & 0,070 \\
\hline Reject Mlaterials & tons/yr & 65,700 & 27,380 & 13,690 \\
\hline lleat value of Ri)F & Btu $\times 10^{12}$ & 3.84 & 1.60 & 0.50 \\
\hline
\end{tabular}

${ }^{1}$ Based on j-slay work week, 260 days/yr.

2 Based on a 14-hr. day processing operation.

3 Based on an $30 \%$ production factor to account for unscheduled down-time. 


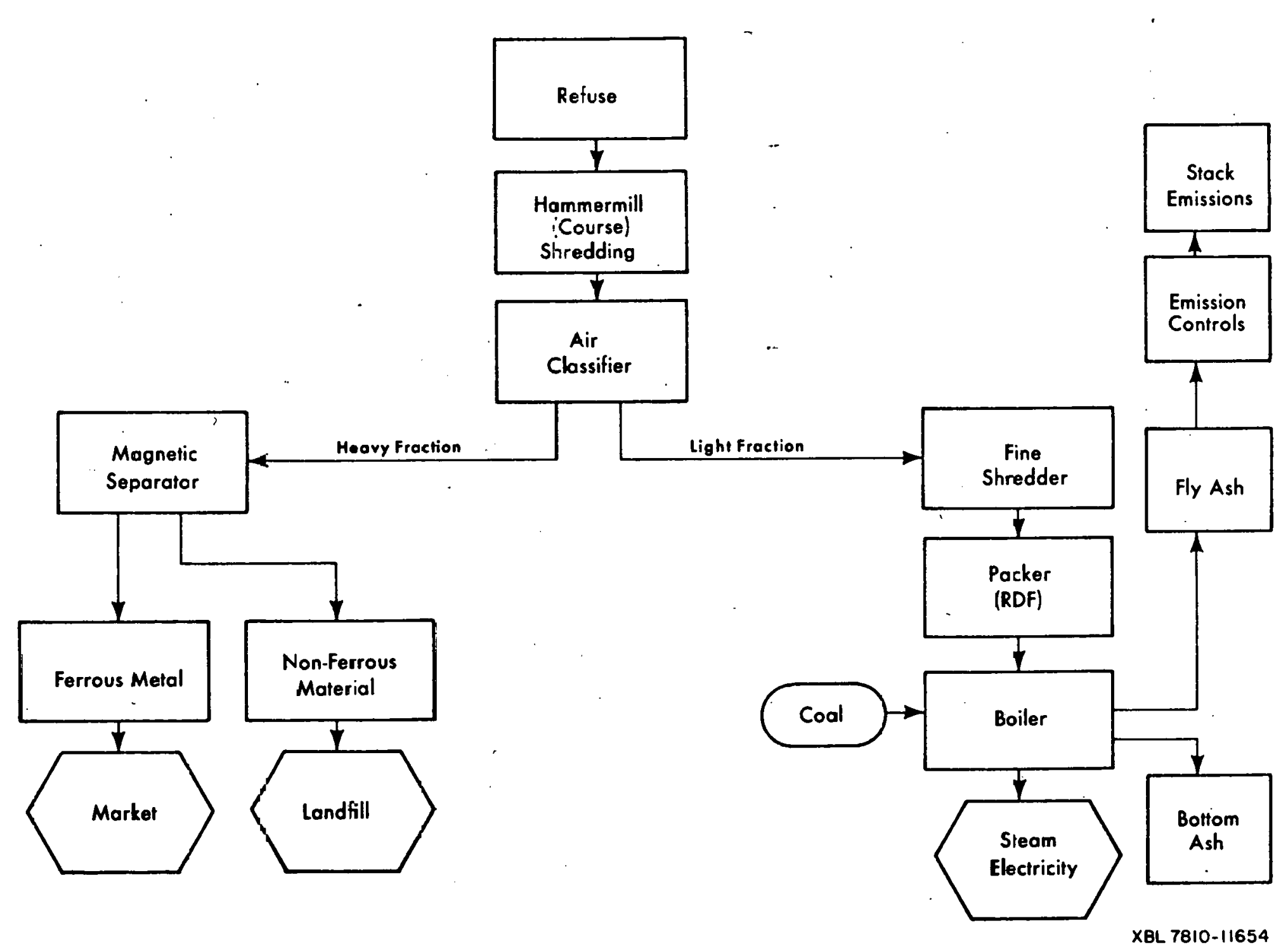

Fig. 2. Shredded Air-Classified RDF System 
At the power plant RDF is unloaded into a receiving bin and is transferred pneumatically into storage bunkers. From the storage bunker the RDF is conveyed by pipelines into the boilers and fired in suspension. Sufficient velocity is imparted to the particles to carry them into the high temperature zones where along with coal, the particles ignite and burn. The refuse firing system is designed to provide from 10-20 percent of the boiler input heat. Light particles are carried out with the flue gas. Ash and heavy unburned particles fall into the boiler ash pit and become part of the bottom ash.

Principal pollutant sources at the power plant are the boiler stack particulate emissions, stack gaseous emissions, bottom ash residue, and sluice water used to hydraulically convey boiler residue to the ash disposal impountment. Various equipment is employed to control particulate and gaseous emission, including electrostatic precipitators, Venturi scrubbers, cyclones, and baghouses.

The technology description given above represents the Horner and Shifrin fuel recovery process, which was operated by the city of St. Louis from 1972 to 1977. Table 4 contains a summary of the input and output of the described RDF system. The values used represent the best estimates from the St. Louis project (Kigore, et al., 1976; Klumb, 1976; and Sheng and Alter, 1975). A material and energy balance for the Horner and Shifin RDF system are illustrated in Appendix G (Figures G-i and G-2).

With the St. Louis approach as a pattern several applications of the basic process have been employed in other locations. For example, the city of Milwaukee has its total volume of MSW (1200 tons/day) handled by a resources recovery system. Like the St. Louis system, refuse is shredded through two shredders and air classified into light and heavy fractions. About 7 percent of the refuse (e.g., newspaper and corrugated material) is removed before the initial shredding process. After magnetic separation, ferrous metals, glass, and aluminum are segregated and marketed. Another example is the 200 ton/day recovery system which began operation in September 1975 in Ames, Iowa. Both of these operations have proven capable of consistently processing both commercial and residential 
Table 4

RDF System Input/Output Summary

\begin{tabular}{|c|c|}
\hline INPUTS & Amount per $10^{12}$ Btu steam mitput per Year \\
\hline $\begin{array}{l}\text { Land } \\
\text { Capital Costs } \\
\text { Isirb } \\
\text { Water } \\
\text { Electricity }\end{array}$ & $\begin{array}{l}9 \text { Acres } \\
\$ 3.76 \times 10^{5} \\
1.39 \times 10^{5} \text { tons }\left(1.58 \times 10^{12} \mathrm{Btu}\right) \\
169 \mathrm{gal} / \mathrm{min} .(272 \mathrm{Acrc}-\mathrm{ft} .) \\
7.94 \times 10^{3} \mathrm{Alwh}\left(2.71 \times 10^{10} \mathrm{Btu}\right)\end{array}$ \\
\hline OUTPUTS & \\
\hline $\begin{array}{l}\text { Stean } \\
\text { Ferrous Hetals } \\
\text { Glass } \\
\text { Nonferrous ictals } \\
\text { Residue } \\
\text { Stack Exhaust } \\
\text { Hntor Effluent }\end{array}$ & $\begin{array}{l}3.34 \times 10^{5} \text { tons }\left(1 \times 10^{12} \text { Btu }\right) \\
9.73 \times 10^{3} \text { tons } \\
1.11 \times 10^{4} \text { tone } \\
1.39 \times 10^{3} \text { tons } \\
4.73 \times 10^{4} \text { tons } \\
4.17 \times 10^{4} \text { tons } \\
2.78 \times 10^{4} \text { tons }\end{array}$ \\
\hline
\end{tabular}

assumes no capital investment for boilers or additional air pollution equipnent. b Assumes average heat value of $11.4 \times 10^{6} \mathrm{Btu} / \mathrm{ton}$. 
waste (Holloway, 1978).

There are numerous other processes that transform MSW into a usable fuel. The Black Clawson fuel recovery process basically involves the separation of fuel from other constituents of municipal refuse by wet pulping and separation techniques used in the paper industry (General Electric Co., 1975). The resulting pulped fuel is of a very fine consistency: with about a 50 percent moisture content. No experience with extensive use of the fuel in utility boilers exists, however, all elements of the fuel preparation process have been in operation at the material recovery demonstration plant in Franklin, Ohio.

ECO-Fuel II, a cellulosic powder:obtained by the hydrolytic chemical treatment of the organic fraction of refuse can be pelleted (General Electric Co., 1975). This fuel is a denser and more stable type of material which can be more easily stored and transported. Since ECO-Fuel II is a homogeneous fuel similar to powdered coal, it can probably be used as a larger fraction of the total fuel in co-combustion: The extent to which this type of RDF can be employed in existing or new utility boilers has not been demonstrated.

The Combustion Power Corporation (PU-400 process (Menlo Park)) is a package plant designed to consume 400 tons of waste per day (Schnelle and Yamanoto, 1975). Steel, glass and aluminum are separated out, and most of the balance is burned in a fluidizing bed combustor with head recovery accomplished by using a gas turbine generator. The process is modular in nature and can be expanded to larger sites.

It is recommended that any one or all of these alternative methods for processing MSW for use as RDF be analyzed in any future characterization of solid waste conversion systems.

\section{Pyrolysis}

\section{Introduction}

Pyrolysis is a process in which organic material is decomposed at elevated temperatures in either a low oxygen or an oxygen-free environment. Unlike incineration with air, which is a highly exothermic reaction, 
pyrolysis is endothermic and requires the application of heat, either through the addition of fuels or through partial oxidation of the pryolysis reaction. Again, unlike incineration, which produces primarily carbon dioxide and water, pyrolysis produces a complex mixture of primarily combustible gases, liquids and solid char residues (Weinstein and Toro, 1976).

Pyrolysis offers several significant advantages over MSW energy recovery systens. First, either gas or liquid fuels may be directly produced by contrulling the design of the reaction vessel and the reaction temperature. Second, pyrolysis requires the addition of only small volumes of air and thus has a much smaller gaseous waste stream to deal with for emissions control. In the case of gas producing systems atmospheric emissions are almost entirely eliminated.

The major drawbacks, of pyrolysis are that the technology is still in a developmental stage and has not been demonstrated in a large plant, and that both the capital and operating costs of a pyrolysis tend to be higher than RDF systems.

The chemistry of a pyrolytic reaction is described in Appendix $H$. The product mix of this reaction is highly sensitive to the reaction temperature. Thus, the temperature of reaction is used to distinguish two general types of pyrolytic reactions: those designed to produce gaseous energy products and those designed to produce oils. The reaction temperature is adjusted to maximize the production of the desired produce (gas or oil) and, since both gas and oil are always produced in a pyrolytic reaction, the other product is consumed as an auxiliary fuel within various elements of the overall process.

Figure 3 shows the schematic flow for all pyrolysis processes. The front end systems generally include shredding and classifying and may include drying and screening prior to the pyrolysis reaction. For oil producing systems such as the Garrett Research plant at San Diego (see Appendix $\mathrm{H}$ ), gas products are drawn off following the pyrolysis reaction and used primarily as a heat source for MSW drying. These systems then depend on either partial oxidation or the use of supplemental 


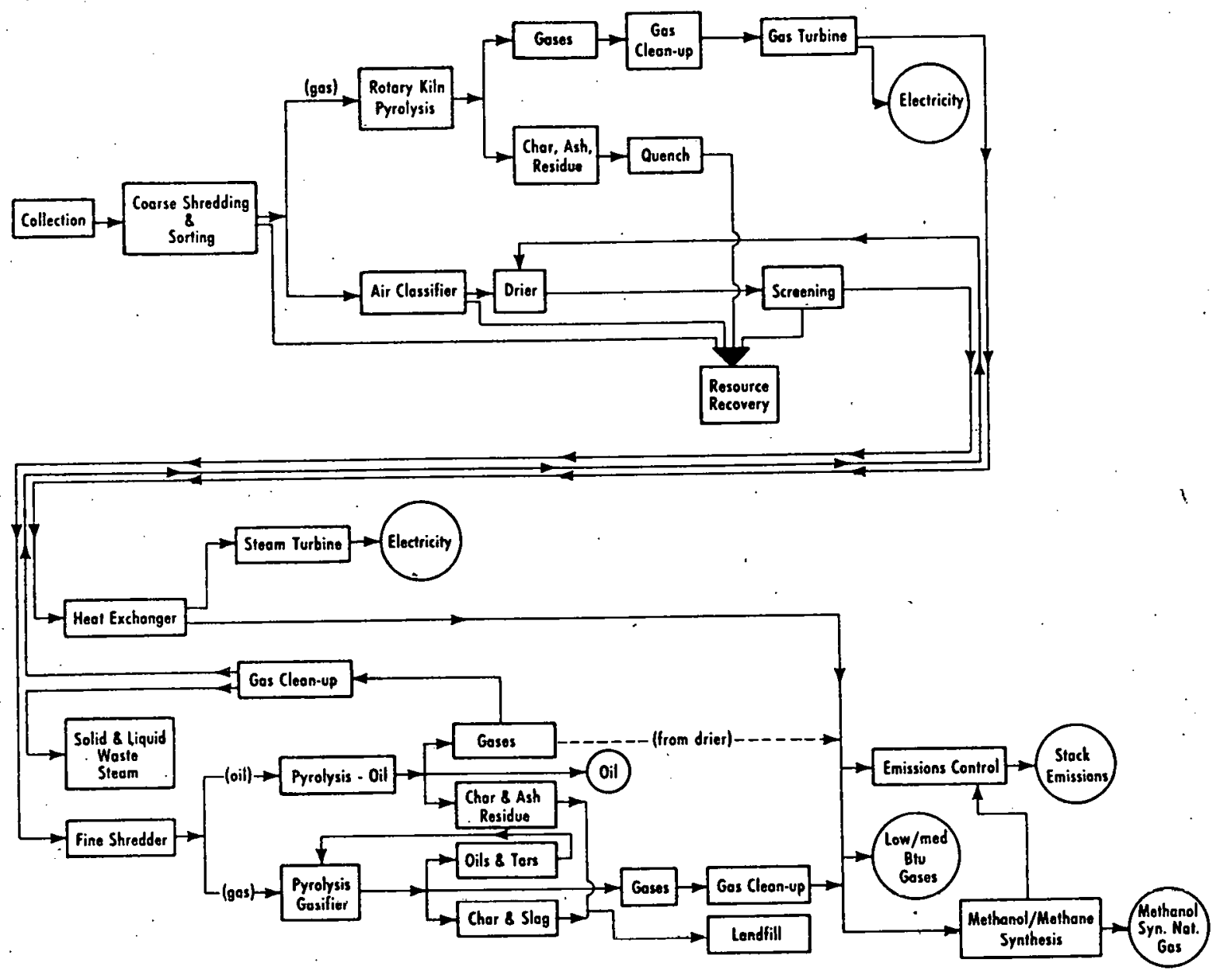

XEL $1610-11614$

Fig. 3. MSW Pyrolysis Schematic Diagram 
fuels to drive the pyrolysis process: Gas producing systems such as Union Carbide's PUROX plant, on the other hand, generally use the oil produced by pyrolysis as the fuel to drive the pyrolytic reaction and thus need no auxiliary. fuel.

While the general system described above is most representative of the current generution, systems are being tested which bypass most of the front end processes. This troe of svstem (see Monsanto's Landguard plant in Appendix $H$ ) uses only a coarse shredder before feeding the unclassified and unsorted MSW into a rotary kiln. The char from such a system contains recyclable glass and netal and is fed into the resource recovery process. The low grade off-gasses are ied into an afterburner/heat exchanger to generate steam for use in district heating. In pyrolytic oil or gas systems the basic energy product is the gas or oil itself. Conversion processes may then be used to convert this product to steam or to electricity for an end use product as required.

Actual pyrolysis systems (Purox, Torrax, Landguard and the Garrett plants) were reviewed for selection as the model application. Criteria included minimization of waste flows, proven technological feasibility, and proven economic viability. For all three cutegories the PUnOX system appeared to be the system of choice. This system has therefore been selected as the model application for the pyrolysis technology. । The Landguard and Garrett process plants are described in Appuidix II, however capital and environmental data in Appendix A are bascd exclusively on the PUROX system.

\section{Technology: Doscription}

Union Carbide's PUROX system is a high temperature $\left(3000^{\circ} \mathrm{F}\right.$ ) slagging pyrolysis process which produces a low to medium Btu gas rated as 300 to $320 \mathrm{Btu} / \mathrm{scf}$. A small test plant was completed in Mt. Vernon, New York, in 1969 and was operated over a five year test period before dismantling (Marple, 1974). Based on the success of this plant a 200 TPD prototype plant was completed in Charleston, W. Virginia in 1974 at a cost of $\$ 16$ million. Since then the plant has operated continuously except for planned upgrade and modification periods. 
As shown on the block diagram in Figure 4, the PUROX process front end system includes a coarse shredder (shredding to a maximum size of four inches) a magnetic separator for ferrous metal recovery; and an aluminum recovery process. Shredded waste is fed into the top of a vertical shaft pyrolysis furnace. As the MSW descends it is first dried by the rising hot gases and then undergoes pyrolysis at a temperature of $3000^{\circ} \mathrm{F}$ in the central portion of the furnace. The driving force in the pyrolytic reaction is pure oxygen which is injected at the bottom of the furnace to burn the char descending below the pyrolysis zone. The inert slag passing from the bottom of the furnace is quenched and sold as a glass aggregate for construction. Composition of this slag aggregate is shown in Appendix $\mathrm{H}$.

The gases rising from the furnace pass through an electrostatic precipitator, an acid neutralizer and a condenser prior to collection of the fuel gas. Ash and oil collected during this gas purification process are recycled into the pyrolysis furnace. Typical composition of the final fuel gas is shown in Appendix $H$ and the application is summarized on Technology Summary Sheet III.

The PUROX system has several important advantages over the pyrolysis systems. These include:

1. There is no air emission stream. All gases are either aqueously collected or are part of the product fuel gas:

2. The solid slag forms a fused grit which can be sold as construction or road bed aggregate.

3. Oxygen is used rather than air to drive the pyrolysis reaction. While a certain energy cost is paid to produce the oxygen, its use produces a higher heating välue gas with $\mathrm{NO}_{x}$ content.

4. All oils and sludges are recycled into the furnace so that only one waste water flow exists. In a comparison of $10 \mathrm{MSW}$ energy recovery systems conducted in 1974-1975, H. W. Schulz (1975) concluded that, from an efficiency, engineering and environmental standpoint, PUROX was the best available system. 


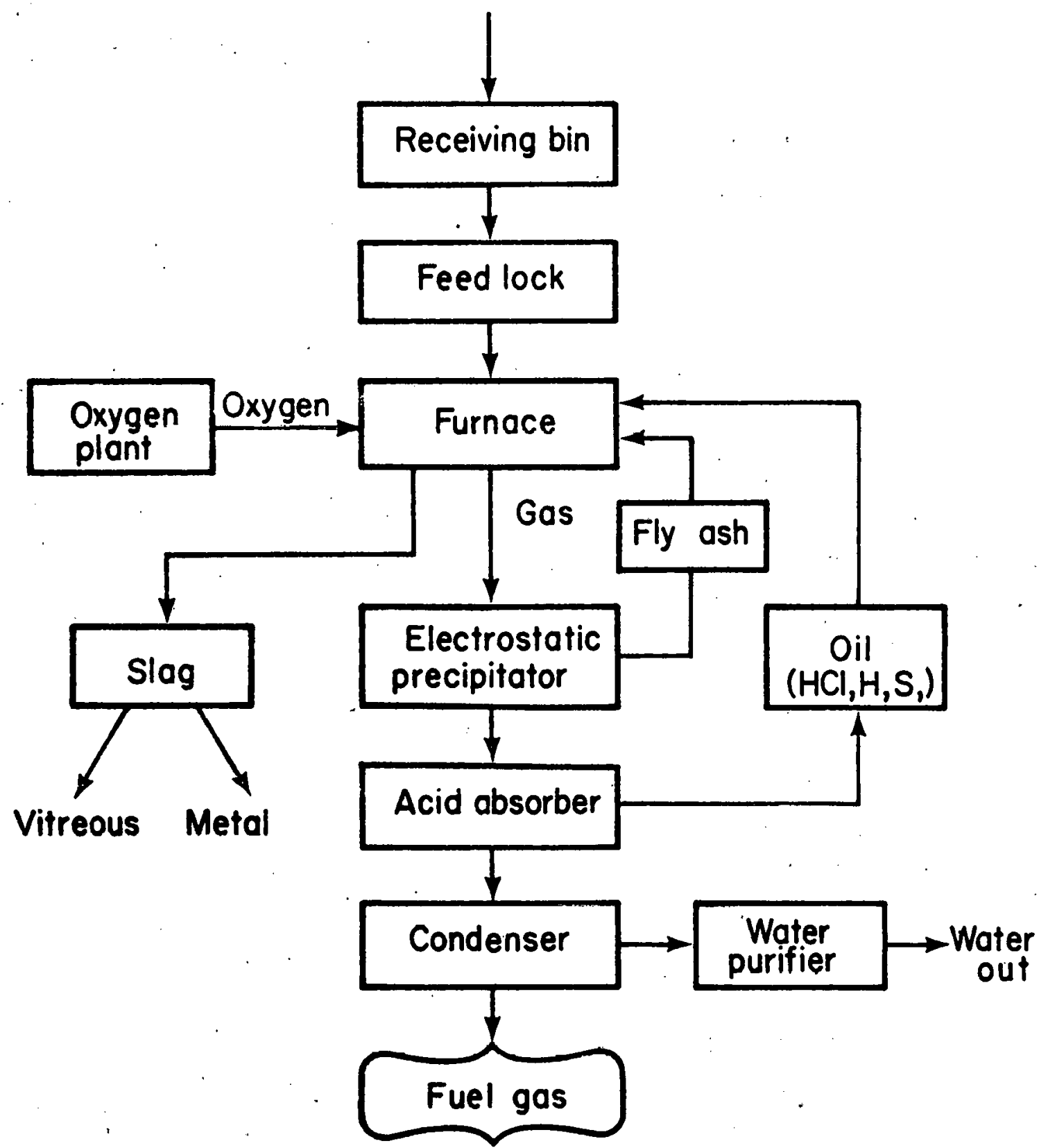

XBL $7810-11669$

F1g. 4. Flow Diagram of Uniun Carbide System 
TECHNOLOGY: Pyrolysis of MSW

DESCRIPTION: The Union Carbide PUROX system is a high temperature $\left(\sim 3000^{\circ} \mathrm{F}\right)$ oxygen enriched pyrolysis process which produces oil and low Btu gas simultaneously. By controlling the temperature of reaction at approximately $3000^{\circ} \mathrm{F}$ gas production is optimized with respect to pyrolytic oil. $0 i 1$ is fed back into the furnace to drive the pyrolytic reaction. The low Btu product gas $(\sim 300 \mathrm{Btu} / \mathrm{Scf})$ is cleaned in a two-step process prior to collection. Front end systems include shredding, magnetic separation of metalic or recoverable ferric matter, and MSW drying, which occurs as MSW enters the furnace. Several 200 TPD or smaller plants have been successfully built and operated and it is estimated that a 2000 TPD plant can be economically operated.

DESIGN SELECTION

CRITERIA: Pyrolysis was selected as a technology for characterization because the process offers several significant advantages over the other MSW energy recovery systems. First, it is a flexible system and can produce either pyrolytic oil or gas. Second, air emissions are greatly reduced over other technologies. Third, the process reduces landfill requirements below those of other systems.

The PUROX system was selected as the specific application because of the following factor: higher heating value and reduced $\mathrm{NO}_{\mathrm{X}}$ content of its process gas, the slag byproduct llas value as construction or road bed aggregate, the system has no air emissions except for the releases from the front end shredder, the residual concentrations in the waste water flow are lower than those for sevoral other pyrolysis systems, and the system has been successfully demonstrated.

END USE: $\quad$ Pyrolytic gas may either be collected and sold as a system end use product, or, as with this application, converted to electricity. 
TECHNOLOGY SUMMARY SHEET - III (continued)

RESIDUALS: While there are no air emissions other than the minor flows from the MSW shredder, waterborne residuals include $\mathrm{Hg}, \mathrm{Zn}$, $\mathrm{Pb}, \mathrm{Ni}, \mathrm{Cd}$, waste heat, solubles and sludge. Ammonia or Methanol conversion results in additional $\mathrm{CO}_{2}$, sulfur, $\mathrm{NO}_{X}$, $\mathrm{Co}, \mathrm{CH}_{3} \mathrm{OH}$. Also included are iron and fused slag. 
Due to the success of the West Virginia plant and the practicality of the process, plans are being made to expand to large scale plants. Union Carbide now projects that these plants will be made up of combinations of modular units of between 200 TPD and 300 TPD (Donegan, 1975). It is anticipated that such systems can be economically built at the 1000 TPD to 2000 TPD level. Additional front end resource recovery steps for glass and aluminum recovery may be included in these future modules.

The basic inputs to the PUROX process per ton of MSW are $120 \mathrm{Kwhr}$ of electricity and $400 \mathrm{lb} \mathrm{O}_{2}$. Major outputs include a 0.265 ton waste water flow, 0.635 tons of dry fuel gas, and 0.2 tons of slag aggregate. Total output for a 200 TPD plant is approximately $4.34 \times 10^{11}$ Btu/year. Material and energy balances for the PUROX process are shown in Appendix $H x$ (Figures $\mathrm{H}-2$ and $\mathrm{H}-3$ ).

A summary of PUROX inputs and outputs is shown in Table 5. As can be seen, the PUROX system is significantly simpler both in major funcitonal blocks and in inputs and outputs than is either the Landguard system or Garrett process; however, it is also significantly more capital intensive.

PUROX residual flows are shown in the Environmental Data section.

\section{Cogeneration systems}

\section{Introduction}

The cogeneration systems considered in this report attenpt to match the temperature of a heat supply to the demand hy using. high temperature energy which rejects heat at the temperature needed for process use. Thus cogeneration is a meanc of increasing our use of the thermodynamic potential of the fuels. we burn. This is important for both fossil fuels and waste fuels such as the wood waste and digester gas used in the systems described here. Burning such fuels to do work necessitates the use of a heat engine. Heat engine efficiency in turn is intrinsically tied to the input and output temperatures of the engine. Thus temperature determines the amount of work 
Table 5

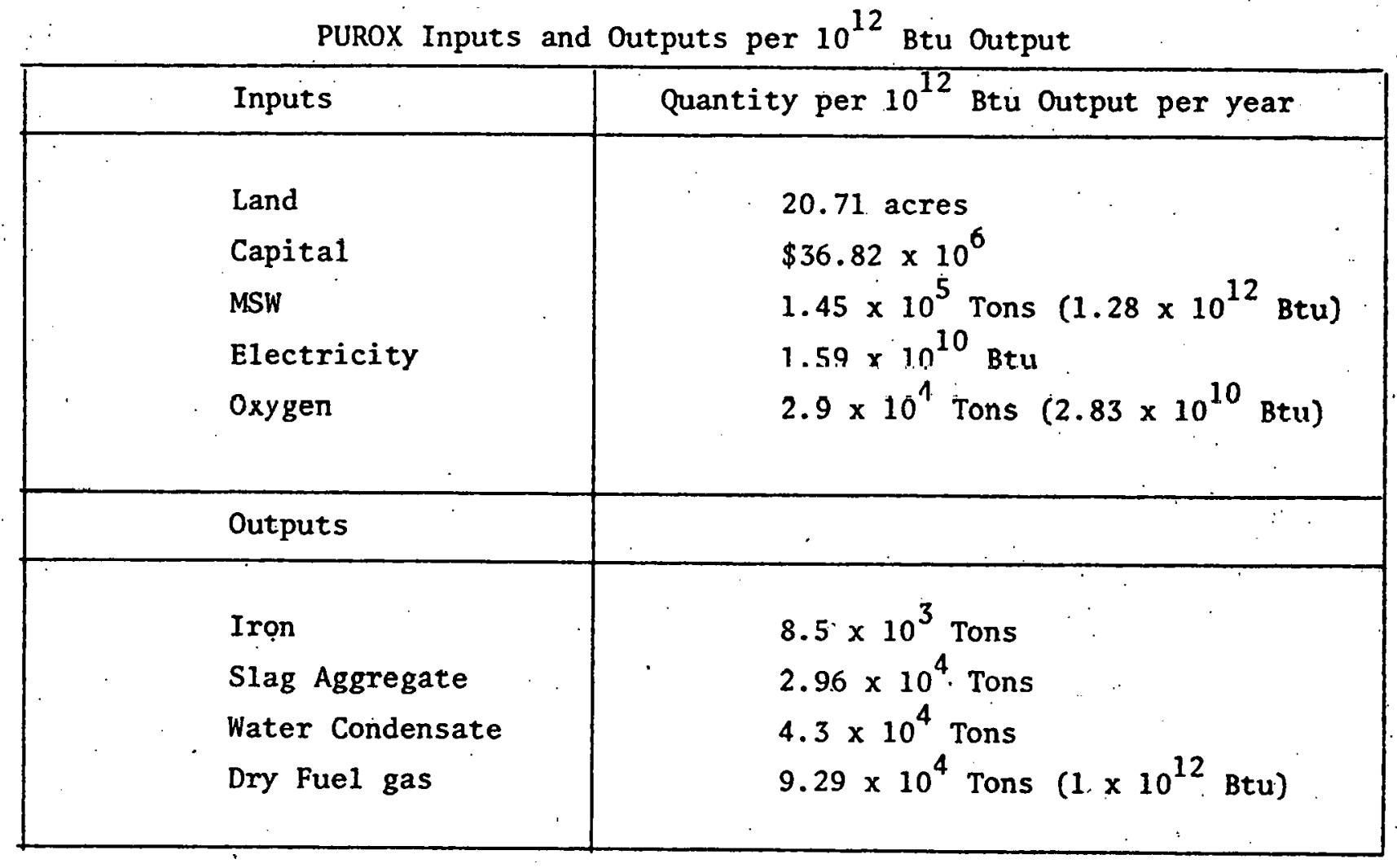


available from a Btu of heat energy. It is wasteful to lower the temperature of heat energy significantly without extracting the available work. Current status of cogeneration projects is described in Appendix D.

There are three engines of primary importance in cogeneration systems and they are all used in the applications considered in this report. They are diesel engines, combustion turbines and backpressure steam urbines. These engines, in turn, exhaust hot gas or steam at usable temperatures. The important features which were considered in the choice of systems and application were size, fuel capability, steam pressure requirements, and the ratio of power to heat produced. Details of these characteristics are presented in Appendix E.

The benefits of cogeneration are increased efficiency and decreased costs in most applications. Also cogenerated electricity at the least will reduce industrial electricity demand on utilities and in many cases will supply baseload or peaking power to the utility grid on a regular basis. This, of course, raises institutional problems with respect to the local electric utility attempting to protect its interests in the electric power business.

Finally, there are environmental issues with respect to air emissions and their location. The greater efficiency of cogeneration allows for a decrease in fuel combustion for electricity and heat taken together. Normally, however, there will be an increase in emissions at the cogeneration site which is more likely to be in an urban area than a utility power plant and for that reason the health impact mav be greater even with lower emissions.

Fluidized Bed Steam Cogeneration for the Pulp and Paper Industry

Introduction

Fluidized bed boilers for use in steam turbine cogeneration systems can be used to good advantage in pulp and paper mills because of their size scale and fuel flexibility including coal and woud wastes. The pulp and paper industry has already shown its interest and willingness for in plant generation as indicated by existing facilities. These are primarily fueled by residual oil and natural gas with only $18 \%$ of the 
energy from coal. (Therm Electron, 1966, p. 4). This proposal would elininate the consumption of oil and gas by replacement with coal and waste fuels for all electric and stcam generation. It is expected that roughly half of the fuel injut would be coal and half waste products such as bark, wood chips and spent liquor. Recently, such an example. with the Simpson Paper Company has been researched (Davis, 1978). This particular example would have a boiler capacity of $300,000 \mathrm{lb} / \mathrm{hr}$ steam at $350 \mathrm{psi}$ and $900^{\circ} \mathrm{F}$. The turbine generates $19 \mathrm{MN}$ and includes a condenser. The process steam will be extracted at $75 \mathrm{psi}$ and $175^{\circ} \mathrm{F}$. The plant has a very high load factor with a year-round average electric demand of $17 \mathrm{MN}$ and a steam demand average nf $225, \mathrm{n} n \mathrm{n} \mathrm{h} / \mathrm{hr}$. This high load factor is well matched. to the operational abilities of a stean boiler system which should not be turned on and off frequently. A particular advantage of using a fluidized bed is the ease of burning waste hog fuel which is plentiful in the area. The hog fuel costs only $\$ .50 / 10^{6}$ Btu compared to $\$ 1.50 / 10^{6}$ Btu for coal.

The primary problem that will be encountered in the implementation of this system is slowness with which fluidized bed boilers are being developed. The present American demonistration projects appear to be several years behind the level of technology and exporience boing used in Europe. This problem may be related to the small size of fluidized bed boilers which make then appropriate for cogeneration but not utility central stations. At present it apnears that 5 to 10 years will be necessary before such boilers will be offered commercially.

$\Lambda$ second institutional problem relates to the problems of selling excess electric power to the local utility. At present utility payments for such power are very low and will barely cover the fuel costs of a cogenerator.

The cogeneratiun system as described here is easily applicable to any industry needing team and having an interest in burning coal or. coal and waste fuels. Further work is needed only in the development and deployment of fluidized bed boilers ensuring proper credit for excess power sold to the utility. 
Technology description

Fluidized bed combustion is characterized by the rapid flow of combustion air upward from a gridplate through the bed material including the coal. This air flow causes great turbulence and mixing of the bed materials as if they were suspended in a turbulent liquid. In fact, it is material fluidized by air. A fortunate side effect of fluidization is the excellent mixing which promotes complete combustion even of waste materials or coal even when it constitutes on $1 y 2 \%$ of the bed material. The large amount of bed material can be limestone which in turn allows for efficient removal of $\mathrm{SO}_{2}$ as a dry solid waste. Further, the heat exchange boiler pipes can be submerged directly in fluidized bed. This allows for very good conductive heat transfer at moderate temperatures * such as $1500^{\circ} \mathrm{F}$ rather than depending on radiant heat transfer from flames at $3500^{\circ} \mathrm{F}$. This is very important in reducing the amount of nitrogen oxides created from nitrogen in the combustion air. Technology Summary Sheet - IV describes the salient features of this process.

Figure 5 illustrates the major components of the fluidized bed boiler cogeneration proposal for a pulp and paper plant. Table 6 summarizes the inputs and outputs for the fluidized bed cogeneration system.

Secondary water Treatment Plant Cogeneration Using Diesel Systems

Introduction

One application of diesel cogeneration systems using biomass involves the use by sewage treatment plants of digested sewage gas for electricity generation as well as heating and pumping. An interesting example of this is contained in the plans of the Sanitation District of Los Angeles County for a waste gas cogeneration system.

Currently the District maintains a system of 24 digestion tanks operating continuousiy. Each tank has a capacity of several hundred gallons and each is fed and drained alternately in increments over a 24 hour period. These tanks digest anerobically the primary sewage sludge of the plant, producing about $5.3 \times 10^{6}$ cubic feet of sewage gas 


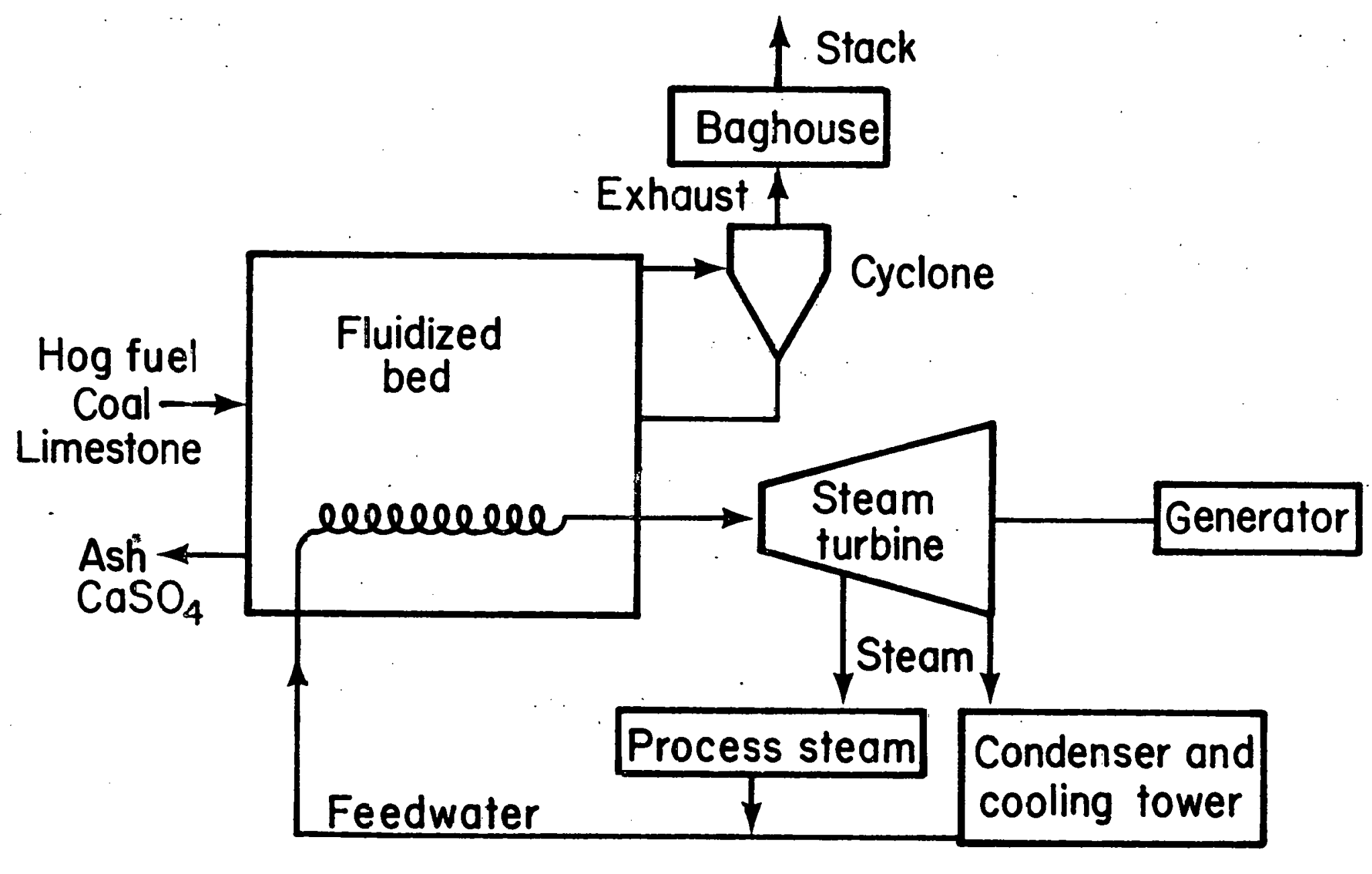

XBL 7810-11671

Fig. 5. Fluidized Bed Cogeneration for Pulp and Paper Plant 
TECHNOLOGY: Fluidized Bed Boiler

DESCRIPTION: This cogeneration system is simply comprised of a fluidized bed boiler powering a backpressure steam burbine-generator. The exhaust steam is directly usable for processes in the pulp and paper industry.

DESIGN SELECTION

CRITERIA: The fluidized bed technology was used in the pulp and paper industry application because of its ability to burn both wood wastes and coal. Also the size scale and steam pressures available were well matched.

END USE: This application was to provide the pulp and paper industry with electricity and steam. It could, however, be applied. to any industry needing low and or medium pressure steam and which can burn coal and/or waste material.

RESIDUALS: Fluidized bed boilers have low NO $_{x}$ emissions because of low temperature combustion. Sulfur dioxide is effectively controlled by limestone in the bed and particulates are very effectively controlled with the use of fabric filters. 
Table 6

Summary of Fluidized Bed Cogeneration Inputs and Outputs

\begin{tabular}{|l|l|}
\hline Parameter & Amount per $10^{12}$ Btu output/year \\
\hline INPUTS & $\$ 11.054 \times 10^{6}$ \\
Capital Cost & 4.2 Acres \\
Land & 42,000 Tons \\
Coal & 210,000 Tuns \\
Watcr Construction & $353,000 \mathrm{Hrs}$. \\
Labor - Operation & $\sim 2 \times 10^{4} \mathrm{Hrs}$. \\
& \\
OUTPUTS & 4750 Tons \\
Ash & $0.45 \times 10^{12} \mathrm{Btu}$ \\
Electricity & $0.55 \times 10^{12} \mathrm{Btu}$ \\
Steam Heat & 210,000 Tons \\
Steam Flow & \\
\hline
\end{tabular}


per day. A third of this is used by the District for heating the digestion tanks and to run the plant's pumping engines. The remainder is sold to the Fletcher Oil Company in Carson, California. The Btu content of the gas has been estimated for selling purposes and has been found to be between 500-580 Btu per cubic foot.

\section{Technology Description}

The District of Los Angeles County has developed several proposals to expand its treatment system and to implement electrical cogeneration. The plan considered here uses a diesel reciprocating engine waste heat boiler topping cycle generating $12.6 \mathrm{MW}$ and steam at a rate of $27.4 \times 10^{6} \mathrm{Btu} / \mathrm{hr}$. At this stage of the plant's operations the total electrical demand would be about $15 \mathrm{MW}$; the remaining demand would be purchased under an agreement for parallel generation with Southern California Edison Company (SCE). The District would install eight additional anerobic tanks for digesting of aerated secondary wastewater activated sludge. Total sewage gas available from both primary and secondary sludge digestion would be approximately 6.7 million standard cubic feet per day. Of this, about 35 percent would be allocated directly to meet the plant's increased heating and pumping needs. The remaining 4.4 million cubic feet, together with about 2,000 gallons per.. day of \#2 diesel pilot oil (see Figure 8) would be entirely available for cogeneration. Technology Summary Sheet $v$ presents an overview of the system.

A diesel engine system has the advantages of being able to burn low Btu fuel efficiently; some 37 percent of the waste gas's energy could be converted to electricity: The disadvantages of a diesel system is the high level of its $\mathrm{NO}_{x}$ emissions. This could cause a siting problem in the South Coast Air Basin, an area in which EPA requires that new generation facilities have pollutant offsets. Table 7 lists a summary of the system inputs and outputs. 


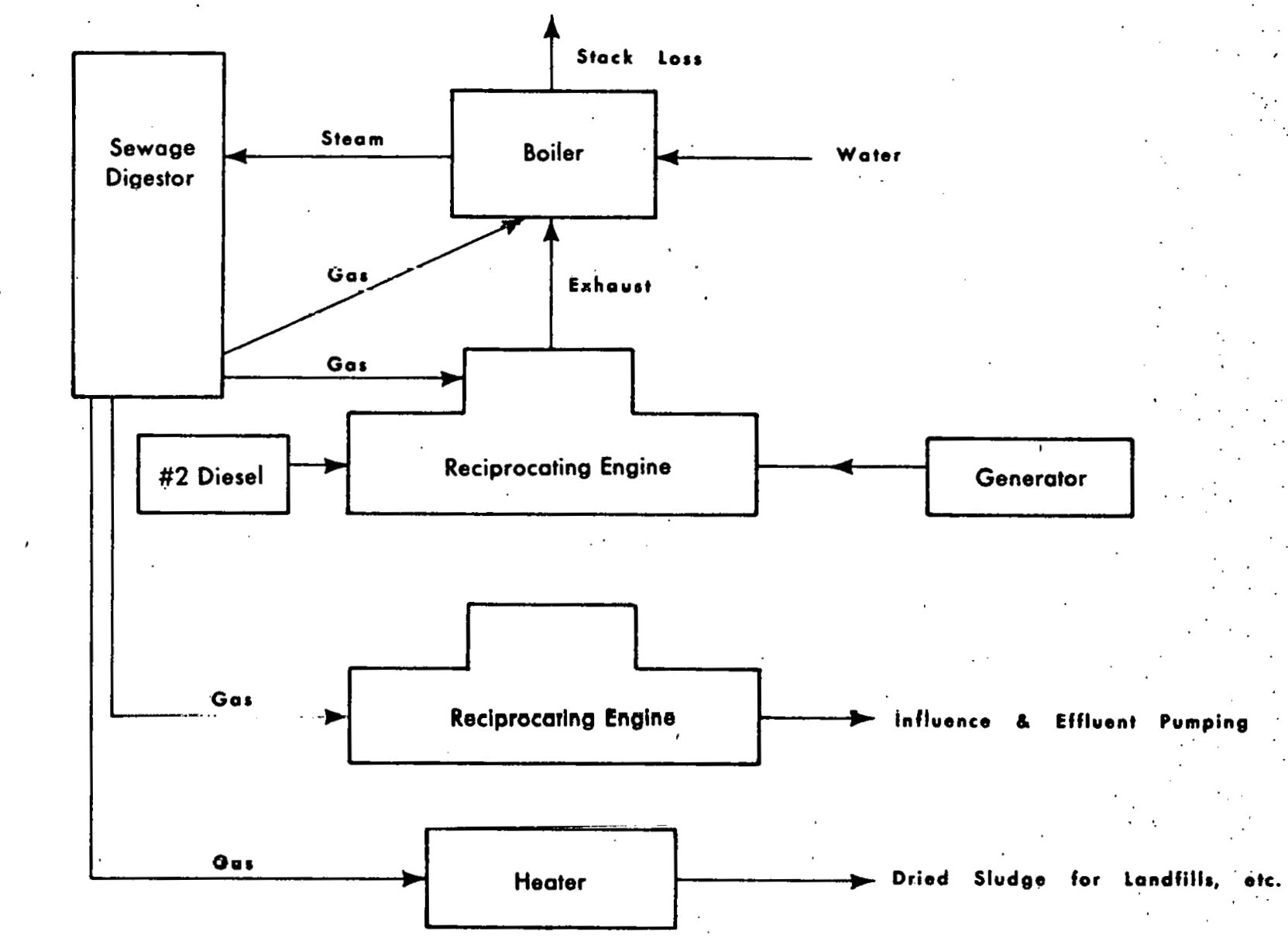

XBL $7810-1 \mid 661$

Fig. 6. Energy. Flows for Sewage Treatment Plant Cogeneration System 
TECHNOLOGY: Gas Diesel Engine

DESCRIPTION: In this cogeneration system byproduct methane gas from a sewage treatment plant is used in a reciprocating engine to generate electric power. The engine exhaust is then used to generate steam to heat the sewage digesters.

DESIGN SELECTION

CRITERIA: The diesel engine was selected for this system because of its very high efficiency in burning gas to generate a large amount of electricity.

END USE: The sewage treatment plant was chosen as an end use for this cogeneration system because of its supply of waste gas and need for low grade heat.

RESIDUALS: The primary problem with diesel emissions is $\mathrm{NO}_{\mathbf{x}}$ because of high combustion temperature. Sulfur dioxide and particulate emissions are low when burning gas. 


\section{Table 7}

Diesel Cogeneration System Input/Output Summary

Inputs

Land

Capital

\#2 Diese1 Pilot 0i1

Sewage Gas

Water

Labor - Construction Operation
Amount per $10^{12}$ Btu Energy Output per Year

0.1 Acres

$\$ 11: 54 \times 10^{6}$

$1,192,609$ Gallons

$3963.5 \times 10^{6} \mathrm{Cu}$. Ft. (581 Btu/cu.ft.) $300 \times 10^{6}$ Lbs.

$1.26 \times 10^{5}$ Hrs.

6000 Hrs:

Outputs

Electricity

Pumping

Heated sludge

Steam

Boiler Stack Iossès
178,891 MWh

20,586 MiWh

$502.8 \times 10^{12} \mathrm{Cu}$. Ft:

$300 \times 10^{6}$ Lbs:

$198,768.2 \times 10^{6}$ Btu 
Enhanced Dil Recovery

Introduction

An important petroleum industry which is becoming much more energyintensive is oil production. $0 i 1$ we 11 recovery factors are typically about one third of oil in place or less when it is tightly bound in the rocks or the oil viscosity is very high. The latter is particularly true in California where the heavy oil recovery can be tripled to about 50-60 percent by heating. This is presently being done on a large scale with high pressure steam from boilers burning high sulfur, cheap, firsttier oil to recover second-tier oil which is twice as valuable. This political economic situation discourages any switch to coal as a fuel in the near future. However, during the period 1980 to 2000, it is possible that both local crude oil and Western coal will be used efficiently in cogeneration systems to provide electricity to utilities and steam to oil fields. This would include fuel gasification for use in combustion turbines.

\section{Technology Description}

A preliminary schematic of a possible cogeneration system is given in Figure 7. The main components are an oil gasifier which fuels a combustion turbine generating electricity and hot exhaust which in turn generates steam in the heat recovery steam generator. The net electric power available to the utility grid will be $260 \mathrm{MW}$ at a very high load factor. Technology Summary Sheet - VI characterizes the system.

There are several reasons for this proposed setup. First, the fact that very high pressure steam is required meant that a combustion turbine would have to be the prime mover because backpressure steam turbines and diesel engines cannot produce high enough pressure steam. Combustion turbines, in turn, require gas or oil. fuel which for practical purposes meant oil. Then the economic factor of price controls lead to the decision to gasify low value first tier oil rather than bring in refined oil at a much higher price. This decision obviously is artificial and may not be the best in the long run. The inputs and outputs of the system are summarized in Table 8. Operational residuals for the described enhanced oil recovery system are shown in Appendix 1. Capital requirements for the system are listed in the capital residuals section of this report. 


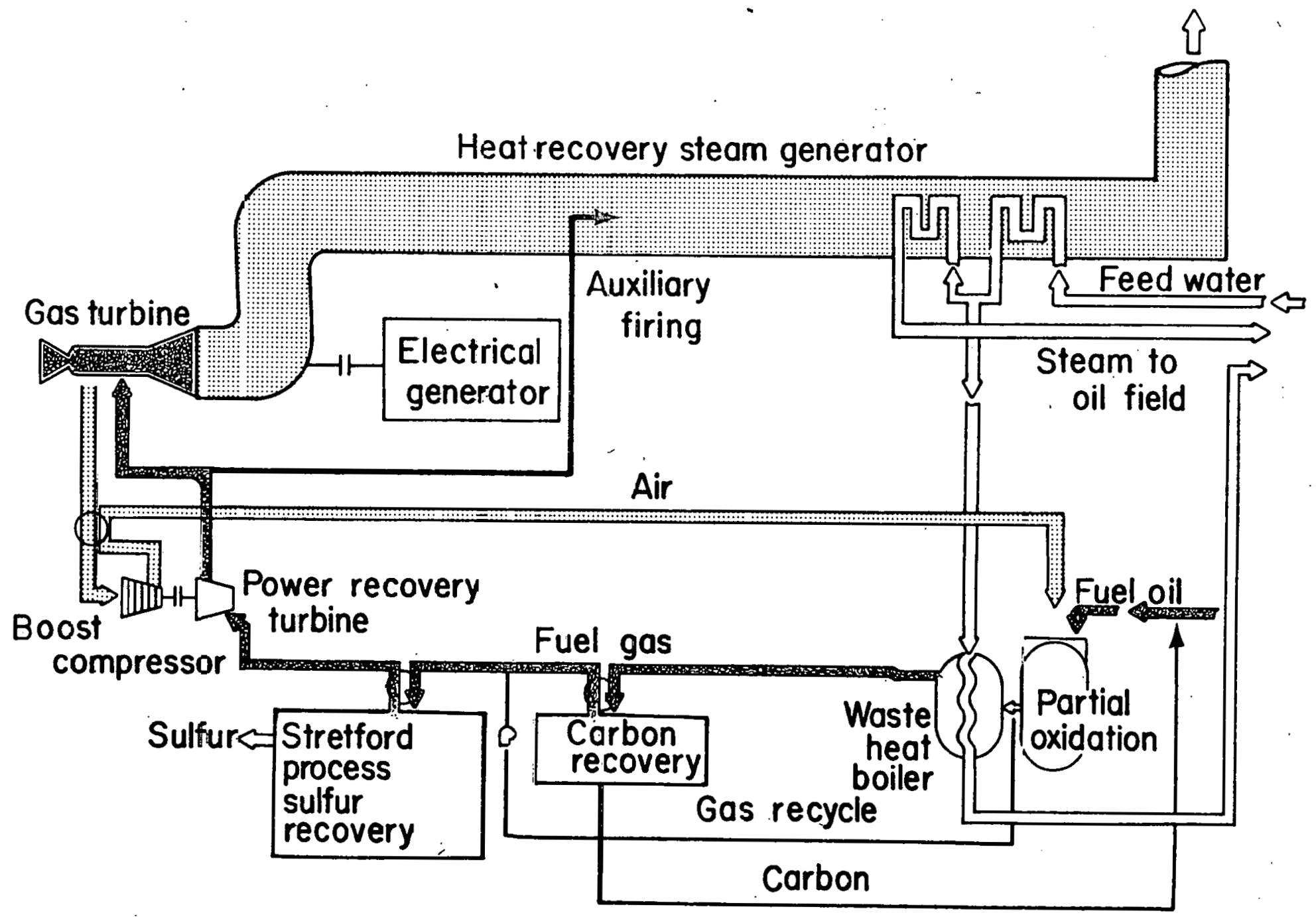

XBL $7810-11672$

Fig. 7. Thermally Enhanced Oil Recovery Cogeneration System Diagram 
TECHNOLOGY: Combustion Turbine for Enhanced Oil Recovery

DESCRIPTION: The system in this application will consist of..a Texaco crude oil gasification process which fuels three large combustion turbine-generators. The turbine exhaust is then used to raise high pressure, low quality steam in the heat recovery boiler. This steam is driven into the oil reservoir to heat and drive the heavy crude oil out.

DESIGN SELECTION

CRITERIA: Combustion turbines were the only possible choice because of the requirement for high pressure steam. The oil gasifier was chosen because of the opportunity to use artificially cheap first tier oil before it enters a refinery and requires entitlement to be paid.

END USE: Enhanced oil recovery was the chosen end use because of its requirement for high pressure steam as produced by a combustion turbine cogeneration system.

RESIDUALS: The primary residual will be $\mathrm{NO}_{x}$ from the turbine. Sulfur is removed from the gas stream and particulate emissions are low. 
Table 8

Summary of Enhanced Oil Recovery Inputs and Outputs

\begin{tabular}{|c|c|}
\hline Parameter & Amount per $10^{12} \mathrm{Btu}$ output/year \\
\hline INPUTS & negligible \\
Land & $210,000 \mathrm{bbl}$ \\
Crude oil & $\$ 16.37 \times 10^{6}$ \\
Capital & $8.38 \times 10^{6} \mathrm{Hrs}$. \\
Labor Construction & $2.7 \times 10^{3} \mathrm{Hrs}$. \\
Operation & \\
& $.25 \times 10^{12} \mathrm{Btu}$ \\
OuTrurs & $.75 \times 10^{12} \mathrm{Btu}$ \\
Electricity & $288,000 \mathrm{Tons}$ \\
Steam Heat & \\
\hline
\end{tabular}


ENVIRONMENTAL DATA

Direct Combustion

System Residuals

Direct combustion systems produce significant gaseous and waterborne wastes. Table 9 gives mean values for stack emissions from municipal incinerators. These figures assume the presence of scrubber systems and thus are lower than would be the case if data were taken in front of the scrubbers. Efficiency for scrubbers is reported to be as high as 95 percent (Walker, 1967; Ongerth and Tucker, 1970). However. lower values of 85 percent to 90 percent may be encountered in refractory wall systems due to high flue gas flow rates.

Table 10 lists waterborne residuals for major direct combustion waste water flows. It should be noted that several systems studied have essentially no flow from the quench water settling tank since a sufficient mass of water is entrained with the solid char flow out of the quench tank to avoid the necessity for direct quench water discharge. In all cases the quench water flow is small and less significant than the scrubber flow.

Land, water, labor and other capital residuals associated with a direct combustion system are listed in Appendix $A$ as are residual data in the format compatible with SEAS model input.

\section{Refuse-Derived Fue1}

Since there is little published data concerning the environmental aspects of RDF systems, this report will rely on information reported on the City of St. Louis/Union Electric demonstration plant. An evaluation of emissions from the refuse processing plant and the Union Electric refuse firing boiler was reviewed earlier (Kilgroe et al., 1976; Holloway, 19.76). For discussion purposes, the RDF system has been divided into three parts: collection and transport, processing (e.g. shredding and air classifying), and energy conversion. The latter components are emphasized below.

The residuals associated with the collection and transport of municipal refuse have been described previously (Aerospace Corporation, 1976). In that report, solid waste disposal was characterized as one 
Table 9

Direct Combustion Average Stack Effluent Characteristics ${ }^{1}$

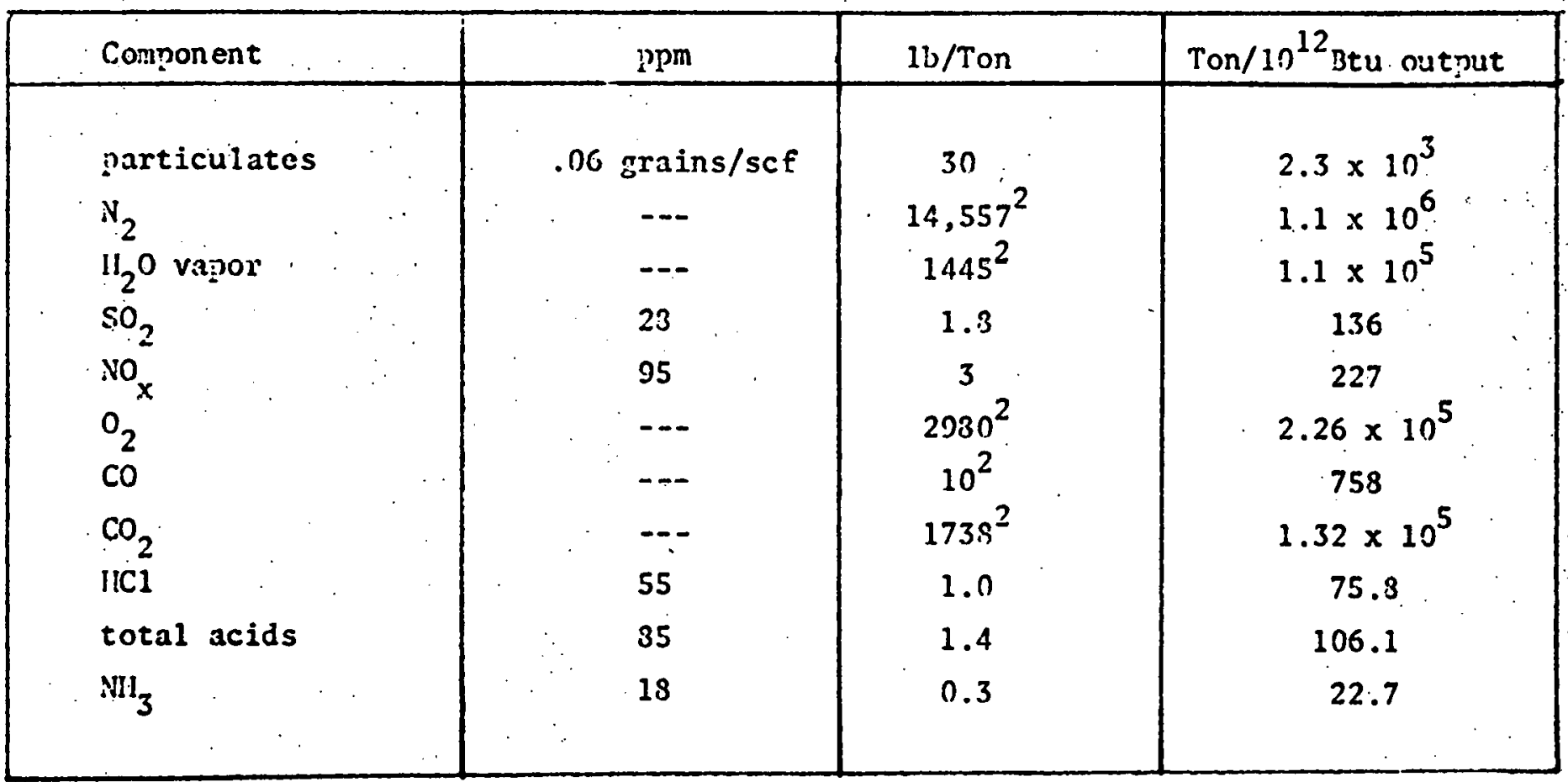

${ }^{1}$ Froin: Kaiscr, 1967; Macadam; 1976; Carotti and Smith, 1974 ;

ilalker, 1967; and :loore, 1967.

${ }^{2}$ Assume 9.6 tons excess air for combustion. 
Table 10

Direct Combustion Waterborne Reșiduals

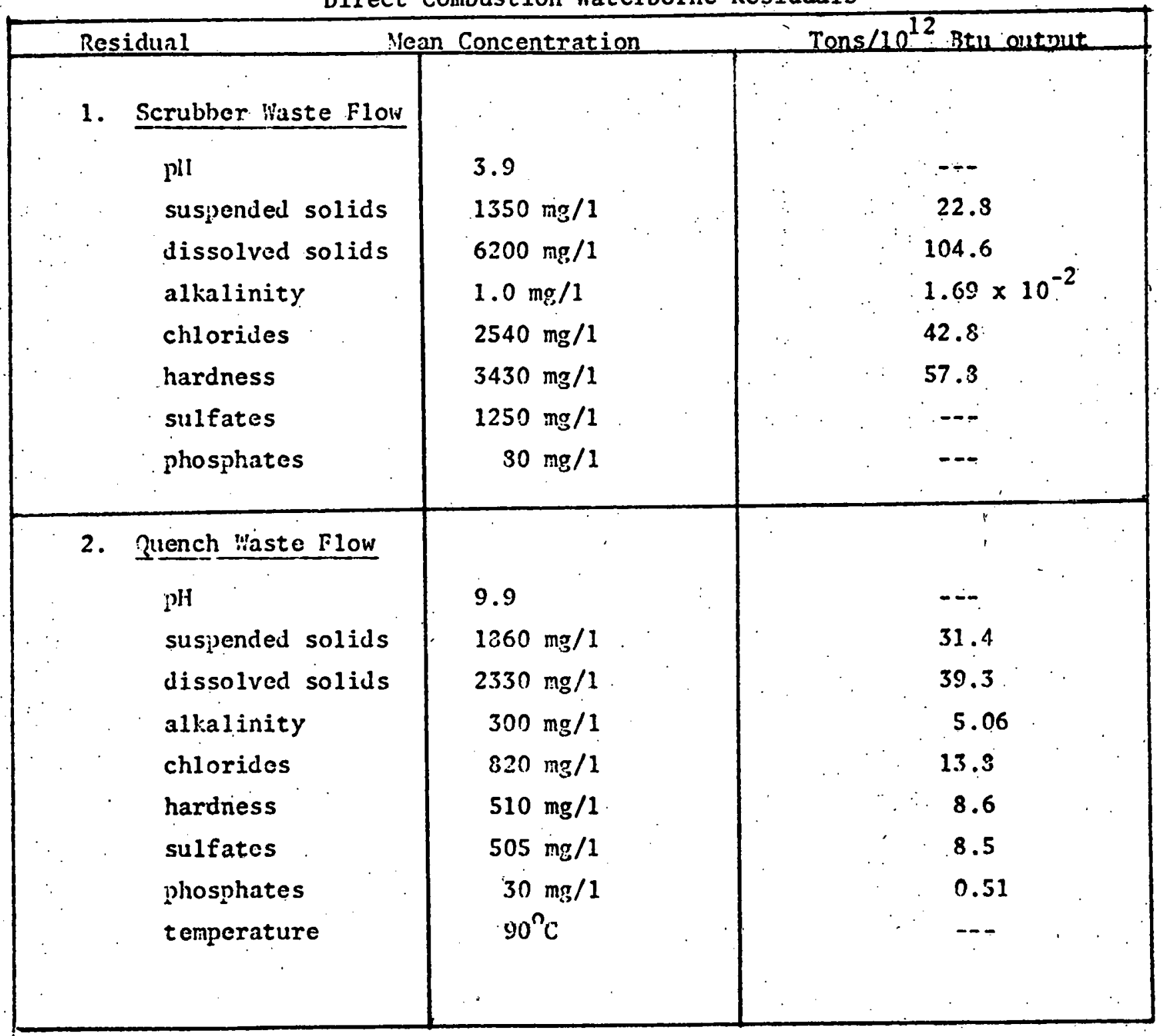

From: Ongerth and Tucker, 1970; Hann, 1970 . 
of the most hazardous occupations in the country. Statistical results show a higher than normal incidence of coronary heart disease for sanitation workers, compared to other male population groups. Carbon monoxide exposure was suggested as a possible-cause. In this report we have not calculated the residuals generated during refuse collection and delivery.

Municipal waste is received, sorted, shredded and air classified in an effort to separate recoverable materials as the organic fraction is upgraded to a usable fuel. All conversion processes essentially have the same front end operations. The major residuals during front end operations are: particulates from the hammermill (shredder) and air classification systems, noise from the processing equipment, waterborne contaminants from washdown of the waste handling area, residue for landfill and odors. In addition, bacterial and virus activities have been found in the processing plant dust (Kilgroe, 1976).

The typical particle emissions from the hammermill and air classifier were reported to be. $.032 \mathrm{~kg} /$ ton and $.346 \mathrm{~kg} /$ ton, respectively (Kilgroe, 1976). The majority of these particles (more than 90 percent) were greater than $7 \mu \mathrm{m}$ in diameter, which is larger than those normally. respired by humans. The particulates can be controlled by dust collectors.

During the energy conversion process at the power plant there are expected to be pollution problems related to the content of ash, nitrogen, sulfur and chlorine in the refuse fuel. The chemical composition of RDF determines its emission characteristics.

The boiler stack particulate emissions have been studied by various groups including the Midwest Research Institute. The particulates can be effectively collected by electrostatic precipitators (ESP). It has been reported, however, that ESP collection efficiency is reduced when RDF is co-fired with coal, which is dependent on the fuel mix (Holloway, 1976). This reduction primarily occurs at loads above 100 MWe because of the higher gas flow volumes (see Figure 8). The level of particulate emission after ESP collection (assuming 99 percent efficiency) was estimated to be 160 tons $/ 10^{12}$ Btu (Teknekron, 1975). 


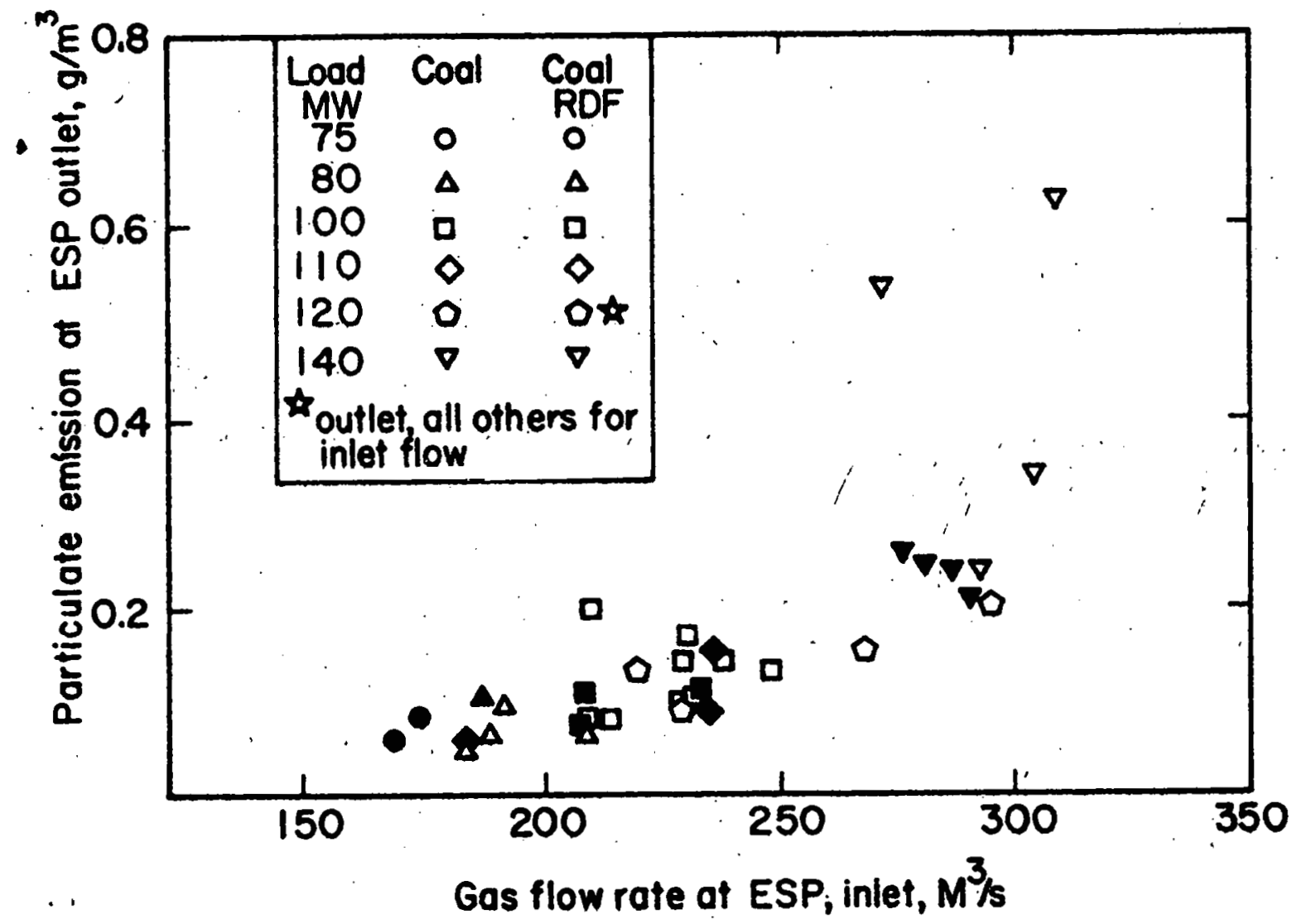

Source: Kilgroe,J.D. ef alo, 1975 XBL 7810-11677

Fig. 8. Effect of Volumetric Gas Flow Rate on Particulate Emissions 
The gaseous stack emissions have been analyzed at the St. Louis/. Union Electric Demonstration plant (Kilgroe, 1976; Klumb, 1976). Table 11 compares the data for coal only and coal/RDF firing. There is no discernible effect on $\mathrm{SO}_{2}, \mathrm{SO}_{3}$ or $\mathrm{NO}_{x}$, since the higher $\mathrm{SO}_{2}$ values in the coal/RDF system were the result of an increased sulfur content of the coal. The chlorine emissions in the stack gasses, however, are about 20 percent higher in the coal/RDF tests. The increase in chloride emissions is due to a mixture of polyvinyl chloride and cellulose products found in the processed refuse. There appears to be no data available on the release of heavy metals from the stack gas.* The flue gas residuals, resulting from a typical RDF system are presented in Table 13 .

The level of residual bottom ash was found to be significantly greater in the co-fired system than in one burning only coal at comparable boiler loads. An average boiler residue of $4350 \mathrm{~kg} / \mathrm{hr}$ was reported for the RDF system compared to $790 \mathrm{~kg} / \mathrm{hr}$ for the coal-fired system (Kilgroe, 1976). This increased level of bottom ash, which subsequently must be landfilled, consists of inert solid particles (glass, metals, etc.) and unburned solid particles (wood, plastic, leather, etc.), in addition to coal ash. The bottom ash represents about 20 percent of the boiler. residue.

Since the residue from a co-fired boiler is 4-7 times higher, a potential exists for water pollution from the boiler ash ponds that receive ash removed by water from the bottom of the furnace (Aerospace, 1976): Tests by Union Electric Company indicate that three parameters in the coal-RDF ash pond effluent do not meet state guidelines. Table 12 compares these three parameters in a coal pond and a coal-RDF pond. Other water quality parameters are higher in the coal-RDF ash pond efflucnt than the cnol ash effluent (Kilgroe et al., 1976). These include ammonia, boron, calcium, chemical oxygen demand, iron, manganese, oil and grease, and total organic solids. Sulfates, however, were significantly lower in coal-RDF ash effluent. Table 13 presents the concentration of several ash pond effluents in tons per $10^{12} \mathrm{Btu}$.

The residual emission rates for the $\mathrm{RDF}$ system in the format required for input to the SEAS model are found in Appendix A.

* Mercury will probably appear in the stack emissions (Holloway, 1976). 
Table 11

Stack Gas Ėmissions ${ }^{a}$

\begin{tabular}{|c|c|c|}
\hline Components & Coal & Coa1/RDF \\
\hline $\mathrm{SO}_{2}$ (ppin) & 943 & $1067^{b}$ \\
\hline $\mathrm{SO}_{3}(\mathrm{p})$ & 9 & 8 \\
\hline No $\mathrm{x}_{\mathrm{x}}$ (pprn) & 298 & 285 \\
\hline $\mathrm{Cl}\left(\mathrm{mg} / \mathrm{m}^{3}\right)$ & 335 & 402 \\
\hline
\end{tabular}

asource: Kilgroe, J.D., et al., 1976.

$\mathrm{b}_{13}$ percent increase in $\mathrm{SO}_{2}$ emissions during coal-RDF tests resulted from a.

24 percent increase in coal sulfur content.

Table 12

Comparison of Ash Pond Effluents ${ }^{a}$

\begin{tabular}{|c|c|c|c|}
\hline . & $\begin{array}{c}\text { Rinchemical } \\
\text { Oxygen Demand (ppm) }\end{array}$ & $\begin{array}{c}\text { Dissolved } \\
\text { Oxyģen (mg/1) }\end{array}$ & $\begin{array}{l}\text { Suspended } \\
\text { Solids (Pn) }\end{array}$ \\
\hline $\begin{array}{l}\text { Coal-RDF Pond } \\
\text { Coal Pond }\end{array}$ & $\begin{array}{c}50-100 \\
10\end{array}$ & $\begin{array}{c}3-10 \\
10-14\end{array}$ & $\begin{array}{l}10-150 \\
10-50\end{array}$ \\
\hline
\end{tabular}

${ }^{3}$ Source: Kilgroe, J.D., et al., 1976. 
Table 13

Residuals from Typical RDF System

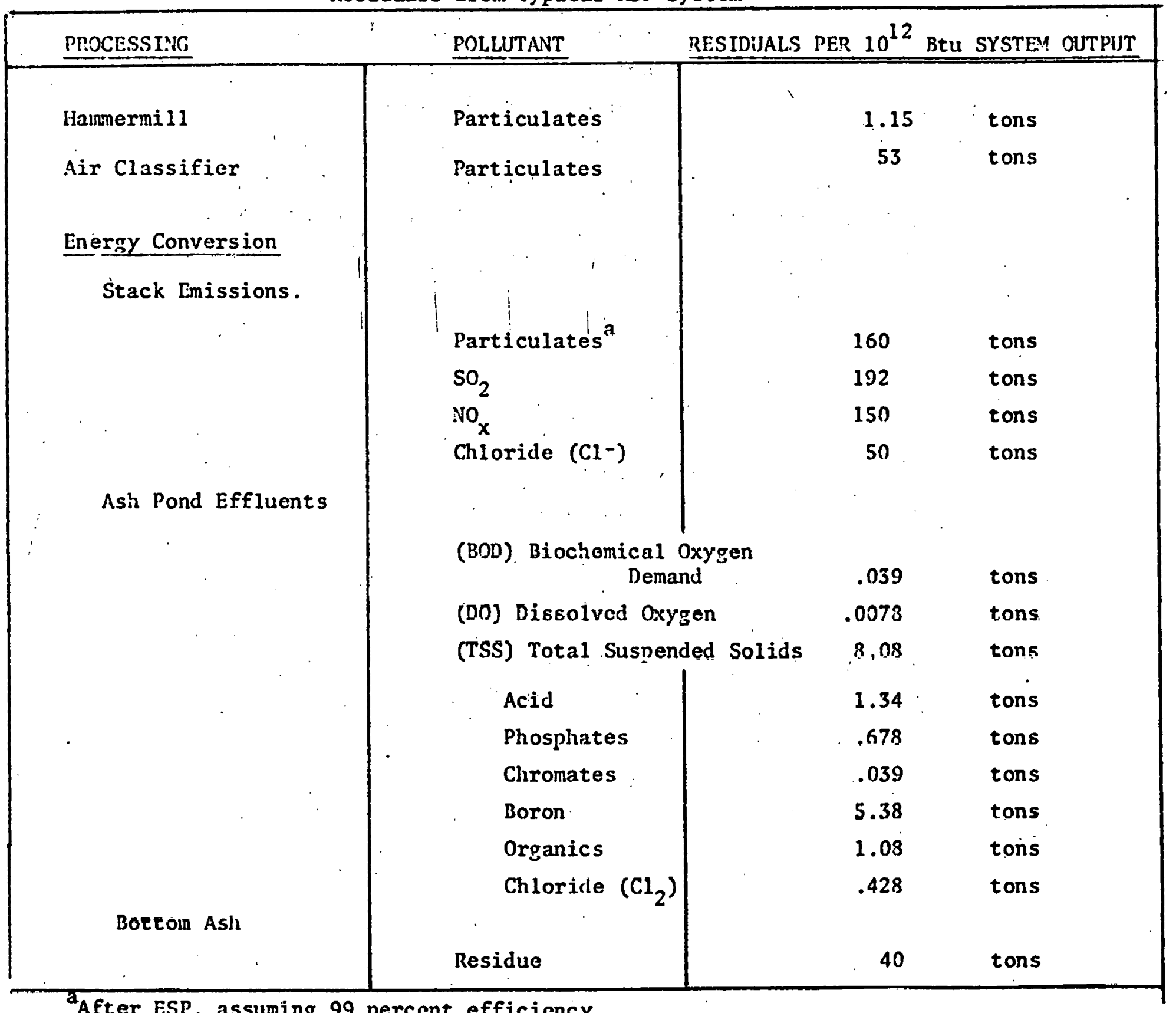

After ESP, assuming 99 percent efficiency 


\section{Pyrolysis}

Wastc flows from the PUROX process are limited to a combined scrubber and quench waste water flow and to the exhaust from the front end shredders. Oils and captured solids in the off-gas flow are recycled into the pyrolysis reaction. Solid lag residues are sold as a secondary product along with recyclable aluminum and ferrous metals. ilajor residuals associated with each of the two waste flows from the PUROX are listed in Tabie 14. Land, water and labor requirements for the system as well as capital residuals are listed elsewhere in this report. The operational residuals listed in Table 14 are also presented in Appendix $A$ on SEAS data input sheets.

\section{Cogeneration Systems}

The generation of steam and electric power is a significant use of fossil fuels and causes a large fraction of present day air pollution emissions. Cogeneration in nearly all cases is based upon the combustion of fossil fuels and so air pollution problems must be addressed. With respect to water bodies, cogeneration can significantly reduce the impact of the electrical generator because normally there will be negligible water consumption and thermal discharge beyond that normally associated with the process heat. The emission values for these pollutants aro given in Table 15 and Appendix $A$. 
Table 14

Residual Concentration for PUROX System

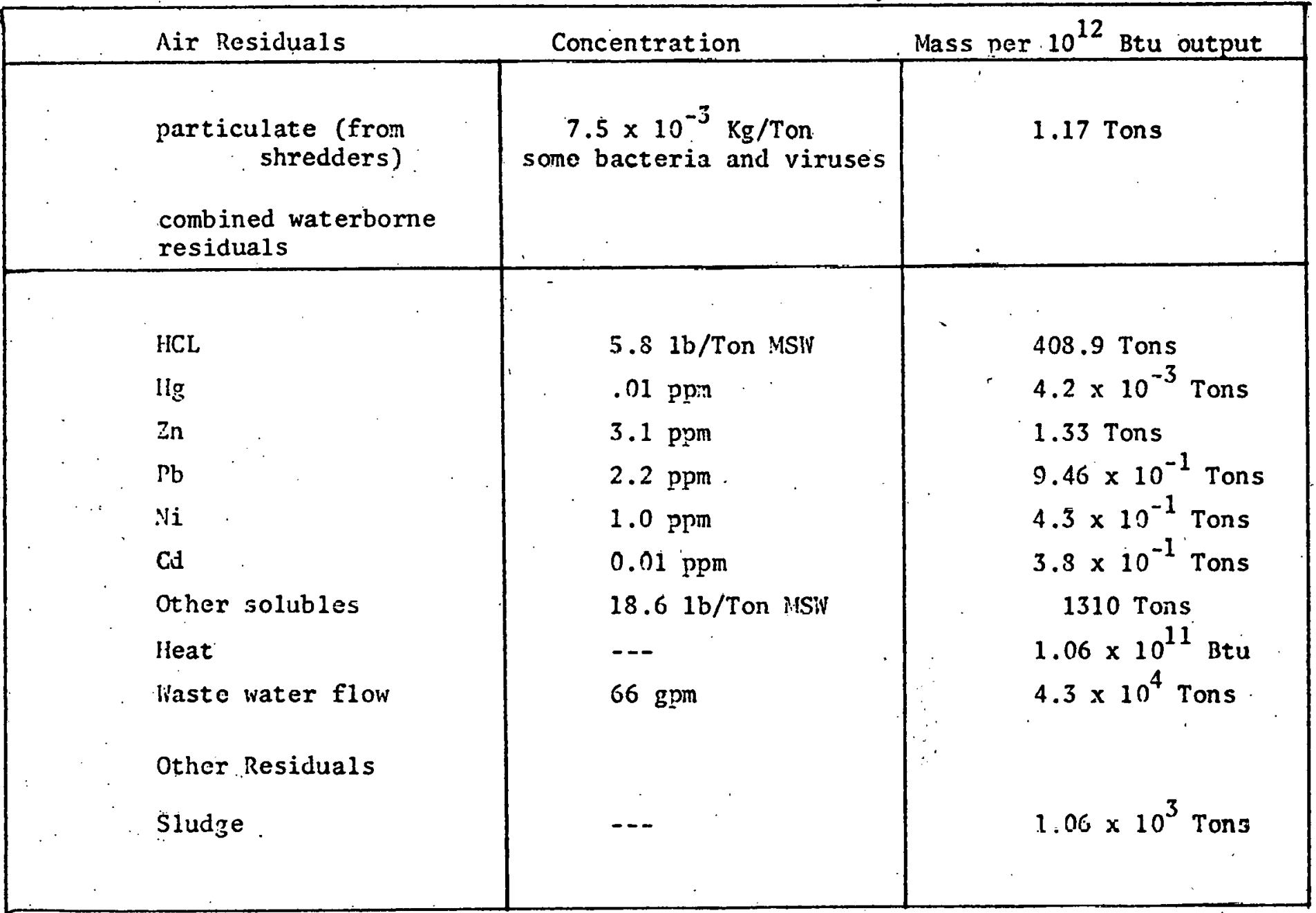


Table 15

Summary of Cogeneration Residual Generation

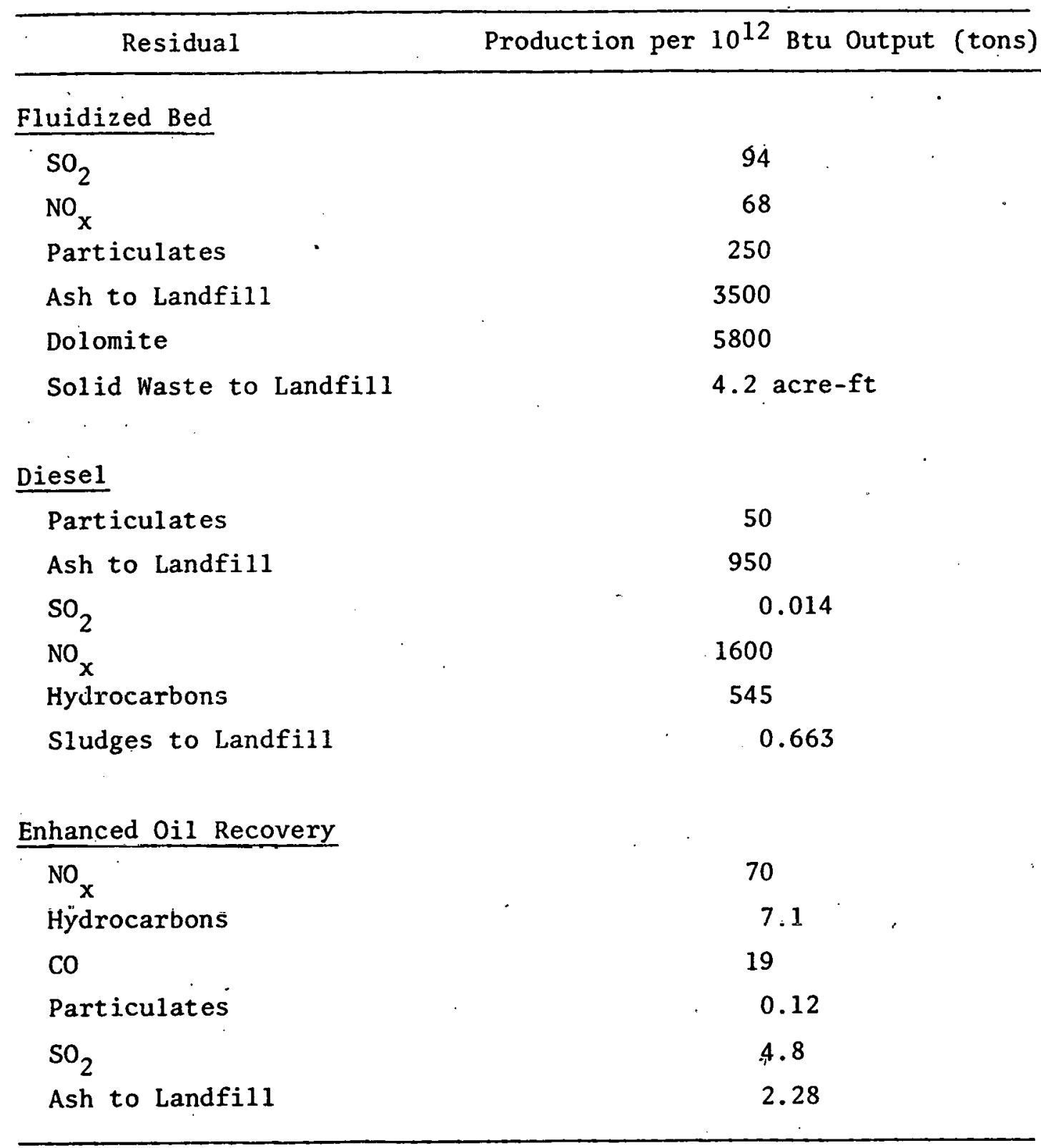


Fluidized Bed Boiler

The primary pollutants from the fluidized bed boiler for the paper plant will be $\mathrm{NO}_{x}, \mathrm{SO}_{2}$, particulates, and solid waste.

No emissions are effectively controlled in the fluidized bed by limiting the combustion temperature to $1600^{\circ} \mathrm{F}$. This is possible because the heat transfer surface is immersed in the bed.

$\mathrm{SO}_{2}$ emissions are able to be controlled with 90 percent effectiveness by absorption in the limestone bed. The spend limestone and ash mixture is then withdrawn as a dry solid waste. This in itself can be a problem because of the volumes involved. It can be mitigated by using lower sulfur fuel or regeneration.

Particulate emissions from fluidized bed boilers would be high if they were not controlled. Fortunately the controls such as a cyclone and fabric filter baghouse in series are technically simple, very reliable and flexible.

\section{Diese1 Engine}

The primary pollutant from the combustion turbine burning gas is ${ }^{\mathrm{NO}}{ }_{\mathrm{x}}$. Emissions of $\mathrm{SO}_{2}$ are avoided by removing the sulfur from the fuel gas stream which is relatively easy compared to removing sulfur from liquid fuels or flue gasses: Particulate emissions aro vcry low fö: thy englne burning gas as a fuel. The $\mathrm{NO}_{x}$ problem can be reduced by injecting steam or water into the combustion chamber of the engine, although at some efficiency cost. Note that in any case an engine burning low-Btu gas will produce less $\mathrm{NO}_{x}$ than when burning oil.

From an environmental standpoint it is unfortunate that cogeneration tends to be site-specific to industrial areas which are likely to have existing air pollution problcms. Iinding sulutions to this problem may become more difficult than overcoming the economic and institutional barriers. 
A major policy question raised by cogeneration and environmental control is the priority for clean, high quality fuel. Industries can be expected to desire high quality fuel for cogeneration systems to decrease their capital investment in fuel handling, engine cost and pollution controls. Policies which can make clean light distillate oil or natural gas available on a reliable basis will go far towards improving the economics and thus implementation of cogeneration. Because of its high energy efficiency, cogeneration can afford higher prices for fuel and economic efficiency is served by its use. Furthermore, environmental efficiency may be served by using better fuels in cogeneration systems. Particularly with gas turbines and diesel engines an industrial site may create less pollution with a clean fuel cogeneration system producing electricity and steam than would have been produced by a normal industrial boiler burning lower quality fuel. Thus environmental efficiency suggests using the best fuels in the most environmentally efficient processes such as cogeneration.

This fuel issue is very.important for two of the systems considered in this report which require oil and gas. The enhanced oil recovery cogeneration system must use oil or gas in the combustion turbine which is required for the high pressure steam needs. The sewage treatment plant burns methane in a diesel engine which directly removes that fuel from natural gas users because the gas is presently sold to the local gas utility for residential use.

Another environmental issue concerns pollutant mismatches which may prevent offset. A large cogeneration potential exists with gas turbines, which may require a ${ }^{N O} x$ offset. However, the old boilers replaced may have emitted large amounts of $\mathrm{SO}_{2}$ and particulates but little $\mathrm{NO}_{x}$. It may be difficult to control a large amount of $\mathrm{NO}_{x}$ emissions because of economic and transaction costs plus constraints on allowable offsets. A policy allowing offset credit at some ratio for other pollutants exceeding air quality standards would encourage cogeneration and lead to a greater reduction in total emissions. At present EPA policy does not allow inter-pollutant tradeoffs although there are situations where such tradeoffs would aid achievement of a heal thy air environment. The California Air Resources (CARB) but not the EPA. recognizes this and is willine to consider inter-nollutant. 
tradeoffs if the net result is a decrease in health threatening pollution. This strategy has already been accepted by CARB and Congress with respect to automotive diesel engines which are allowed to exceed the new car emission standards for $\mathrm{NO}_{x}$ because their other pollutant emissions are so low and meeting the original $\mathrm{NO}_{\mathrm{x}}$ standard would be very difficult if not impossible to attain. Diesel engines used for cogeneration are not faced with an absolute standard but the need for offset for $\mathrm{NO}_{x}$ effectively makes sitting this engine a problem or other pollution sources for offset. Thus cogeneration opportunities requiring diesel engines may be blocked. 
FACTORS INFLUENCING UTILIZATION OF SOLID WASTE CONVERSION AND COGENERATION

Several factors influence the application of any solid waste conversion project or cogeneration process. In addition to technical feasibility, reliability and economic success, there are questions of environmental quality. Will a conversion to these untested technologies merely be a trade of one type of pollution for another? In order to analyze the feasibility for solid waste conversion and cogeneration systems, it is necessary to identify their characteristics and evaluate the constraints they will place on using the fuel products. This section of the report will briefly outline a few of the major factors influencing implementation.

\section{Solid Waste Conversion}

The implementation of solid waste conversion systems depends on several factors including the supply and quantity of wastes, technical and economic feasibility and potential environmental impacts.

The residential and commercial waste stream can be subject to considerable modification in composition over a period of time. This can be an impediment to the practicality of using these resources. The central problem of MSW conversion plants is that they require a guaranteed supply of garbage for the 20-year life of the plant, in order to produce revenues to meet their high fixed capital costs.

Technologics for recovering energy from waste are developing rapidly. However, under any current technology, the major barrier to wider adoption of MSW energy recovery is greater than the value of the energy in the marketplace. The MSW energy projects operating under construction or in various stages of planning are feasible only where revenues from the recovery of secondary materials (e.g. ferrous metals, glass and aluminum) and high waste disposal fees (\$7-\$15/ton) are added to the energy, sales, thus enabling the projects to break even or show a profit (Gordian Associatcs, 1977).

The value of MSW energy products in the marketplace is closely related to the price of fossil fuels they displace and the cost of substituting the particular MSW product. To a large utility, buying MSW electricity is analogous to buying power from municipal power companies. Its production is viewed as inefficient, unreliable and a small part of the total capacity. 
Solid waste has a composition that can readily be upgraded to a valuable fuel. On its "as received" form, it has some undesirable characteristics if used as a fuel, but preparation and separation overcome most of these. The heating value of the processed product must be high enough to minimize the effect of the fuel on the boiler or furnace efficiency. Costs of transporting, storing and handling increase as the heat value decreases, since a greater amount of fuel has to be processed in order to obtain the same amount of energy. Enough of the final product must be available to justify any expenses that the user will incur in modifying the facility to accept this new fuel source.

Solid refuse can bo used as a substitute for conventional fossil fuels in existing or newly designed combustion units. The major markets are utility steam electric boilers, industrial steam and steam electric boilers, and downtown steam and chilled water distribution utilities. Since resource recovery sys tems are capital-intensive, there will continue to be a lack of confidence in their economic feasibility until the systems are fully demonstrated and developed. Technologies that work on a small scale (35 tons/day) may develop unexpected problems when applied on a large scale (1000 tons/day).

Another potential economic constraint on the use of a solid waste conversion system relates to its acceptance at tho local level. Many local governmental units when faced with the problem of disposing of solid wastes tend to use the traditional methods of landfilling rather than investigating the new possibilities of resource recovery. For example, Union Electric Company of St. Louis, which was one of the first utilities to burn processed refuse fuel in demonstration project, abandoned its operation in April 1977. The problems were cconomic and political. The voters of Missouri had adopted a proposition that prevented the utility companies from including the carrying costs for construction funds in their electric rates. That restriction, plus rising costs, made the economics of the project questionable (EPRI, 1977). 
A critical aspect of the feasibility of any resource recovery system is the quality of the products. This is true for both the secondary materials (ferrous metals, aluminum, glass) and the processed fuel. Claims to recovery materials from mixed waste have not been borne out. Only ferrous metals separation, which is a long-established technology, has proven itself in practice. The high degree of purity required by markets for use of secondary materials has been difficult to achieve once materials are contaminated with mixed garbage.

Varying composition and moisture content of the processed fuel results in emissions of great inconsistency and erratic functioning of the emission control devices (electrostatic precipitators). Even though the sulfur content of MSW is relatively low in comparison to coal, there are potential problems with particulates and heavy metals. Fuel derived from refuse, for example, contains higher levels of cadmium, lead, copper, chlorine and zinc than coal (Wentworth, 1970).

Ash residues from plants, which burn solid wastes or raw garbage, may be hazardous wastes which must be trucked to special landfills that control leachates. Water pollution problems are of concern in some pyrolysis methods as well because of the high organic content of the effluent.

Critics of solid waste conversion systems argue that solid pollution problems are being traced for air and water pollution problems. The topic of concern is the actual cost needed to meet the applicable Federal and state pollution control standards. These Federal and state emissions limitations will determine the technological and economic feasibility of compliance. Furthermore, state and local review of actions regarding new projects will determine whether a new source of emission, in fact, will be permitted to locate in a given area.

The principa 1 reason for the lack of activity in resource recovery is that the activity is risky. For most communities, the key to adoption of recovery is costs that are competitive with landfill. For the nation as a whole, this genera11y means that the public sector must be the main risk taker. Furthermore, the unique financial and revenue structure of the heavily regulated utility industry contributes to why the financial and operating risks of MSW energy recuvery arc unattractive (Gordian Associates, 1977). 
Contributing causes include inflation, high interest rates, lack of sufficient investment capital, and the likelihood that MSW investment costs will not be allowed in a utility rate base (e.g. St. Louis experience).

In order to overcome some of the barriers to the utilization of municipal refuse, there are certain emerging patterns. The future development calls for not involving the utilities directly in waste disposal problems. An intermediary is suggested instead to operate the recovery facility, collect a disposal fee, convert MSW to cncrgy, and sell the secondary materials recovered (Gordian Associates, 1977).

\section{Cogeneration}

In reality cogeneration implementation depends on technical and institutional feasibility plus economic feasibility which reflects energy efficiency. All of these variables are indirectly affected by another figure which is the ratio of power output to heat output. This, determines how much, if any, electricity will be sold to the grid. For example, a steam boiler/turbine system may produce $50 \mathrm{kWh} /$ $10^{6}$ Btu of steam heat. A gas turbine/wastc heat builer, however, produces $200 \mathrm{kWh} / 10^{6} \mathrm{Btu}$ of steam heat. This is a ratio rather than an efficiency so that while a gas turbine produces more electricity, it also produces less steam heat. The important use for this power/ heat ratio is matching energy maximizing olectrical generation if institutional arrangements allow an economic advantage from selling power. The problem at present is that utilities offer very low prices for excess power generation. All of the variables affecting cogeneration interact in a complex way to determine the best system choice as illustrated in Figure 9.

The generatiun of steam and electric power is a significant use of fossil'fuels and causes a large fraction of present day air pollution emissions. Cogeneration in nearly all cases is based upon the combustion of fossil-fuels and so air pollutiun problems must be addressed. With respect to water bodies, cogeneration can significant 1 y. reduce the impact of electrical generation because normally there will be negligible water consumption and thermal discharge beyond that normally associated with the process heat. 


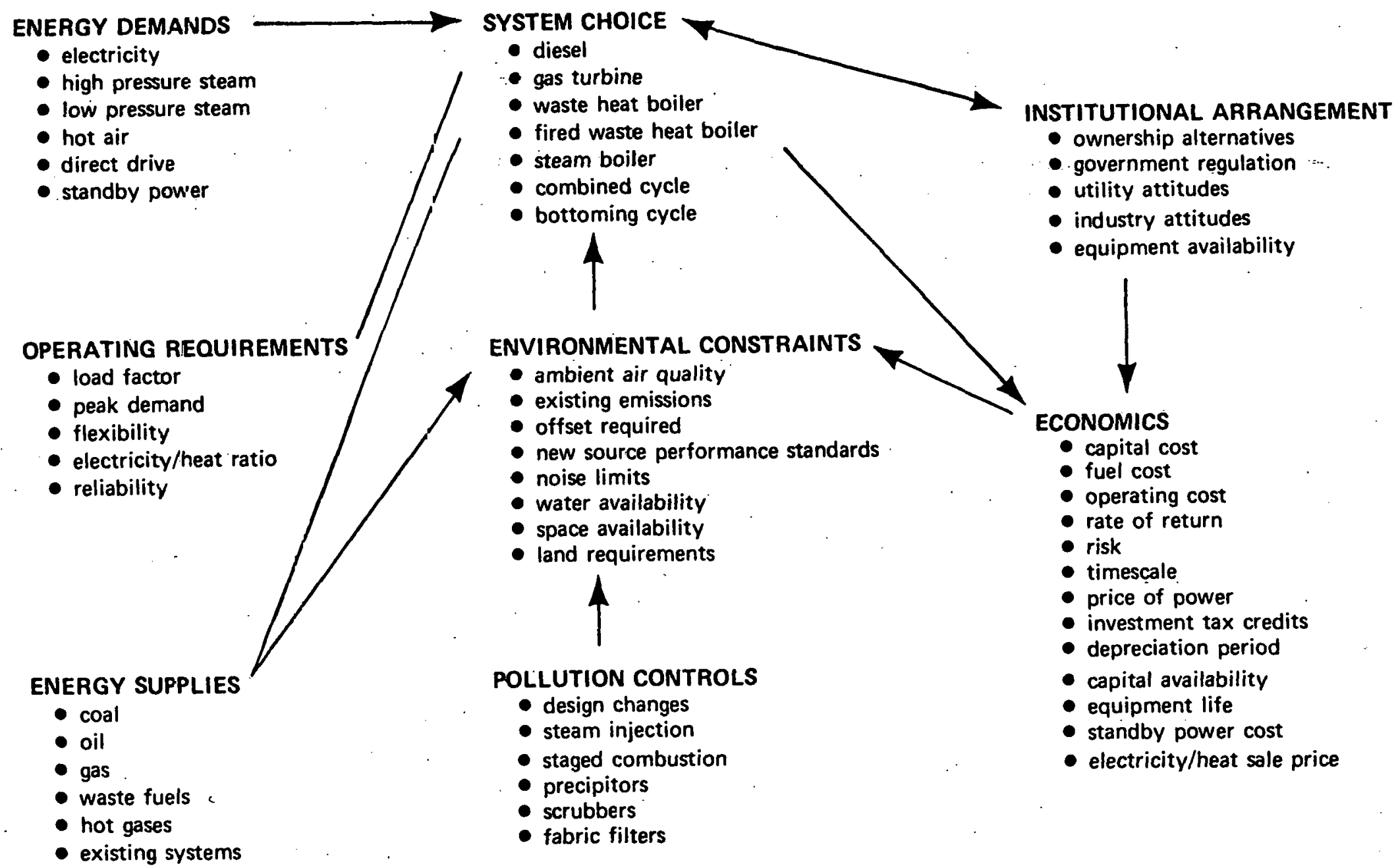

Fig. 9. Cogeneration System Alternative Analysis 
With respect to air pollution, guidelines are given in the standards and regulations established under the Clean Air Act. of first concern are the Ambient Air Quality Standards set by EPA for $\mathrm{SO}_{2}, \mathrm{NO}_{x}$ and particulates. The primary standards for these pollutants are set to protect human health. Unfortunately a large fraction of industrialized Air Quality Control Regions do not meet the standard for one or more pollutants. In these non-attainment areas new pollution sources are not allowed to interfere with meeting the standard. One compromise to prevent economic stagnation is pollution offset whereby a new stationary source can be built if a greater amount of the same pollutants are removed from the same locality. The importance. of offset to cogeneration systems is that it puts a premium on low emissions including controls stricter than New Source Performance Standards which normally apply to electrical generation. Under offset regulations each pollutant must be more than offset be decreasing or ceasing emissions elsewhere. Thus the type of emissions available for offset may be important in deciding system choice:

From an environmental standpoint it is unfortunate that cogeneration tends to be site-specific to industrial areas which are likely to have existing air pollution problems. Finding solutions to this problem may become more difficult than overcoming the economic and institutional barriers.

A major policy question raised by cogeneration and environmental control is the priority for clean, high quality fuel. Industries can be expected to desire high quality fucl for cogeneration systems to decrease their capital investment in fuel handling, engine cost and pollution controls. Policies which can make clean light distillate oil or natural gas available on a reliable basis or natural gas will go far towards improving the economics and thus implementation uf cogeneration. Because of its high energy efficiency, cogeneration can afford higher prices for fuel and economic efficiency is served by its use. Furthermore, environmental efficiency may be served by using better fuels in cogeneration systems. Particularly with gas turbines and diesel engines an industrial site may create less pollution with a clean fuel cogeneration system producing electricity and steam than would have been produced by a normal industrial boiler burning lower 
quality fuel. Thus environmental efficiency suggest using the best fuels in the most environmentally efficient process such as cogeneration. 
CONCLUSIONS

The primary environmental problems of converting municipal refuse to energy or utilizing cogeneration systems vary with the type of process employed. Several specific applications associated with MSW conversion and cogeneration have been characterized in the previous sections of this report. This section will briefly compare the various technologies according to several key parameters including system inputs, outputs, stack effluents and waterborne residuals.

Table 16 contains a cullparison of system inputs per $10^{12}$ Btu steam output. Land requirements are minimal for all systems. The RDF system is by far the cheapest to build and is also the most efficient in terms of energy recovery per ton of MSW. The fluidized bed system has the highest overall system efficiency. However, the PUROX system uses the least ancillary energy and is the only system not requiring an input water flow. Thus the RDF is the most favorable for capital inputs and the PUROX is the most favorable for operational inputs.

In Table 17 is found a similar comparison of system outputs. System energy products have becn left as the primary system product rather thàn converting each fuel to a common end use product such as electricity.

The available data on 3 taek emissions bre cumpared in Table 18. The major air pollutants of concern are: $\mathrm{SO}_{2}, \mathrm{NO}_{\mathrm{X}}, \mathrm{HCl}$, hydrocarbons, and particulates. The RDF system which was characterized in this study involved co-combustion with coal and therefore it is not surprising that the resultant $\mathrm{SO}_{2}$ levels are relatively high. The sulfur emissions, however, would be expected to be lower than those from a 100 percent cual-fired boller. Nitrogen oxides seem to be only a problem in the direct combustion system and the cogeneration applications. The diesel system associated with primary and secondary sewage treatment plants has the highest level of $\mathrm{NO}_{x}$ emissions of the processes under.study. Chlorides, in the furm of $\mathrm{HCl}$, are characteristic of solid waste conversion processes because of the presence of polyvinyl chlorides in the waste stream. Chlorides released to the air would be an effluent of some concern, since there are no emission standards as yet. . Particulates are a major component of all the systems studied. Direct Combustion 
Table 16

Systems Inputs Comparison

(amount $/ 10^{12}$ Btu stean per year)

\begin{tabular}{|c|c|c|c|c|c|c|c|c|c|}
\hline \multirow{2}{*}{ No. } & \multirow{2}{*}{ Parameter } & \multicolumn{8}{|c|}{ Systems } \\
\hline & & LG & $G P$ & $P X$ & DC & RDF & FP & DI & EO \\
\hline 1 & Land (acres) & 5.9 & 35 & 20.7 & 10.8 & 9 & 4.2 & c.1 & 0.1 \\
\hline 2 & Capital (dollars) & $11.2 \times 10^{6}$ & $7.42 \times 10^{8}$ & $36.82 \times 10^{6}$ & $48 \times 10^{6}$ & $3.76 \times 10^{5}$ & $11.05 \times 10^{6}$ & $11.54 \times 10^{7}$ & $16.4 \times 10^{7}$ \\
\hline 3 & MSW (tons) & $1.8 \times 10^{5}$ & $2.38 \times 10^{5}$ & $1.45 \times 10^{5}$ & $1.57 \times 10^{5}$ & $1.39 \times 10^{5}$ & $4.2 \times 10^{4}$ & $*$ & - \\
\hline 4 & Air (tons) & $1.78 \times 10^{5}$ & $\cdots$ & 0 & - & -- & -- & -- & -- \\
\hline 5 & $\mathrm{O}_{2}$ (tons) & $\mathbf{0}$ & 0 & $2.82 \times 10^{4}$ & 0 & 0 & -- & $\cdots$ & $\cdots$ \\
\hline 6 & Fuel oil & $1.28 \times 10^{6}$ & 567 & -- & $\cdots$ & $\cdots$ & -- & $1.19 \times 10^{6}$ & $2.1 \times 10^{5}$ \\
\hline 7 & Electricity (Btu's) & $4.05 \times 10^{10}$ & $1.14 \times 10^{11}$ & $1.6 \times 10^{10}$ & $2.94 \times 10^{10}$ & $2.71 \times 10^{10}$ & -- & -- & -- \\
\hline 8 & $\mathrm{H}_{2} \mathrm{O}$ (tons) & $1.15 \times 10^{8}$ & $9.2 \times 10^{4}$ & 0 & $1.008 \times 10^{5}$ & $1 \times 10^{3}$ & $2.1 \times 10^{5}$ & $1.5 \times 10^{5}$ & -- \\
\hline
\end{tabular}

- Landguard pyrolysis

Garrett flash pyrolysis

PX - Union Carbide Purox process

DC Direct combustion

RDF - Refuse-derived fuel

FB - Fluidized-bed cogeneratior:

DI - Diesel cogeneration

EO - Enhanced oll recovery (cogeneration)

-Coal replaces MSY

* Sewage replaces MSN $\left(3.96 \times 10^{6} \mathrm{cf}\right)$ 
Table 17

Systems Output Comparison

itons/dayilol2 Btu steam per year)

\begin{tabular}{|c|c|c|c|c|c|c|c|c|c|}
\hline \multirow{2}{*}{ No. } & \multirow{2}{*}{ Pazameter } & \multicolumn{8}{|c|}{ Systems } \\
\hline & & LG & $\mathrm{CP}$ & PX & DC & RDF & FB & $D I$ & EÓ \\
\hline 1 & Steam (tons) & $4.32 \times 10^{5}$ & $3.97 \times 10^{5}$ & 0 & $4.72 \times 10^{5}$ & $3.34 \times 10^{5}$ & $2.1 \times 10^{5}$ & $2.1 \times 10^{5}$ & 144 \\
\hline 2 & Electricity (kW-hr) & & & & & & $1.51 \times 10^{8}$ & $1.76 \times 10^{8}$ & $2.20 \times 10^{8}$ \\
\hline 3 & Fuel Oil & 0 & $4.03 \times 10^{4}$ & 0 & 0 & 0 & - & . & $\cdots$ \\
\hline 4 & Fuel Gas & 0 & $1.97 \times 10^{4}$ & $.0 .65 \times 10^{4}$ & 0 & 0 & -- & - & -- \\
\hline 5 & Ferrous Metal & $1.25 \times 10^{3}$ & $1.61 \times 10^{3}$ & $3.45 \times 10^{3}$ & $1.18 \times 10^{4}$ & $9: 73 \times 10^{3}$ & $\cdots$ & $\cdots$ & -- \\
\hline 6 & Non-Ferrous Metal & - & $1.53 \times 10^{4}$ & $1.05 \times 10^{3}$ & -- & $1.39 \times 10^{3}$ & -- & -- & -- \\
\hline 7 & Glass & $3.06 \times 10^{4}$ & $1.06 \times 10^{5}$ & $2.96 \times 10^{4}$ & $8.65 \times 10^{3}$ & $1.11 \times 10^{4}$ & -- & -- & $\cdots$ \\
\hline 8 & Waste $\mathrm{H}_{2} \mathrm{O}$ & $4.68 \times 10^{4}$ & $1.32 \times 10^{4}$ & $4.3 \times 10^{4}$ & $1.08 \times 10^{5}$ & -- & -- & $\cdots$ & -- \\
\hline 9 & Char & $1.44 \times 10^{3}$ & 35.05 & 0 & $1.73 \times 10^{4}$ & $4.75 \times 10^{4}$ & $3.5 \times 10^{3}$ & 950 & 2.28 \\
\hline 10 & Stack Ef $=$ Tuent & 585 & $1.06 \times 10^{5}$ & 1.17 & $1.63 \times 10^{6}$ & $4.17 \times 10^{4}$ & $4: 2$ & $3.15 \times 10^{3}$ & 101 \\
\hline 11 & Water Effluent & $4.68 \times 10^{9}$ & & $5.6 \times 10^{4}$ & 335.17 & $2.78 \times 10^{4}$ & -- & -- & -- \\
\hline
\end{tabular}

LG = Languard pyrolysis

FB = Fluidized-bed cogeneration

GP a Garrett flash pyrolysis

DI = Diesel cogeneration

$\mathrm{PX}=$ Union Carbide Purox pracess ...

EO = Enhanced oil recovery (cogeneration)

DC - Direct combustion

RDF : Refuse-derived fuels

olank indicates no available data 
Table 18

Stack Effluents Comparison

(tons/10l2 Btu steam per year)

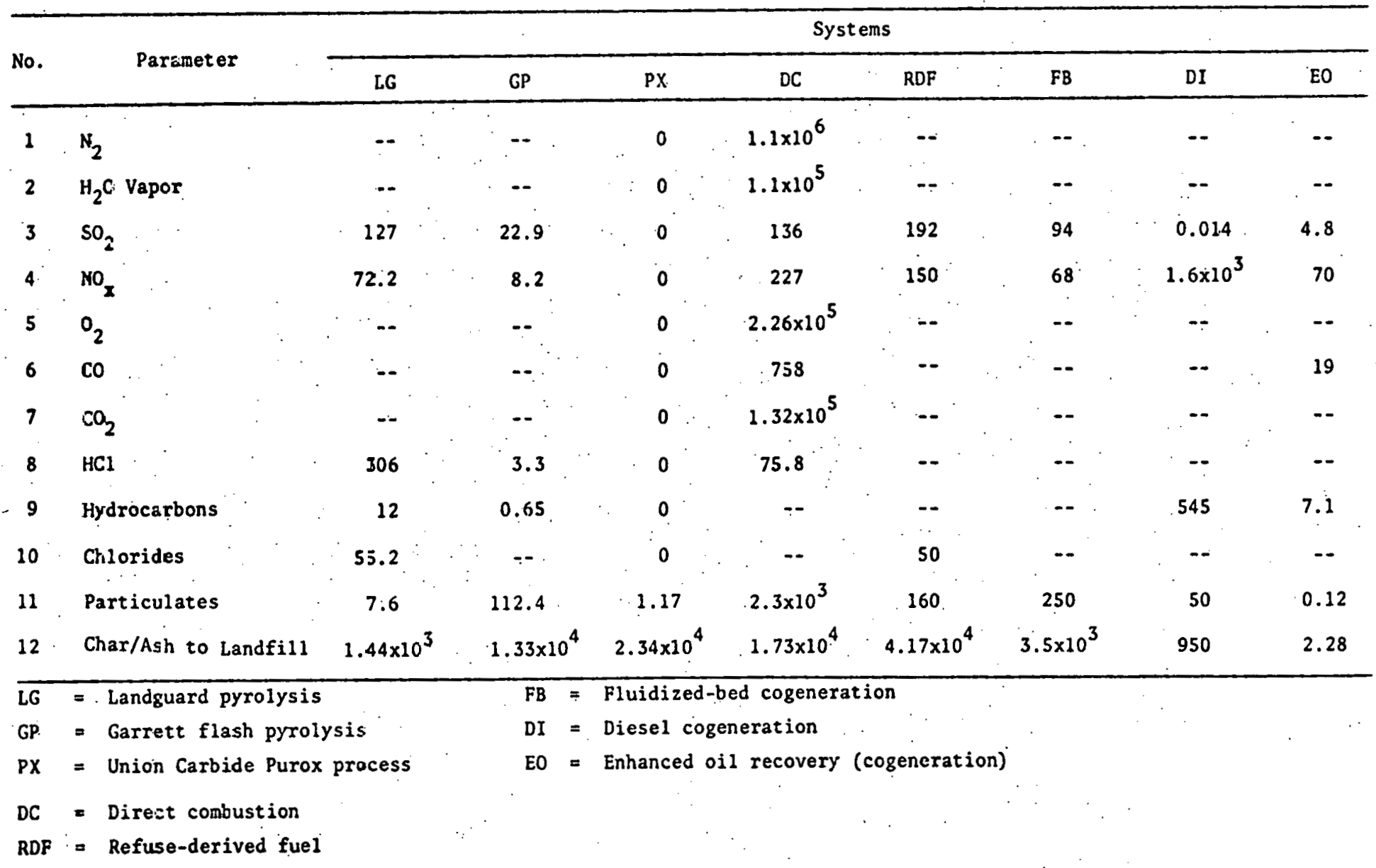


systems contribute the highest level per $10^{12}$ Btu output, wisch may limit the use of this technology in areas with strict particulate standards. There are, however, available control technologies to control this environmental concern. From the point of view of stack

- effluents, the PUROX pyrolysis system seems to contribute the lowest quantities of air pollutants, while direct combustion operations produce the highest. There are more available. data in the case of direct combustion units which may contribute to this situation. Table 19 summarizes the data on waterborne residuals. The major pollutants are: suspended solids, ash quench water, trace metals, organics and acids. Because of the paucity of information in the literature on water effluents from waste conversion and cogeneration processes, it is difficult to compare the various technologies. It is reported elsewhere that both the oxygen pyrolysis (gas utility) and flash pyrolysis (oil utility) systems produce large quantities of waste water that must be cleaned and disposed (Aerospace, 1976). The major environmental concern is the effectiveness of water pollution controls on the spread of hazardous materials.

Table 20 presents a summary of the major environmental problems for each of the systems selected for analysis. Future effort within the project will be directed toward expanding and refining the intersystem comparison as data on the various effluents become available. 
Table 19

Waterborne Residuals Comparison

(tons/10 12 Btu steam per year) ${ }^{a}$

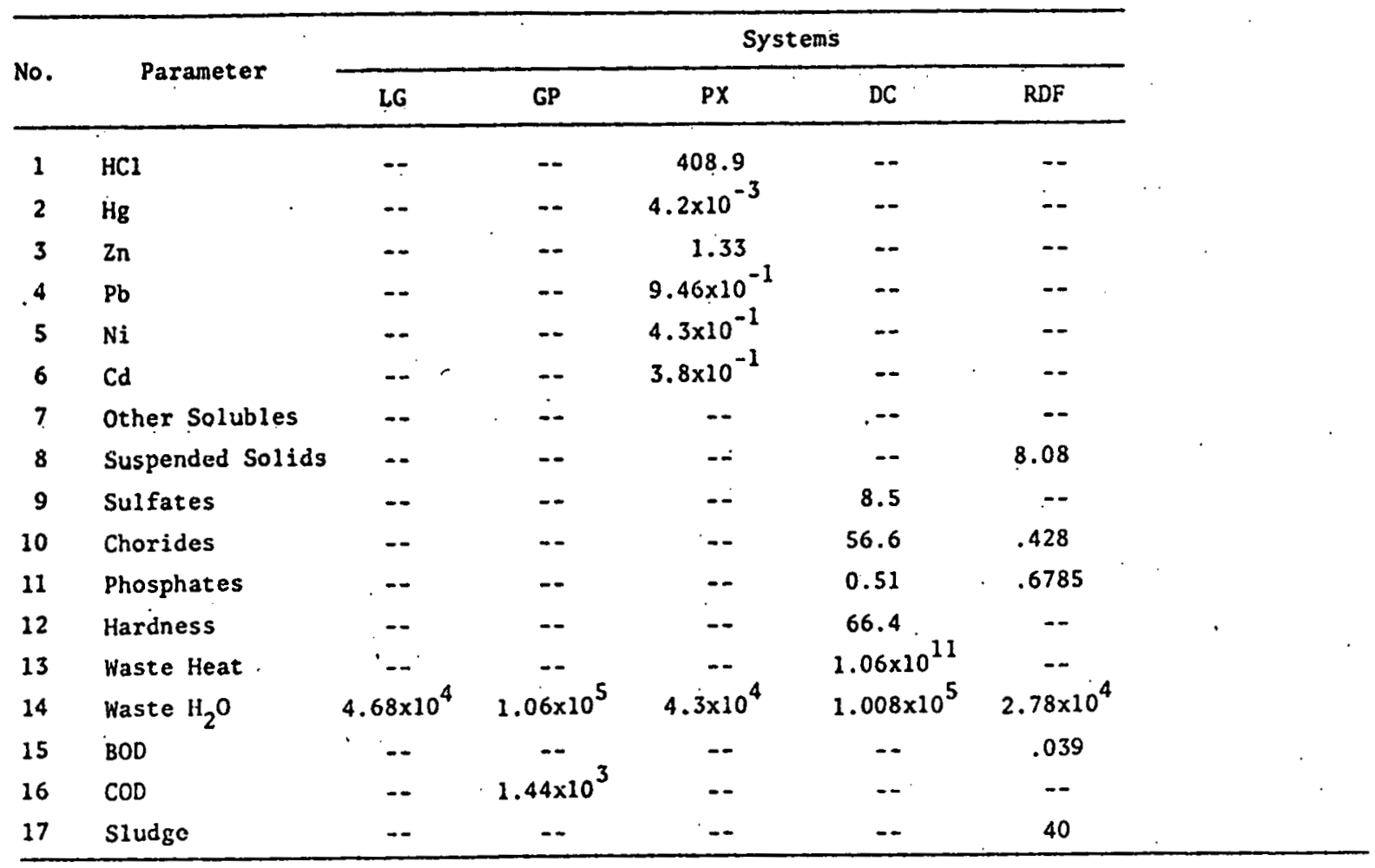

LG = Landguard pyrolysis

GP = Garrett flash pyrolysis

PX = Union Carbide Purox process

$D C=$ Direct combustion

RDF $=$ Refuse-derived fuel

"No available data on cogeneration Systems 
Table 20

Summery, of Major Environmental Problems

\begin{tabular}{|c|c|c|c|}
\hline System & Emissions to Air & $\begin{array}{l}\text { Discharges } \\
\text { to Water }\end{array}$ & Problems \\
\hline Direct Combustion & $\begin{array}{l}\text { Significant amounts of } \mathrm{SO}_{2}, \mathrm{NO}_{\mathrm{X}} \\
\mathrm{HCl} \text { and especially particulates }\end{array}$ & $\begin{array}{l}\text { Emissions } \\
\text { from ser abber } \\
\text { water }\end{array}$ & $\begin{array}{l}\text { Potential difficul- } \\
\text { ty meeting local } \\
\text { air quality stand- } \\
\text { ards }\end{array}$ \\
\hline RDF & $\begin{array}{l}\mathrm{SO}_{2} \text { (depending on } \mathrm{S} \text { content of } \\
\text { coâl), particulates, } \mathrm{HCl} \\
\therefore\end{array}$ & $\begin{array}{l}\text { Greater BOD } \\
\text { and COI levels } \\
\text { than cca- conbus- } \\
\text { tion }\end{array}$ & $\begin{array}{l}\text { Significant levels } \\
\text { of bottom ash for } \\
\text { disposal }\end{array}$ \\
\hline Purox & Particulates (from shredder) & $\begin{array}{l}\text { Significant } \\
\text { amounts of } \mathrm{HCl} \\
\text { and trace metals }\end{array}$ & : \\
\hline $\begin{array}{l}\text { Fiuidized Bed } \\
\text { (cogeneration) }\end{array}$ & $\begin{array}{l}\text { Significant amounts of } \mathrm{SO}_{2}, \\
\mathrm{NO}_{\mathrm{X}} \text { and particulates }\end{array}$ & Data not available & \\
\hline $\begin{array}{l}\text { Diesel } \\
\text { (cogeneration) }\end{array}$ & $\begin{array}{l}\text { Significant amounts of NO } x \text { and } \\
\text { hydrocarbons }\end{array}$ & Data not available & * \\
\hline $\begin{array}{l}\text { Enhanced Oil. } \\
\text { Recovery }\end{array}$ & Significant amounts of ${ }^{\mathrm{NO}} \mathrm{x}$ & Data not available & \\
\hline
\end{tabular}

* Cogeneration tends to be site-specific to industrial areas which are likely to have existing pollution probiems. 


\author{
APPENDIX A \\ CAPITAL AND OPERATIONAL RESIDUAL INPUT SHEETS \\ FOR SEAS MODEL APPLICATION
}

This appendix contains the formatted input sheets for capital and operational system residuals. For each Technology. Application, sheets are included in the following order: Capital. Expenditures and Material Requirements Summary, Reporting Form, Technology Capital Costs: Works Sheets, Technology Capital Costs: Work Sheets-Annual Operating Costs, and Residual Data Sheets:

$\mathrm{SO}_{2}$ scrubbers and either baghouses or electrostatic precipitators are included as a basic element of each system and are reflected in capital costs and in the residual generation rates. An extra column has been added onto all Capital Material Requirements Sheets. This column is used to indicate whether or not the corresponding material is recycled upon either replacement or decommissioning or is described as a land residual. It should be noted that all waste water flows described in this appendix can be discharged directly into municipal sewer systems without pretreatment.

\title{
Side Equations
}

The three MSW energy recovery processes described in this report also produce secondary products which are not sold in proportion with or to the same customers as the basic energy products. The sale of these secondary products is handled in the SEAS model system through the use of "side equations." The side equations for the MSW technologies are shown in Table $A-1$. Included in this table are both production rates for secondary equations and identification of general sectors to which these products are sold. 
Table A-1

MSN Technology Side Equations

\begin{tabular}{|c|c|c|c|}
\hline System & Prodict & $\begin{array}{c}\text { Production Rate } \\
\text { (tons } / 10^{12} \text { Btu of output) }\end{array}$ & Sectors Sold To \\
\hline \multirow[t]{2}{*}{ Direct Combustion } & Iron & $1.8 \times 10^{4}$ & $\begin{array}{l}\text { Recycled to metal fabrica- } \\
\text { tion industries }\end{array}$ \\
\hline & Glass & $8.65 \times 10^{3}$ & $\begin{array}{l}\text { Recycled to stone, glass, } \\
\text { clay industries }\end{array}$ \\
\hline \multirow[t]{3}{*}{ RDF } & Iron & $9.73 \times 10^{3}$ & $\begin{array}{l}\text { Recycled to metal fabrica- } \\
\text { tion industries }\end{array}$ \\
\hline & Aluminum & $1.39 \times 10^{3}$ & $\begin{array}{l}\text { Recycled to Non-Ferrous } \\
\text { Metal Industries }\end{array}$ \\
\hline & Glass & $1.11 \times 10^{4}$ & $\begin{array}{l}\text { Recycled to stone, glass, } \\
\text { clay industries }\end{array}$ \\
\hline \multirow[t]{3}{*}{ Pyrolys is } & Iron & $8.45 \times 10^{3}$ & $\begin{array}{l}\text { Recycled to metal fabrica- } \\
\text { tion industries }\end{array}$ \\
\hline & Aluminum & $1.41 \times 10^{3}$ & $\begin{array}{l}\text { Recycled to non-ferrous } \\
\text { metal industries }\end{array}$ \\
\hline & Glass Aggregate & $2.34 \times 10^{4}$ & $\begin{array}{l}\text { Sold for construction and } \\
\text { road jed aggregate }\end{array}$ \\
\hline
\end{tabular}


CAPITAL EXPE!!DITUPES AY!D MATERIALS REQUIREMENTS

SU'ÜLARY REPORTING FORH

TECHINOLOGY Municival SOLId Waste
APPLICATION RDF
DATE SUBMITTED $\frac{8 \text { August 1978 }}{\text { SUBMITTED BY }}$

SUBMITTED BY

A. Capital costs

1. MATERIALS

2. TRANSPORTATION

$\$ 71,952.800$

3. CONSTRUCTION LABOR

$6,150,000$

4. PROFIT \& OVERHEAD

A.I TOTAL

B. Anhual System $10^{12}$ bTU OUtput

C. Ankual System fossil fuel Equivalent/1012 Btll Output

D. Total Capital Cost/10 12 annual bTU $\left[\frac{A .1}{b}\right]$

E. ilur:ber of Years to Construct Facility NATIONAL: $x$

FEDERAL REGION NOS. nII

STATES: al1

F. Phasing of Construction Costs (\$ each year):

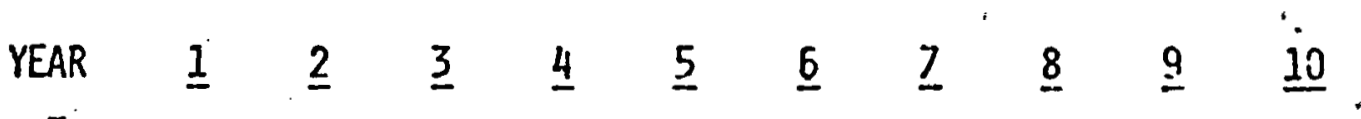

$$
\% \quad 20 \quad 20 \quad \underline{20} \quad \underline{20} \quad \underline{20} \quad-\quad-\quad-
$$

G. Expected Life of Facility (years)

h. Man Years to Construct Facilitity

1. Han Years $/ 10^{12}$ btu annual output $\left[\frac{H}{B}\right]$

30

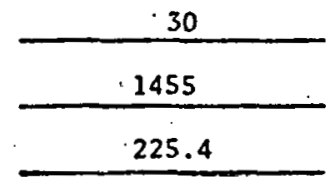

J. Estimated Land Use 
TEGE:OLOCY CAPITAL COSTS: hORK SIEET

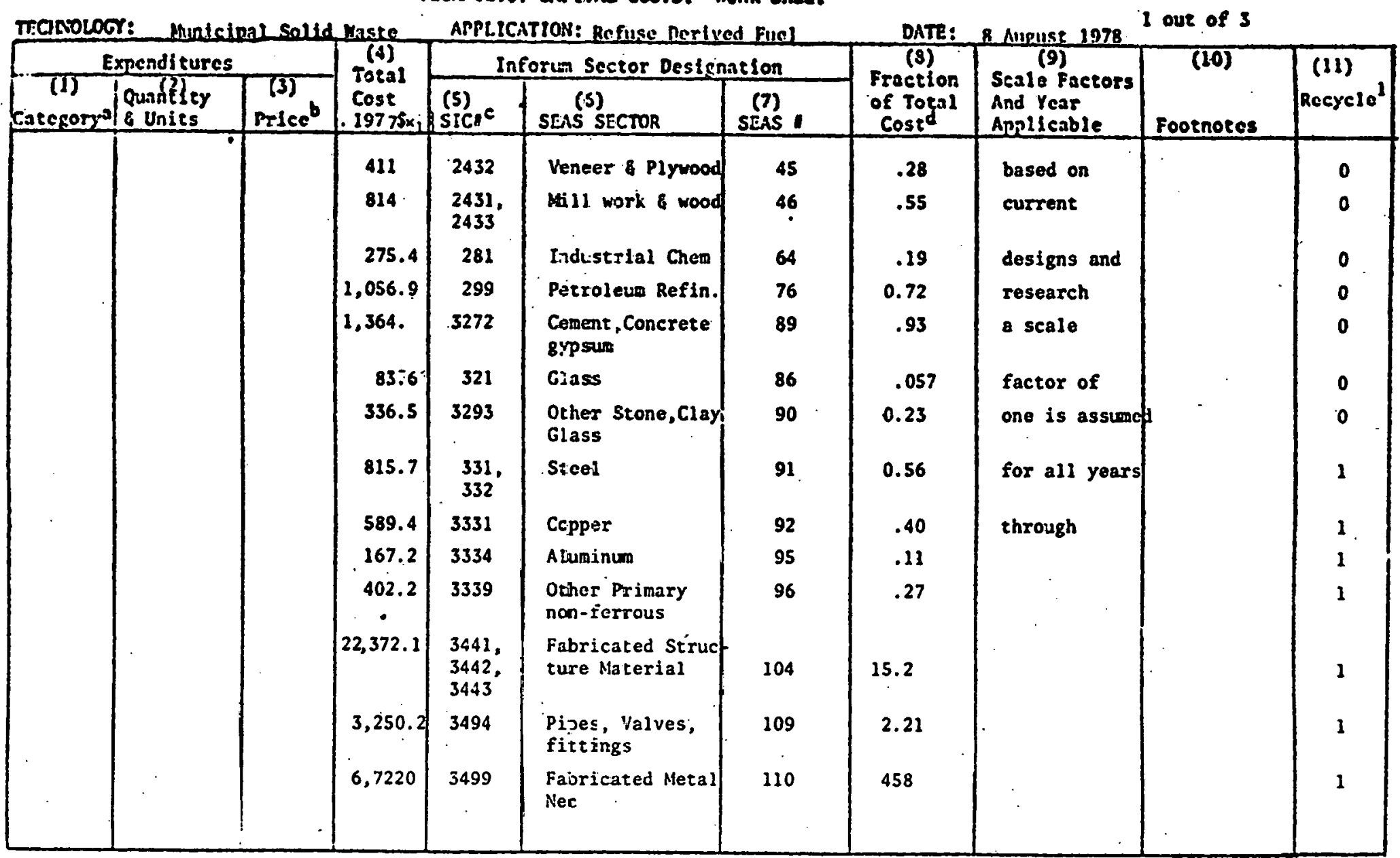

(a) For construction category, indicate the number of man-hours of labor required. (b) Prices shou:d be for 1972. If other prices are used, indicate year. (c) 1957 SIC code. (d) Numbers may not add to totals due to rounding.

1

1 yes, $2=$ no. Those items not recycled become land residuals, quantities of recycled materials per

$10^{12}$ annual Btu output are contained in the list of side equations. 
TECIE:OLOOY CAPITAL COSTS: HORK SIIEET APPLICATION: efuse Derived Fuel

2 out of 3

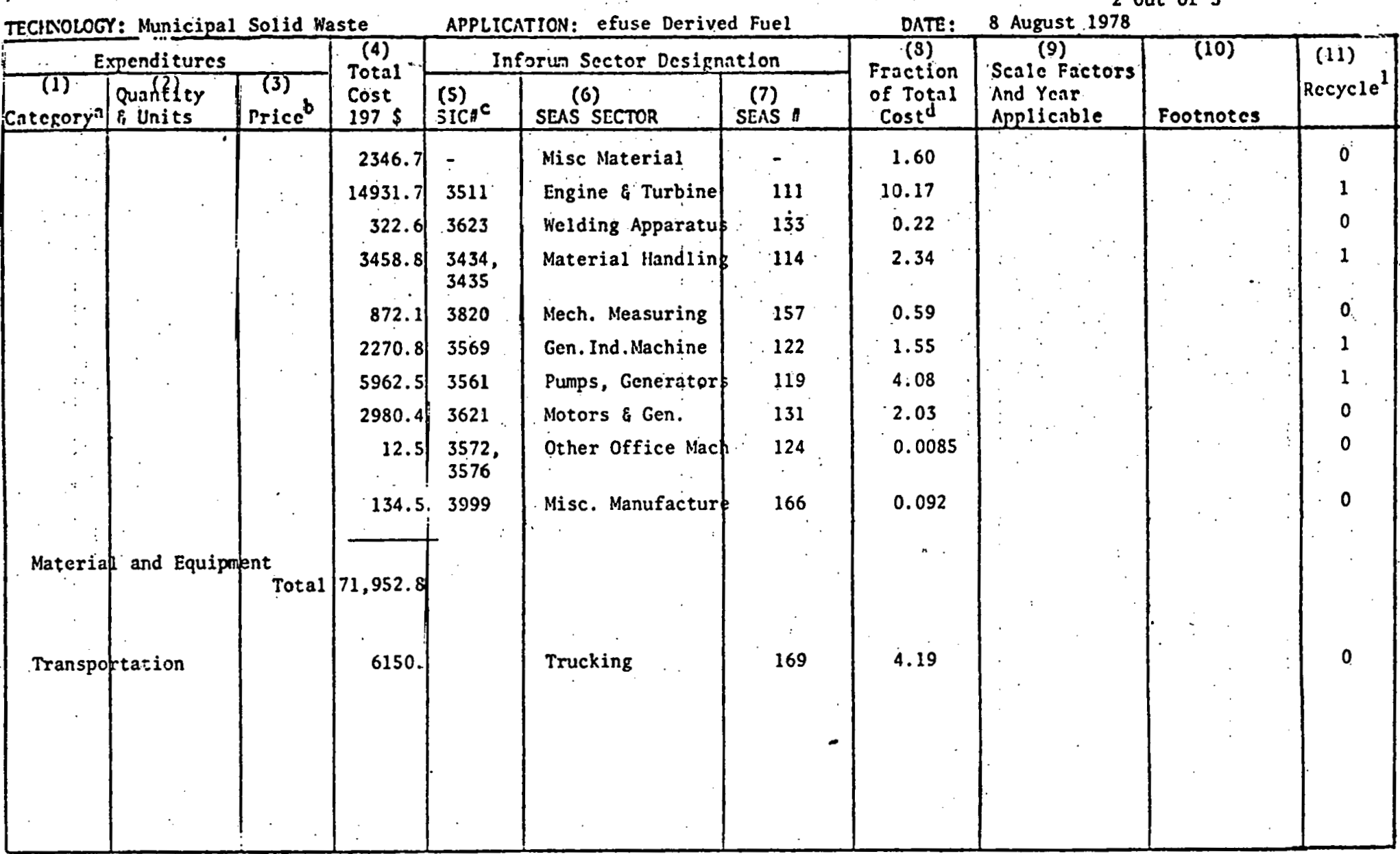

(a) For construction category, indicate the number of man-hours of labor required. (b) Prices should be for 1972. If other prices are used, Indicate year. (c) 1967 SIC code. (d) Numisers may not add to totals due to rounding.

11 jyes, 2 = no. Those itens not recycled become land residuals, quantitics of. recycled materials per 1012 annual Btu output are contained in the list of side equations. 
TECINOLOOY CAPITAL COSTS: hORX SIEET

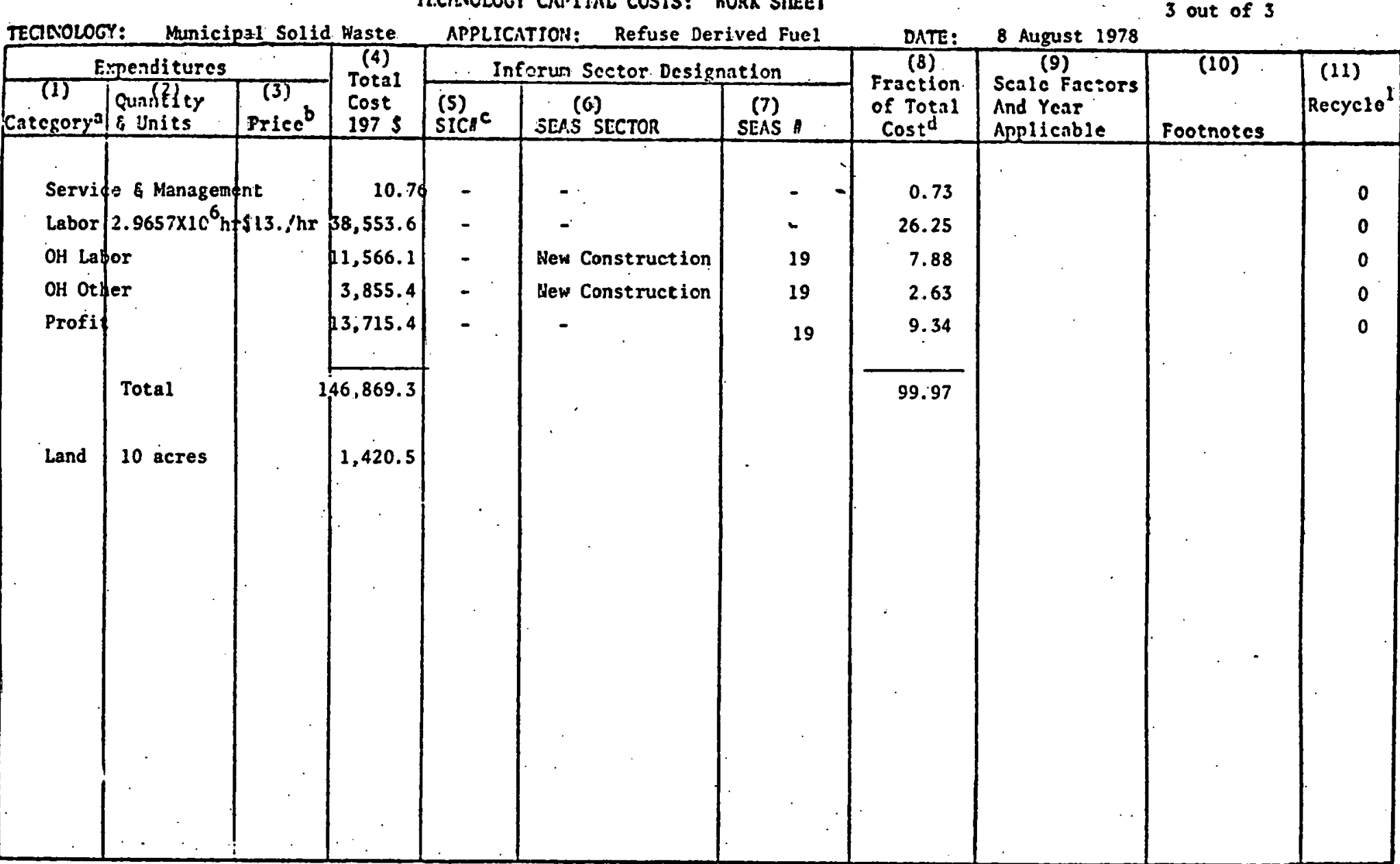

(a) For construction category, indicate the number of man-hours of labor required. (b) Prices should be for 1972. If other prices are used, indicate year. (c) 1967 SIC code. (d) Numbers may not add to totals due to roundling.

I I zyes, 2 no. Those ttems not recycled becone land residuals, quantities of recycled materials per $10^{12}$ annual Btu outpul are contained in the list of side equations. 
TECINCLCOY CAPITAL COSTS: HORK SIEET

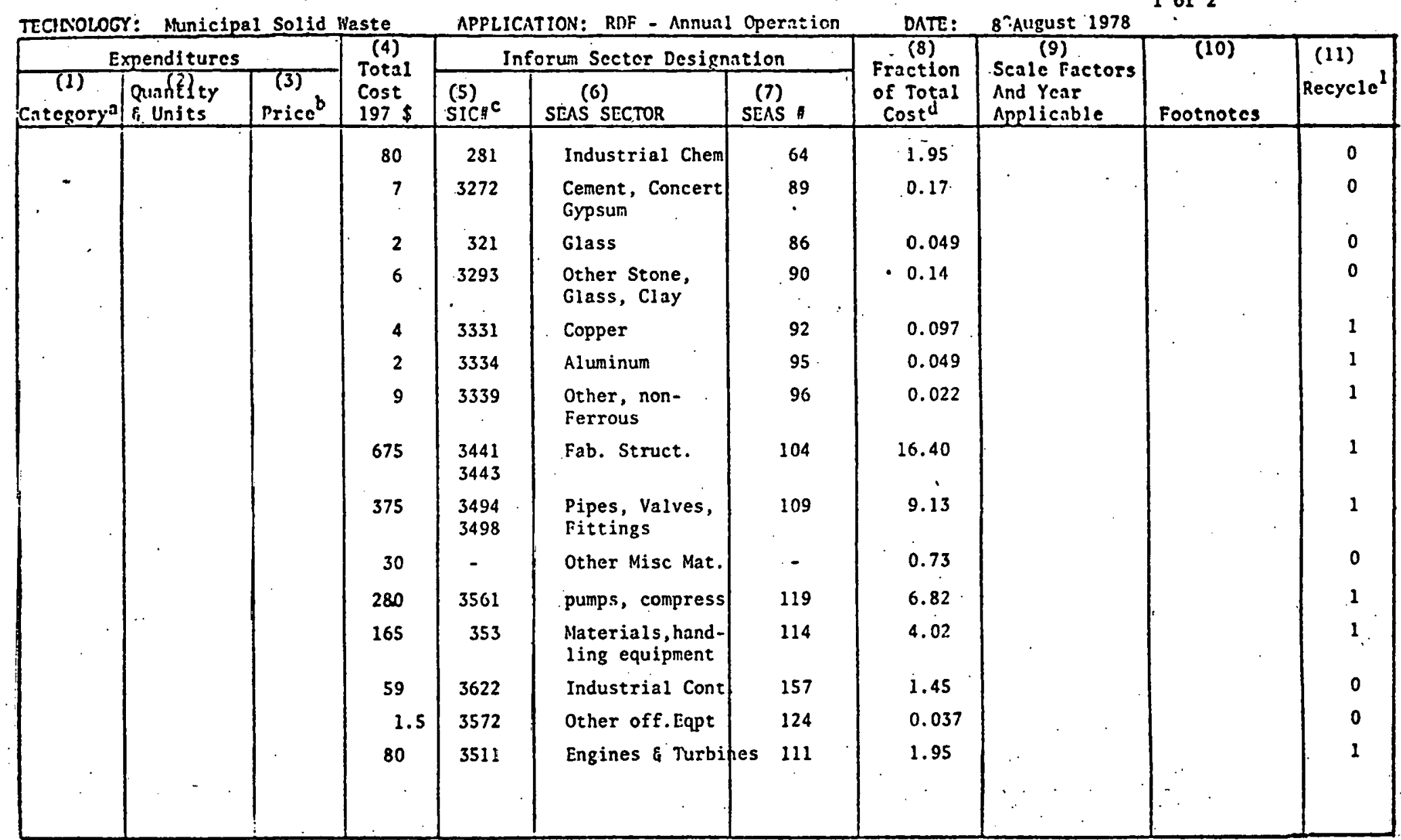

(a) For construction eategory; indica:e the number of man-hours of labor rcquired." (b) Prices should be for 1972. If other prices are used, Indicate year. (c) 1967 SIC code. (d) Nunbers may not add to totals due to rounding.

$1=$ yes, 2 no. Those itens not recycled becone land residuals, quantities of recyeled materials per $10^{12}$ annual Btu output are contained in the list of side equations. 
TECINOLCT EAPITAL COSTS: HORK SHEET

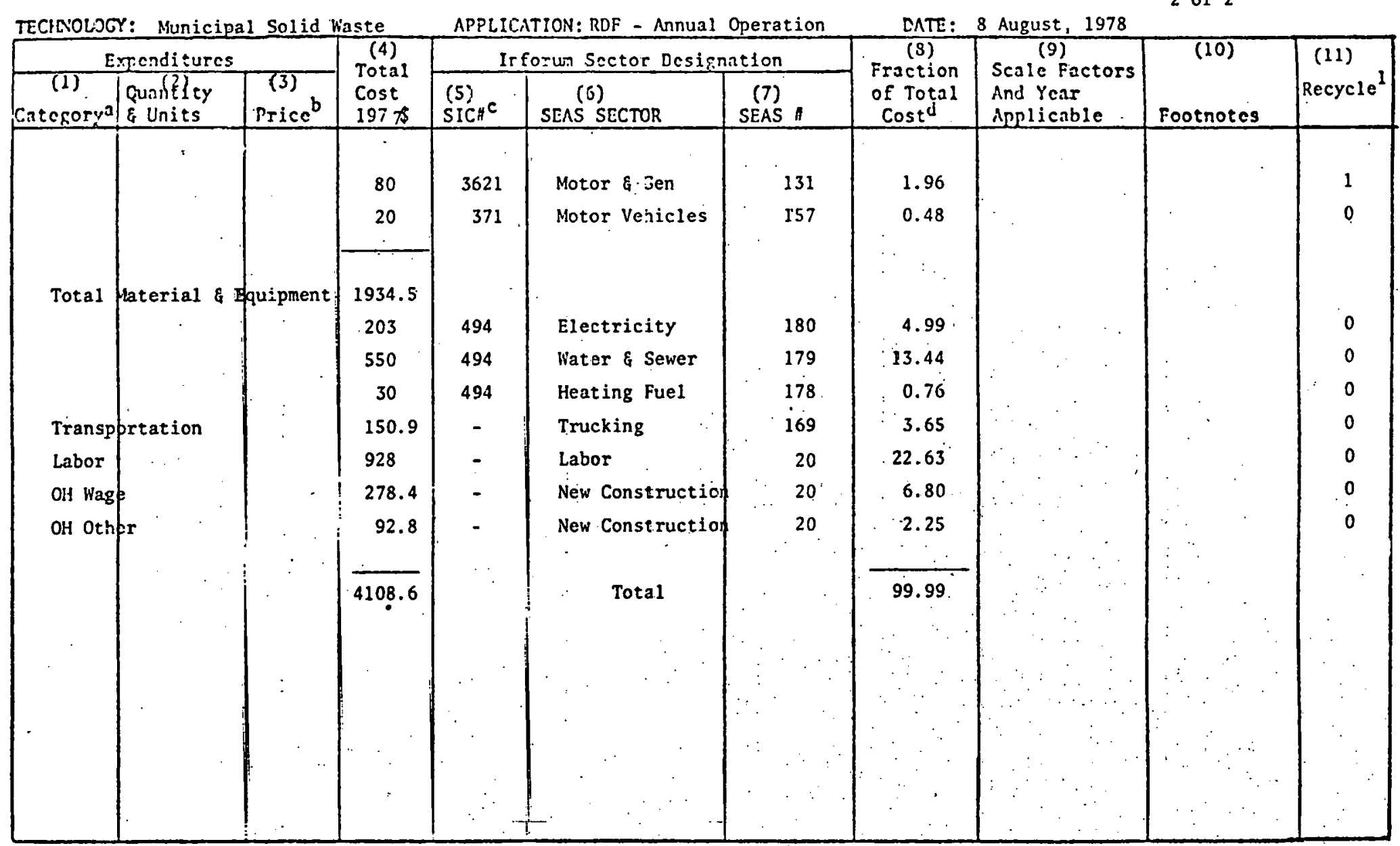

(a) For construction catcgory, indicate the number of man-hours of labor required. (b) Prices should be for 1972. If other prices are uset, indicate year. (c) 1967 SIC code. (d) Numbers may not add to totals due to rounding:

1 i jyes, 2 = no. Those itens not recycled becone land residuals, quantities of recycled naterials per $10^{12}$ annual Btu output are contained in the List of side equations. 


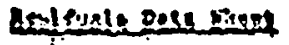

Atwingers

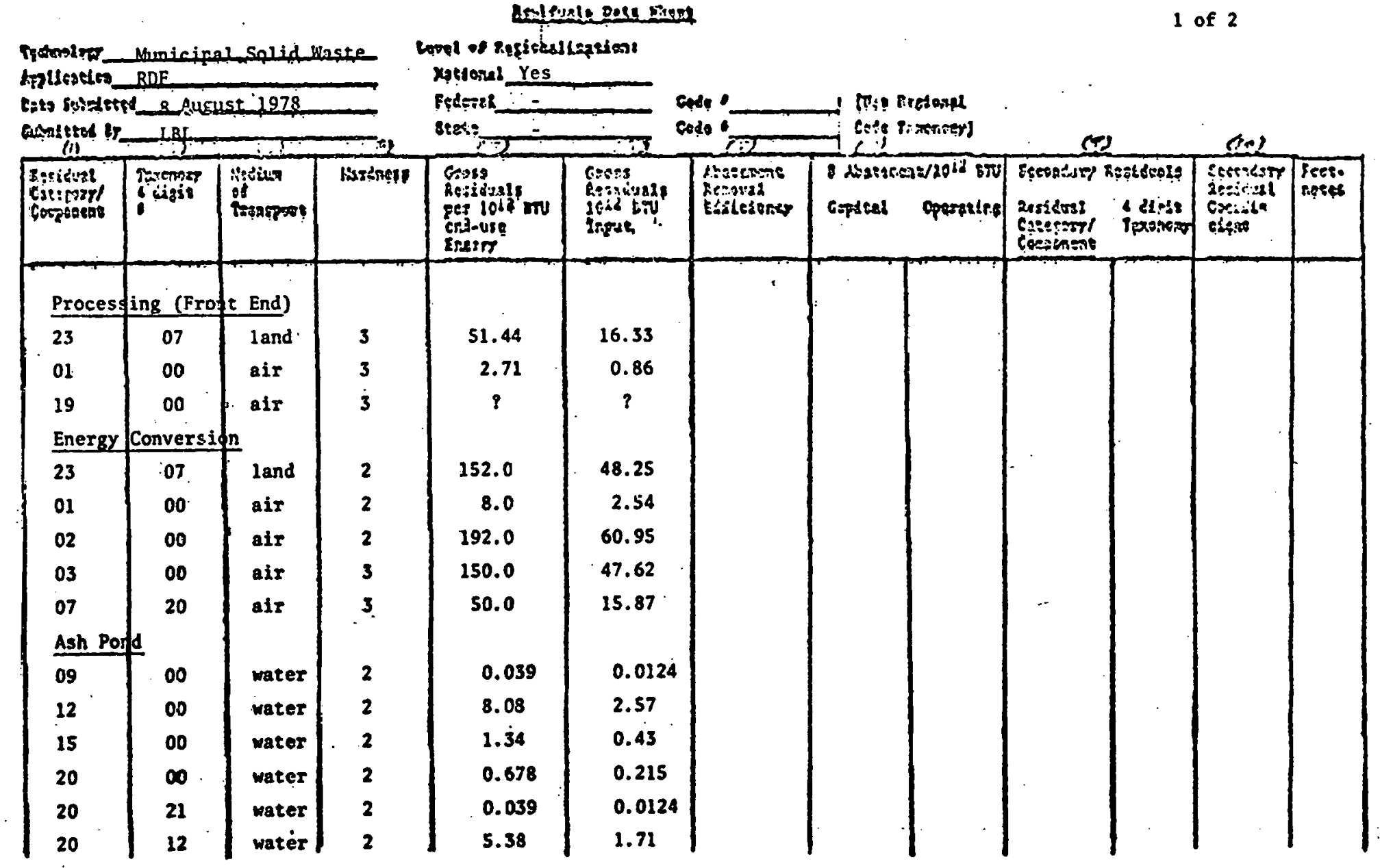




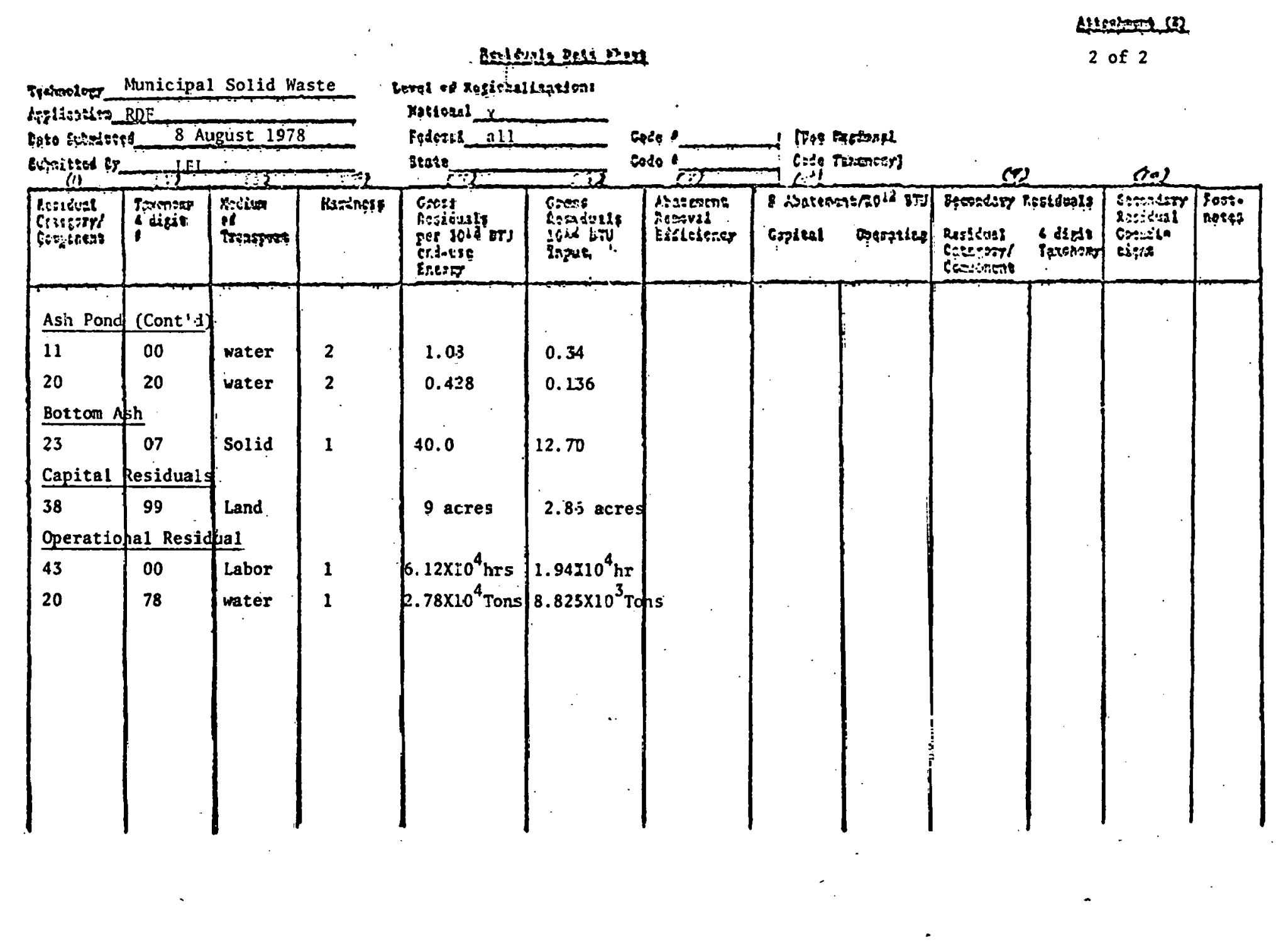




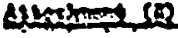

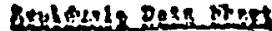

1 of 2

Tecrolog Nunicipal Solice linste Lipll:ables Direct Combustion

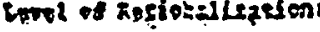
Yottemal Yes

eurritiod l\% Lawrence Berkcley Lab elo

Echicas

Cąa!

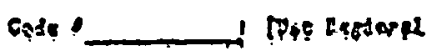

Case - cose

cose

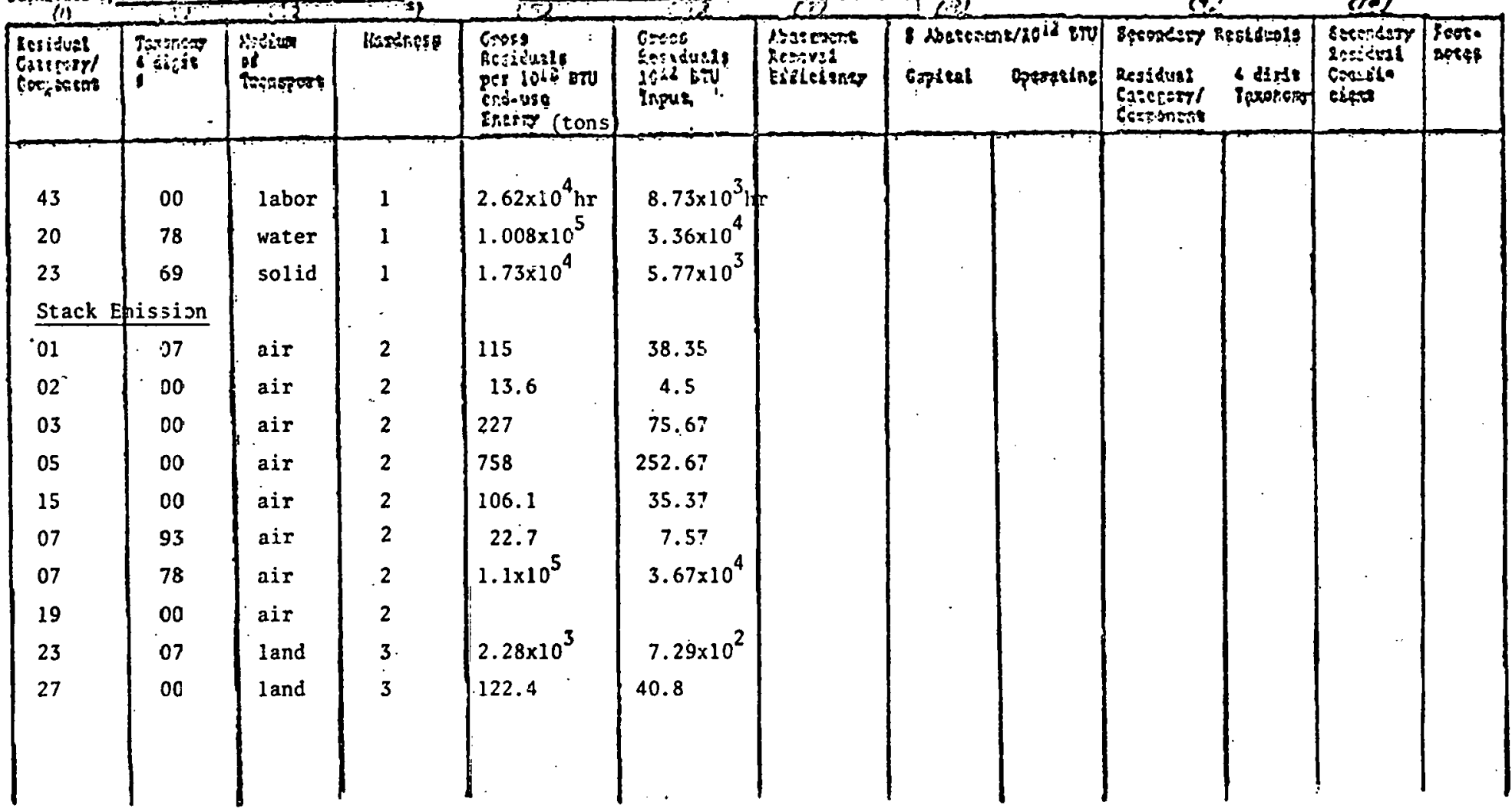


Lenfolespes now

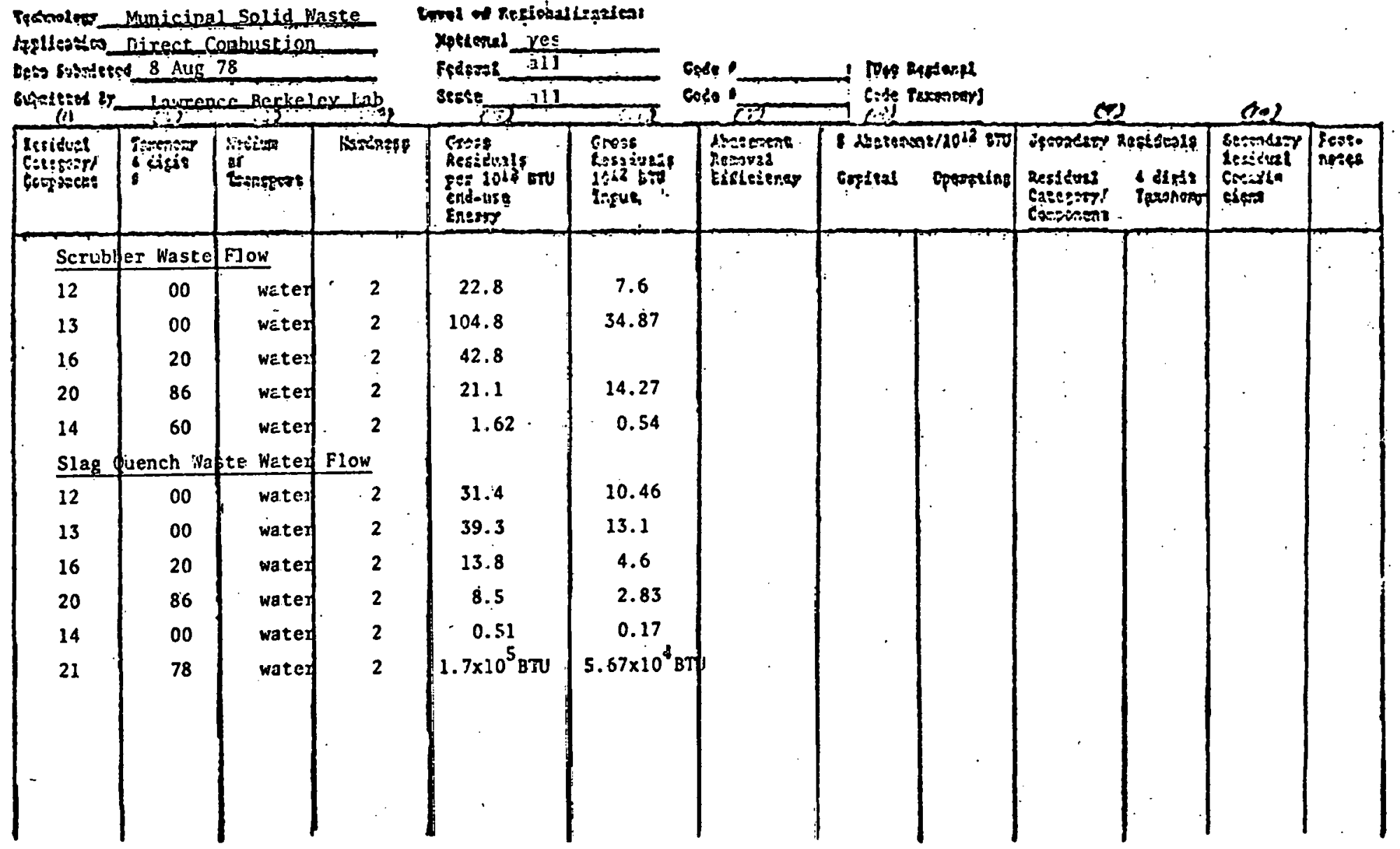


CAPITAL EXPE!IDITUPES ARII) MATERIALS REQUIREMEITS

SUI'UARY REPORTING FORH

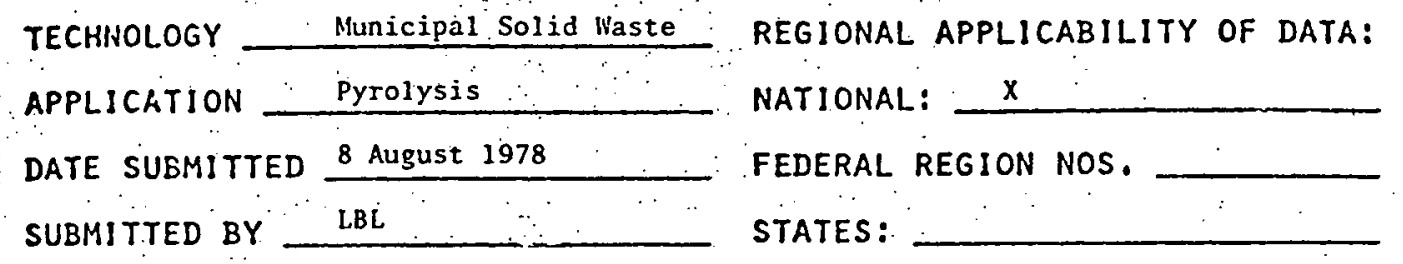

A. CAPital Costs

$\$ 1974$

DEFLATOR

$\$ 1972$

1. MATERials

$116,458,000$

1.18

$98,693,300$

2. TRANSPORTATION

$9,458,000$

1.18

3. CONSTRUCTION LABOR $50,708,000$

1.18

$7,994,100$

4. PROFIT \& OVERHEAD

$39,971,000$

1.18

$42,972,900$

A.1. TOTAL

$217,920,000$

1.18

$33,873,700$

B. AnNual System $10^{12}$ bTU Output

C. Annual System Fossil Fuel Equivalent $110^{12}$ bTU Dutput

D. Total Capital Cost/10 12 Annual btl $\left[\frac{A_{0}, 1}{B}\right]$.

E. ilui:ber of Years to Construct facility

$12,070,500$

F. Phasing of Construction Costs ( $\$$ each year):

\begin{tabular}{ll|lllllllll} 
YEAR & $\underline{1}$ & $\frac{2}{3}$ & $\underline{3}$ & $\underline{4}$ & $\underline{5}$ & $\underline{6}$ & $\underline{7}$ & $\underline{8}$ & $\underline{9}$ & $\underline{10}$
\end{tabular}

i $\quad 25$ is 25 25 - - - - - -

G. Expected Life of Facilitity (years)

H. Man Years to Construct facility

1. Man Years $/ 10^{12}$ bTU annual output $[\mathrm{H}]$

J. Estimated Land Use

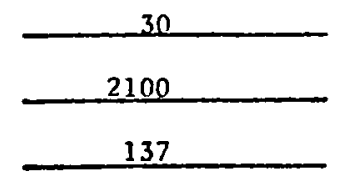

10 acres 
TECINOLOCY CAPITHL COSTS: HORK SHEET

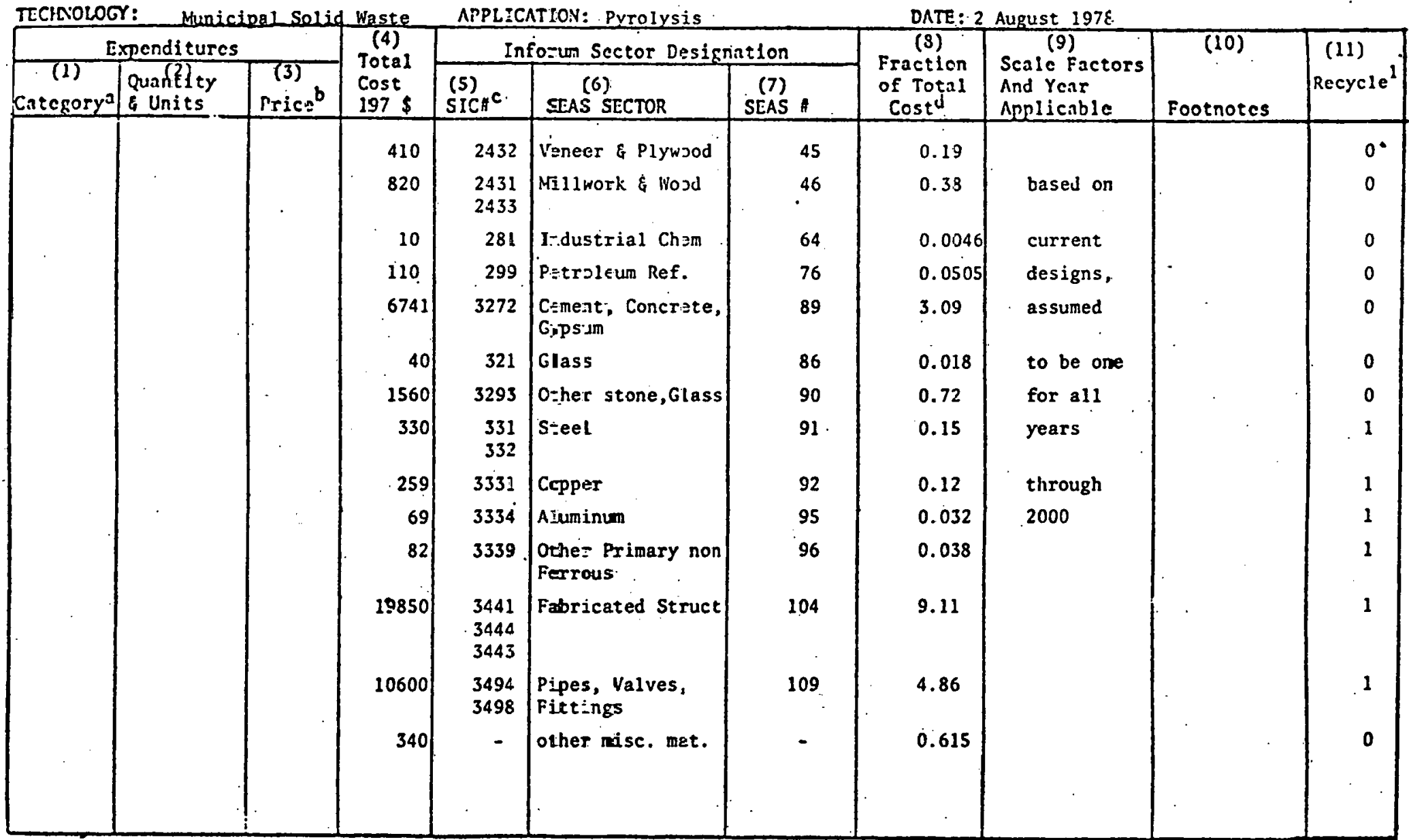

(a) For construction category, Indicate the number of nan-hours of labor required. (b) Prices should be for 1972. If other prices are uscd, Indicate year. (c) 1967 sic code. (d) Numbers may not add to totals due to rounding.

1 I yes, 2 no. Those itens not recycled beccue lasd residuals, quantities of recycled materials per $10^{12}$ annual Btu output are contained in the 1 is: of side equations. 
TECHNOLOG CAPITAL COSTS: HORK SHEET

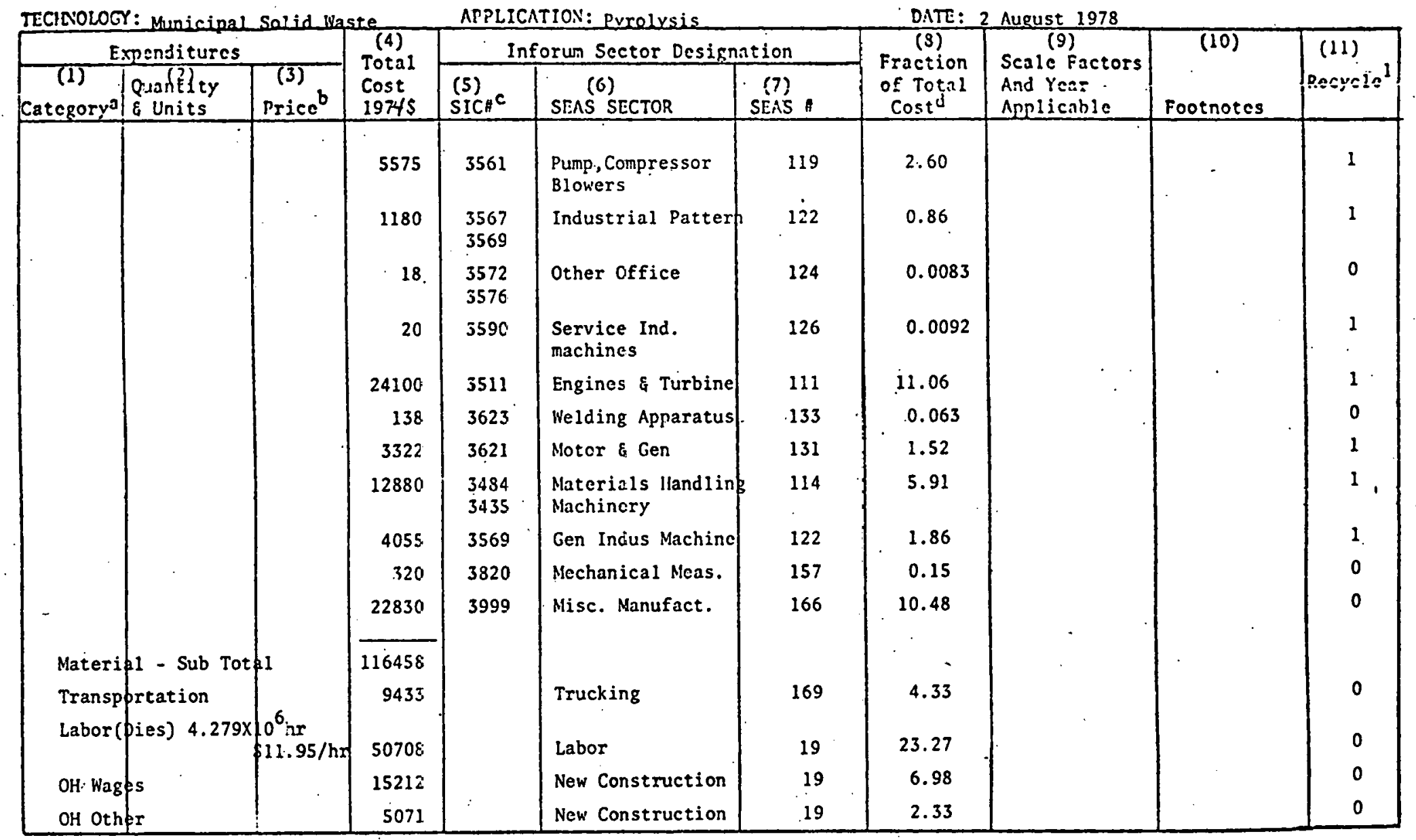

(a) For construction category, indicate the number of man-hours of labor required. (b) Prices should be for 1972. If other prices are used, indicate year. (c) 1967 SIC code. (d) Numbers may not add to totals due to rounding.

$11=$ yes, $z=$ no. Those items not recyeled become land residuals, quantities of recycled materials per $10^{12}$ annual Btu output are contained in the list of side equations. 
TECINCLOGY CAPITAL COSTS: HORK SIIEET

3 of 3

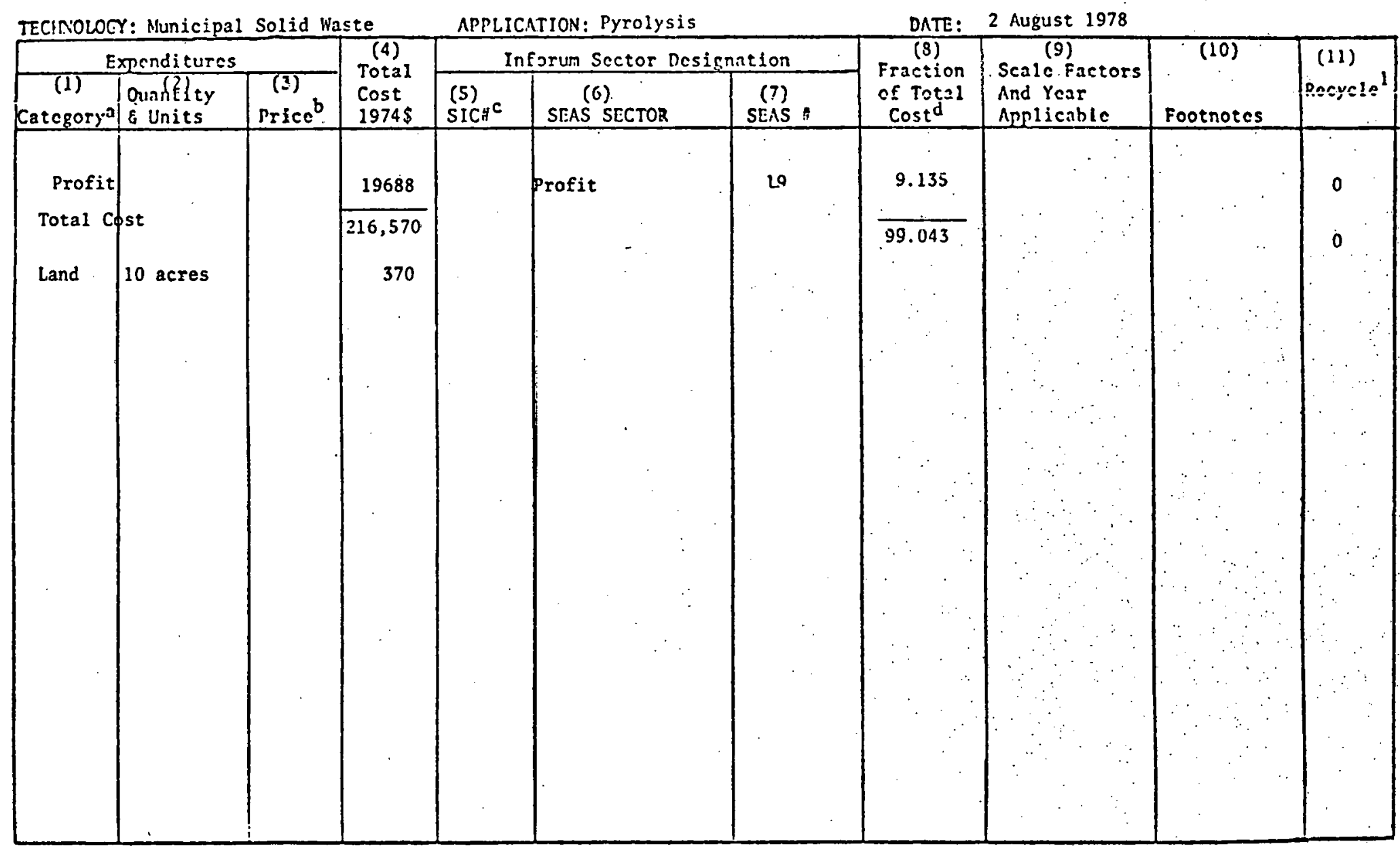

(a) For construction category, indicate the nimbar of man-hours of labor required. (b) Prices should be for 1972. If other prices are used, indicate year. (c) 1967 SIC code. (d) Numbers may not add to totals due to rounding.

11 y yes, 2 = no. Those itens not recycled become land residuals, quantities of recycled materials per $10^{12}$ annual Btu output are contained in the 1 ist of side equations. 
TECINOLOOY CAPITAL COSTS: HORK SILUET

1 of 2

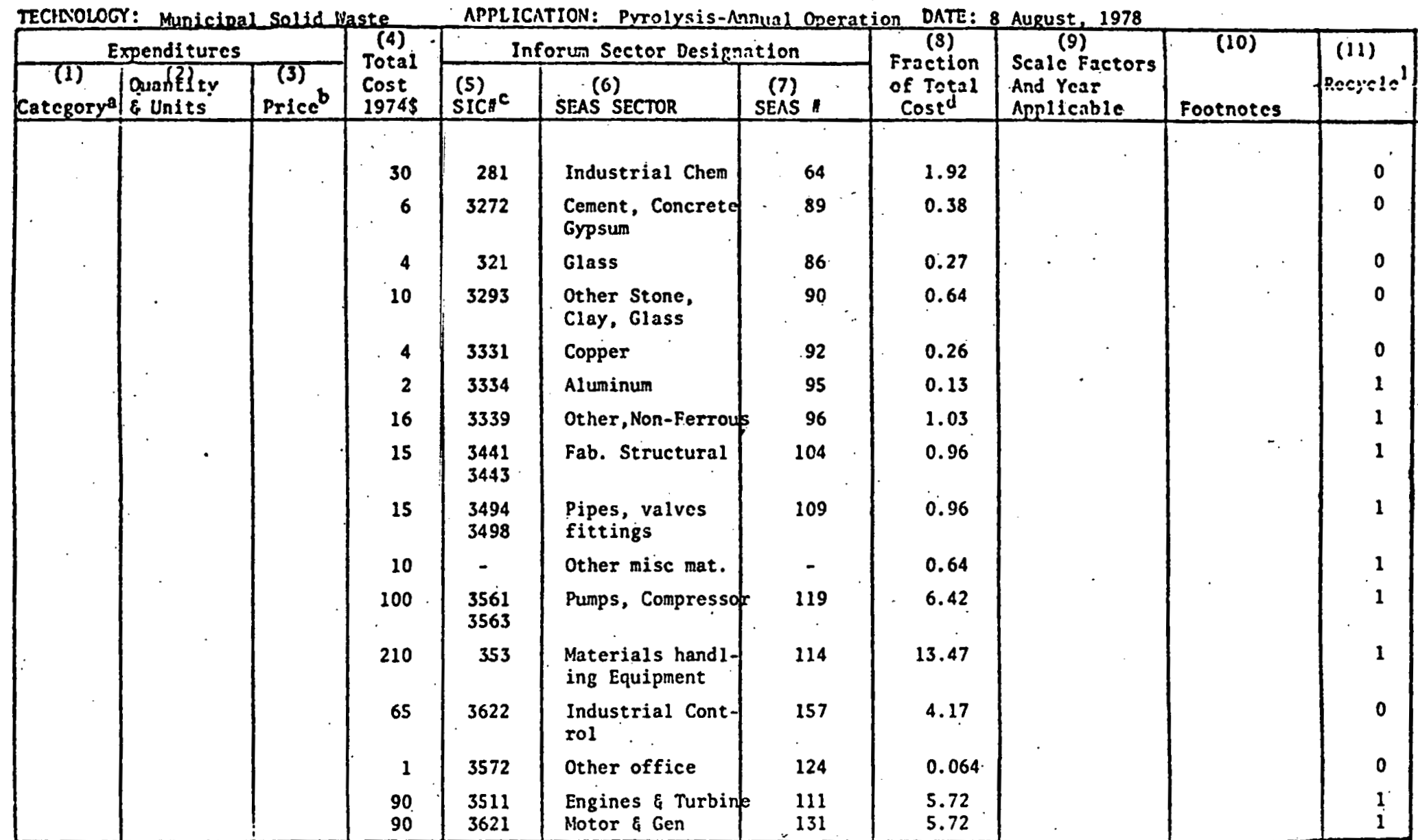

(a) For construction category, indicate the number of man-hours of labor required. (b) Prices should be for 1972. If other prices are used, indicate year. (c) 1967 SIC code. (d). Numbers may not add to totals due to rounding.

$12=$ yes, $2=$ no. Those items not recycled become.land residuals, quantities of recyeled materlals per $10^{12}$ arnual Btu output are contained in the list of side equations. 
TECHOLOGY CAPITAL COSTS: hORK SHEET

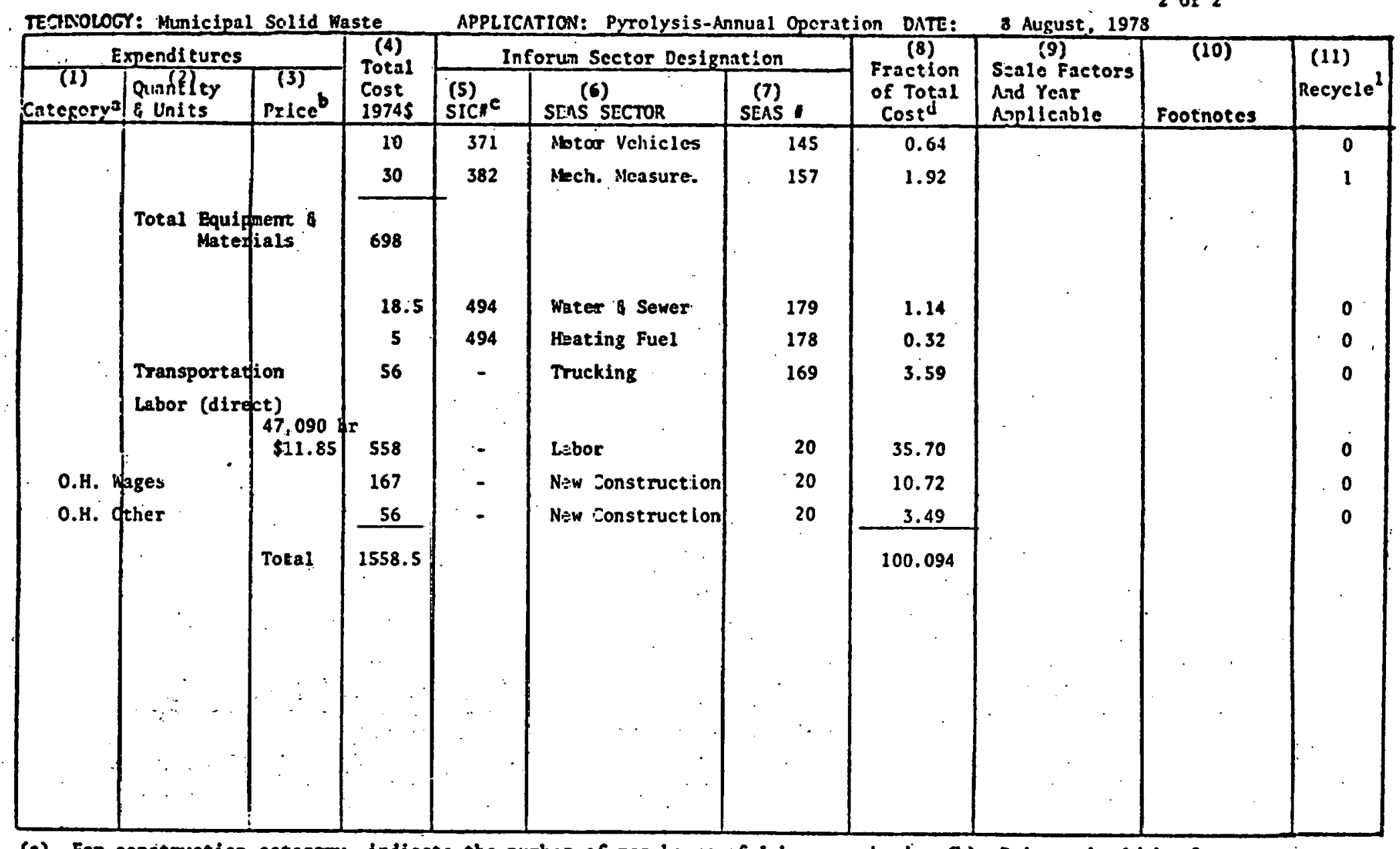

2 of 2

(a) For construction casegory, indicate the number of man-hours of labor required. (b) Prices'should be for ther prices a:e used, indivate year. ( 21967 SIC code. (d) Numbers may not add to totals due to rounding. 11 yes, 2 - no. Those items not recycled become land residuals, quantities of recycled naterials per
$10^{12}$ annual Btu output are contained in the list of side equations. 
Pramblen Municipal Solid Waste

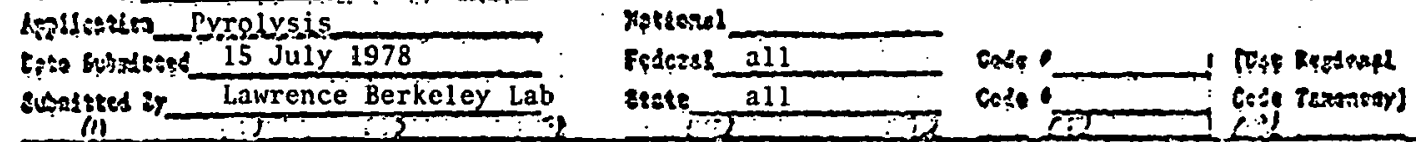

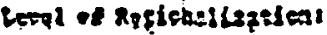

\begin{tabular}{|c|c|c|c|c|c|c|c|c|c|c|c|c|}
\hline & $T$ & 25 & $-i$ & 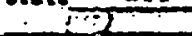 & $\because 2$ & $7:$ & 70. & & $c$ & & rel & \\
\hline 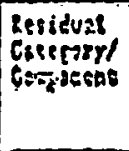 & tigitar & 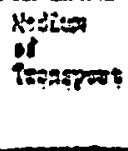 & Haxs? & 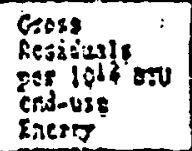 & 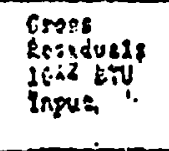 & 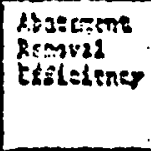 & $\begin{array}{l}\text { dexis: } \\
\text { cogital }\end{array}$ & $\begin{array}{l}18 / 20^{12} \operatorname{lTd} \\
0 p 90 p t \ln 6\end{array}$ & 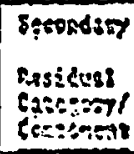 & $\begin{array}{l}\text { cestoults } \\
4 \text { deds } \\
\text { Ipronono }\end{array}$ & $\begin{array}{l}\text { expadst } \\
\text { sesidxal } \\
\text { cxisita } \\
\text { cipes }\end{array}$ & goos: \\
\hline 23 & 07 & land & 3 & 56.69 & 29.64 & & & & & & & \\
\hline 01 & 00 & air & 2 & 3.51 & 1.56 & & & & & & & \\
\hline 37 & 00 & water & 3 & $1.29 \times 10^{5} \mathrm{~T}$ & $5.75 \times 10^{4} \mathrm{~T}$ & - & & & & & & \\
\hline 38 & 99 & land & 1 & 61.3 acres & $27.3 \mathrm{acr}$ & - & & & & & & \\
\hline .19 & 00 & air & 5 & $\cdots$ & -- & .0 & & & & & & \\
\hline 43 & 00 & - & 1 & $1.486 \times 10^{5} \mathrm{hr}$ & $6.62 \times 10^{4} \mathrm{hr}$ & 0 & & & & & & \\
\hline 08 & 00 & air & 5 & -. & -- & 0 & & & & & & \\
\hline 21 & 78 & water & 2 & $3.17 \times 10^{11} \mathrm{Bt}$ & $1.41 \times 10^{11}$ & tru 0 & & & & & & : \\
\hline 15 & 20 & water & 2 & $1.23 \times 10^{3} \mathrm{~T}$ & $5.48 \times 10^{2}$ & 0 & & & & & & \\
\hline 20 & 47 & water & 2 & $1.26 \times 10^{-2} \mathrm{~T}$ & $5.62 \times 10^{-3}$ & 0 & & & & & " & ;: \\
\hline 20 & 80 & water & 2 & $3.99 \mathrm{~T}$ & $1.78 \mathrm{~T}$ & 0 & & & & & & \\
\hline 20 & 44 & water & 2 & $2.84 \mathrm{~T}$ & $1.27 \mathrm{~T}$ & 0 & & & & & & \\
\hline 20 & 88 & water & 2 & $1.29 \mathrm{~T}$ & $5.75 \mathrm{~T}$ & 0 & & & & & & \\
\hline 20 & 14 & water & 2 & $1.26 \times 10^{-2} \mathrm{~T}$ & $5.62 \times 10^{-3}$ & 0 & & $\ldots$ & & & & \\
\hline 22 & 00 & water & 2 & $3.93 \times 10^{3} \mathrm{~T}$ & $1.75 \times 10^{3} \mathrm{~T}$ & 0 & & & & & & \\
\hline 23 & 69 & land & 3 & $8.88 \times 10^{4} \mathrm{~T}$ & $3.96 \times 10^{4} \mathrm{~T}$ & 0 & & & & & & . \\
\hline 20 & 78 & water & 1 & $4.34 \times 10^{4} \mathrm{~T}$ & $1.935 \times 10^{4}$ & 0 & & & $\ldots$ & & & . \\
\hline
\end{tabular}


CAPITAL EXPE!IDITUPES AITI FIATERIGLS REQUIREMEMITS

SUPUTARY REPORTING FORH

TECHINOLOGY Cogeneration
APPLICATION Fluidized Bed
DATE SUBMITTED $\frac{8 \text { August 1978 }}{\text { LBL }}$
SUBMITTED BY

REGIONAL APPLICABILITY OF DATA: NATIONAL: FEDERAL REGION NOS all STATES:

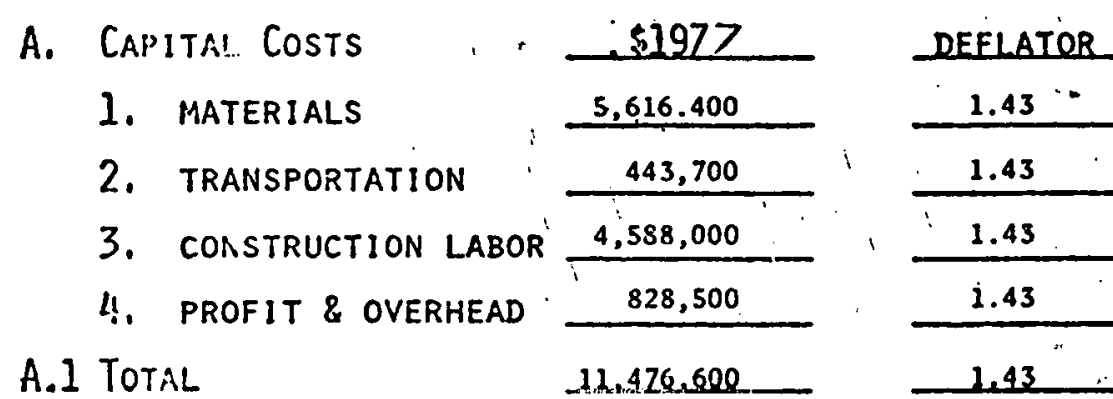

$\$ 2972$

B. AnNual SYstem $10^{12}$ bTU.OUTPut

C. Rinual System fossil Fuel Equivalent/1012 BTU Output

D. Total Capital Cost/10 12 Annual bTU $\left[\frac{A_{0} .}{B}\right]$

E. iturber of Years to Construct facility

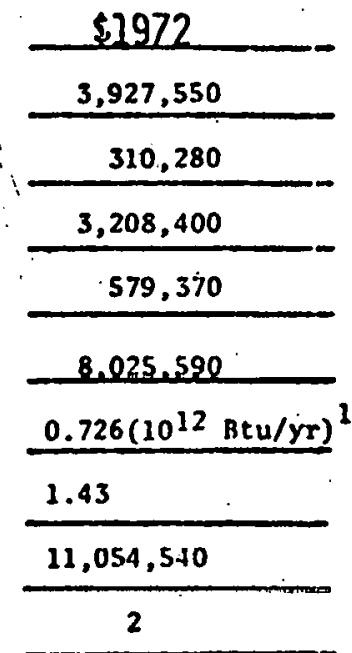

F. Phasing of Construction Costs (\$ each year):

$\begin{array}{lllllllllll}\text { YEAR } & 1 & 2 & \underline{3} & \underline{4} & \underline{5} & \underline{6} & \underline{7} & \underline{8} & \underline{9} & 10\end{array}$ $\%$ so se - - - - - - -

G. Exfected Life of Facility (years)

H. Man years to Construct Facility

I. Man Years/10 12 bTu annual output [H]

J. Estimated Land Use

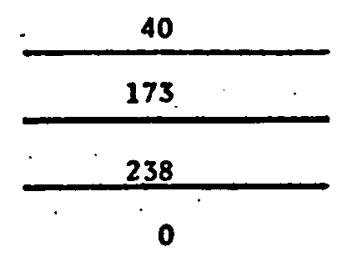

1 .See Appendix I or Application Section for details on product mix and fossil fuel equivaience 
TEC:F:OLOCY CAPITAL CistS: " hoRK SHLET

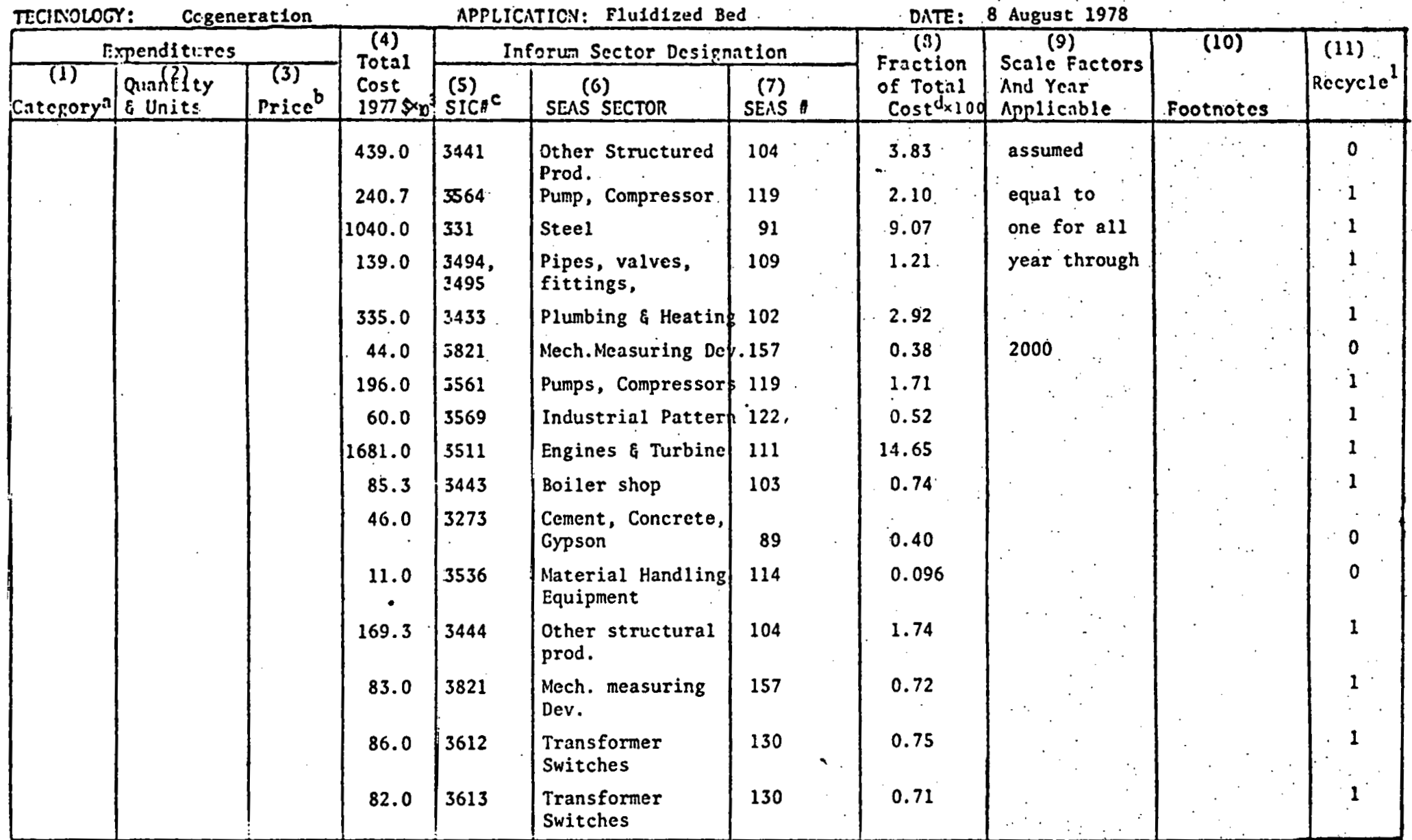

(a) For construction category, indicate the number of man-hours of labor required. (b) Prices should be for 1972. If other prices are used, indicate year. (c) 1967 SIC code. (d) Numbcrs may not add to totals due to rounding.

11 ycs, 2 = no. Those items not recycled become land residuals, quantities of recycled materials per $10^{12}$ annual Btu output are contained in the list of side equations.

(1) 1 =yes, 2 = no Those items not recycled become land residuals, quantities of recycled materials per $10^{12}$ annual BTC output are contained in the list of side equations. 
TECHNOLCCY CAPITAL CCSTS: - RORK SHEET

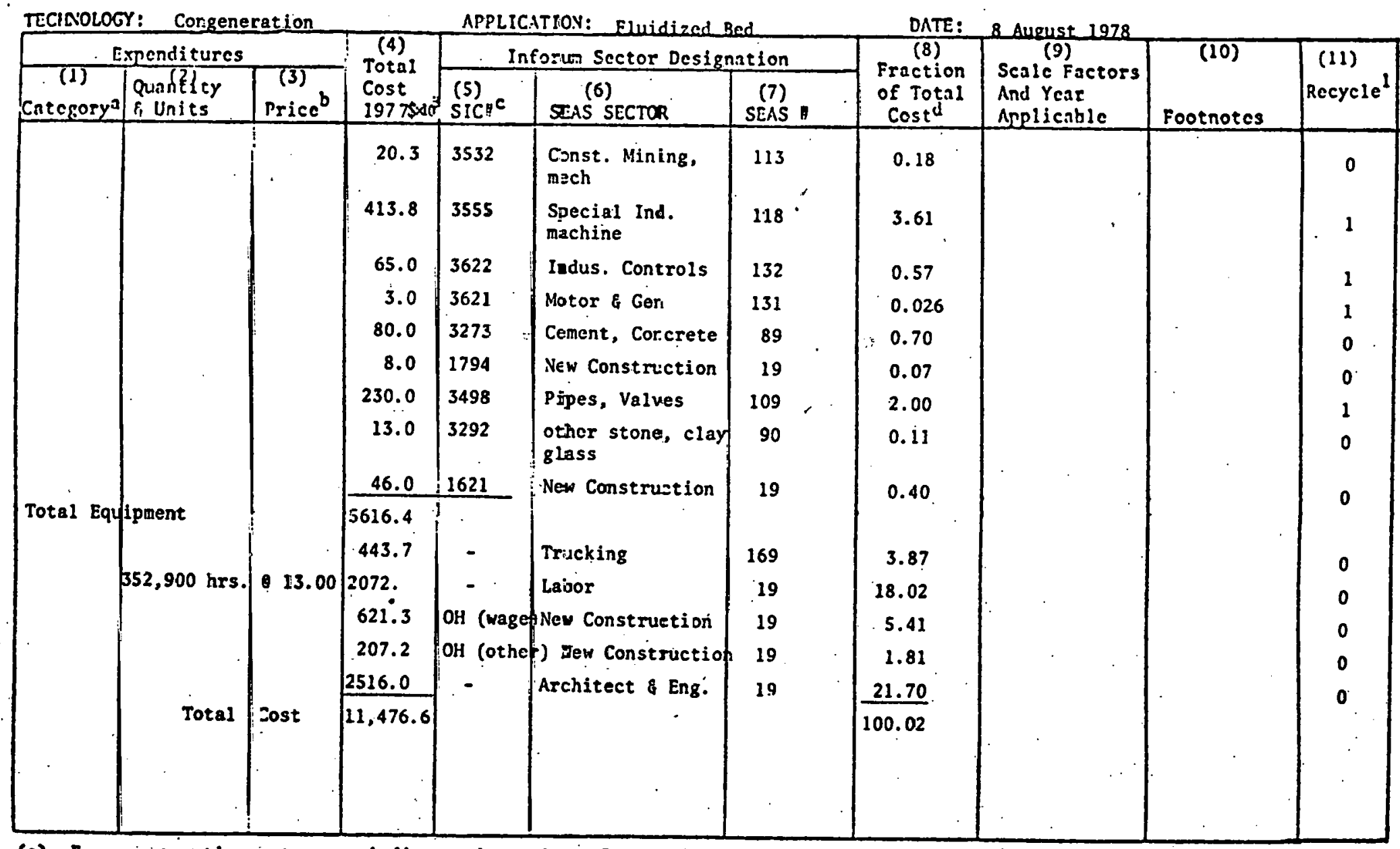

(a) For construction satcgory, indicate the number of man-hoirs of labor required. (b) Prices should be for 1972. If other prices are used, Indicate year. (c) 1967 SIC code. (d) Nunbers may not add to totals due to rounding. 1,1 yes, 2 no. Those itcms not recycled besome land residuals, quantities of recycled naterials per
$10^{12}$ annual Btu output are contained in the list of side cquations. 
TECINOLOOY CAPITAL COSTS: WORK SHEET / ANNUAL COSTS

\begin{tabular}{|c|c|c|c|c|c|c|c|c|c|c|}
\hline $\mathrm{N} O \mathrm{~L}$ & Cong & & & & S: & & & & & \\
\hline & xpenditures & & $\begin{array}{c}(4) \\
\text { Total }\end{array}$ & & orun Sector Design & ation & $\begin{array}{c}(8) \\
\text { Fraction }\end{array}$ & $\begin{array}{c}(9) \\
\text { Scale Factors }\end{array}$ & & \\
\hline $\begin{array}{c}\text { (1) } \\
\text { Eatcgory,a }\end{array}$ & $\begin{array}{l}\text { Guontelsy } \\
\text { \& Units }\end{array}$ & $\begin{array}{c}\text { (3) } \\
\text { Price } \\
\end{array}$ & $\begin{array}{l}\text { Cos: } \\
19765 \times 1 \\
\end{array}$ & $z_{0}^{(5)} \mathrm{cs}$ & $\begin{array}{c}\text { (6) } \\
\text { SEAS SECTOR }\end{array}$ & $\begin{array}{c}(7) \\
\text { SEAS A }\end{array}$ & $\begin{array}{l}\text { of Total } \\
\text { Costd } \\
\end{array}$ & $\begin{array}{l}\text { And Ycar } \\
\text { Anplicable }\end{array}$ & & Recjole \\
\hline - & 1 & . & $\begin{array}{r}0 \\
5 \\
1 \\
1 \\
30 \\
1 \\
20 \\
50 \\
10 \\
\\
2 \\
20 \\
5 \\
4 \\
20 \\
13 \\
550 \\
165 \\
55 \\
952\end{array}$ & $\begin{array}{r}2431 \\
281 \\
321 \\
3293 \\
331 \\
3339 \\
3<41 \\
3443 \\
3499 \\
3494 \\
3569 \\
3434, \\
3435 \\
3561 \\
3622 \\
3670 \\
9433 \\
- \\
- \\
-\end{array}$ & \begin{tabular}{|l|} 
Mllwork - wood \\
Indus. Chem. \\
Gass \\
Other stone \& \\
Clay \\
Iron and steel \\
Non-Ferrous metal \\
Fabricated \\
Structural \\
Fabricated Metai \\
Pipes, valves, \\
Fittings \\
Cen. Indus. Equip. \\
Mbterial handling \\
Equiprant \\
Pump, comp., blower \\
Control Equip. \\
Electrical Equip. \\
Trucking \\
Labor \\
Overhead (wages) \\
Overhead (other)
\end{tabular} & $\begin{array}{r}46 \\
64 \\
86 \\
90 \\
91 \\
96 \\
104 \\
110 \\
109 \\
122 \\
114 \\
119 \\
132 \\
139 \\
169 \\
20 \\
20 \\
20\end{array}$ & $\begin{array}{c}0 \\
0.53 \\
0.11 \\
0.11 \\
3.15 \\
0.11 \\
2.10 \\
5.25 \\
1.05 \\
0.21 \\
\\
2.10 \\
0.53 \\
0.42 \\
2.10 \\
1.37 \\
57.76 \\
17.33 \\
5.78 \\
100.01\end{array}$ & $\begin{array}{l}\text { Assumed } \\
\text { Equal to } 1 \\
\text { For all Costs }\end{array}$ & & $\begin{array}{l}0 \\
0 \\
0 \\
0 \\
1 \\
1 \\
0 \\
1 \\
1 \\
1 \\
1 \\
1 \\
0 \\
0 \\
0 \\
0 \\
0 \\
0 \\
0\end{array}$ \\
\hline
\end{tabular}

(a) For construction category, Indicate the number of man-hours of labor required. (b) Prices should be for 1972. If other prices are used, indicate year. (c) 1967 . SIC code. (d) Nubers may not add to totals due to rounding. (e) $1=$ yes, $z=$ no. Items not recycled may be considered to be operational residuals. 


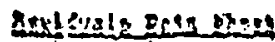

4452

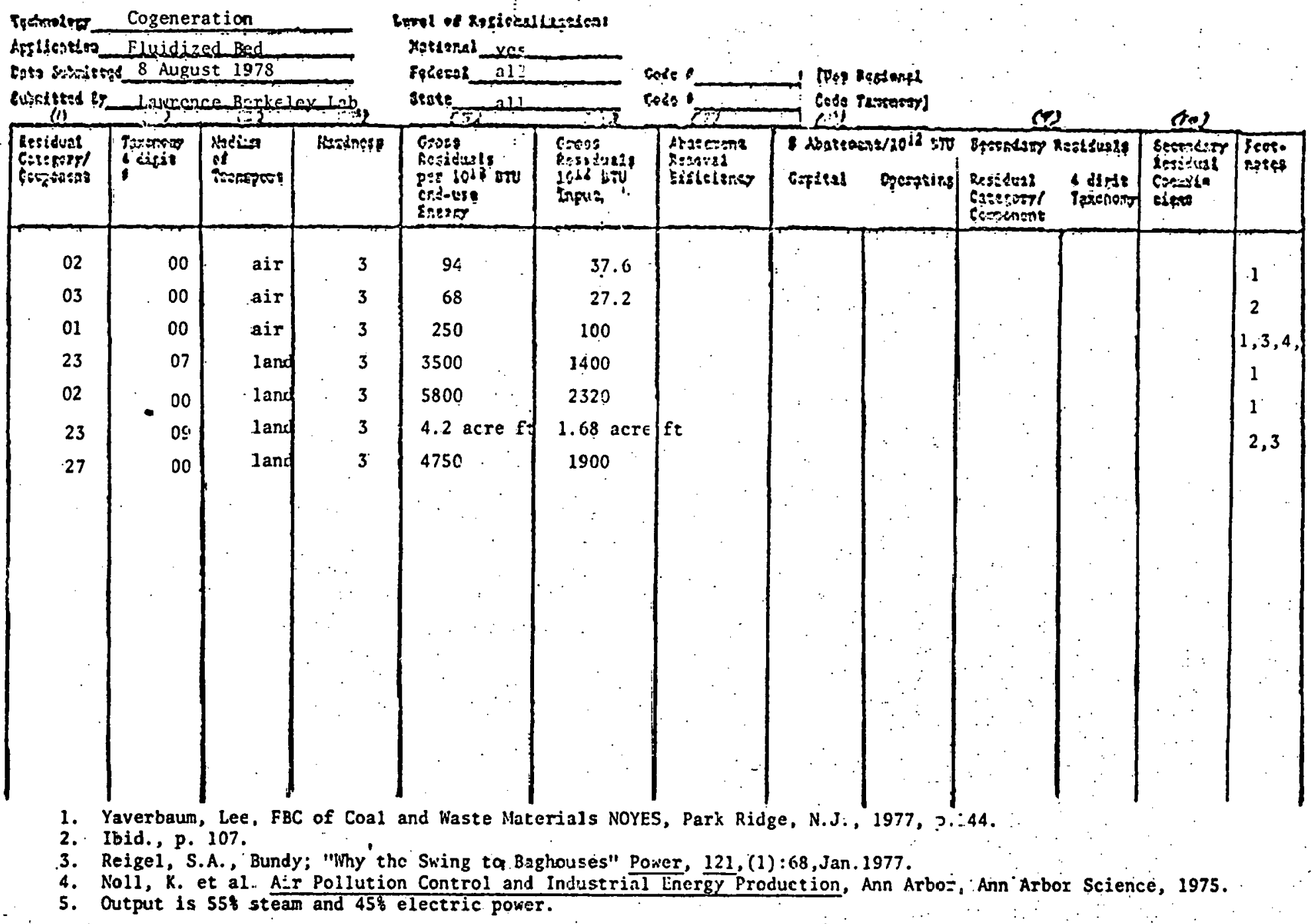


CAPITAL EXPE!IDITUPES AYD MATERIALS REQUIREMEMITS

SUIUTARY REPORTING FORUI

TECHNOLOGY $\frac{\text { Cogeneration }}{\text { APPLICRTION DLese1 }}$
DATE SUBMITTED $\frac{8 \text { AUgUST 1978 }}{\text { LBL }}$
SUBMITTED BY

REGIONAL APPLICABILITY OF DATA:

NATIONAL:

$\mathrm{X}$

FEDERAL REGION NOS, al1

STATES:

ali

A. Capital Costs

$\$ 1977$

DEFLATOR

$\$ 1972$

1. MATERIALS

$5,359,100$

1.28

$4,186,800$

2. TRANSPORTATION

418,000

1.28

326,560

3. CONSTRUCTION LABOR

$1,656,500$

1.28

4. PROFIT \& OVERHEAD

600,000

1.28

$, 294,140$

$\frac{600,000}{8,033,600}$

$\frac{1.28}{1.28}$

A.1 TOTAL

B. ANNUAL SYSTEM $10^{12}$ bTU OUTPUT

C. Annual System fossil fuel Equivalent/10 12 Btll Output

D. Total Capital Cost/10.12 annual BtU $\left[\frac{A .1}{B}\right]$

E. lluirber of Years to Construct Facility 468,750

F. Phasing of Construction Costs (\$ each year):

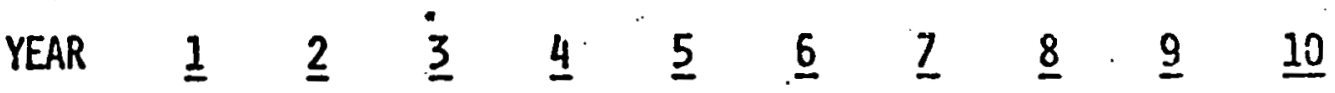
\% 100 - ----

6. Expected Life of Facilitity (years)

H. Man years to Construct facility

1. Man Years $/ 10^{12}$ btu annual output $\left[\frac{\mathrm{H}}{\mathrm{B}}\right]$

$\frac{20}{60.5}$

J. Estimated Land Use.

${ }^{1} \varepsilon_{00}$ Appendix I for dẹtails on product mix and fossil fuel equivating calculations 
TECM:OLCOY CAPITAL COSTS: HORK SHEET

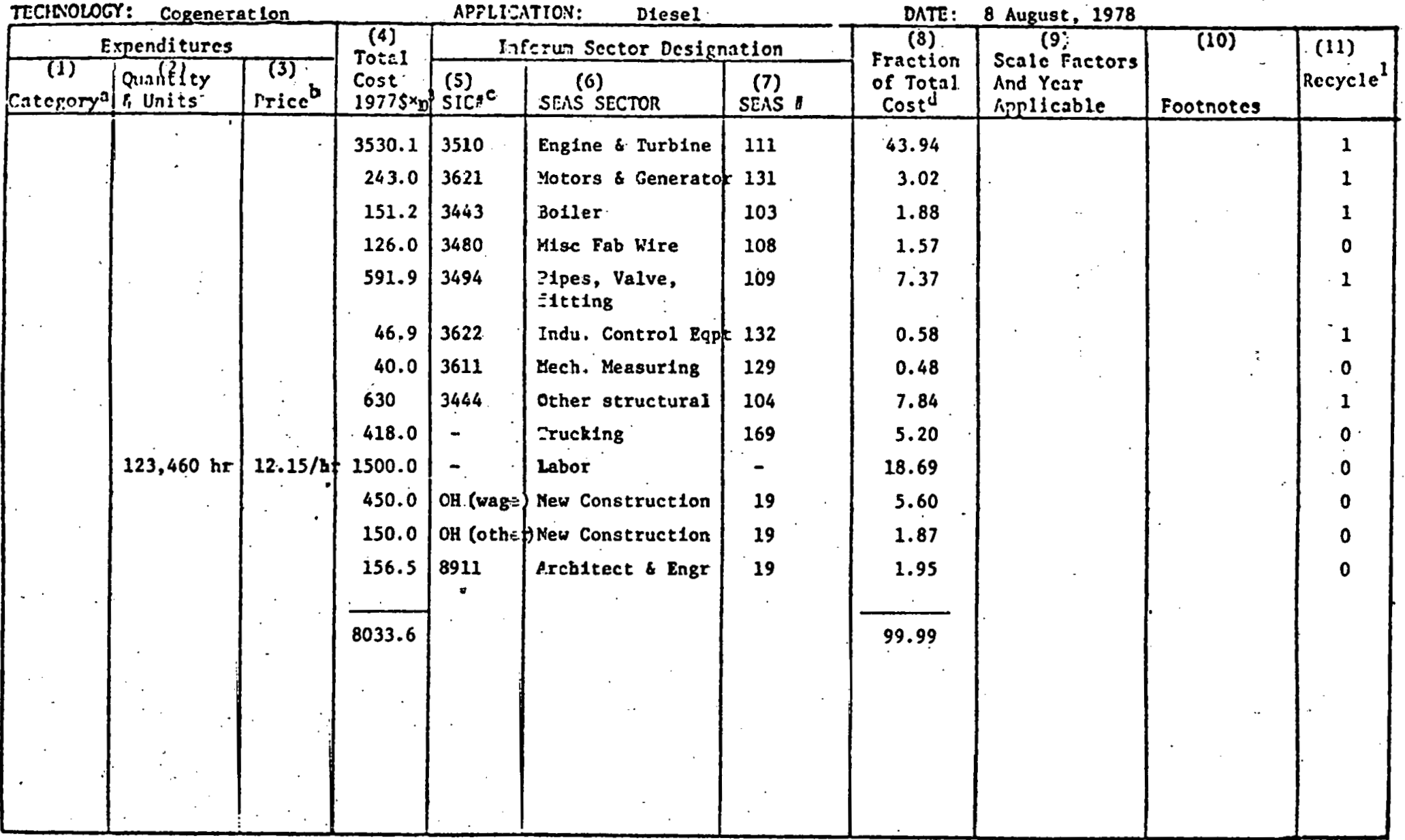

(a) For construction category, indicate the nimber, of man-hours of labor required. (t) Prices should be for 1972. If other prices are used, Indicate year. (c) 1967 SIC code. (d) Numbers may not add to totals due to rounding.

1 1 5 yes, $2=$ no. Those items not recycled become land residuals, quantitics of recycled materials per $10^{12}$ annual Btu outpu: are contained in the Iist of side equations. 


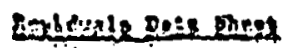

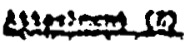

7. Amping Cogeneration

hopllestom Diesel Engine

Dize Ploderfs 8 Aug. 1978

imal of argirtadicetital

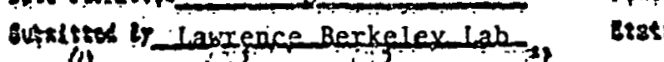

rattonel

Fqueser

3.11

- Codẹ.

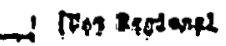

ctase

2

Codse

Cofit Texonisary

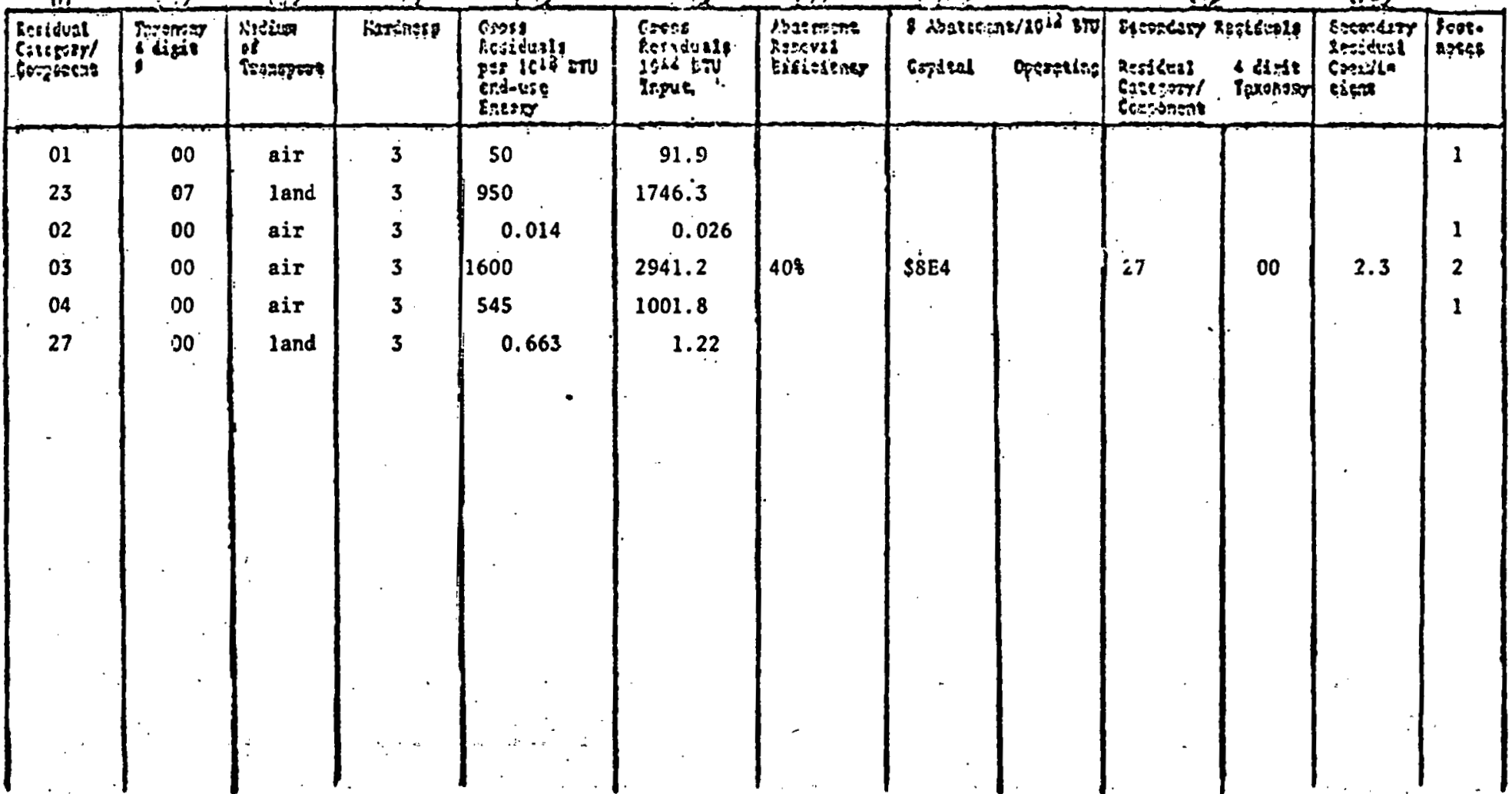

1. Fron EPA, Air Pollution Emission Factors, AP-42.

2. Thomson, S.J. and Crow, "Energy Costs of Nox Control" Hydrocarbon Processing, May 1976 
CAPITAL EXPE!IDITURES AUI MATERIALS REQUIREMENTS SUIMTARY REPORTING FORH

TECHIOLOGY Cogeneration
APPLICATION Enhanced Oil Recovery
DATE SUBMITTED 8 AuguSt 1978
SUBMITTED BY LBL
REGIONAL APPLICABILITY OF DATA: NATIONAL: $x$ FEDERAL REGION NOS. all STATES: a11
A. Capital Costs

1. MATERIALS

2. TRANSPORTATION

3. CONSTRUCTION LABOR

4. PROFIT \& OVERHEAD

A.1 TOTAL

B. nNNual System $10^{12}$ bTU OUtput

C. Ainual System Fossil fuel Equivalent/1012 bTU Output

D. Total Capital Cost/1012 annual Btu $\left[\frac{A \cdot d}{B}\right]$

E. iluli:Ber of Years to Construct facillity

F. Phasing of Construction Costs ( $\$$ each year),

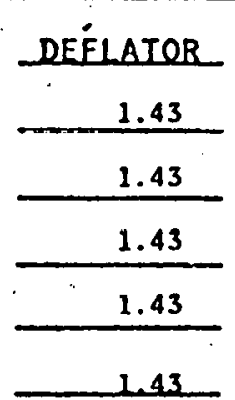

$\$ 1972$

$131,472,000$

$\frac{10,209,800}{76,161,000}$

245.534 .800

$15\left(10^{12}\right.$ BTU/yr)

$25\left(10^{12} \mathrm{BTU} / \mathrm{yr}\right)$

$16,369,000$ 4

$9 \quad 10$

$\% \quad 25$. $25 \quad \underline{25}$. 25

G. EXpected Life of Facilitty (years)

H. Man years to Construct facilitity

1. Man Years $/ 10^{12}$ btu annual output [H]

J. Estimated Land Use
20 years

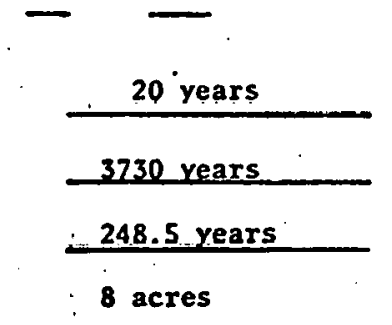


TECINCLON CAPITAL COSTS: MCNX SIIEET

\begin{tabular}{|c|c|c|c|c|c|c|c|c|c|c|}
\hline Tranoloor: & \multicolumn{2}{|c|}{ Cogeneration } & \multicolumn{4}{|c|}{ APPLICATIOV: Enhanced Oil Recovery } & \multicolumn{4}{|c|}{ DATE: 8 Auqust 1978} \\
\hline & penditure & & \multirow{2}{*}{$\begin{array}{l}(4) \\
\text { Total } \\
\text { Cost } \\
19775 \times 1 \\
\end{array}$} & \multicolumn{3}{|c|}{ Infortun Sector Designation } & \multirow{2}{*}{$\begin{array}{l}\text { (3) } \\
\text { Fraction } \\
\text { of Total } \\
\text { Costd }\end{array}$} & \multirow{2}{*}{$\begin{array}{l}\text { (9) } \\
\text { Scale Factors } \\
\text { And Year } \\
\text { Applicible }\end{array}$} & \multirow{2}{*}{$\begin{array}{c}\text { (10) } \\
\text { Footnotcs } \\
\end{array}$} & \multirow{2}{*}{$\begin{array}{c}\text { (11) } \\
\text { Recycle }\end{array}$} \\
\hline $\begin{array}{c}\text { (1) } \\
\text { Cnteroryan }\end{array}$ & $\begin{array}{l}\text { Qunnilety } \\
\text { g. Units }\end{array}$ & $\begin{array}{c}(3) \\
\text { Price }^{b}\end{array}$ & & ${ }^{(5)}$ & $\begin{array}{c}(6) \\
\text { SEAS SECTOR }\end{array}$ & $\begin{array}{c}\text { (7) } \\
\text { SENS : } \\
\end{array}$ & & & & \\
\hline : & . & . & $\begin{array}{c}1170 \\
2360 \\
5495 \\
3990 \\
4320 \\
75 \\
1780 \\
\\
41,200 \\
410 \\
180 \\
500 \\
25,700 \\
15,800 \\
17,145 \\
1040 \\
12,430 \\
30,000\end{array}$ & \begin{tabular}{|c}
2432 \\
2431, \\
2433 \\
281 \\
299 \\
3272 \\
\\
321 \\
3293 \\
\\
331,332 \\
3331 \\
3334 \\
3335 \\
3443 \\
3444 \\
3494 \\
3498 \\
3441 \\
3450 \\
- \\
3511
\end{tabular} & $\begin{array}{l}\text { Veneer \& Plywood } \\
\text { Millwork \& Wood } \\
\text { Industrial Chem } \\
\text { Petroleum Refin. } \\
\text { Cement; Concrete } \\
\text { Gypsum. } \\
\text { Glass } \\
\text { Other Stone, . } \\
\text { Clay, Glass } \\
\text { Steel } \\
\text { Copper. } \\
\text { Aluninum } \\
\text { other non-ferrous } \\
\text { Fabricated } \\
\text { Structural } \\
\text { Pipe, Valve, } \\
\text { Fittings } \\
\text { Dther Structural } \\
\text { Machine Products } \\
\text { Other misc. Mat. } \\
\text { Engines \& Tubine }\end{array}$ & $\begin{array}{c}45 \\
46 \\
64 \\
76 \\
89 \\
86 \\
90 \\
91 \\
92 \\
95 \\
96 \\
104 \\
\vdots \\
109 \\
104 \\
105 \\
110 \\
111\end{array}$ & $\begin{array}{l}0.33 \\
0.67 \\
1.57 \\
1.14 \\
1.23 \\
0.021 \\
0.51 \\
11.73 \\
0.12 \\
0.051 \\
0.14 \\
7.32 \\
4.50 \\
4.88 \\
0.30 \\
3.54 \\
8.54\end{array}$ & $\begin{array}{l}\text { assumed } \\
\text { equal to } \\
\text { one for all } \\
\text { years } \\
\text { through } \\
2000\end{array}$ & . & $\begin{array}{l}0 \\
0 \\
0 \\
0 \\
0 \\
0 \\
0 \\
1 \\
1 \\
1 \\
1 \\
1 \\
1 \\
1 \\
1 \\
0 \\
1\end{array}$ \\
\hline
\end{tabular}

(a) For constriction category, indicate the number of man-hours of labor required. (b) Prices should be for 1972. If other prices are used, indicate year. (c) 196 ? SIC code. (d) Numbers may not add to totals due to rourding.

1, yes, 2 ano. Those items not recycled become land residuals, quantities of recycled materials per $10^{12}$ annual BtL output are contained in the list of side equations. 
TECINCLCOY CAPITAL COSTS: WORK SIIEET

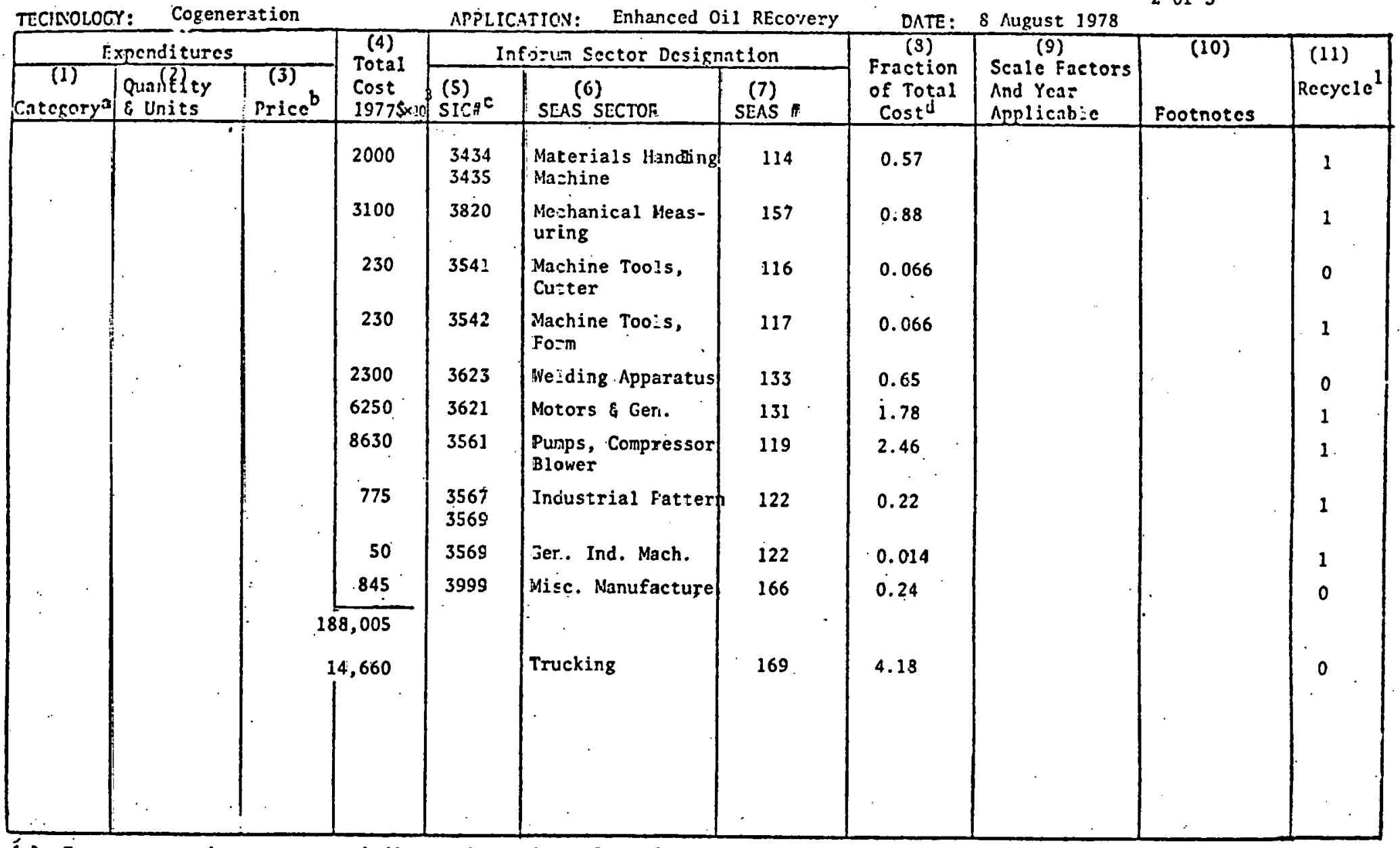

(a) For construction eategory, indicate the nubbez of man-hours of laboz required. (b) Prices should be for 1972. If other prices are used, Indicate year. (c) 1967 SIC code. (d) Numbers may not add to totals due to rounding. 1 Ij yes, 2 = no. Those items not recycled become land residuals, quantitics of recycled materlals per
10 annual Btu output are contained in the list of side equations. 


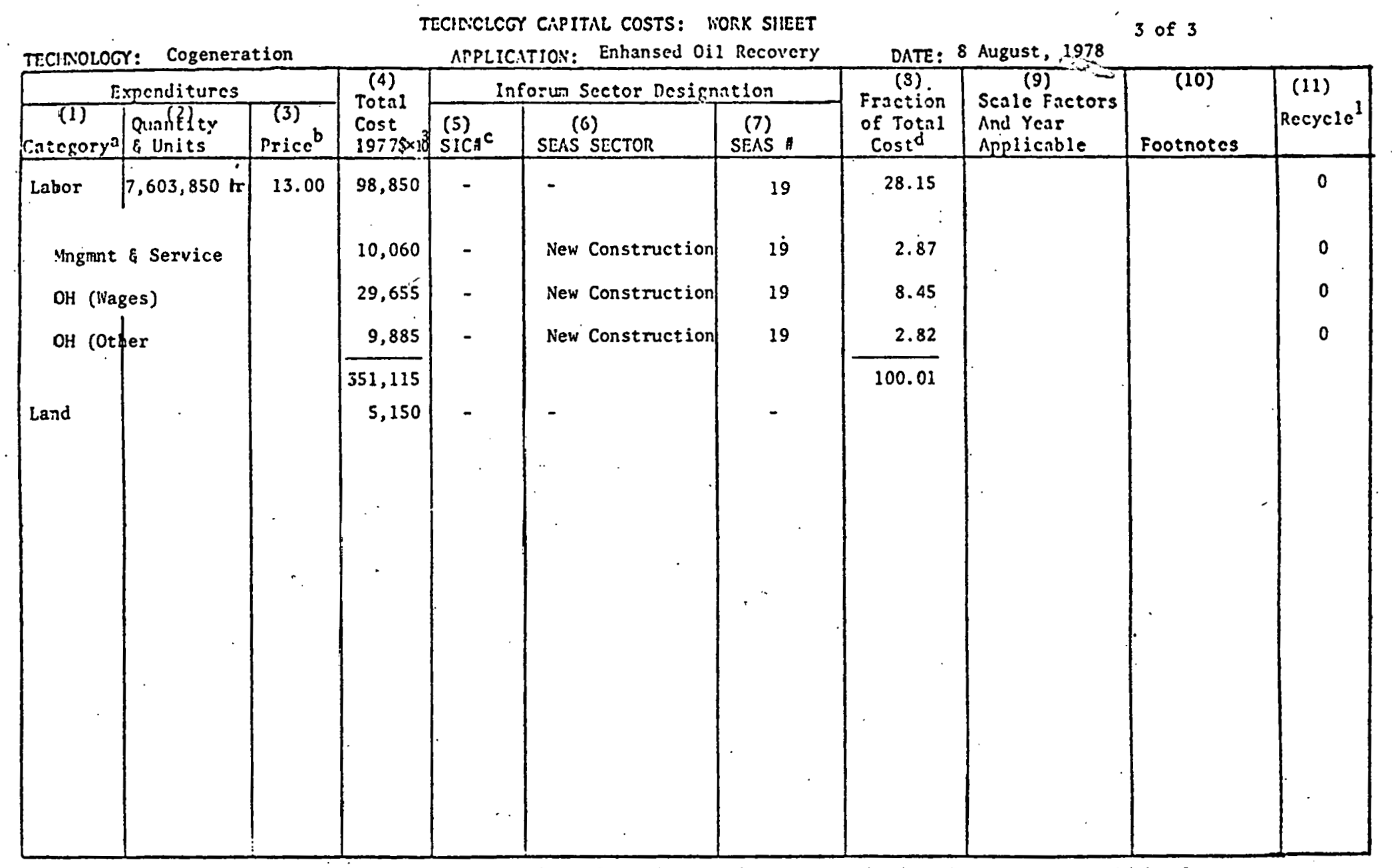

(a) For construction category, indicate the number of man-hours of labor required. (b). Prices should be for 1972. If other prices are used, indicate year. (c) 1967 SIC code. (d) Numbers may not add to totals due to rounding.

$1_{1}=y c s, 2=$ no. Those items not recycled become land residuals, quantities of recycled materials per $102^{1}$ annual Btu output are contained in the 1 ist of 'side equations. 
TECINOLOGY CAPITAL COSTS: HORK SHEET / ANNUAL COSTS

\begin{tabular}{|c|c|c|c|c|c|c|c|c|c|c|}
\hline EINOLOG & Ccge & & & APPLI & ON: Enhanced 0 & covery & DATE: & 21 September 19 & & \\
\hline & xpenditure & & $\begin{array}{c}(4) \\
\text { Tot31 }\end{array}$ & & orun Sector Design & ation & $\begin{array}{c}(S) \\
\text { Fraction }\end{array}$ & (9) & & \\
\hline $\begin{array}{c}(1) \\
\text { Catcgorya } \\
\end{array}$ & $\begin{array}{l}\text { Guantilty } \\
\text { \& Units }\end{array}$ & $\begin{array}{l}\text { (3) } \\
\text { Priceb }\end{array}$ & $\begin{array}{l}\text { Cost } \\
1976 \times 1\end{array}$ & $\begin{array}{l}(5) \\
\text { SIC }\end{array}$ & $\begin{array}{c}(6) \\
\text { SEAS SECTOR }\end{array}$ & $\begin{array}{r}(7) \\
\text { SEAS A } \\
\end{array}$ & $\begin{array}{l}\text { of Total } \\
\text { Cost d (\%) }\end{array}$ & $\begin{array}{l}\text { And Year } \\
\text { Anplicable }\end{array}$ & Footnotes & Recycie \\
\hline v & $\therefore$ & & $\begin{array}{r}740 \\
18,000 \\
150 \\
950 \\
10,100 \\
16,600 \\
200 \\
25,400 \\
12,200 \\
10,600 \\
1,700 \\
1,600 \\
2,700\end{array}$ & $\begin{array}{r}2431 \\
281 \\
321 \\
3293 \\
331,332 \\
3339 \\
3441 \\
3443 \\
3449 \\
\\
3494 \\
\\
3569 \\
3434 \\
3435 \\
3561 \\
3622\end{array}$ & $\begin{array}{l}\text { Mllwork - wood } \\
\text { Industrial Chem. } \\
\text { Gass } \\
\text { Other stone, clay } \\
\text { Iron and steel } \\
\text { Non-Ferrous metal } \\
\text { Fabricated } \\
\text { Structural Met'ls } \\
\text { Fabricated metal } \\
\text { N.E.C. } \\
\text { Pipes, valves, } \\
\text { fitting } \\
\text { Cen: Indus. Equipt. } \\
\text { Naterial handling } \\
\text { EqEipment } \\
\text { Punp, compressor, } \\
\text { Blaver } \\
\text { Control equipment }\end{array}$ & $\begin{array}{r}46 \\
64 \\
86 \\
90 \\
91 \\
96 \\
104 \\
110 \\
109 \\
122 \\
114 \\
119 \\
132 \\
\vdots \\
\vdots\end{array}$ & $\begin{array}{c}0.32 \\
7.77 \\
0.07 \\
0.41 \\
4.36 \\
7.17 \\
0.09 \\
10.97 \\
5.27 \\
4.58 \\
0.73 \\
\vdots \\
0.69 \\
1.17\end{array}$ & $\begin{array}{l}\text { Assumed } \\
\text { Equal to } 1 \\
\text { For all Costs }\end{array}$ & $\because \quad:$ & $\begin{array}{l}0 \\
1 \\
1 \\
1 \\
1 \\
1 \\
0\end{array}$ \\
\hline
\end{tabular}

(a) For construetion category, indicate the nunber of man-hours of labor required. (b) Prices should be for 1972. If other prices are used, indicate year. ( $\Leftrightarrow 1967$ SIC code. (d) Nubbers may not add to totais due to rounding. (e) $1=$ yes, 2 = no. Items not recycled may be considered to be operational residuals. 
TECILOLOGY CAPITAL COSTS: HORK SIIEET /ANNUAL COSTS

2 of 2

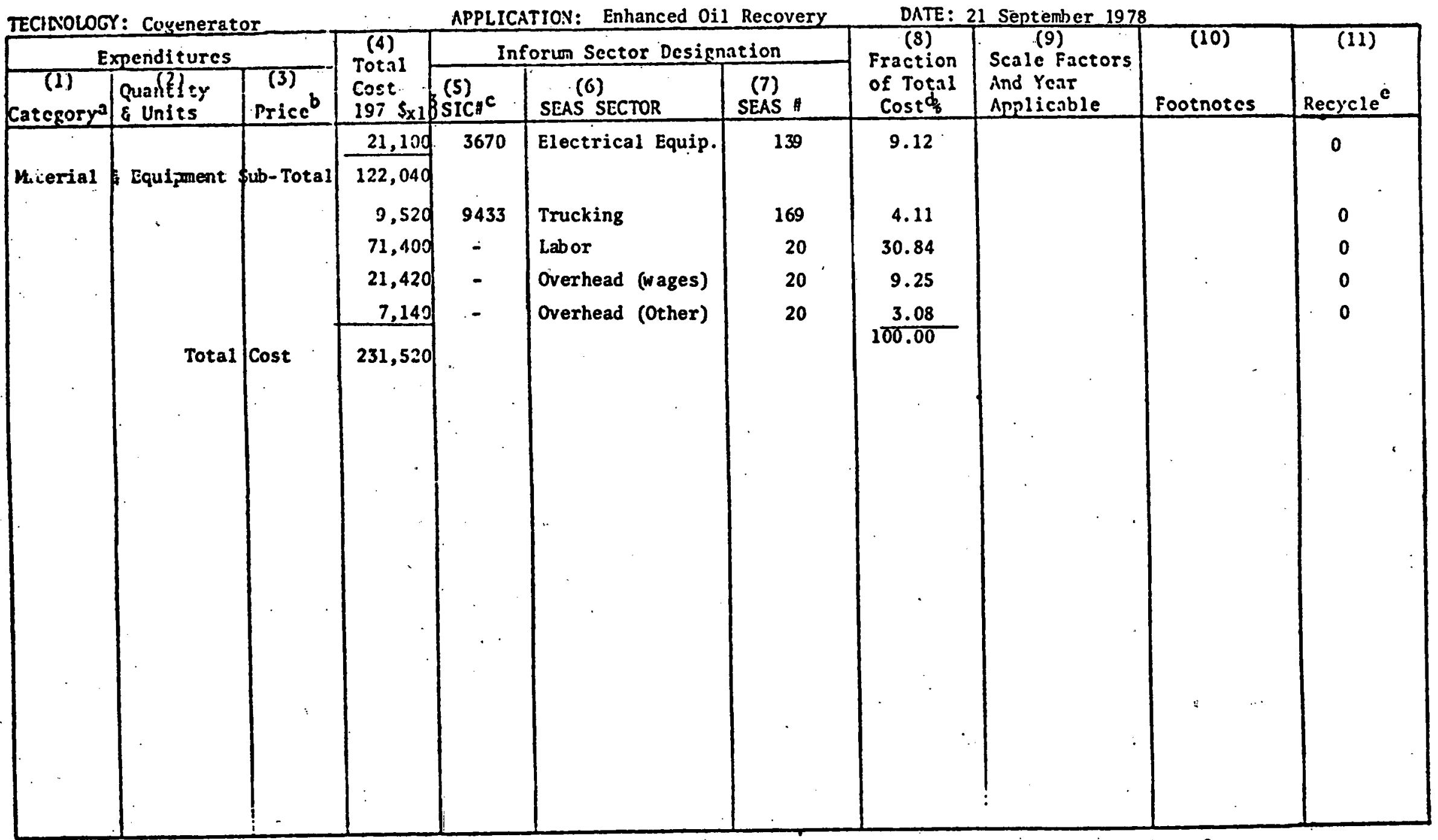

(a) For construction category, indicate the number of man-hours of labor required. (b) Prices should be for 1972. If other prices are used, indicate year. (c) 1967 SIC code. (d) Nubers may not add to totals due to rounding. (e) $1=$ yes, $2=$ no. Items not recycled may be considered to be operational residuals. 


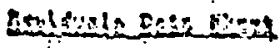

$45+25$

Tpromien Cogenerstion:

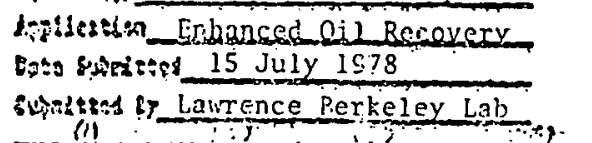

Lowl of Regiftallestsest

Solsonal

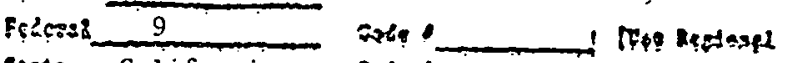

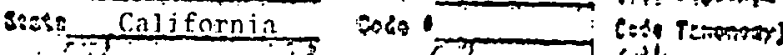

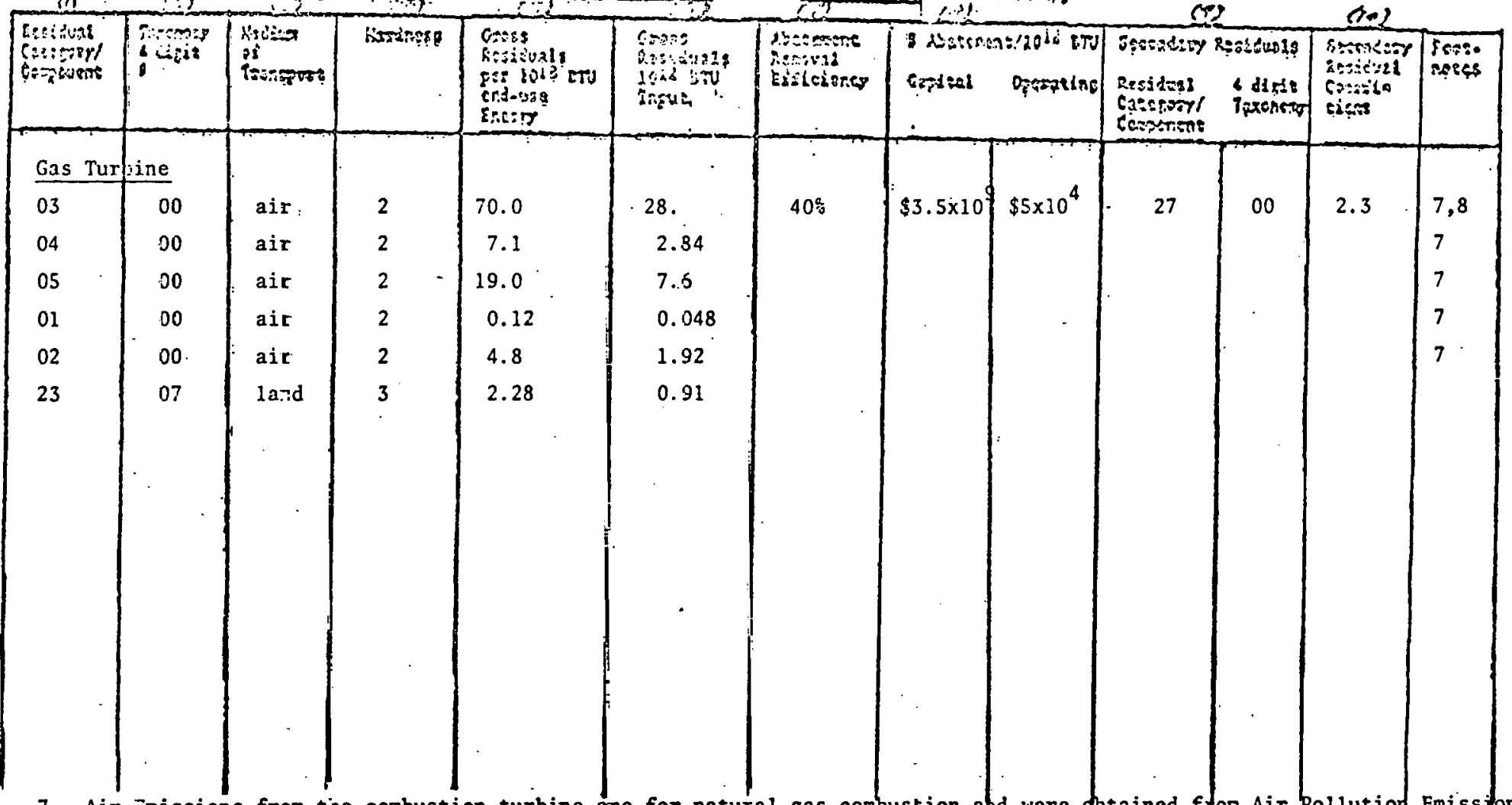

7. Air Imissions fron tie combustion turbine are for natural gas combustion ahd were dbtained flon Air Pollution Emission Factors, EPA publication \#AP-42. Note that the energy output used in this calculation includes the oil marketed which does not get burned in the turbine.

8. Balziniser, Richar.1, "R\&D Status Report: NO Control Technology" EPRI Journäl, $2(X 5): 43$, April 1977. 


\section{APPENDIX B}

CHARACTERIZATION OF MUNICIPAL SOLID WASTE (MSW)

AND MSW CONVERSION TECHNOLOGIES

The concept of MSW energy and resource recovery was presented in the Introduction section of this report. This appendix will characterize the input municipal solid waste, will briefly contrast energy and resource recovery with landfill systems, and will expand on the description of general MSW recovery systems provided in the Introduction section.

Conceptual Comparison of Landfill and Recovery

Approximately 600,000 tons of solid wastes are generated daily within commercial, residential and industrial sectors in the United States. By the most common current practices, these wastes are collected at the site of generation by two- and four-ton trucks, hauled to a central transfer station, compacted, loaded on to large (10-ton) transfer trucks and hauled to a landfill site. National average costs for this type of operation range from $\$ 4$ to $\$ 8$ per ton and may be approximated by the following regression equation (Nuss et al., 1975):

$$
C_{L F}=2.35+Q 96(L)
$$

where

$$
\begin{aligned}
C_{L F} & =\text { cost of collecting and landfilling one ton of MSW } \\
2.35 & =\begin{array}{l}
\text { national average haul cost (includes collection, } \\
\text { transfer and haul) }
\end{array} \\
L & =\text { landfill land costs }(\$ 1000 / \text { acre) }
\end{aligned}
$$

In addition to variations in land costs, $C_{L F}$ varies significantly as a function of the deviation of haul costs from the national norm. For example, in San Francisco, California, where both land costs are high and haul distances are long (approximately 30 miles), the actual haul cost is approximately $\$ 10$ per ton and the total cost is approximately $\$ 16$ per ton (California Solid Waste Management Board, 1977). In many 
locations waste incineration is added to this process before the haul to a landfill as a weight and volume reduction measure.

As a alternative to direct landfill disposal, a variety of resource recovery schemes are currently being investigated. In general these schemes convert a certain portion of the solid waste stream combined with varying amounts of additional input energy into usable energy or energy fuel, basic recoverable' resources, an air pollution stream, a water poliution stream, and a substantialiy reduced solid waste stream. While resnurce recovery proccsses can recover energy resources and valuable recyclable resources (irnn, aluminum, glaso and paperi) and do substantially reduce landfill requirements, they also generate these pollutant flows released into the atmosphere and into municipal water systems. General schematic diagrams for a landfill system and for an energy and resource recovery system are shown in Figure $B-1$. This figure shows the basic categories of inputs and outputs associated with each system and qualitatively compares them. A positive rating ( + ) indicates that the use of or generation of that category on that system is preferable (provides a net benefit) relative to the other system. As is evident, energy and resource recovery systeins provide significant benefits by producing energy and recyclable materials and by reducing landfill operations and land requirements for landfill. However, several significant additional costs are also incurred. Aquatic and atmospheric pollutants are generated and large initial capital investments are required.

In addition to the qualitative systemic comparison shown in Figure B-1, a determination to shift from landfill to a resource recovery system involves a wide spectrum of technical, engineering, social and institutional issues not depicted in Figure B-1. As examples, these include the staty-of-thc-art of the vartous technologies (will it work?), the question of public or private ownership and operation, the financing and marketing of the facility and its products, and the municipal organization required to adequately support and promote the facility. To emphasize the last issue, Bartolatta (1975) stated that the principal difference between resource recovery facilities and other municipal facilities and operations is the unique organization required to finance and operate the facility and competitively market the products. 
A. Landfill System

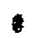

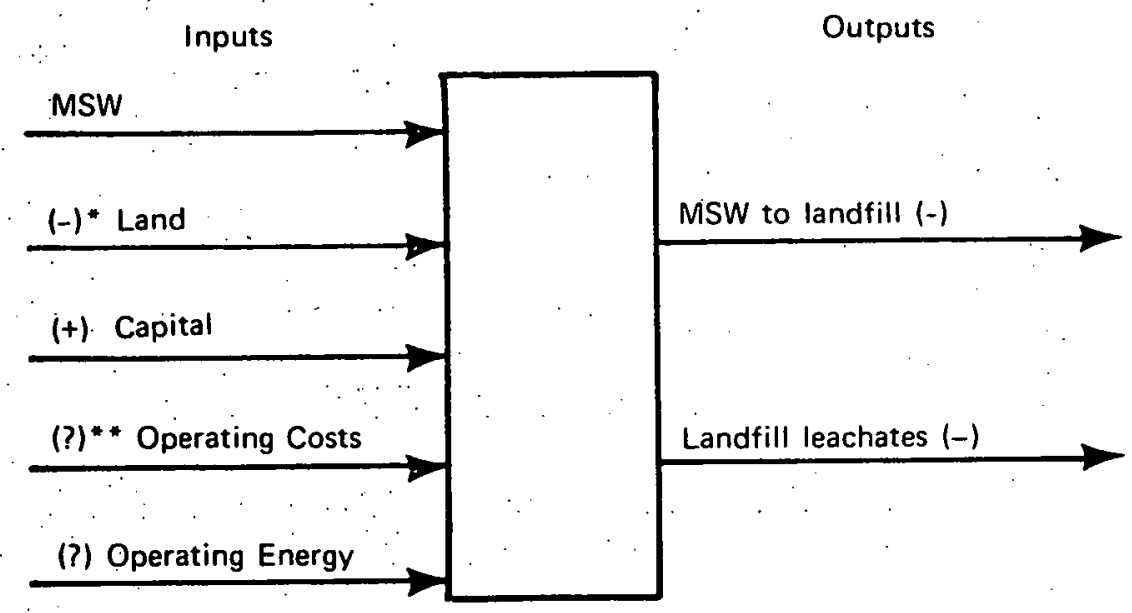

B. Energy and Resource Recovery System

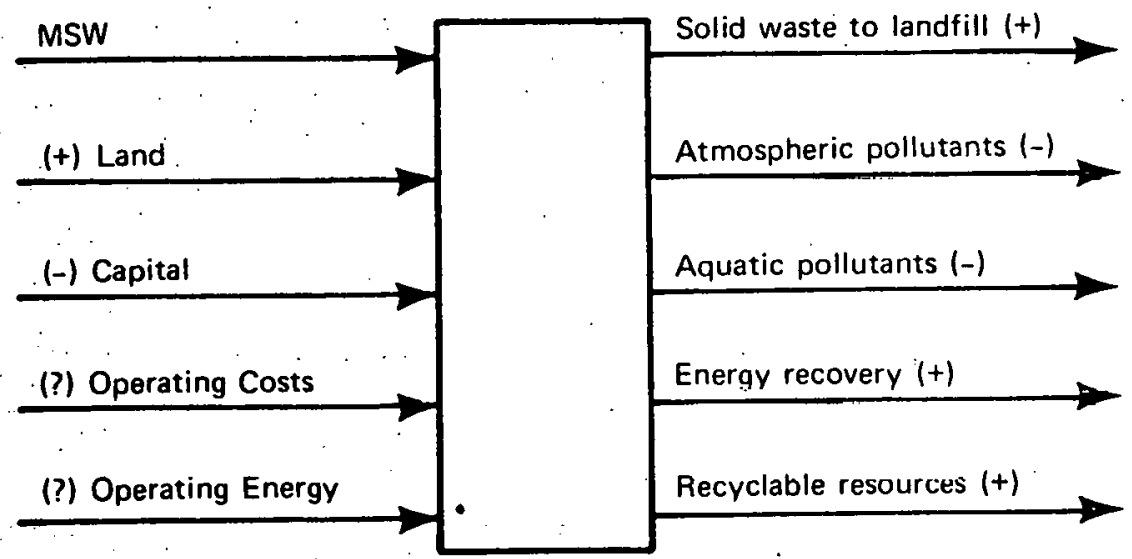

" $(-)$ indicates a less desirable parameter value than with the opposing Thus, land is (-) for landfill systems as more land is required for these systems than for Resource Recovery Systems.

**(?) indicates that neither system has a clear, consistent advantage.

XBL $7810-11658$

Fig. B-1. Systemic Schematics for a Landfill and for a Resource Recovery Sy3tcm 
Thus the shift toward energy and resource recovery systems involves complex, long-term economic analysis, environmental tradeoff analyses, institutional adjustments, and risk analyses both for the new emerging technologies, for future MSW supply and composition, and for future product market conditions. While the local importance of one factor in this analysis (such as stringent atmospheric discharge standards or a lack of available land for landfil1s) may dominate the decision making considerations between these two general types of solid waste disposal systems in some communities, for many others the many individual costs and benefits associated with resource recovery systems must each be addressed and analyzed.

Characterization of Municipal Solid Waste

- Municipal Solid Waste is that waste collected on a routine basis from the residential and commercial sectors within a populated area. In general MSW does not include either industrial solid wastes or agricultural solid wastes as these are typically segregated from residential and commercial wastes through a separate collection and processing system (Kaiser, 1967; West Virginia University, 1976). It should also be noted that at the rates of production considered for energy recovery, MSW is a product of urban rather than rural areas.

A large number of studies have analyzed the rate of production and composition of urban residential and commercial wastes for individual communities. The rate of production of MSW, as characterized by these studies, varies from a low of 2.75 to 3 pounds per day per person (Stephens, 1925; Golueke and McGaukey, 1976) to a high of 4.5 to 5 pounds per. day per person (Wilson, 1971; Mathematical Sciences Northwest, 1974; Levy, 1975). To approxillale the mean of all studies, a value of four pounds per person per day, is used which can act as a good "ballpark" rate of production for planning purposes. Several studies (e.g. Quimby, 1975 or Golueke and McGanhev. 1976) have suggested MSW Iroduction rates have increased over time on a per capita basis. However, this increase is slight and is not included here. 
The composition of MSW has also been well studied and is of greater importance than the rate of production for energy and resource recovery. Table B-1 shows the composition of MSW by major material components as reported by the indicated selected studies. Several of the annual average percentage values shown in Table B-1 (e.g. yard wastes) are, in fact, highly variable over a one-year period. The high variance in percent composition of paper goods results, in part, from source separation of paper goods practiced in some but not all communities. Table B-2 shows the basic chemical composition of MSW reported for the same general group of studies. Of particular interest to this study is the energy content of MSW. The mean energy content of MSW in the reported studies is $9.08 \times 10^{6} \mathrm{Btu} / \mathrm{ton}$. The variance between any specific sample and this mean value can be significantly higher than that shown in Table B-2 as Table B-2 data are on time-averaged values and thus do not reflect either variations over the year or spatial variations (e.g. central city and suburban collections). It should be noted that, while significant between samples were found over time of year and size of community, significant regional variations were not found.

The analysis by Wilson (1971) suggests that the methods used to. calculate heat content tend to significantly underestimate actual heat content and that values of $1.4 \times 10^{7} \mathrm{Btu}$ to $1.8 \times 10^{7} \mathrm{Btu}$ per ton are more accurate. The use of approximately $9 \times 10^{6} \mathrm{Btu} / \mathrm{t}$ on as a mean MSW heat content would then represent a somewhat conservative estimate of heat input and thus an overestimate of overall system efficiency. However, the preponderance of available information suggests that $9 \times 10^{6} \mathrm{Btu} /$ ton to $9.1 \times 10^{6} \mathrm{Btu} /$ ton is as reasonable an estimate as can be made.

The nomographs shown in Figure B-2 provide a simple means of assesing the impact of the use of average rates of production and MSW energy content (or of actual local variations from these means) on the total energy supplied to the MSW energy recovery process. Starting with the lefthand scale of Figure B-2 for the example shown, a generation rate of $4 \mathrm{lb} /$ person/day and a local population of 200,000 are connected with a straight line which is extended to the center scale to determine total local MSW generation rate. This point is then connected with the assurned 
Table $8-1$

NSW Mazcrial Conponent's from Various Studies

\begin{tabular}{|c|c|c|c|c|c|c|c|c|c|c|c|c|c|c|c|}
\hline Source & $\begin{array}{c}\text { Year } \\
\text { Anslyzed }\end{array}$ & Paper & Glass & $\begin{array}{l}\text { Metal } \\
\text { Total }\end{array}$ & $\begin{array}{c}\text { (Ferrous } \\
\text { Netal) }\end{array}$ & (Aluminum) & (Other) & Plastic & $\begin{array}{l}\text { Rubber } \\
\text { and } \\
\text { Leather }\end{array}$ & Textiles & Wood & Food & Wastes & Misc. & Total \\
\hline US EPA, 1976 & 1972 & $31 . \varepsilon$ & 10.1 & 9.5 & $\left(8.5^{\circ}\right.$ & $(0.7)$ & $(0.3)$ & 3.5 & 2.6 & 1.5 & 3.6 & 17.0 & 18.9 & 1.5 & 100 \\
\hline US EPA, 1977 & 1975 & 30.6 & 10.5 & 9.6 & ( 8.5: & $(0.8)$ & $(0.3)$ & 4.1 & 2.7 & 1.5 & 3.7 & 16.7 & 19.1. & $1.5^{\circ}$ & 100 \\
\hline W. Virgina Univ. & 1975 & 48.0 & 14.0 & 8.0 & & . & . & 1.1 & 0.9 & 1.0 & 2.0 & 16.0 & $9.0^{\circ}$ & & 100 \\
\hline $\begin{array}{l}\text { CA State Solid } \\
\text { Waste Board, } 1976\end{array}$ & Average & 46.0 & 9.6 & 7.5 & $\left(6.0^{\circ}\right.$ & $(1.0)$ & $(0.5)$ & 2.1 & 2.1 & 2.1 & 4.2 & 6.4 & 20.0 & & 100 \\
\hline $\begin{array}{l}\text { CA State Solid } \\
\text { liaste, Mgmt. } \\
\text { Board, } 1977\end{array}$ & Average & 33.0 & 10.0 & 9.5 & ( 8.0: & $(0.8)$ & $(0.5)$ & 3.5 & 4.0 & 2.0 & 4.0 & 14.5 & 17.5 & 2.0 & 100 \\
\hline Preston, 1975 & $19 ? 4-75$ & 41.5 & 7.6 & 8.1 & ( 7.0: & $(0.7)$ & $(0.4)$ & 2.3 & $2 . \dot{5}$ & 1.1 & 2.0 & 14.0 & 19.1 & 1.8 & 100 \\
\hline Levy', 1975 & Average & 35.5 & 8.2 & 13.4 & $(12.0)$ & $(1.0)$ & $(0.4)$ & 2.2 & 2.9 & 1.8 & 2.0 & 14.5 & 18.5 & $1.0^{\circ}$ & 100 \\
\hline Sussman, 1974 & Average & 38.0 & 10.0 & 10.0 & $(8.0)$ & $\cdot(1.0)$ & $(1.0)$ & 4.0 & 3.0 & 2.0 & .4 .0 & 14.0 & 14.0 & 1.0 & 100 \\
\hline Kaiser, 1967 & Average & 41.9 & 10.3 & 8.3 & & . & . & 3.1 & 0.9 & 2.6 & 3.1 & 12.2 & 17.5 & & 100 \\
\hline Cho, 1975 & $19: 2-74$ & 44.9 & 13.05 & 12.9 & . & & .. & 4.1 & $i .2$ & 3.2 & $2.2 \therefore$ & $10_{i} 9$ & $6.45:$ & 1.1 & 100 \\
\hline Livingston, 1976 & Average & 38.0 & 10.0 & 10.0 & $(8.0)^{\circ}$ & $(1.0)$ & $(1.0)$ & 4.0 & 3.0 & 2.0 & 4.0 & 14.0 & $14: 0$ & 1.0 & 100 \\
\hline US EPA, $1976 \mathrm{a}$ & Average & 34.9 & 10.5 & 9.8 & $(8.6)$ & $(0.8)$ & $(0: 4)$ & 3.8 & 2.6 & $1.7:$ & 3.8 & 14.9 & 16.3 & 1.6 & 100 \\
\hline Lawler, 1975 & Average & 43.0 & 8.0 & 8.5 & $(7.0 \%$ & $(1.0)$ & $(0.5)$ & 2.0 & 2.0 & 2.0 & $3: 0$ & 15.0 & 13.0 & 3.5 & 100 \\
\hline $\begin{array}{l}\text { Schnelle and } \\
\text { Yamamoto, } 1975\end{array}$ & Average & 44.2 & 8.5 & 8.7 & $\because$ & & & 1.8 & 1 & 2.3 & 2.5 & 16.6 & 12.6 & 1.7 & 100 \\
\hline Mean & & $39.4 \mathrm{~L}$ & 10.02 & 9.55 & $(8.16)$ & $(0.88$ & $(0.53)$ & 2.96 & 2.25 & 1.91 & 3.14 & 14.05 & 15.43 & $1.29^{\circ}$ & $\therefore$ \\
\hline $\begin{array}{l}\text { Standard } \\
\text { Deviation }\end{array}$ & . & $5.6 \mathrm{t}$ & 1.78 & 1.72 & 1.58 & 0.13 & 0.26 & 1.02 & 0.93 & $\begin{array}{ll} & 0,57 \\
\ddots & \ddots\end{array}$ & $\begin{array}{c}0.86 \\
\because \quad \therefore \\
\end{array}$ & $\begin{array}{c}2.77 \\
\therefore \\
\end{array}$ & 4.10 & 0.90 & \\
\hline
\end{tabular}


Table B-2

MSW Chemical Composition from Various Studies

\begin{tabular}{|c|c|c|c|c|c|c|c|c|c|c|c|c|}
\hline Source & $\begin{array}{l}\text { Btu } \\
\text { Per } \\
\text { Ton } \\
\left(10^{6}\right)\end{array}$ & Organics & Moisture & Ash & Glass & Al & $\mathrm{Fe}$ & $\because \mathrm{S}$ & N & 0 & $\mathrm{C}$ & $\mathrm{H}$ \\
\hline $\begin{array}{l}\text { W. Virginia, } \\
1976\end{array}$ & 9.2 & & & & & " & & 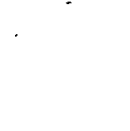 & & & 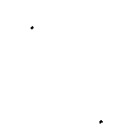 & \\
\hline $\begin{array}{l}\text { Sessler \& Cuha, } \\
1975\end{array}$ & 9.1 & & 25.0 & 8.5 & 8.0 & 0.4 & 6.0 & 0.1 & 0.4 & 24.0 & 24.4 & 3.2 \\
\hline Preston, 1975 & 9.5 & 52.0 & 25.0 & & & & & & & . & & \\
\hline Lẹvy, 1975 & 9.2 & 52.0 & 25.0 & & . & & & & & & & \\
\hline Sussman, 1974 & & 53.0 & 21.0 & 9.0 & 8.0 & & 7.0 & 0.3 & 0.7 & 24.0 & 25.0 & 3.0 \\
\hline Kaiser, 1967 & 8.2 & & 33.0 & 12.6 & & 1.0 & 8.4 & 0.08 & 0.5 & 18.0 & 22.0 & 2.9 \\
\hline Cho, 1975 & 8.8 & & 25.5 & 6.0 & 12.1 & 0.8 & 7.9 & 0.1 & 0.5 & 18.9 & 24.7 & 3.3 \\
\hline $\begin{array}{l}\text { Livingston, } \\
1976\end{array}$ & 9.5 & & 21.0 & 10.0 & 9.0 & 0.5 & 6.5 & 0.3 & 0.7 & 24.0 & 25.0 & 3.0 \\
\hline $\begin{array}{l}\text { Schenelle \& } \\
\text { Yamamoto, } \\
1975\end{array}$ & 9.4 & & 25.0 & $=$ & 9.0 & 1.0 & & 0.1 & 0.58 & 22.08 & 26.18 & 3.51 \\
\hline Mean & 9.08 & 52.5 & 24.57 & 9.22 & 9.28 & 0.72 & 7.06 & 0.17 & 0.56 & 21.40 & 24.38 & 3.08 \\
\hline $\begin{array}{l}\text { Standard } \\
\text { Deviation }\end{array}$ & 0.59 & 0.58 & 4.00 & 2.40 & 1.94 & 0.27 & 0.11 & 1.13 & 3.06 & 1.26 & 1.26 & 0.16 \\
\hline Variance & 0.22 & 0.25 & 13.74 & 4.59 & 2.83 & 0.06 & 0.78 & 0.61 & 0.01 & 7.47 & 1.28 & 0.02 \\
\hline
\end{tabular}




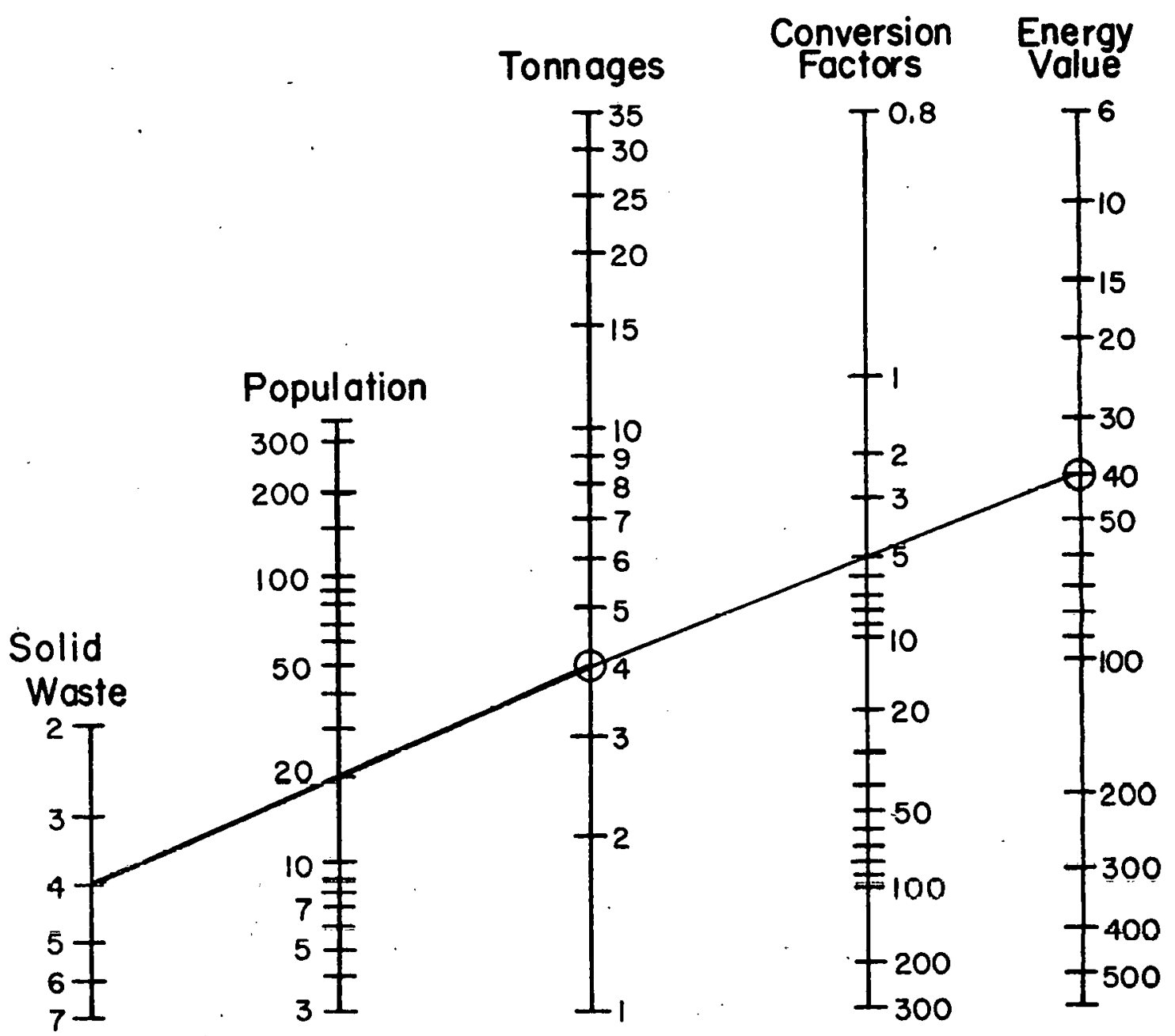

LB/day POP $10^{4}$ TONS/day $10^{2}$ Btu's $/ \mathrm{lb} 10^{3}$ Btu's/day $10^{8}$ $\mathrm{KWH} / 10^{4 *}$, Therm $10^{3}$

${ }^{*}$ Assumes $30 \%$ conversion efficiency in electrical generating plant. XBL $7810-11648$

Fig. B-2. Nomograph for Calculation of Total Energy Value of MSW (from California State Solid Waste Management Board, 1976) 
heat content $\left(5 \times 10^{3} \mathrm{Btu} / \mathrm{lb}\right.$ or $10 \times 10^{6} \mathrm{Btu} /$ ton as used in this example) and extended to the far right scale to find total heat content of the MSW in Btu/day.

\section{General Characterization of MSW Energy Recovery Systems}

All of the MSW energy recovery systems which are addressed in this study follow the general schematic shown in Figure B-3. As used here, front end systems are those involved with the preparation of MSW for an actual recovery process (energy recovery or resource recovery), while rear end systems perform the transformation of MSW into an energy product. Conversion systems are used to convert a basic energy product into some other energy end use form. It is generally true that the selection of a given process or set of processes within one box on Figure B-3 does not restrict the choice of processes in subsequent boxes. Thus, a wide variety of specific facility designs are possible with each being tailored to local characteristics and requirements.

Figure B-4 shows the general Resource Recovery Module in greater detail. The processes and products listed on Figure B-4 are typical of most MSW resource recovery systems and are used in this study as a standard design for all energy recovery systems. The selection of specifiç components for this module does not affect the outcome of the energy recovery systems except by varying facility total capital requirements and operatinnal auxilliary energy requirements. This resource recovery system does not include paper recovery nor is it based on a analysis to maximize profitability or to ensure net energy efficiency of the recovered material. Rather, this portion of the total MSW recovery system is based on the most common on-line technology in U.S. plants.

l'able B-3 lists the major categories of residuals associated with the operation of one or more of the MSW energy recovery systems. Not ali pollutant flows listed on Table B-3 are produced by each MSW energy recovery technology. However, the potential for this spectra of residuals should be systematically assessed for each step within an MSW recovery process. 


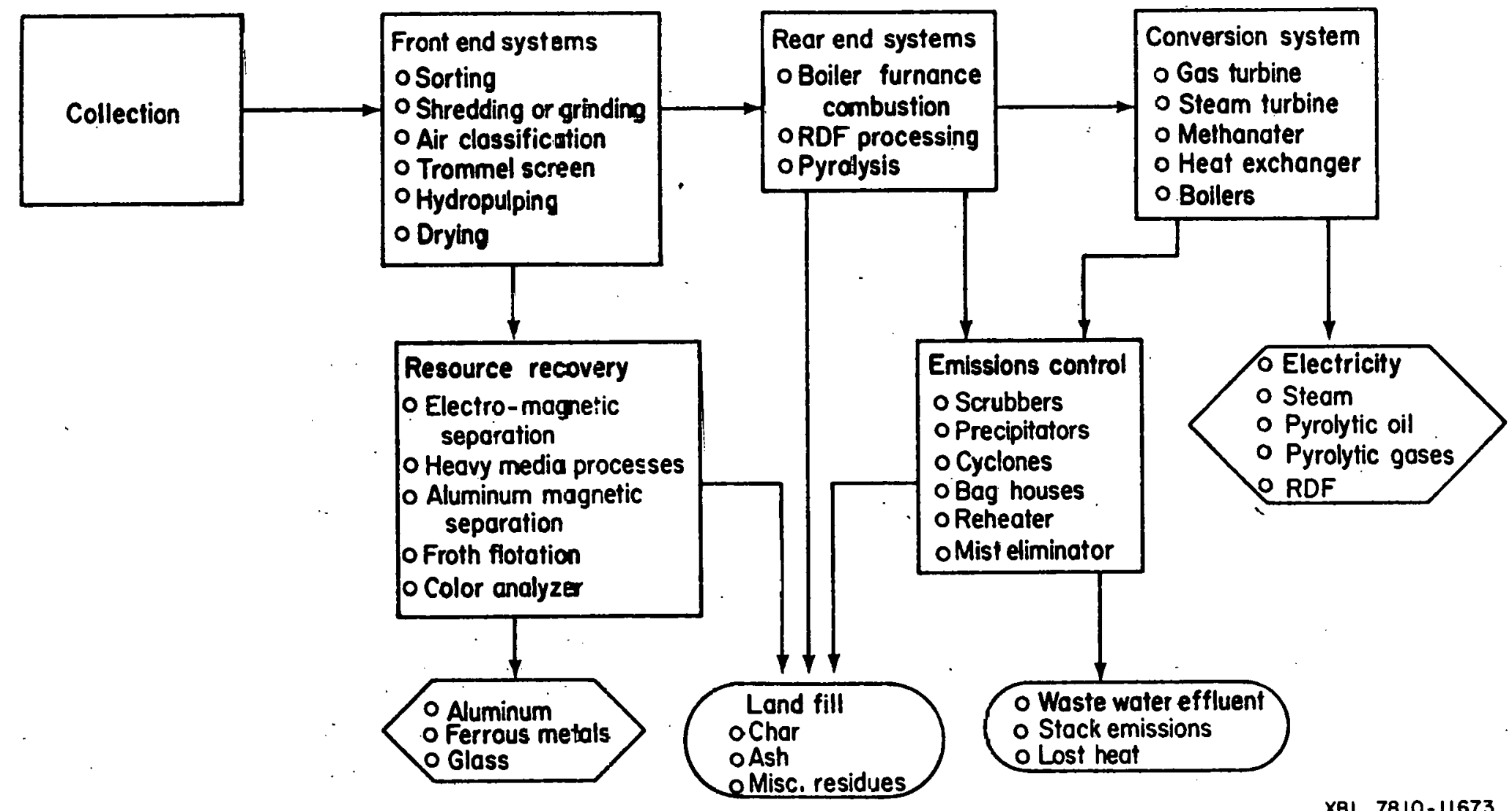

Fig. B-3. Municipal Solid Naste Resource Recovery 


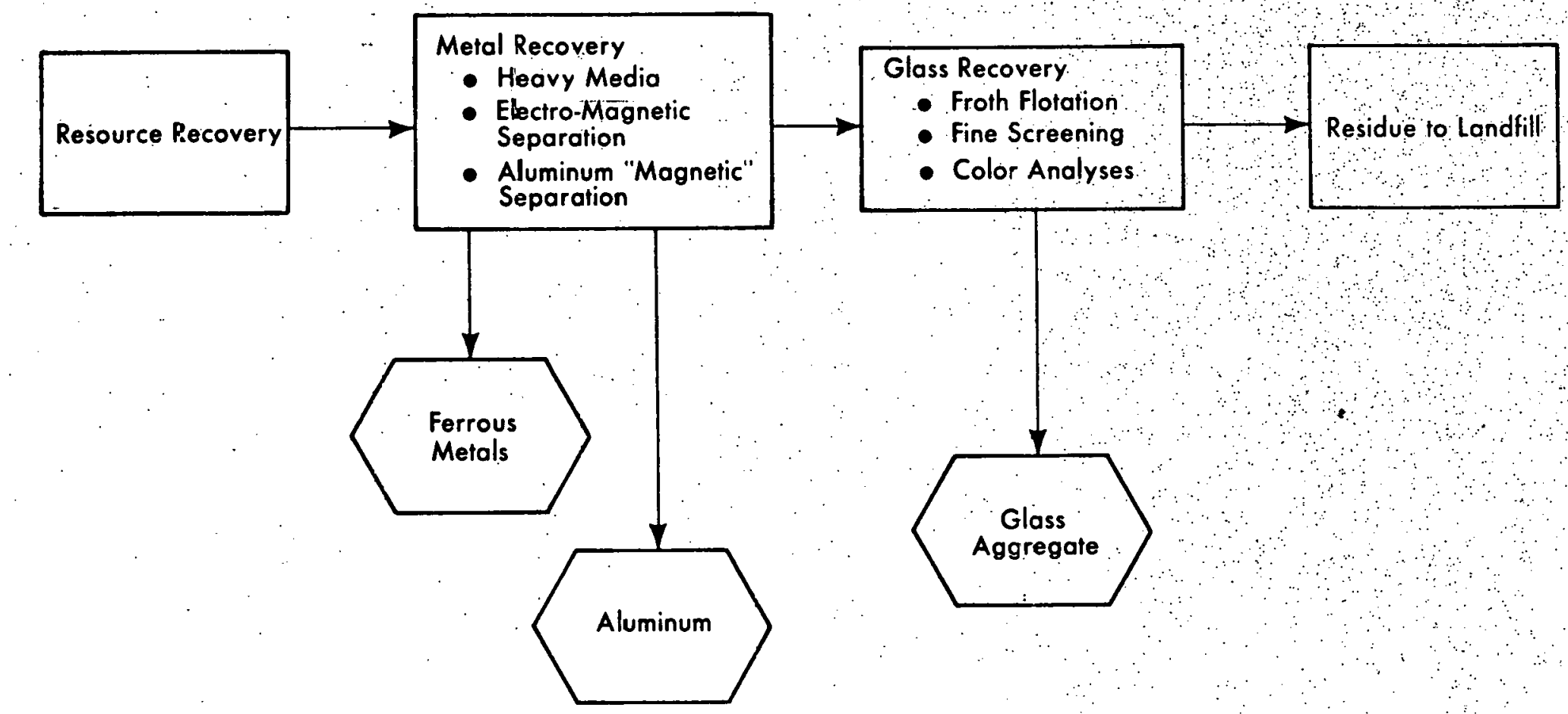


Table B-3

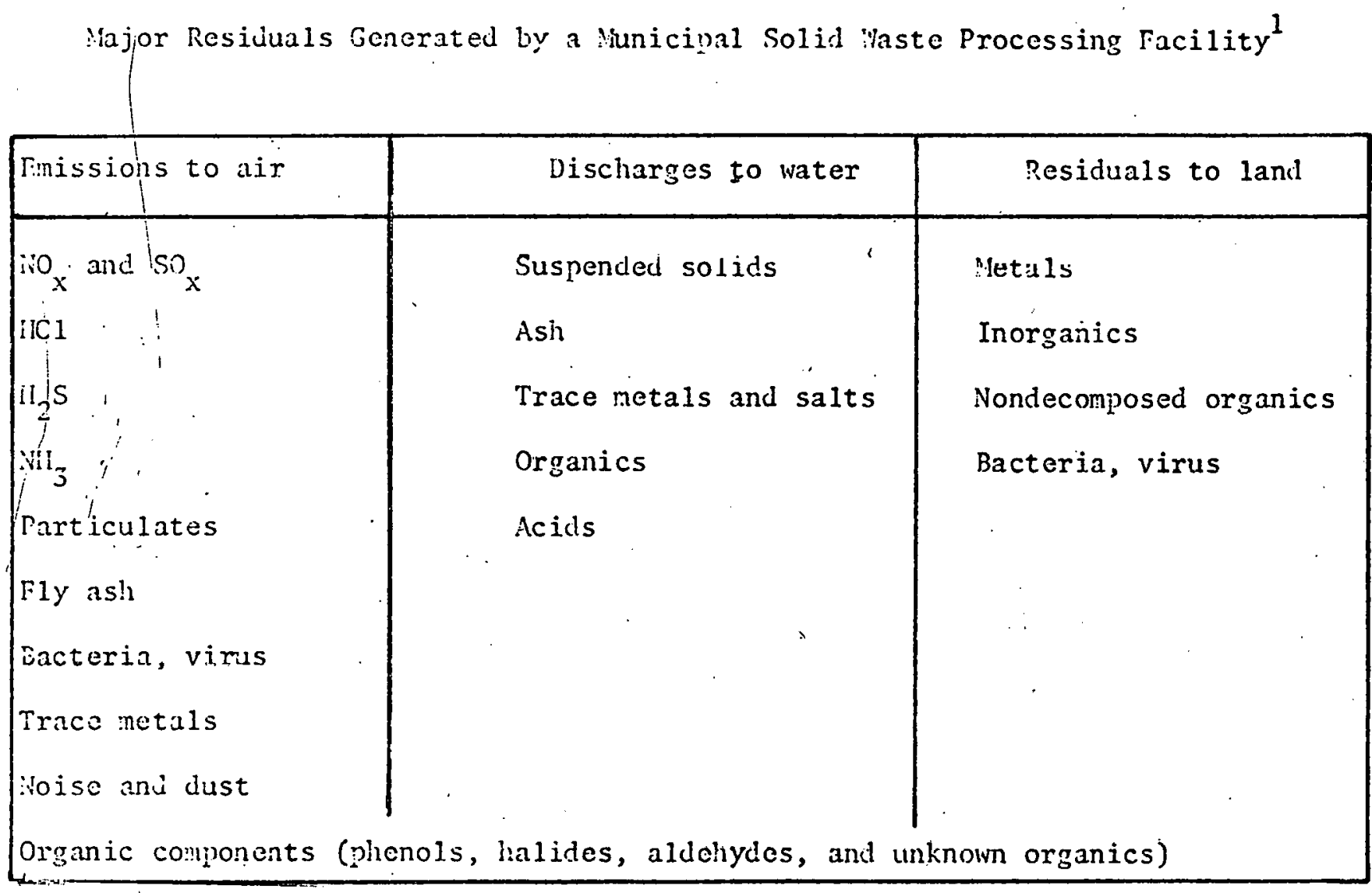

${ }^{1}$ From Aerospace Corp., 1975 and 1976. 
REFERENCES : APPENDIX B

The Aerospace Corporation, Energy Systems Environmental Control Technology Planning Survey, ATR-76(7518-1), 1975 .

The Aerospace Corporation, Energy Recovery from Municipal Solid WastesAn Environmental and Safety Mini-Overview Survey, AT12-76 (7518-7), 1976.

'Bartolotta, R.J., "Resource Recovery: Possibilities and Pitfalls," Solid Wastes Management, November 1975.

Cho, P. and F.H. Sanneman' Supplémenting Fuel Processing P' 'lant for Chicago, Illinois, U.S. Federal Energy Administration, 1975.

California State Solid Waste Manágement Board, Resource Recoveryi Program: Volume II Unabridged Report, 1976.

California State Solid Waste Management Board, Refuse to Energy Conversion Project, December 1977.

Golueke, C.G. and.P.H. McGauhey, "Waste Materials," in Annual Review of Energy, Volume 1, Energy Resources and Development Administration, 1976.

Kaiser, E.R., "Composition and Combustion of Refuse," in (R. Fox, editor) Proceedings of Mecar Symposium-Incineration of Solid Wastes, ASME Incineration Committee, 1967.

Lawler, S.P., "The Americology System (Milwaukee)," in (S.M. Barrett et al., editors) Energy from Solid Waste Utilization, Proceedings of the Sixth Annual Northeastern.Regional Anti-Pollution Conference, 1975.

Levy, S.J., San Diego County Demonstrator of Pyrolysis Solid Waste, Prepared for U.S. Environmental Protection Agency, 1975.

Livingston, R.A., "Energy from Solid Waste," , Environmental Aspects of NonConventional Energy Sources, Transaction of ANS Meeting, 29 February to 3 March 1976

Mathematical Science Northwest, Inc., Feasibility Study-Conversion of Solid Waste to Methanol or Ammonia, $197 \overline{4}$.

McEwan, L. and S. Levy, "EPA Tracks Progress of Facilities Implementing Resource Recovery," Solid Wastes Management, March 1977.

Nuss, G.R. et al., Base Line Forecasts of Resource Recovery, 1972-1990, Midwest Research Institute, U.S. EPA Publication No. SW-1076, 1975.

Preston, G.T., "Resource Recovery and Flash Pyrolysis of Municipal Refuse," Presented tothe Institute of Gas Technology Symposium on Clean Fuels from Biomass, Sewage, Urban Refuse and Agricultural Wastes, January 27, 1976.

Quimby, T.H., Recycling: The Alternative to Disposa1, Baltimore, MD: The Johns Hopkins University Press, 1975.

St. Clair, W., "Resource Recovery-A Review," Waste Age, June 1975.

Schnelle, J.F. and J.H. Yamamoto, "Potential Alternative Fuels Derivatives from Municipal Solid Waste," in (S.M. Barnett et al, editor) Energy from Solid Waste Utilization, Proceedings of the Sixth Annual Northeatern Regional Anti-Pollution Conference, 1975. 
REFERENCES: APPENDIX B (continued)

Stephens, R.H., "Sream Recovery-An Alternative for Intermediate Size Regions," in (S.M. Barnett et al., editors) Energy from Solid Waste Utilization, Proceedings of the Sixth Annual Northeastern Regional Anti-Pollution Conference, 1975.

Sussman, D.B., Baltimore Demonstrates Gas Pyrolysis-The Energy Recovery Solid Waste Facility in Baltimore, Maryland, Prepared for the U.S. Environmental Protection Agency, 1974.

U.S. Environmental Protection Agency, Decision-Makers Guide in Solid Waste Management, Offire of Solid Waste Mallalement, Publication No. SW-500, 1976.

U.S. Environmental Protection Agency, Resource Recovery Plant Implementation Guide for Municipal officials-Technology, U.S. EPA Publication No. SW-157.2, 1976a.

U.S. Environmental Protection Agency, Fourth Report to Congress: Resource Recovery and Waste Reduction, Office of Solid Waste Management, Publication No. SW-600, 1977 .

West Virginia University, Solid Waste-A New Natural Resource, Department of Chemical Engineering, 1971.

Wilson, D.L., Determination of Heat of Combustion of Solid Wastes from Ultimate Analysis, U.S. Enviironmental Protection Agency, Office of Research and Monitoring Solid Waste Research, Open File Report (RS-0368-17), 1971. 
APPENDIX C

CURRENT STATUS OF MSW ACTIVITY

This appendix contains three tables which depict various aspects of the present level of national activity in municipal solid waste energy recovery. Table $\mathrm{C}-1$ lists existing MSW energy recovery plants, those which have operated but are not now operational, and future plants for which firm commitments have been made. Table C-2 lists U.S. private companies and public sector agencies involved in the design, research construction or operation of MSW energy recovery facilities. Table C-3 lists existing funded research activity in MSW energy recovery by source of funding. Finally, Table C-4 lists system conversion efficiencies for existing MSW energy recovery systems. 


\section{Table $\mathrm{C}-1$}

Current Operational Activity in USW Fnergy and Resource Recovery ${ }^{1}$

\begin{tabular}{|c|c|c|c|c|c|c|}
\hline Locat ion/Develoiper & Type & Capacity & P'roducts & Start In Date. & $\begin{array}{l}\text { Capital } \\
\text { Cost } \\
\left(10^{3} \$\right)\end{array}$ & $\therefore \quad \cdot$ \\
\hline Nasilville, Th./TVA & wateriva 11 & $760 \mathrm{TPD}$ & stean & $\begin{array}{l}\text { Aug. } 1976 \text { after } \\
\text { system mollification }\end{array}$ & 27,000 & $\begin{array}{l}\text { Enginecring f Emission } \\
\text { problems forced exten- } \\
\text { sive systcin todification }\end{array}$ \\
\hline Saugus, MA/ & waterkall & $1200 \mathrm{TPJ}$ & steam & Nov. 1975 & 35,000 & 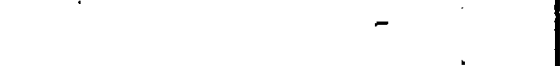 \\
\hline Chicago (NIN), Ill./ & waterwal 1 & 1600 TPD & stean & 1972 & 30,000 & $\begin{array}{l}\text { markct difficulties witl } \\
\text { steam, excessive stack } \\
\text { cmission }\end{array}$ \\
\hline Harrisburg, $\mathrm{Pa} . /$ & waterwal1 & 720 TH & stean & oct. 1973 & $3300^{\cdots-}$ & $\begin{array}{l}\text { marketing stean as of } \\
\text { mid } 1976\end{array}$ \\
\hline Norfolk, Va./ & waterwall & 360 TFD & stean & 1976 & 21.35 & $\begin{array}{l}\text { cost does not include } \\
\text { retrofitted ESP }\end{array}$ \\
\hline Braintrce, ia.! & waterwall & $240 \mathrm{TFD}$ & stean & $\begin{array}{l}1.977 \text { after } \\
\text { modification }\end{array}$ & 2300 & $\begin{array}{l}\text { ESP requircd to meet FPA } \\
\text { enission guidclines: }\end{array}$ \\
\hline Blytheville, Ark./ & $\begin{array}{l}\text { mociular coin- } \\
\text { bustion unit }\end{array}$ & $50 \mathrm{TPH}$ & stem & Nov. 1975 & & : \\
\hline Chicago (SW), I11./ & refractory wall & $1200 \mathrm{TPD}$ & stean & 1963 & & \\
\hline Groveton, N.H. & $\begin{array}{l}\text { modiliar com- } \\
\text { bustion unit }\end{array}$ & $30 \mathrm{TPD}$ & steam & 1975 & & . \\
\hline Nerrick, N.Y. & refractory wall & $600 \mathrm{TPD}$ & electricity. & 1952 &. & \\
\hline
\end{tabular}


........ Table C-1 (continued)

\begin{tabular}{|c|c|c|c|c|c|c|}
\hline Location/Developer & Type & Capacity & Products & Start Up Datc & $\begin{array}{c}\text { Capital } \\
\text { Cost } \\
(10.3 \$)\end{array}$ & Conment \\
\hline Wiani, Ela./ & refractory wall & 900 TPD & steam & 1956 & & \\
\hline Oceanside, N.J./ & $\begin{array}{l}\text { refractory wall/ } \\
\text { watcrwall }\end{array}$ & $750 \mathrm{TPD}$ & steam & $\begin{array}{l}\text { RWI }-1965 \\
\text { INIC }-1974\end{array}$ & . & \\
\hline Sloan Springs, Ark./ & $\begin{array}{l}\text { modular com- } \\
\text { bustion unit }\end{array}$ & $20 \mathrm{TPD}$ & stcaun & Scpt. 1975 & : & \\
\hline Port smouth, Va./ & $\begin{array}{l}\text { waterwal1 } \\
\text { combustion }\end{array}$ & $160 \mathrm{TPD}$ & stcam & Dec., 1976 & & \\
\hline Akron, Ohio/ & $\begin{array}{l}\text { waterwa } 11 \\
\text { combustion }\end{array}$ & 1000 TPD & steam & late 1978 planned & & \\
\hline Haverhil1, $\cdot$ Mass.$/$ & $\begin{array}{l}\text { waterwall } \\
\text { combustion }\end{array}$ & $3000 \cdot$ TPD & electricity & $\mathrm{NA}^{2} \cdot \cdots$ & : & . \\
\hline Jacksonville, Fla./ & $\begin{array}{l}\text { modular com- } \\
\text { bustion unit }\end{array}$ & $50 \mathrm{TPD}$ & steam, iron & WA & & IS Navy plant \\
\hline Lexington, Ky.l & $\begin{array}{l}\text { waterwall } \\
\text { combustion }\end{array}$ & $1050 \mathrm{TPD}$ & steam, iron & NA & & $\because$ \\
\hline Maypors, Fla./ & $\begin{array}{l}\text { refractory wall } \\
\text { incinerator }\end{array}$ & 40 TPD & st eam & NA & & US Navy plant \\
\hline Minneapolis, Minn./ & $\begin{array}{l}\text { waterwall. } \\
\text { combustion }\end{array}$ & 1200 TPD & steam & 1980 & & $\begin{array}{l}\text { steam to support } \\
\text { papermill operation }\end{array}$ \\
\hline New Haven, Conn./ & $\begin{array}{l}\text { waterwa11 } \\
\text { combustion }\end{array}$ & $1800 \mathrm{TPD}$ & steam, iron & NA & & . \\
\hline $\begin{array}{l}\text { North Little Rock, } \\
\text { Ark./ }\end{array}$ & $\begin{array}{l}\text { modular com- } \\
\text { bustion unit }\end{array}$ & 100.TPD & steam & early 1978 & & $\therefore$ \\
\hline
\end{tabular}


Table C-1 (continued)

\begin{tabular}{|c|c|c|c|c|c|c|}
\hline Location/Developer & Type & Capacity & Products & Start Up Date & $\begin{array}{l}\text { Carital Cost } \\
\quad\left(\$ 10^{3}\right)\end{array}$ & Comment \\
\hline $\begin{array}{l}\text { Onondaga County, } \\
\text { N.Y./ }\end{array}$ & $\begin{array}{l}\text { waterwall } \\
\text { conbustion }\end{array}$ & $1000 \mathrm{TPE}$ & stcam, iron & NA & & . \\
\hline $\begin{array}{l}\text { Lenlo Park, Ca./ } \\
\text { Combustion Power } \\
\text { Co. (CPU 400) }\end{array}$ & $\begin{array}{l}\text { direct conbus- } \\
\text { tion }\end{array}$ & $90 \mathrm{TPE}$ & $\begin{array}{l}\text { electricity, } \\
\text { glass, ferrous } \\
\text { and non-ferrous } \\
\text { netals }\end{array}$ & $\begin{array}{l}1976-1977 \\
\text { System test in } \\
\text { conducted }\end{array}$ & & $\begin{array}{l}\text { Emission control and } \\
\text { operational problems } \\
\text { when onerating with :ISw }\end{array}$ \\
\hline $\begin{array}{l}\text { US Recycle Corp. } \\
\text { (Consumat)/ }\end{array}$ & $\begin{array}{l}\text { direct } \\
\text { combustion }\end{array}$ & $\begin{array}{l}12-25 \text { TPD } \\
\text { modules }\end{array}$ & stean & $\cdots$ & & $\begin{array}{l}\text { many now in commercial/ } \\
\text { industrial use }\end{array}$ \\
\hline $\begin{array}{l}\text { Los Angeles, Ca./ } \\
\text { Wat son Energy } \\
\text { Syst cms }\end{array}$ & $\begin{array}{l}\text { waterval I } \\
\text { combustion }\end{array}$ & $1000 \mathrm{TPD}$ & stean & NA & 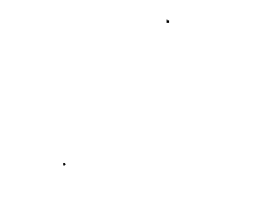 & $\begin{array}{l}\text { steam to be used in } \\
\text { refinery operations. } \Lambda \\
\text { Awaiting atmosnheric } \\
\text { emissions permits }\end{array}$ \\
\hline $\begin{array}{l}\text { Weber, Utah/Clean } \\
\text { Air, Inc. }\end{array}$ & $\begin{array}{l}\text { waterwall } \\
\text { combustion }\end{array}$ & 300 TPD & stean & 1966 & & \\
\hline $\begin{array}{l}\text { Cuyahoga County, } \\
\text { Ohio/ }\end{array}$ & $\begin{array}{l}\text { waterral } 1 \\
\text { incineration }\end{array}$ & $1200 \mathrm{TPD}$ & stean, metal & 1979 & 33,000 & . \\
\hline 2. $\mathrm{RPF} \quad \therefore$ & & $\therefore$ & & & & \\
\hline $\begin{array}{l}\text { St. Louis, Mo.f } \\
\text { Union Elec. }\end{array}$ & RDF & $325 \mathrm{TPD}$ & $\begin{array}{l}\text { RDF, ferrous } \\
\text { motals, glass }\end{array}$ & $\begin{array}{l}\text { May } 72 \text { to } \\
1977\end{array}$ & $\begin{array}{r}2500 \\
-\end{array}$ & $\begin{array}{l}\text { closed duc to economic } \\
\text { and institutional } \\
\text { constraints }\end{array}$ \\
\hline Anes, Io./ & RDF & 200 TPD & $\begin{array}{l}\text { clectricity, } \\
\text { ferrous metal, } \\
\text { aluminum }\end{array}$ & Fal1 1975 & 5600 & \\
\hline Hempstead, N.Y./ & $\begin{array}{l}\text { RDF fired } \\
\text { waterwall }\end{array}$ & $750 \mathrm{TPD}$ & $\begin{array}{l}\text { stean, ferrous } \\
\text { metal, glass, } \\
\text { aluminum }\end{array}$ & Jan 1974 & 6000 & \\
\hline
\end{tabular}


Table $\mathrm{C}-1$ (continued)

\begin{tabular}{|c|c|c|c|c|c|c|}
\hline Location/Developer & Type & Capacity & Products & Start Up Date & $\begin{array}{l}\text { Capital Cost } \\
\left(10^{3} \$\right)\end{array}$ & Comment \\
\hline $\begin{array}{l}\text { Chicago (Crawford), } \\
\text { Ill. }\end{array}$ & RDF & $1000 \mathrm{TPD}$ & $\begin{array}{l}\text { RDF, ferrous } \\
\text { metils, glass }\end{array}$ & June 1976 & 17,500 & $\begin{array}{l}\text { RDF for use by local } \\
\text { utility }\end{array}$ \\
\hline $\begin{array}{l}\text { Milwaukee, Wi./ } \\
\text { American Can Co. }\end{array}$ & RDF & $1000 \mathrm{TPD}$ & $\begin{array}{l}\text { RDr, ferrous } \\
\text { metal, glass } \\
\text { aluminum }\end{array}$ & Nov. 1976 & 18,000 & $\therefore \quad \therefore$ \\
\hline $\begin{array}{l}\text { Bridgepnrt, Conn./ } \\
\text { Occidental Rescarch }\end{array}$ & RLF & $1800 \mathrm{TPD}$ & $\begin{array}{l}\text { Rnr, forrous } \\
\text { metal, glass } \\
\text { aluninum }\end{array}$ & $\begin{array}{l}\text { under constmic- } \\
\text { tion }\end{array}$ & $29,3 \cap 0$ & $\cdot$ \\
\hline Berlin, C.t./CRRA & RDF & 1400 TPD & $\begin{array}{l}\text { RDF, forrous } \\
\text { metal, glass } \\
\text { al:uninuni }\end{array}$ & $\begin{array}{l}\text { under construc- } \\
\quad \text { tion }\end{array}$ & 22,000 & 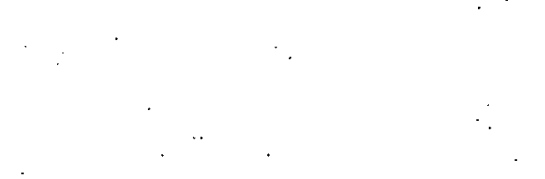 \\
\hline lilimington, Del./ & RDF & 500 Tाग & $\begin{array}{l}\text { RnT, forrous } \\
\text { metil, trlass }\end{array}$ & $\mathrm{N} \Lambda$ & 25,000 & . \\
\hline $\begin{array}{l}\text { Baltimore County, } \\
\text { Md.l. }\end{array}$ & RDF & $550 \mathrm{TPD}$ & $\begin{array}{l}\text { steam, ferrous } \\
\text { metal, glass }\end{array}$ & 1975 & & $\begin{array}{l}\text { steam for use in cement } \\
\text { plant }\end{array}$ \\
\hline Dade County, Fla./ & $\begin{array}{l}\text { wet pulp RDF } \\
\text { field waterwall } \\
\text { incinerator }\end{array}$ & 3000 TPD & $\begin{array}{l}\text { steam, ferrous } \\
\text { metal, glass } \\
\text { aluminum }\end{array}$ & NA & & $\begin{array}{l}\text { steam for use by local } \\
\text { utility }\end{array}$ \\
\hline Monroe County, N.Y./ & RDF & 2000 TPD & $\begin{array}{l}\text { RDF, ferrous } \\
\text { metal, glass } \\
\text { aluminum }\end{array}$ & NA & & $\begin{array}{l}\text { RDF for use by local } \\
\text { utility }\end{array}$ \\
\hline Bridgewater, Mass./ & $\mathrm{RDF}$ & 160 TPD & $\begin{array}{l}\text { RDF, ferrous } \\
\text { metal, glass } \\
\text { aluminum }\end{array}$ & 1974 & . & ECO-FUEL-11 plant \\
\hline N. Washington, D.C./ & RDF & 80TPD & $\begin{array}{l}\text { RDF, ferrous } \\
\text { metal, glass } \\
\text { aluminum }\end{array}$ & 1974 & & $\ldots$ \\
\hline
\end{tabular}


Table C-1 (continued)

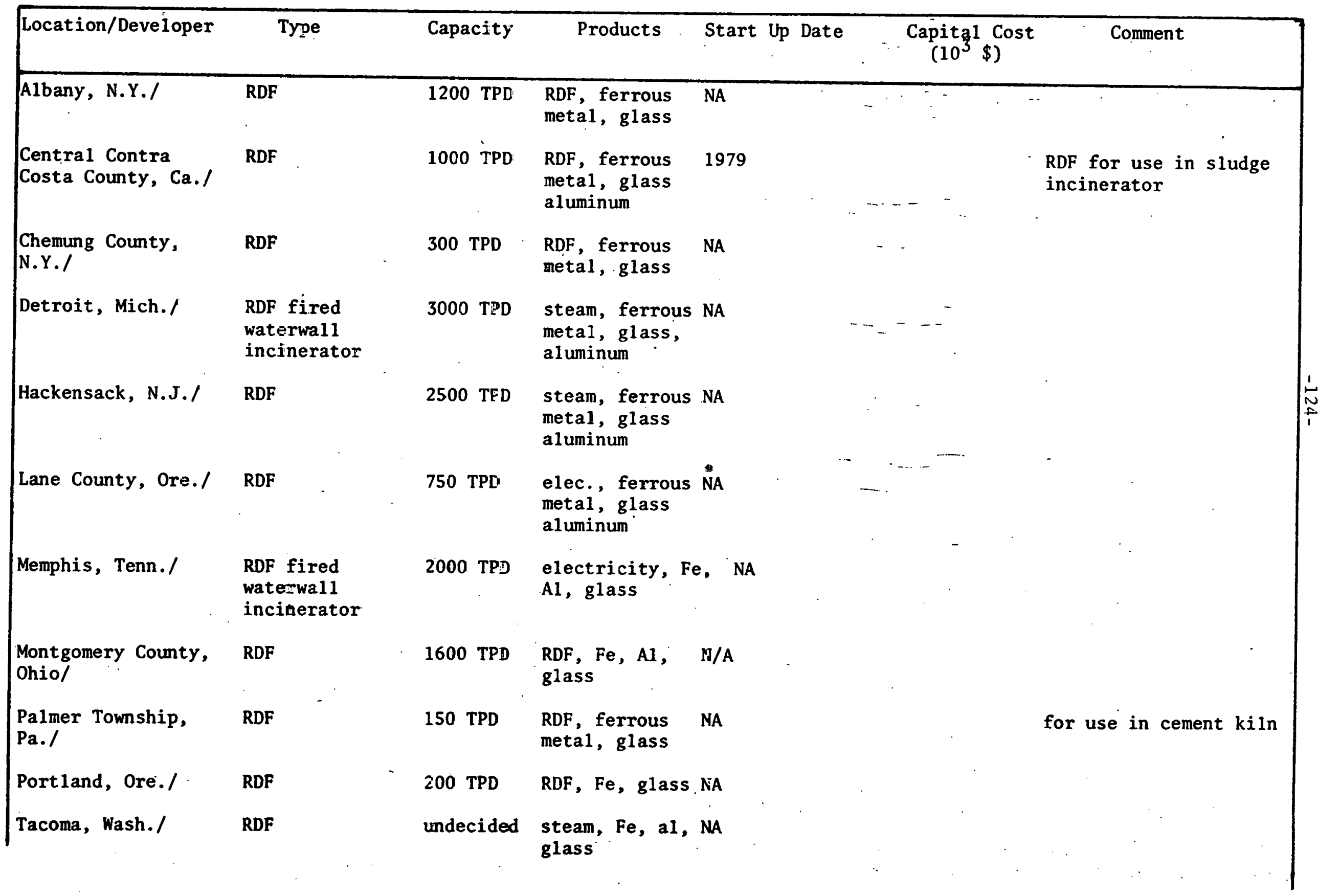


Table C-1 (continued)

\begin{tabular}{|c|c|c|c|c|c|c|}
\hline Location/Developer & Type & Capacity & Products & $t$ Up Date & $\begin{array}{l}\text { Capitąl Cost } \\
\left(10^{3} \$\right)\end{array}$ & Comment \\
\hline $\begin{array}{l}\text { New Britton, Conn.l } \\
\text { Eco-Fuel II }\end{array}$ & RDF & undecided & $\begin{array}{l}\text { electricity, } \\
\text { Fe, A1, glass }\end{array}$ & NA & $\cdot$ & \\
\hline $\begin{array}{l}\text { Los Gatos, Ca./ } \\
\text { Sira Corp. }\end{array}$ & RDF & $100 \mathrm{TPD}$ & $\begin{array}{l}\text { fuel pellets, } \\
\text { glass, ferrous } \\
\text { and non-ferrous } \\
\text { metals }\end{array}$ & 1976 & & $\begin{array}{l}\text { pilot plant undergoing } \\
\text { active testing }\end{array}$ \\
\hline Akron, Ohio/ & RDF & 1000 TPD & $\begin{array}{l}\text { steam, ferrous } \\
\text { and nonferrous } \\
\text { metal, glass }\end{array}$ & $\begin{array}{l}\text { start date } \\
\text { delayed }\end{array}$ & 25,400 & \\
\hline $\begin{array}{l}\text { Brockton, Mass./ } \\
\text { Eco-Fuel II }\end{array}$ & RDF & $400 \mathrm{TPD}$ & $\begin{array}{l}\text { RDF, ferrous and } \\
\text { nonferrous metals, } \\
\text { glass }\end{array}$ & 1973 & 12,000 & $\begin{array}{l}\text { expanded to } 400 \mathrm{TPD} \text { in } \\
1977\end{array}$ \\
\hline Madison, Wisc./ & RDF & $200 \mathrm{TPD}$ & $\begin{array}{l}\text { RDF, glass, paper, } \\
\text { ferrous and non- } \\
\text { ferrous metals }\end{array}$ & 1979 & & $\begin{array}{l}\text { RDF for use in utility } \\
\text { boilers }\end{array}$ \\
\hline $\begin{array}{l}\text { Montgomery County. } \\
\text { Md./ }\end{array}$ & RDF & 1200 TPD & $\begin{array}{l}\text { RDF, glass, } \\
\text { ferrous and non- } \\
\text { ferrous metals }\end{array}$ & $1979-1980$ & & \\
\hline New York, N.Y./ & RDF & 1500 TPD & $\begin{array}{l}\text { RDF, glass, ferrous } \\
\text { and non-ferrous met: }\end{array}$ & $a^{1980}$ & & \\
\hline Scranton, $\mathrm{Pa} . /$ & RDF & $500 \mathrm{TPD}$ & $\begin{array}{l}\text { steam, aluminum, } \\
\text { ferrous metals }\end{array}$ & 1980 & 16,000 & \\
\hline Toledo, Ohio/ & RDF & 1000 TPD & $\begin{array}{l}\text { ferrous metals, } \\
\text { RDF, glass }\end{array}$ & NA & & \\
\hline
\end{tabular}


Table $\mathrm{C}-1$ (continued)

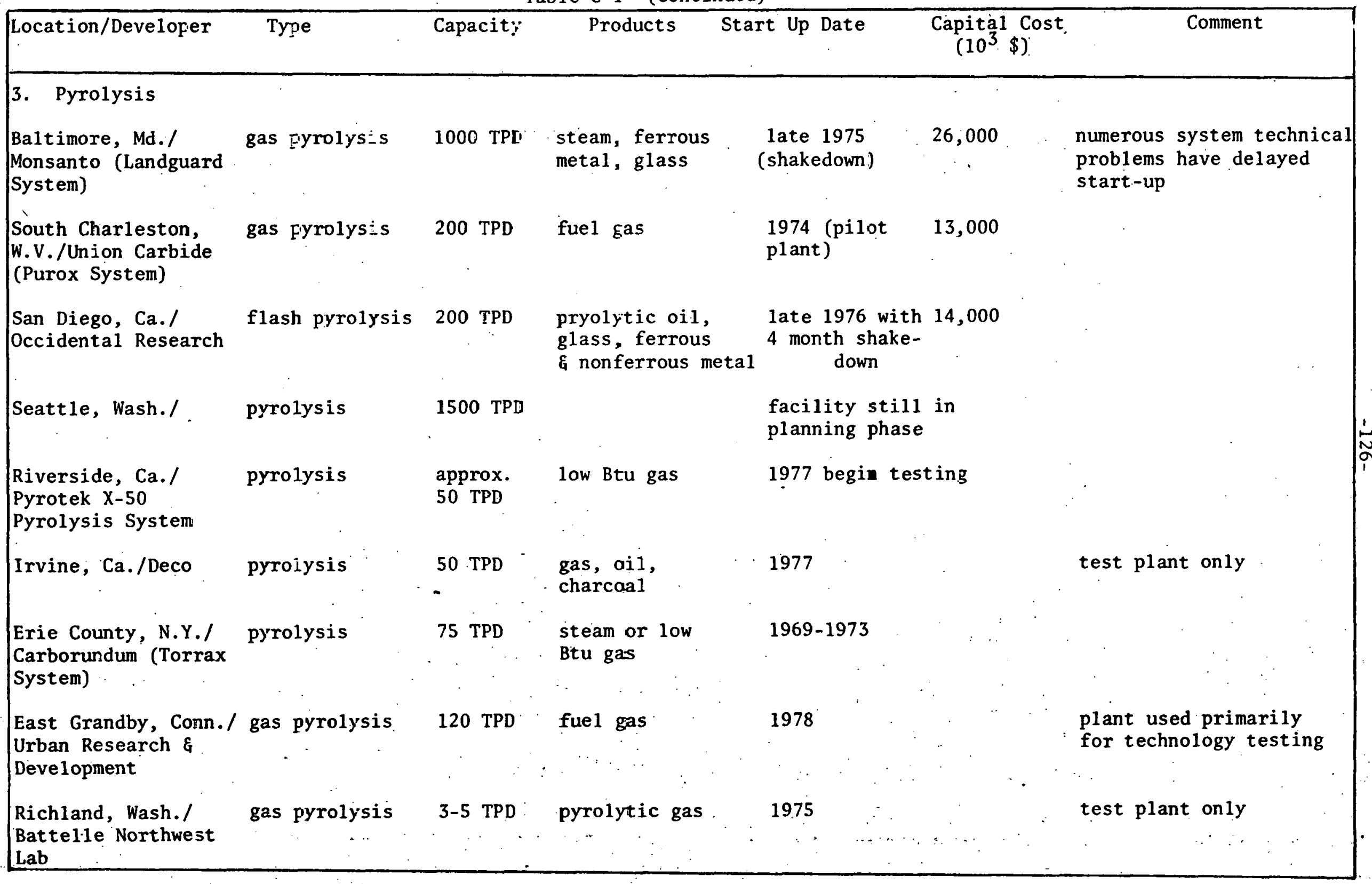


Table C-1 Footnotcs

1. Sources: Weinstein and Toro, 1976; levy, 1975; Hentworth, 1970; USEPA, 1976 and 1977; California State Solid Waste !lanagement Board, 1976 and 1977; Council on Environmental Quality, 1976 and 1977; McEwan and Levy, 1977.

2. Not Available. 
Table $\mathrm{C}-2$

U.S. Companies Currently Active in MSW Energy Recovery System Operation, Manufacturing, or Design 1

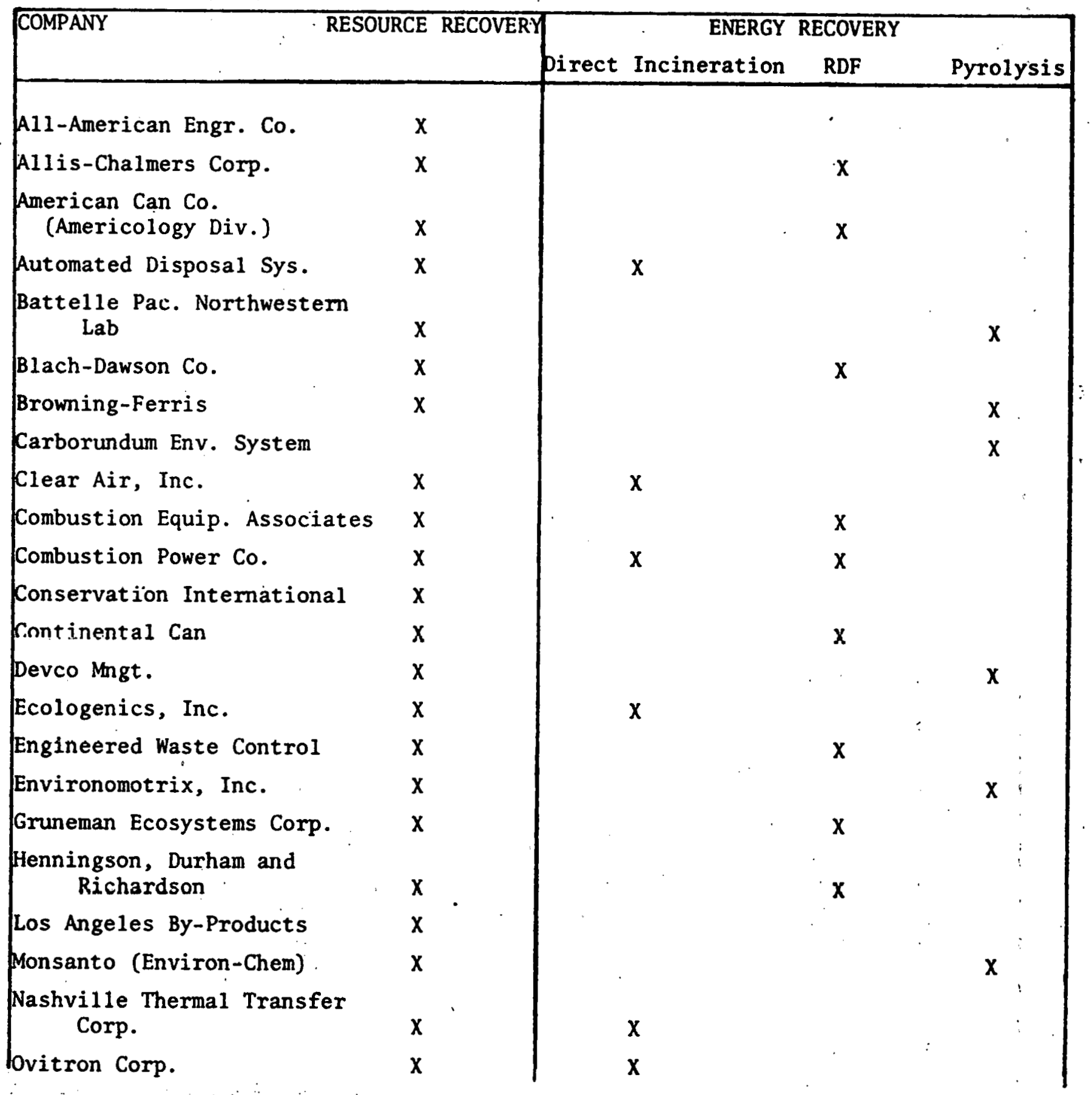


Table C-2 (continued)

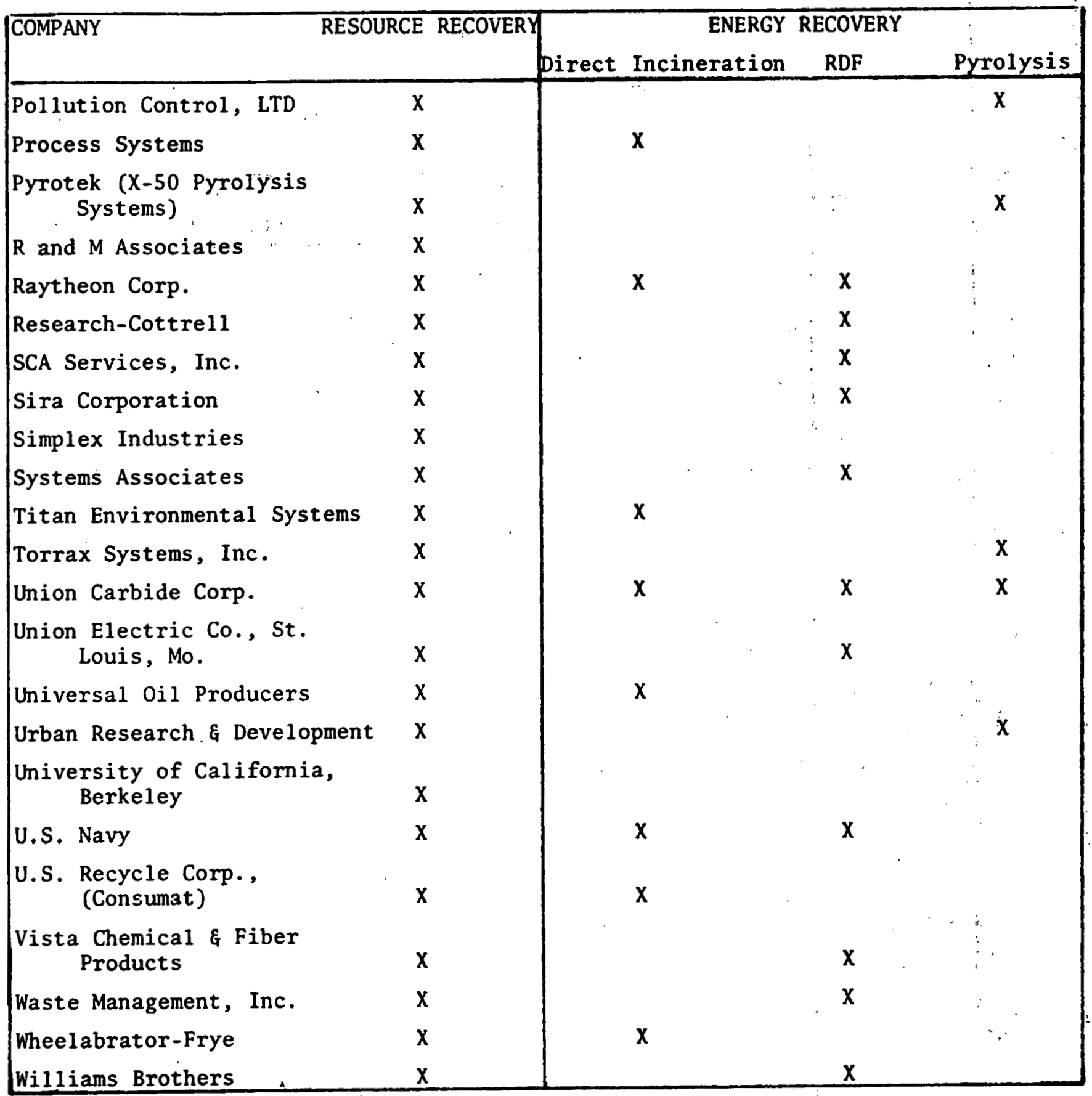

1. From: Wentworth, 1970; California State Solid Waste Management Board, 1975 and 1976; USEPA, 1977; Weinstein and Toro, 1976; Sheridan, 1976; U.S. Council on Environmental Quality, 1977 and 1978. 
Table C-3

Current Research Projects in MSW Energy Recovery ${ }^{1}$

Projects Funded by Department of Energy

Project Title

Study of Technical Problems of Nashville Incinerator

Environmental Control Requirements in Solid Waste Processing and Energy Reçovery Fasilities

Support of Equipment Test and Evaluation Facility (and Energy Conservation through Resource Recovery)

European Assessment

Co-firing in Cement Kiln

Tests of Gases from 200 TPD Pyrolysis Reactor

Pompano Beach: Advanced System Experimental Facility

Digester Mixing Tests .

H1gh Kate Anaerobic Digestion

Ut111zarion of Waste Carbon Monoxide as a Chemical Feedstock

Regional Study - Characterization and Waste Quantification

Amonia from Urban Wastes

Partial Home Heating and Cooling from Household Wastes
Contact/Performing Organization

R.B. Engdahl (ret.)

Battelle Columbus Laboratories

Ames Lahnratory

Iowa State University

Dr. Harvey Alter

National Center for Resource Recovery

H.C. Baille

Resource Planning Associates

Ron Jones

Environmental Equipment Corp.

W. Plant

Union Carbi-e, Linde Division

Peter Vardy

Waste Management, Inc.

J. Schwartbaugh

Systems Technology Corporation

C.D. Finney

Natura1 Dynamics

N.G. Wittenbrock

Battelle Pacific N.W. Laboratories

H.C. Baillc

Resource Planning Associates

Ms. C. Shreve

City of Seattle

R. Murray

General Electric Company

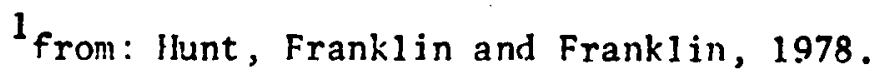


Table $\mathrm{C}-3$ (continued)

Project Title

Tnzynat ic livdroly'sis

$A_{1}$ i)lication of SGF:I Technology

Plug Flow Vs. Complex :Iix

Reactors for Iethane Formation

Biological Conversion of Organic

Refuse to :lethanc

Feedlot Fnergy Reclamation

Demonstration

Recovery of Fucl Gas from paste

Bench Scale Pesearch in the Thernochenical Conversion of Biomass

Construction of "rood "laste-to-nil

Facility

Technical Evaluation of

Raste-to-0il Plant

Heat Treatment of Organics for

Increasing Eiodegradability

Conversion of Biomass into Gaseous

Products

Experimental Prowran for the Albany, Oregon Waste-to-Oil Pilot Plant
Contact/Performing Orsanization

Jeo Snano

U.S. Arryy Laiborat orjes

Pollution Abatement Divisinn

i)r. :.J. liuf ?man

Texas Tech University

Dr. John T. Pfeffer

Iniversity of Illinois

Dr. Jolin T. Pfeffor

University of Illinois

Warren Coe

Ilamilton Standaril

Dr. Non lise

Dynatech

Paul Walku?

Battelle Pacific N. N. Laboratorics

R.J. LuII

'iarcon, Inc.

[nile 11. lioule

Bechtel Corporation

Dr. Perry :icCarty

Stanford Unjversity

Dr. Donald E. Farrett

Garrett Energy Research and Engincering

Dr. Sabri Frģun

Bechtel Cornoration 
Table C-3 (continued)

Project Title

Concepts for Improving the Fuel Quality of RDF

Preparation, Use and Cost of Densified RDF

Waste as a Supplementary Fue 1

Firing Densified RDF in a

Stoker Boiler

Utilization of Solid Waste as Fuel

St. Louis/Union Electric Supplementary Fuels Studies

Technical/Economic Assessments of Waste-as-Fuel Processes

Coincineration of MSW with Agricultural Wastes (Hawaii)

Preliminary Environmental Assessment of the Production and Use of Mothanol Fruin Non-Coal Sourcos

Ethanol Fuel Via Enzymatic Hydrolysis

Materials Recovery, RDF, Aluminum, Glass and Air Classification Research and Development

Preprncessing Systems

Evaluation

Acid Hydrolysis for Biological

Conversion

Environmental Effects of Utilizing

Solid Waste as a Supplementary

Power Plant Fuel',
Contact/Performing Organization

Dr. N. Norman Hecht

University of Dayton Research Institute

Dr. Harvey Alter

National Center for Resource Recovery, Inc.

Arnold Chantland

Public Works Director, City of Ames (Iowa)

Dx. Gregur Rigo

Systems Technology Corporation

Dale A. Vaughn

Battelle-Columbus Laboratories

Paul Gorman

Midwest Reserach Institute

E.M. Wi1son

Ralph M. Parson Co.

W.H. Hirai

County of Hawaii

W. Ballantyne

Battelle Columbus Laluratories

Leo G. Spano

U.S. Army Natick Laburatorles

Dr. Harvey Alter

National Centcr for Resuurce Recovery

David Bendersky

Midwest Research Institute

Dr. W. Brenner

New York Universit.y

Dale A. Vaughan

Battel1 Columbus Laboratories 
Table $\mathrm{C}-3$ (continued)

Project Title

Technical Assessment of Air Pollution Control at the Baltimore Demonstration Gas Pyrolysis Facility

Pilot Pyrolysis of Mixed Waste to Fuel

Preliminary Environmental Assessment of Biomass Conversion to Synthetic Fuels

Fine Grinding Technology

Assessment

Environmental Assessment of

Waste-to-Energy

Disposal of Sludge from Fluidized Bed Combustion Processes

Combustion and Emission Tests on Portable Pyrolysis Char and Oil

Glass Recovery Technology

Technical and Economic Analysis of Materials Recovery System New Orleans Recovery I

Technical Assessment Support Construction and Demolition Wastes Survey
Contact/Performing Organization

Tony E. Eggleston

TRW Systems Group, TRW, Inc.

Dr. Richard Stephens

Energy Resource Co., Inc.

S.T. DiNovo

Battelle Columbus Laboratories

M. Schrag

Midwest Research Institute

M. Schrag

Midwest Research Institute

Ralph Stone Company

ERDA-Pittsburgh Energy Research Center

Raytheon Company

J.F. Bernheisel

National Center for Resource Recovery

Systems Technology Corporation

J. Commins

JACA Associates 
Table $\mathrm{C}-3$ (continued)

\begin{tabular}{|c|c|c|c|}
\hline Projects Funded by other & Governmental Agencies & & \\
\hline Project Title & Contact/Performing Organizati & ion & \\
\hline $\begin{array}{l}\text { Anaerobic Conversion of Organic } \\
\text { Wastes into Methane by Thermo- } \\
\text { philic Bacterial Associations (USDA) }\end{array}$ & $\begin{array}{l}\text { J.G. Zeikus } \\
\text { University of Wisconsin }\end{array}$ & & . \\
\hline $\begin{array}{l}\text { Heat Treatment of Refuse for } \\
\text { Increasing Anaerobic Bio- } \\
\text { degradability (NSF) }\end{array}$ & $\begin{array}{l}\text { P.L. McCarty } \\
\text { Stanford University } \\
\end{array}$ & & \\
\hline $\begin{array}{l}\text { Biological Conversion of } \\
\text { Organic Refuse to Methane (NSF) }\end{array}$ & $\begin{array}{l}\text { Dr. J.T. Pfeffer } \\
\text { University of Illinols }\end{array}$ & & \\
\hline $\begin{array}{l}\text { Syngac frnm rnal fo Municipal } \\
\text { Solid Waste (NSF) }\end{array}$ & $\begin{array}{l}\text { Dr. H.W. Schulz } \\
\text { Columbia University }\end{array}$ & & \\
\hline $\begin{array}{l}\text { Preparation for Conversion } \\
\text { of Cellulose to Glucose (DoD) }\end{array}$ & $\begin{array}{l}\text { T.L: Reiling } \\
\text { Reiling Industries, Inc. }\end{array}$ & & \\
\hline $\begin{array}{l}\text { Secondary Resource Recovery } \\
\text { Programs (Including Pilot) } \\
\text { Plants (BoM) }\end{array}$ & $\begin{array}{l}\text { P.M. Sullivan } \\
\text { U.S. Department of Interior }\end{array}$ & & \\
\hline $\begin{array}{l}\text { Environmental Impact Evaluation } \\
\text { of Municipal Refuse as an Energy } \\
\text { Resource (BoM) }\end{array}$ & $\begin{array}{l}\text { Bureau of Mines } \\
\text { College Park Metallurgy Resear }\end{array}$ & $\operatorname{arch}$ & Center \\
\hline $\begin{array}{l}\text { Investigation on the Utilization } \\
\text { of Peanut Hulls in Feed and Non- } \\
\text { Feed Products (USDA) }\end{array}$ & $\begin{array}{l}\text { D. Burdick } \\
\text { Department of Agriculture }\end{array}$ & & \\
\hline $\begin{array}{l}\text { Technological Problems Inhibiting } \\
\text { the Increased Use of Recovered } \\
\text { Materials (NSF) }\end{array}$ & $\begin{array}{l}\text { Dr. Harvey Alter } \\
\text { National Center for Resource }\end{array}$ & Recc & overy \\
\hline $\begin{array}{l}\text { Methane Fermentation of Feedlot } \\
\text { Wastes (USDA) }\end{array}$ & $\begin{array}{l}\text { R.A. Rhodes } \\
\text { U.S.D.A. }\end{array}$ & & \\
\hline $\begin{array}{l}\text { Alternate Sources of Heat Energy } \\
\text { for Rural Maine (USDA) }\end{array}$ & $\begin{array}{l}\text { N. Smith } \\
\text { University of Maine }\end{array}$ & & . \\
\hline $\begin{array}{l}\text { Pyrolytic Conversion of } \\
\text { Cellulosic Materials (NSF) }\end{array}$ & $\begin{array}{l}\text { F. Shafizadeh } \\
\text { University of Montana }\end{array}$ & & \\
\hline $\begin{array}{l}\text { Pretreatment of Cellulosic } \\
\text { Materials to Increase the Rate } \\
\text { of Enzymatic Hydrolysis by } \\
\text { Partial Acid Hydrolysis (NSF) }\end{array}$ & $\begin{array}{l}\text { H.E. Grethlein } \\
\text { Dartmouth College }\end{array}$ & $\cdot$ & \\
\hline
\end{tabular}


Table $C-3$ (continued)

Project Title

Alternatives to the Conventional Use of Petroleum (DoD)

Uses of By-Product Polymeric Wastes Generated in Arkansas (DoT)
Contact/Performing Organization

J.M. Slaminski

U.S. Navy

W.V. Wyatt

Arkansas State University

*The letters in parenthesis indicate the funding agency. USDA = U.S. Department of Agriculture; NSF = National Science Foundation; DoD = Department of Defense; DoT $=$ Department of Transportation; BoM = U.S. Bureau of Mines 
Table $\mathrm{C}-3$ (continued)

Projects Funded by Non-Federal Public Organizations

Project Title

Energy Recovered from Processed Municipal Solid Waste (City of Los Angeles)

Fuel Gas Production from Municipal Solid Waste (University of Massachusetts)

Studies in Methanogenesis (Production of Methane, Sludge) Fertilizer and High Protein Feed for Agricultural Wastes (University of Hawaii)
Contact/Performing Organization

J.E. Bigger

Los Angeles City Department of Water

E.E. Lindsey

University of Massachusetts

R. Ross

University of Hawaii

*Funding agency is listed in parenthesis. 
Table C-3 (continued)

Projects Funded by Private Industry

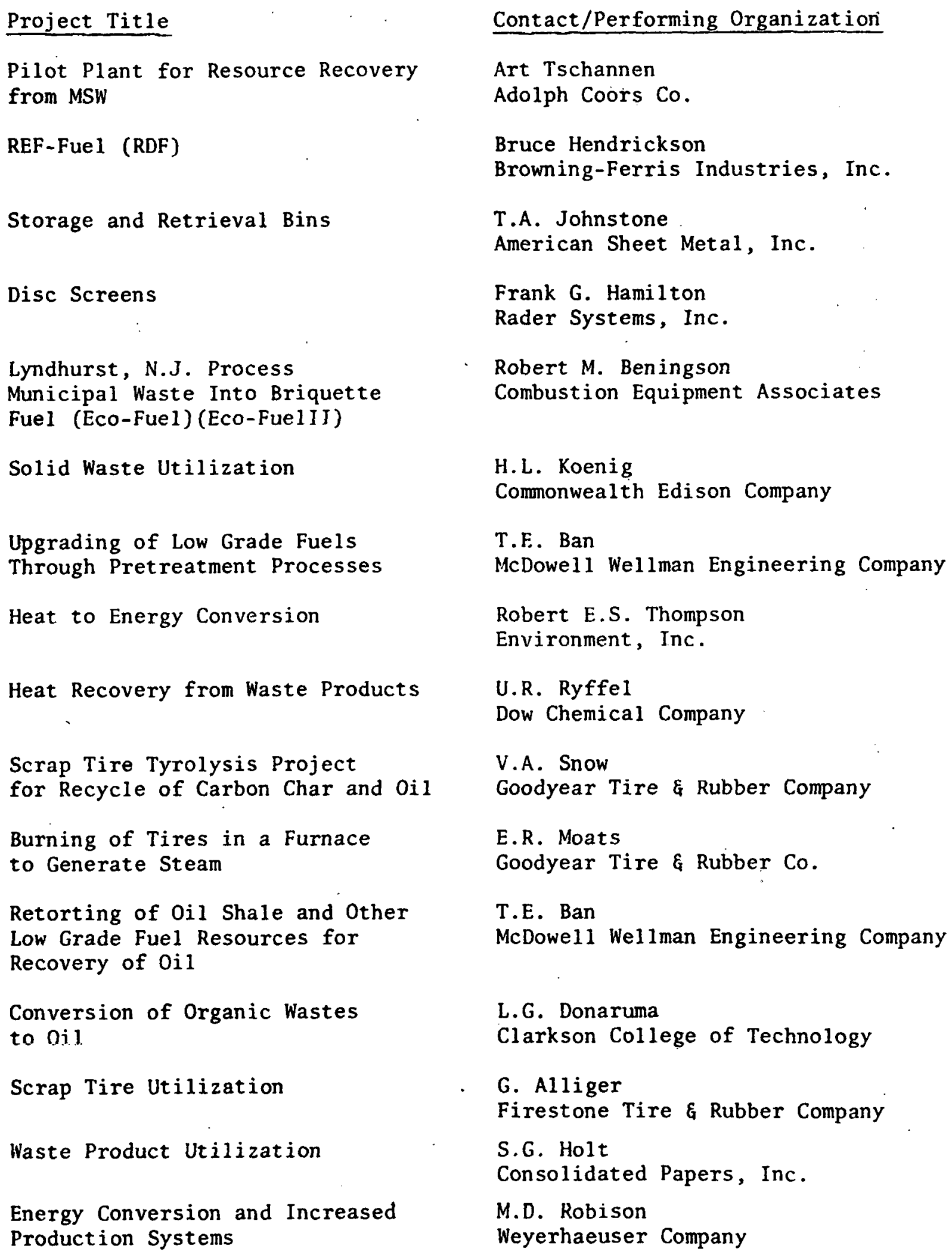

Project Title

Pilot Plant for Resource Recovery from MSW

REF-Fue1 (RDF)

Storage and Retrieval Bins

Disc Screens

Lyndhurst, N.J. Process

Municipal Waste Into Briquette

Fuel (Eco-Fuel) (Eco-Fue1II)

Solid Waste Utilization

Upgrading of Low Grade Fuels

Through Pretreatment Processes

Heat to Energy Conversion

Heat Recovery from Waste Products

Scrap Tire Tyrolysis Project

for Recycle of Carbon Char and Oil

Burning of Tires in a Furnace

to Generate Steam

Retorting of Oil Shale and Other

Low Grade Fuel Resources for

Recovery of $\mathrm{Oil}$

Conversion of Organic Wastes

to Dil.

Scrap Tire Utilization

Waste Product Utilization

Energy Conversion and Increased Production Systems

\section{Contact/Performing Organization}

Art Tschannen

Adolph Coors Co.

Bruce Hendrickson

Browning-Ferris Industries, Inc.

T.A. Johnstone

American Sheet Metal, Inc.

Frank G. Hamilton

Rader Systems, Inc.

Robert M. Beningson

Combustion Equipment Associates

H.L. Koenig

Commonwealth Edison Company

T.F. Ban

McDowell Wellman Engineering Company

Robert E.S. Thompson

Environment, Inc.

U.R. Ryffel

Dow Chemical Company

V.A. Snow

Goodyear Tire \& Rubber Company

E.R. Moats

Goodyear Tire \& Rubber Co.

T.E. Ban

McDowell Wellman Engineering Company

L.G. Donaruma

Clarkson College of Technology

G. Alliger

Firestone Tire \& Rubber Company

S.G. Holt

Consolidated Papers, Inc.

M.D. Robison

Weyerhaeuser Company 
Table $\mathrm{C}-4$

MSW Energy Recovery System Efficiency Comparison

\begin{tabular}{|c|c|c|c|c|c|c|c|c|c|c|c|c|c|c|c|}
\hline AETINOD & & IISiV & to $\mathrm{Fu}$ & $\begin{array}{l}\text { Per } \\
\text { Per }\end{array}$ & ent Ef & cier & SH: & $\begin{array}{l}\text { (Fner } \\
\text { Ste }\end{array}$ & eam & Recantil & MSit: t & to & Elect & tric & ity \\
\hline Estimate* & $\mathbf{a}$ & b & c & d & $\begin{array}{l}\text { Yean } \\
\text { Value }\end{array}$ & $\mathbf{a}$ & b & c & d & $\begin{array}{l}\text { Mean } \\
\text { Va lue }\end{array}$ & 21 & b & $c$ & d & $\begin{array}{l}\text { Pean } \\
\text { Valuc }\end{array}$ \\
\hline Naterwall & 100 & 100 & 100 & $10 n$ & 100 & & 58 & 67 & & 6.3 & & & 29 & & 29 \\
\hline Fluff RDF & 70 & 74 & : & 85 & 76.3 & 4.8 & 58 & & & 5.3 & 19 & & & 29 & 24 \\
\hline Dust RDF & & 80 & & & 80 & & 63 & & & 63 & & & & & \\
\hline liest RDF & & 76 & & & 76 & & 43 & & & $43^{\circ}$ & & & & & $\cdots$ \\
\hline Purox & & 6.1 & 64 & 66 & 64.7 & & 53 & & & 58 & & & & 22 & 22 \\
\hline Landguard & 75 & 78 & $\because$ & 66 & 74 & 42 & 42 & 54 & & 46 & $16 . .9$ & & & 22 & 19.4 \\
\hline Occidental & 26 & 26 & . & 46 & 32.7 & 23 & 23 & & & 23 & 0.2 & & & 16 & 12.6 \\
\hline Torrax & 34 & 65 & ; & & 74.5 & 58 & 37 & & & 47.5 & 23 & & & & .23 \\
\hline
\end{tabular}

"Efficiency $=\frac{\Sigma}{\Sigma \text { availiergy in }}$

** Estimate:

a. U.S. EPA 1976(b)

b. U.S. EPA 1977

c. Golueke and McGanhen, 1976

d. Oak Ridge National Laboratory, 1976 
REFERENCES: APPENDIX C

California State Solid Waste Management Board, Resource Recover: Pro:ran: Volume II Unabridged Report, 1976.

California State Solid Waste Management Board, Refuse to Energy Conversion Project, December 1977.

Council on Environmental Ruality, Enviornmental Mality--1976, The Seventh Annual Report to the President, 1976:

Council on Environmental Quality, Environmental Muality--1977, The Eighth Annual Report to the President, 1977. .

Golueke, C.G. and P. H. MCGanhey, "Waste Review", IN; Annual Review of. Energy, Volume 1, ERDA, 1976.

Oak Ridge National Labovatory, "Municipal Solid Waste Disposal," Net Energy Analysis of Five Energy Systems, Chapter 6, 1976.

Hunt, R. G., :1.A. Franklin and H.E. Franklin, "R\&D Resources Recovery Activities Report," Pesources Recovery and Conservation, 3, 1978.

Levy, S.J., San Diego County Demonstrator of Pyrolysis Solid Waste, prepared for the U.S. Environmental Prutectivin digeidcy, $157 j$.

McEwan, L. and S. Levy, "EPA Tracks Pronress of Facilities Implementins Resource Recovcry," Solid thastes lanagement, i.jarcii 1377.

Sheridan, J.H., "Garbage Power," Inclustry Week, Anril 19, 1970.

U.S. Environinental Protection Agency, Decision-Makers Guide in Solid Waste Management, Office of Solid Haste Rlanagement, Publication No. S!-500; 1976 .

U.S. Environmental Protection Agency, Fourth Report to Congress: Resource Recovery and Waste Reduction, Office of Solid Wastc Management, Publication No. Sil-600; 1977 .

Weinstein, N.J. and R. F. Toro, Thermal Processing of Municipal Solid Waste for Resource and Energy Recovery, Ann Arbor, MI: Ann Arbor Sciences Publisher, 1976.

Hentworth, $4 .$, Resource Recovery: Truth and Consequences, Washington, D.C.: Environmental Action Foundation, 1970. 
APPENDIX D

CURRENT STATUS OF COGENERATION SYSTEMS

A great variety of individual cogeneration systems is currently available on the open market. Three general types of cogeneration systems are characterized in this report; however, these systems by no means cover the entire spectrum of potential systems. Cogeneration systems are generally small-scale, are employed to support a single industrial activity rather than a general service system, and are tailored system by system to meet the specific product mix required by the industry.

Despite the flexibility and efficiency of cogeneration systems, their contribution toward national electrical energy production has declined from 15 percent in 1950 to four percent in 1970. The impediments to expanded use of cogeneration which have accounted for this decline are not technical, but rather economic and institutional. These impediments relate to the historical price of electricity, to institutional reluctance to enter into the fixed generation of two energy products, and to the inability of specific industries to profitably sell excess electricity into a utility grid. All of these variables are indirectly affected by the ratio of power output to heat output for a cogeneration system. This ratio determines how much excess electricity, if any, will be available to the utility grid. For example, a steam boiler and turbine system may produce $50 \mathrm{kWh} / 10^{6} \mathrm{Btu}$ of steam heat. A gas turbine-waste heat boiler, however, produces $200 \mathrm{kWh} / 10^{6}$ Btu of steam heat. Thus, while a gas turbine produces more electricity, it also produces less steam. The importance of this power/heat ratio is in matching the energy denand profile of an industry, especially where it is uneconomical to sell excess electric power.

As mentioned, the variety of cogeneration arrangements currently in use is large in order to match system supply characteristics and the demands of an industrial or commercial application. These systems have different fuel requirements and pollution emissions and can employ a variety of pollution control measures. Major system characteristics for some of the potential cogeneration combinations are shown in Table D-1.

The cogeneration systems described in Table D-1 are typical of industrial plant applications such as the diesel and fluidized bed systems described in this report. A second general application of cogeneration is for enhanced oil 
Table $D-1$

Cogeneration Systems

\begin{tabular}{|c|c|c|c|c|c|c|c|c|c|}
\hline Syster & $\begin{array}{c}\text { Size } \\
\text { (Hi elect.) }\end{array}$ & Fuel & $\begin{array}{l}\frac{\text { Elect }}{\text { Stean }} \\
\left(\mathrm{KH} / 10^{6} \cdot \text { BTU }\right)\end{array}$ & $\begin{array}{c}\text { FCP } \\
\text { (BTU/KWH) }\end{array}$ & $\begin{array}{l}\text { Prociess } \\
\text { steam } \\
\text { press } \\
\text { (psig) }\end{array}$ & $\begin{array}{c}\text { Total Plant } \\
\text { installed } \\
\text { cost } \\
(\$ / K W)\end{array}$ & Pollution & Controis & $\begin{array}{c}\text { General system } \\
\text { notes }\end{array}$ \\
\hline $\begin{array}{l}\text { Gas tumbire } \\
\& x \geq 5 \text { te heat } \\
\text { botier }\end{array}$ & $0.5+75$ & $\begin{array}{l}\text { - Gas } \\
\text { - } 2 \text { ofl } \\
\text { - Treated resid. } \\
\text { - SHG (low BTU) }\end{array}$ & 200 & 5,500 & $150-600$ & $\$ 350-400$ & $\mathrm{NO}_{x}$ & $\begin{array}{l}\text { - Hater or } \\
\text { steam } \\
\text { Injection }\end{array}$ & $\begin{array}{l}\text { - } 1000^{\circ} \mathrm{F} \text { exhaust } \\
\text { can be used as } \\
\text { clean hot gas }\end{array}$ \\
\hline $\begin{array}{l}\text { Diesel engine } \\
\text { \& baste heat } \\
\text { bolier }\end{array}$ & $0.5+25$ & $\begin{array}{l}\text { - Gas } \\
\text { - } 2 \text { ofl } \\
\text { - Treated resid. }\end{array}$ & 400 & 6,500 & $15-150$ & $\$ 350-500$ & $\begin{array}{l}\text { - Mox } \\
\text { - Part.'s }\end{array}$ & $\begin{array}{l}\text { - Tuning } \\
\text { - Steam Inject } \\
\text { - Baghouse }\end{array}$ & $\begin{array}{l}\text { - Efflclent at part } \\
\text { load and in stall } \\
\text { sizes } \\
\text { - High power/steaw } \\
\text { ratlo }\end{array}$ \\
\hline $\begin{array}{l}\text { Stean botier } \\
\text { \& turbine }\end{array}$ & $>1$ & $\begin{array}{l}\text { - Any oll } \\
\text { - Coal } \\
\text { - Has tes }\end{array}$ & $45-75$ & 5,000 & $15-600$ & $\$ 500-600$ & $\begin{array}{l}\mathrm{SO}_{2} \\
\mathrm{Part.}^{\prime} \text { 's } \\
\mathrm{NO}_{\mathrm{X}}\end{array}$ & $\begin{array}{l}\text { - Low S fuel. } \\
\text { scrubber } \\
\text { - Preclpitaror } \\
\text { - Design }\end{array}$ & $\begin{array}{l}\text { - Effletent at } \\
\text { part lodd }\end{array}$ \\
\hline $\begin{array}{l}\text { Cottlred eycle } \\
\text { a waste heat } \\
\text { boller }\end{array}$ & $1+150$ & $\begin{array}{l}\text { - Gas } \\
\text { - :2 oll } \\
\text { - SNG }\end{array}$ & 150 & 5,000 & $15-900$ & $\$ 350-450$ & $\mathrm{NO}_{x}$ & $\begin{array}{l}\text { - Hater or steam } \\
\text { Injection }\end{array}$ & $\begin{array}{l}\text { - Varlable power/ } \\
\text { stean ratio } \\
\text { - Back pressure } \\
\text { stean turbine }\end{array}$ \\
\hline $\begin{array}{l}\text { Steas } \\
\text { bottoning. }\end{array}$ & $0.5 \bullet 10$ & - Haste heat & M.A. & 0 & N.A. . & $\$ 400-600$ & N.A. & K.A. & $\begin{array}{l}\text { - Effictent at } \\
\text { part lodd } \\
\text { - Uses exhaust } \\
\text { >900. }\end{array}$ \\
\hline $\begin{array}{l}\text { Crgente } \\
\text { bot:ouing }\end{array}$ & $0.6-1$ & - Haste heat & N.A. & 0 & N.A. & $\$ 400-700$ & M.A. & N.A. & $\begin{array}{l}\text { - Efflctent at } \\
\text { part load } \\
\text { - Uses exhaust } \\
\text { o0o f } \\
\text { - Prototyces avall. } \\
\text { - Requlres cooling } \\
\text { Nater }\end{array}$ \\
\hline
\end{tabular}


recovery. As an example of this type of system, Pacific Gas and Electric Company. is negotiating with Getty and Texaco to install combustion turbine cogeneration systems of 280 and 270 MWe capacity, respectively, in Kern County, California oil fields. The oil companies have been blocked from further development of steam injection because of $\mathrm{SO}_{2}$ and $\mathrm{NO}_{x}$ emissions constraints from crude oil. boilers. The economic situation discourages cleanup by the oil companies so they approached PGEE with the offer of inexpensive oil in exchange for steam. Electricity generation in turn allows PG\&E to invest in oil gasification and desulfurization equipment to meet emission constraints. This institutional arrangement provides energy, economic and environmental advantages and although no cogeneration systems have been installed at present, there is a significant potential for their installation in the future. As stated above PG\&्ष is presently negotiating for 490 MWe of baseload capacity, supplying $3.6 \times 10^{6}$ $\mathrm{lbs} / \mathrm{hr}$ steam. This steam capacity is only one-fifth of the present steam generation in the three major Kern County oil fields (Kern River, Midway-Sunset, and S. Belridge). Additionally, there are several other significant heavy oil deposits in California as listed in Table D-2.

The recoverable heavy oil figures given in Table $D-2$ are conservative with respect to cogeneration potential because they consider only 1975 technologies and economics. This would be steam soak methods of recovering $\$ 5.25 / \mathrm{bbl}$ oil. Doubling the value of the oil will permit steam drive methods and increase the recoverable reserves by 30-50 percent. On the other hand, two-thirds of this oil will be recovered using steam while ore-third will be recovered with $\mathrm{CO}_{2}$ flooding or detergent drives which do not use cogeneration. Finaliy, the list only considers the largest fields capable of supporting a 200 MWe cogeneration plant for at least 15 years.

While enhanced oil recovery supports the petroleum drilling operation exclusively, fluidized-bed and diesel cogeneration are particulariy attractive to several major industrial sectors. Table D-3 lists projections reported for cogeneration activity in 1985 for six major industries which require both electricity and process heat within the temperature and oressure ranges for which cogeneration is an efficient producer. 
Table D-2

Potential for Expanded Enhanced Oil Recovery in California

\begin{tabular}{|c|c|c|c|c|c|}
\hline Field & County & $\begin{array}{c}\text { API } \\
\text { Gravity }\end{array}$ & $\begin{array}{c}\text { Oil-in- } \\
\text { Place } \\
10^{9} \text { bb1 }\end{array}$ & $\begin{array}{c}\text { Recoverable } \\
1^{1975} \\
10^{9} \text { bbl }\end{array}$ & Project Sponsor \\
\hline Cat Canyon & Santa Barbara & $o_{11-13}$ & 7.3 & 1.4 & ERDA-Getty oil \\
\hline Santa Maria Valley & Santa. Barbara & ${ }^{o_{14}}$ & 5.1 & 1.0 & Union Oil \\
\hline Kern River & Kern & ${ }^{0}{ }_{13}$ & 3.3 & 0.6 & Getty-Standard \\
\hline Midway-Sunset & Kern & $0_{11}$ & 2.5 & 0.5 & ERDA-Chanslor Oil \\
\hline Kern Front & Kern & ${ }^{0} 14$ & 1.3 & 0.3 & Several small projects \\
\hline Cymric & Kern & ${ }^{0} 12-14$ & 1.2 & 0.2 & Several small projects \\
\hline San Ardo & Monterey & ${ }^{o_{11}}$ & 1.2 & 0.2 & Texaco and Mobil \\
\hline Poso Creek (Premier) & Kern & $o_{12-13}$ & 1.0 & 0.2 & None \\
\hline Casmalia & Santa Barbara & ${ }^{\circ} 10$ & 0.9 & $0-0.2$ & None \\
\hline Dxnard & Ventura & $07-8$ & 0.9 & 0 & None \\
\hline Mckittrick & Kerin & ${ }^{0} 14-15$ & 0.9 & 0.2 & Getty $0 i 1$ and others \\
\hline Suadalupe & San Luis Obispo & ${ }^{0} 11$ & 0.1 & 0.02 & None \\
\hline Paris Valley & Monterey & ${ }^{0} 11$ & 0.06 & 0.01 & ERDA-Husky Oil \\
\hline
\end{tabular}

${ }^{0} 15-10$ (API): $19 \%$ recovery factor; ${ }^{0} 10-7: 0 \%$ recovery factor

Sources: Estimates by Alan Leighton, ERDA-SAN, September 1, 1976; A. Leighton and J. Patek, Combination Thermal Drive to Recovery Very Heavy Oil from Paris Valley Field, California, 2nd Annual ERDA Symposium on Enhanced Oil Recovery, Tulsa, Oklahoma (Sept. 1976). 
Table D-3

Cogeneration Projections for 1985

\begin{tabular}{lc}
\hline \multicolumn{1}{c}{ Industry } & $\begin{array}{c}1985 \text { Cogeneration } \\
\text { Capacity, }{ }^{*} \text { MN }\end{array}$ \\
\hline Food & 343 \\
Textiles & 98 \\
Pulp and paper & 4,861 \\
Chemical & 2,677 \\
Petroleum refining & 763 \\
Steel & 1,423 \\
TOTAL & 10,165 \\
\hline
\end{tabular}

Assuming no government action 


\section{APPENDIX E \\ APPLICATIONS OF COGENERATION SYSTEMS}

This appendix describes in some detail two potential applications of cogeneration: fluidized bed combustion in the pulp and paper industry and enhanced oil recovery.

COGENERATION IN THE PULP AND PAPER INDUSTRY: A BRIEF OVERVIEW Industry Description

The pulp and paper industry in the U.S. consists of over 350 companies together representing over 700 operating mills. The output of this sector totaled about 600 pounds of paper and cardboard products per person in 1975 . Total industry capacity is about 200,000 tons per day, almost half of which is located in the southeastern United States (Table E-1). Integrated mills with both pulping and forming facilities account for about 70 percent of industry capacity. These mills have an average annual capacity of about 300,000 tons. Non-integrated mills (forming facilities only) tend to be smaller, with only about 15,000-20,000 tons annual capacity on the average. Industrial plants are thus large and capital-intensive; a new installation can exceed $\$ 300$ million.

\section{Fuel Consumption}

Some 90 percent of the fuels consumed in the industry are used to produce process steam at temperatures between $250-390^{\circ} \mathrm{F}$, and between 50 and 175 psig. The industry generates a tremendous amount of biomass fuel in the form of bar, wood chips and spent liquor (the waste product from the pulping process). In terms of Btu potential such wastes accounted for 44 percent of all energy consumption in the industry nationwide (Thermo Electron Corporation, 1976, Table 4.27)*

Fuel and Energy Uses

While most of the steam is used at relatively low temperatures and pressures, much of it is produced at higher pressures, allowing ample application of steam turbine topping cycle electrical generation. In fact, the

*Thermo Electron Corp, A study of Inplant Flectric Power Generation in the Chemical, Petrol eum Refining and Pulp and Paper Industries. Ioodham, Msec. NTIS, PB255-659, June 1976. 
Table E-1

Region Distribution of the

Pulp and Paper Industry

\begin{tabular}{|c|c|c|c|c|}
\hline Region & States & Mills (\%) & Capacity & $(\%)$ \\
\hline New England & $\begin{array}{l}\text { Maine, New Hampshire, } \\
\text { Vermont, Rhode Island, } \\
\text { Massachusetts, } \\
\text { Connecticut }\end{array}$ & 15 & 8 & \\
\hline $\begin{array}{l}\text { Middle } \\
\text { Atlantic }\end{array}$ & $\begin{array}{l}\text { New York, New Jersey, } \\
\text { Pennsylvania. }\end{array}$ & 18 & 10 & \\
\hline $\begin{array}{l}\text { East North } \\
\text { Central }\end{array}$ & $\begin{array}{l}\text { Ohio, Indiana, Illinois, } \\
\text { Michigan, Wisconsin }\end{array}$ & 22 & 16 & \\
\hline $\begin{array}{l}\text { West North } \\
\text { Central }\end{array}$ & $\begin{array}{l}\text { Minnesota, Iowa, } \\
\text { Montana, North } \\
\text { Dakota, South Dakota, } \\
\text { Nebraska, Kansas }\end{array}$ & 4 & 3 & \\
\hline South Atlantic & $\begin{array}{l}\text { Delaware, Maryland, } \\
\text { Washington, D.C. } \\
\text { Virginia, West Virginia, } \\
\text { North Carolina, South } \\
\text { Carolina, Georgia, } \\
\text { Florida }\end{array}$ & 12 & 24 & \\
\hline $\begin{array}{l}\text { East South } \\
\text { Central }\end{array}$ & $\begin{array}{l}\text { Kentucky, Tennessee, } \\
\text { Alabama, Mississippi }\end{array}$ & 7 & 12 & \\
\hline $\begin{array}{l}\text { West South } \\
\text { Central }\end{array}$ & $\begin{array}{l}\text { Arkansas, Louisiana, } \\
\text { Oklahoma, Texas }\end{array}$ & 8 & 12 & \\
\hline West & $\begin{array}{l}\text { Montana, Indiana, } \\
\text { Wyoming, Colorado, New } \\
\text { Mexico, Arizona, Utah, } \\
\text { Nevada, Washington, } \\
\text { Oregon, California, } \\
\text { Hawaii, Alaska }\end{array}$ & 14 & 15 & \\
\hline
\end{tabular}


industry consumption of electrical power per ton of product has grown significantly over the years, and the use of higher boiler pressures has followed this trend. During the 1965-1975 period, the largest boiler capacity additions were in the 850-1250 psig range, and significant capacity was added at pressures greater than 1250 psig (Thermo Electron Corporation, 1976, Table 4.40).

Natural gas is used for direct fire hot air dryers and space heating, as well as for some boiling. Residual oil is also used directly in lime kilns to fire the pulping chemical recovery process. Thus residual oil use is roughly proportional to energy generated from liquor. The lime kiln operations require about. $2 \times 10^{6} \mathrm{Btu}$ of oil per ton of paper. Energy generated in spent liquor is about $20 \times 10^{6}$ Btu per ton of paper product. It should be borne in mind, however, that boiler/recovery efficiencies are not the same for the biomass fuels and for the purchased fossil fuels. The American Paper Institute (API) estimates an average boiler efficiency of 85 percent from purchased fuels (e.g. $15 \%$ stack loss), 70 percent from bark, and 60 percent for spent 1 iquor.

\section{Thermodynamic Potential for Increased Cogeneration}

The potential for bottoming of wasteheat in the pulp and paper industry is believed to be negligible. The waste heat from stack gases, warm water, heated air, and water vapor ranges from $100^{\circ} \mathrm{F}$ to $400^{\circ} \mathrm{F}$, too low to result in any substantial electrical generation. The remainder of this section will therefore deal with topping potential.

For topping cycles, the maximum potential electrical generation depends on the industry's steam flow requirements (amount of steam per unit time and its pressure and temperature), and the type of topping cycle. In 1975 for the industry as a whole, the amount of steam used was about $1100 \times 10^{12} \mathrm{Btu}$, averaging about $1.421 \times 10^{8}$ bs per hour, most of which is at 50-400 psig, The standard power to steam ratios for steam turbine, gas turbine, and diesel topping cogeneration are about $45 \mathrm{kWh} / 10^{6} \mathrm{Btu}, 200 \mathrm{kWh} / 10^{6} \mathrm{Btu}$, and $400 \mathrm{kWh} / 10^{6}$ Btu, respectively. Applying figures such as these to the total process steam requirements yields the maximum electrical generation potentials (Table E-2).

We note that even under steam turbine topping, the maximum generation exceeds current implant generation, suggesting substantial increases even at present levels of economic activity and extensive implant generation. 
Table E-2

Maximum Potential for Inplant Generation of Electricity in $\mathrm{klVh} /$ Year in the Pulp and Paper Industry

\begin{tabular}{|c|c|c|c|c|c|c|c|}
\hline \multirow{3}{*}{ Region } & \multicolumn{7}{|c|}{ Electrici‡y $\left(10^{9} \mathrm{kWh} /\right.$ year $)$} \\
\hline & \multicolumn{3}{|c|}{ Maximun Potential Generation ${ }^{1}$} & \multirow{2}{*}{$\begin{array}{l}\text { Total } \\
\text { Used } 2\end{array}$} & \multirow{2}{*}{$\begin{array}{l}\text { Maximum } \\
\text { Steam } \\
\text { Turbine } \\
\text { Topping }\end{array}$} & Potential & \multirow{2}{*}{$\begin{array}{c}\text { Export }^{3} \\
\text { Diese1 } \\
\text { Topping }\end{array}$} \\
\hline & $\begin{array}{l}\text { Steam } \\
\text { Turbine } \\
\text { Topping }\end{array}$ & $\begin{array}{l}\text { Gas } \\
\text { Turbine } \\
\text { Topping }\end{array}$ & $\begin{array}{l}\text { Jiesel } \\
\text { Topping }\end{array}$ & & & $\begin{array}{l}\text { Cas } \\
\text { Turbine } \\
\text { Topping }\end{array}$ & \\
\hline New England & 4.4 & 15 & 30 & 4.2 & 0.2 & 10.8 & 25.8 \\
\hline Mid-Atlantic & 3.4 & 12 & 23 & 3.6 & $(0.2)^{64}$ & 8.4 & 19.4 \\
\hline East North Central & 7.4 & 26 & 52 & 7.4 & -- & 18.6 & 44.6 \\
\hline West North Central & 1.0 & 3.6 & 7.1 & 1.2 & $(0.2)$ & 2.4 & 5.9 \\
\hline South Atlantic & 18 & 65 & 130 & 14 & 4.0 & 51 & 116 \\
\hline East South Central & 8.5 & 30 & 59 & 7.2 & 1.3 & 22.8 & 51.8 \\
\hline West South Central & 9.1 & 32 & 64 & 8.6 & 0.5 & 23.4 & 55.4 \\
\hline Mountain \& Pacific & 9.7 & 33 & 67 & 10 & $(0.3)$ & 23 & 57 \\
\hline TOTALS & 61.5 & 216.6 & 432.1 & .56 .2 & 5.3 & 160.4 & 375.9 \\
\hline
\end{tabular}

\section{Notes}

1. Maximum potential zeneration - topping process steam (the opportunities for topping of process heat and bottoming of waste heat in the puip and paper industry are minimal).

2. Purchased plus inplant generation (hydro not included).

3. Maximum potential for export - maximum potential generation minus purchased electrical minus inplant generated electricity.

4. Use greater than maximum potential. 
Gas turbine and diesel topping could generate substantial exports of electricity. Several caveats must be mentioned, however. First, gas turbines and diesel systems require more total fuel to generate any given usuable electricity-plussteam Btu equivalent, due to higher efficiency of the steam turbine. There is more unrecoverable heat output in these systems than in steam turbine systems. Second, the pulp and paper industry requires tremendous amounts of steam, as noted above. Finally, gas and diesel systems require petroleum. fuel inputs. Steam generation allows the burning of coal and other solid biomass fuels. This is an important factor for the pulp and paper industry whose waste already comprises between 40 and 50 percent of its fuel inputs.

\section{Economic Potential for Increased Cogeneration}

The implementation of cogenerated electricity and steam systems on a wide scale requires additional investment in instances where these products are generated separately. That such investment has been forthcoming only in small amounts in the U.S. is not surprising when historical realities are considered. Low energy. costs and rapid postwar expansion of centralized, utility-run power systems, coupled with an emphasis by industry on first costs have selected against cogeneration, as witnessed by the decline in cogenerated electricity as a percent of total generation in the U.S. since 1950. The enormous increases in petroleum fuel costs and the steady growth of industrial plant size have begun to turn cogeneration's economic picture. around. In general, the measure utilized to determine the viability of an investment is the level of internal rate of return. Essentialiy, "the internal rate of return $(r)$ is determined for any given investment by the following formula

$$
c=\sum_{i=1}^{N} \frac{R_{i}}{(1+r)} i
$$

where

$$
\begin{aligned}
& c=\text { capital costs } \\
& R_{i}=\text { after-tax returns in year } i \\
& N=\text { expected lifetime of investment in years } \\
& r=\text { internal rate of return. }
\end{aligned}
$$


The rate of return required by a business to justify investment depends many factors, particularly the degree of expected market risk, borrowing costs, and debt/equity ratios. It has been estimated that for the pulp and paper industry, the average rate of return required over all investments is about 15 percent after tax. In general, industries need a higher rate of return for cost saving investments such as cogeneration than for product oriented investments which are associated with direct profitability, market expansion, and the like. On the other hand, a lower rate is required by utilities (around 13\%) because electricity (and steam in some cases) is the utility's primary product. Moreover, as a regulated industry, utilities can usually borrow at lower rates. Thus implementation could depend on generation plant ownership. In fact, the pulp and paper industry generates 55-60 percent of its own electricity in-plant, making it likely that it might invest in cogeneration at return rates fairly close to its industry average.

Another issue facing cogeneration implementation is whether or not it is associated with expansion or replacement of process steam facilities. If cogeneration is considered as industry expands or replaces worn out or obsolete boilers, pipes, pumps, fans, etc., then initial investment capital costs estimates are reduced because the firm will only consider the incremental costs associated with electricity generation (e.g. costs of turbine, generator, etc.). If existing and useful process steam equipment must be replaced, however, the total costs of the new system must be used, including those associated with steam production.

A final consideration influencing rate of return are tax policy and financing options. Both increased investment tax credit (such as are proposed in President Carter's national energy policy) as well as decreased corporate income tax rate would increase expected rates of return. Also, if a company has access to outside capital at interest rates below the expected return rate, its willingness to invest can be expected to increase relative to a base case situation in which it had to generate all its funds internally or dilute its equity.

The Effect of Economic Incentives on Potential Implementation by 1985

To assess the potential for increased cogeneration, one must make assumptions regarding industrial growth. The estimates shown below are 
based on the following projections: (a) the amount of steam and electricity would increase by 50 percent in the 1975-85 period, implying a conservative 3.2 percent real annual growth rate, and (b) 75 percent of existing (1975) capacity. is assumed to be still in place by 1985. The economic incentives considered are increased tax credits (up to 50 percent of new investment in cogeneration), lower corporate tax rates (down to $25 \%$ of income) and the availability of up to 50 percent financing at 10 percent.

With steam topping, only very small amounts of electricity will have to be purchased by 1985. Even in the base, case of no added incentives (e.g. current tax structures and no debt financing) and industry ownership of facilities, self-generation would amount to about 65 percent of industry needs. With incentives for industry or under a system of utility ownership, cogeneration could account for 82-99 percent of industry's power needs. With gas turbines and diesel cogeneration, given appropriate petroleum, synthetic fuels or adequate fluidized bed combustion technology, substantial electricity could be exported: from a low of 2.2 percent (given gas turbine topping, industry ownership, and no incentives) to a high of 9.6 percent. The latter case assumes diesel topping, utility olmership, all tax incentives, and outside financing options.

Potential fuels savings for 1985 would be about 70,000 bbl of oil per day for the steam systems and $290,000 \mathrm{bbl} /$ day for both gas turbine and diesel topping (Thermo Electrnn Corporation, 1976, Table 6.31). These estimates assume industry ownership and all economic incentives. For utility ownership, assuming all incentives, the savings are 110,000-135,000 bb1/day, 380,000$420,000 \mathrm{bbl} / \mathrm{day}$, and 480,000-580,000 bbl/day for steam, gas and diesel topping, respectively. The increase in savings listed here for gas and diesel wuld need to be modified somewhat if their higher heat rate were taken into account.

Fluidized Bed System for the Pulp and Paper Industry

Fluidized bed cogeneration system is suggested for use in the pulp and paper industry because of its ability to burn both coal and waste fuels efficiently and cleanly.

Two significant trends in the energy field today are fuel switching from oil and gas to coal and waste fuels and also decreasing environmental impact. The combination of these trends is largely contradictory on the basis of existing experience with coal combustion. This, however, should change in 
the near future with the implementation of fluidized bed combustion (FBC) which inherently produces low emissions. Furthermore, it is of small to moderate size scale which makes it well suited to use in cogeneration applications. Cogeneration complements FBC well by maximizing efficiency in the use of waste and fossil fuels to produce both electricity and process heat for use by industry. Unfortunately industries tend to be located where ambient air quality is already poor and where emissions impact on large populations. Thus fluidized bed combustion is expected to be significant in the future and its emissions and their control will be especially important.

The first feature of $\mathrm{FBC}$ is the fact that it allows any type of coal or waste fuel to be burned regardless of ash content or caking properties. Furthermorc, the coal requires little processing such as washing and pulverization as done in modern coal plants because the ash is easily included in the bed material. Generally the coal is only crushed to $1 / 4$ inch size to ease fuel feeding.

The ability to burn any coal or waste material and to burn it cleanly is a feature because of coal's variability. Coal varies in its physical properties and chemical composition. Some coals produce too much ash. or slagging ash and so cannot be used in some boilers. This does not interfere with FBC, however, because of the small fraction of coal in the fluidizcd bed. Likewise, sulfur content can vary from 0.5 percent to 5 percent by weight. Once again, the large bed or sorbent can easily adapt to varying sulfur removal rates by adjusting flow rates. This is an advantage under proposed New Source Performance Standards which require go percent control regardless of sulfur in the fuel rather than simply meeting an emission standard with some combination of low sulfur coal plus a scrubber. Thus an industry with 90 percent sulfur control in FBC will have flexibility in choosing coal supplies. This is particularly important for small industrial users which tend to have greater variability in their coal supplies because they cannot claim an entire mine's production as a utility power plant does.

\section{Combustion}

The most important features of combustion for power generation and process heat are combustion temperature, heat transfer and overall efficiency. 
In general higher temperatures mean greater efficiency in energy conversion to electricity. "The limiting factor, however, is not combustion but rather a problem with materials. For example, high pressure steam pipes can only withstand $566^{\circ} \mathrm{C}$. Most gas turbine blades are damaged bv temeratures nver $950^{\circ} \mathrm{C}$. Thus, we do not have the technology to take advantage of the thermodynamjc potential of coal combustion flames at $2000^{\circ} \mathrm{C}$. To limit temperatures, boilers maintain a large excess air flow to dilute the combustion gases. Fluidized bed burners must also maintain a large working fluid flow to limit temperatures but do so in the combustion zone so that actual combustion temperatures can also be reduced to about 800 or $900^{\circ} \mathrm{C}$ or less. The bottom limit would be the ignition temperature of 500 to $600^{\circ} \mathrm{C}$ depending on the fuel.

\section{Fluidized Bed Combustors}

The characteristics of fluidized bed combustion are determined by the sombustion bed. which has onlr one to twn nercent. file1.

This bed is fluidized by a flow of combustion air from a gridplate below the bed. These two features are complementary in that the excellent mining of a fluidized bed is what allows such a large amount of inert bed material. In turn, this allows the temperature to be decreased without losing comblete combustion by providing a large thermal mass.

It is very convenient for this bed material to be limestone or dolomite. It then can react chemically with sulfur dioxide and allow its removal as a dry solid waste. The low temnerature is alsn imnnrtant. for decreasing thermal No formation. Finally, the low temperature and large amount of bed material serve to minimize the emission of trace metals from the coal combustion.

The large amount of bed material also allows heat transfer pipes to be located directly in the midst of the combustion zone. This gives a much more compact boiler which in turn decreases expenses.

The actual design of an FBC is still experimental. Development appears to be more advanced in England and Sweden where a few units have been placed in regular operation. In the U.S. the prototypes are still experiencing problems with coal feeding while many European units simply pour coal in the top. Nearly all of the American work has been done by Pope, 
Evans and Robbins, Inc. They have designed and built a Dor-funded conversiun of the 30-Mivesville plant to a FBC. This boiler will actually have three beds plus a carbon bumun cell. This improves turndown canabjijty by being able to turn one or tion cells off. The carbon burnuip cell is needed because the Rivesville beds only consume 83 percent of the fuel carbon. At a recent coal conference it was stated that this was inevitable and that industries might not require a burnup cell but that utilities definiteiy would for maximum efficiency. The problem of elutriation results from the poor Anerican design which uses too high an air velority. Furopean designs, on the other hand, do not require a carbon burnun cell. Iost estimates are that fluidized bed combustion will be available commercially by the midije to late 1930's, wich is discouragingly slow, considering the use of fluidized bed reactors in the chomben industry for decales.

\section{ENILANCED OIL RECOVERY}

At present the Pacific Gas and Flectric Conpany is negotiating with Getty and Texaco to install combustion turbine cogeneration systens of 330 and 27o yit capecity in fern county, California oil fields. The oil cominnies have been blocked from further develonnent of steam injection because of environmental constraints with respect to $\mathrm{SO}_{2}$ and $\mathrm{NO}_{\mathrm{x}}$ emissinns fron crude oil boilers. The economic situation discourages cleanup hy the oil conpanies so that the utilitjes, were approached with the offer of inexpensive oil in exchange for steam. Electricity generation in turn allows PGGE to invest in oil gasification and desulfurization equipment to meet emission constraints: This institutional arrangement provides energy, economic and environmental advantages and although no cogeneration systems have been installed at present, there is a significant potential in the future. $\Lambda$ s stated above PGGE is presently negotiating for $490 \mathrm{ilW}$ of baseload capacity, supplying $3.6 \times 10^{6} \mathrm{lbs} / \mathrm{hr}$ stean. This steam capacity is only one-fifth of the present steam generation in the three major Kern County oil fields (Kern River, Midway-Sinset and S. Belridge). Furthermore, there are several other significant heav' oil deposits as listed in Table E-3. 
The recoverable heavy oil figures given in Appendix $D$ (Tahle D-2) are conservative with respect to cogeneration potential because they consider only 1975 technologies and economics. This would be steam soak methods of recovering $\$ 5.25 / \mathrm{bbl}$ oil. Doubling the value of the oil will permit steam drive nethods and increase the recoverable reserves by 30-50 percent. On the other hand two-thirds of this oil will be recovered using steam while one-third will be recovered with $\mathrm{CO}_{2}$ flooding or detergent drives which do not use cogeneration. Finally, the list only considers the largest fields capable of supporting a 200-M cogencration plant for at least 15 years.

Obviously the potential for cogeneration is very large. Table $D-2$ (Appendix D) lists $4.7 \times 10^{9}$ recoverable barrels of heavy oil in California. Assuming that 40 percent is recovered by cogenerated steam drive over 20 years, production will be $96 \times 10^{6}$ bbl/year. If 50 percent is marketed, 15 percent converted to electricity, 25 percent converted to steam and 1 . percent lost, then generation will be 5500 l.w continuous for 20 years. Nationally the potential might be triple this amount.

The problem which needs to be addressed with respect to enhanced oil recovery cogeneration is whether the oil-fired combustion turbine system assumed in the example above is the most advantageous method. It is presently preferred by those contemplating the installation of the first oil field cogeneration: This, however, has been largely determined by the artificial economics of low first tier oil prices. At this point it is important to take a broader long-term view of the technical options available. Host important among these are combined cycle and closed cycle systems allowing the use of coal or possibly coal gasification. These systems may have slightly lower efficiencies, but more importantly, oil production will be doubled by the substitution of coal.

Oil fuel availability is obviously no problem, although át present the artificial pricing of oil has caused lower tier oil to be trucked to distant fields to avoid burning second tier oil for steam.

This institutional arrangement is for the benefit of the companies involved and may not be in the long-term public interest. For example, the large capital investment by the public utility with ratepayers' money depends upon the artificially depressed prices for first tier oil 
before it enters a refinery and requires entitlement payments to refineries buying foreign oil. This investment in crude gasification will be in jeopardy if the Federal government decontrols the price of first tier oil which in a fair possibility over a period of 20 years.

An energy flow diagram for the oil-based system is presented in Figure E-1 based on preiiminary equipment specifications of PGE्E. This included large GE frame 7000 turbines rated at $75 \mathrm{MW}$. In assessing the enhanced recovery industry energy profile, it will be necessary to consider a range of engines including smaller, less efficient ones which may be appropriate in other locations: This information includes empirical data on the performance of various engines as a function of fuel, cemperacüe and load. Portunately the load characteristics of enhanced recovery are simple and stable over time (years). Thus the duty cycle will be based primarily on the opt imum maintenance schedule. The process used in this case allows for daily fluctuations in steam production without interfering with oil production. It is important to maintain a high pressure ( 900 psi), but steam quality is not critical and 80 percent vapor is considered satisfactory. The water content is important to prevent scaling because of poor water quality.

With respect to environmental constraints, the role of cogeneration is positive compared to the existing boilers burning crude oil without controls. Al1 of the major combustion turbines with gaseous fuels can meet the New Source Performance Standards promulgated by the EPA for gas turbines last fall. At the state and local level, Kern county is a non-attainment area with respect to some ambient air quality standards $\left(\mathrm{NO}_{x}, \mathrm{SO}_{2}\right.$ ). Fortunately New Source Review procedures now allow pollution tradeoffs which are abundantly available from the existing dirty boilers to be retired. Future investigation should indicate the possibilities for increasing steam and oil production while decreasing pollution emissions.

Operational residuals and capital requirements for the described enhanced oil recovery system are listed in Appendix A. Appendix I contains a description of the capital residuals for the cogeneration systems. 


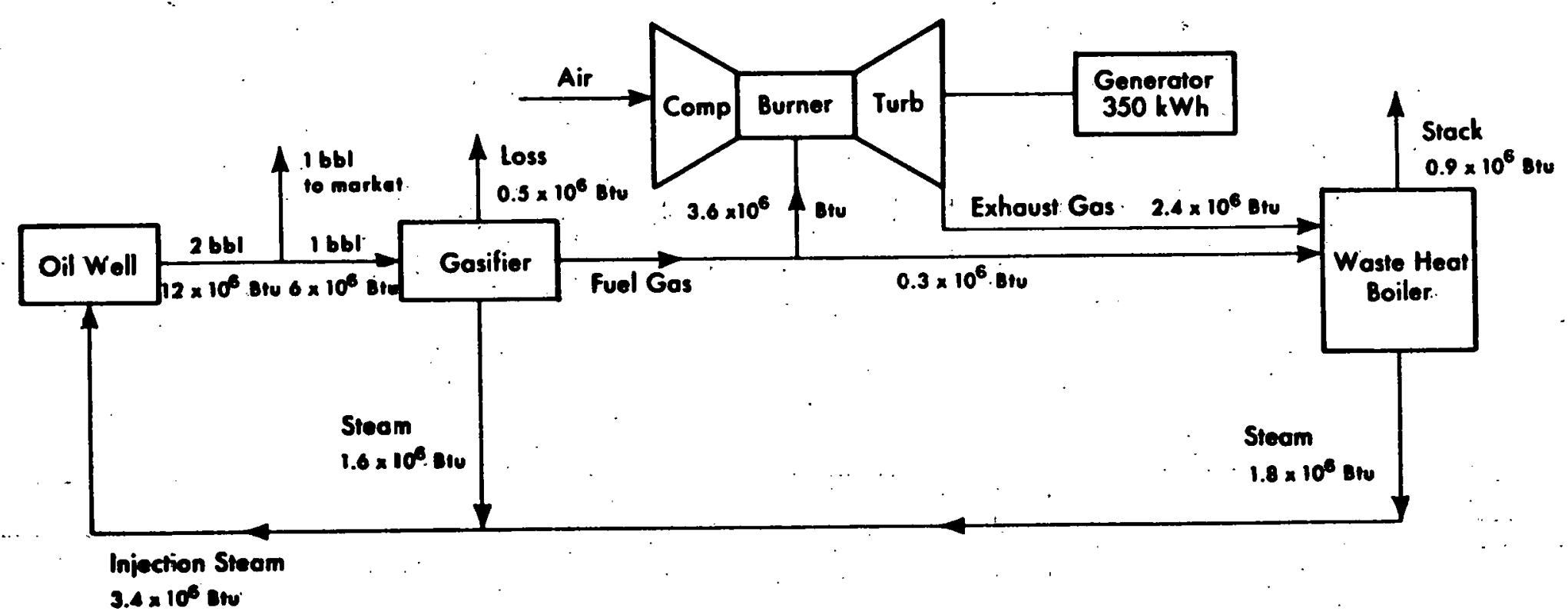

X8L 7810-11655

Fig. E-1. Energy Flows for Thermally Enchanced Oil Recovery Cogeneration ${ }^{2}$ 


\section{APPENDIX F \\ DIRECT COMBUSTION SYSTEMS}

This appendix provides additional information on the characteristics of direct combustion systems to that included in the body of the report. Its purpose is to clarify the information contained in the Technology Application section and to provide important information concerning Direct Combustion systems which is not required for SEAS input through the TASE program.

A genera1 schematic diagram for MSW direct combustion systems is shown in Figure F-1. Some systems, include coarse shredders, while some screen incoming. MSW and shred only oversized material; many systems include no front end processing at all. As briefly described in the Technology Application section of this report, incinerators are either of a refractory wall or of a waterwall type. Refractory wall incinerators require the use of a boiler or of an afterburner to complete combustion followed by a boiler, to produce the basic system product: steam. This steam may either be converted to electricity or used directly for industrial process or district heating applications while the waste ga'stream is treated and released from the plant stacks.

A general comparison of waterwall and refractory wall systems is shown in Table F-1. Refractory systems tend to require more excess air and generate a higher volume of $\mathrm{H}_{2} \mathrm{O}$ in the off-gasses, both of which decrease the desirability of the refractory wall system. Further, refractory wall incinerators burn at a much lower temperature than waterwall systems. It should be noted that while these temperatures are comparable to RDF systems, they are well below that of pyrolyziz systems, which have reaction temperatures of $900^{\circ} \mathrm{F}-3000^{\circ} \mathrm{F}$.

The simplicity of both of these types of systems and their use of existing technology has accounted for the interest in and adoption of direct combustion systems as indicated in Appendix C. However, there are two major disadvantages to direct combustion systems which limit the future attractiveness of this technology relative to RDF and pyrolysis systems. These are: 


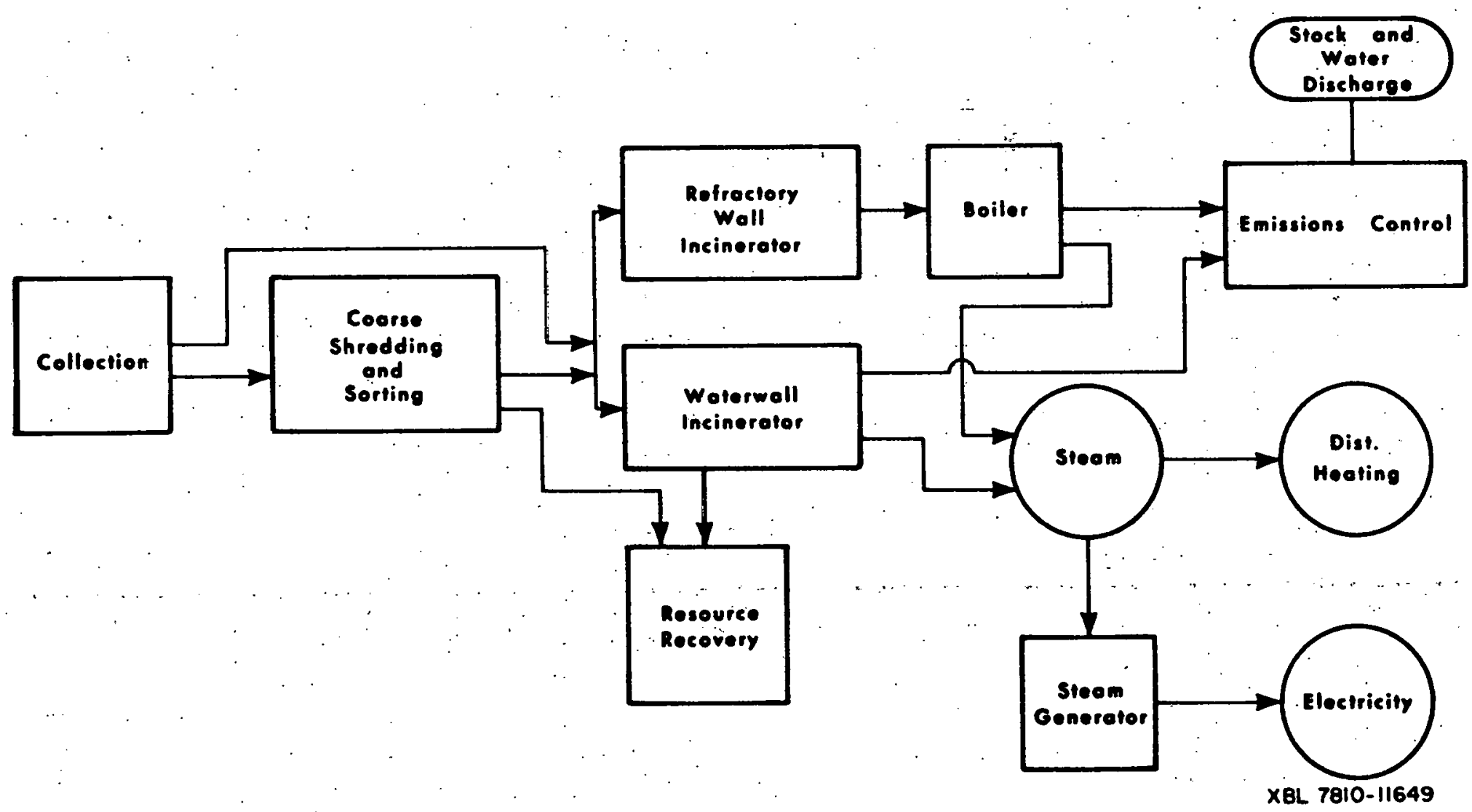

Fig. F-1. MSW Direct Incineration 
Table F-1.

T)jical Gas Compositions for Conventional and stcam-fenerating Incinerators

\section{Type of Incinerator: \\ Refuse Firing Rate, $M / \mathrm{T} / \mathrm{hr}$ (ST/hr) \\ Air Cooling/Air Cleaning :lethod \\ Excess $\lambda$ ir, :}

Stach Exhaust

Temierature, ${ }^{\circ} \mathrm{C}\left({ }^{\circ} \mathrm{F}\right)$

Volume : $\mathrm{C}_{2}$, wet basis (dry basis)

Volame? Oa, wet hasis (dry bașis)

Volume $i \mathrm{~N}_{2}$, wet basis (dry basis)

Volume : $\mathrm{l}_{2} \mathrm{O}$, wet basis

Flow, Cl/min e temperature (ACF:l a temperature)
Waterwa11

$15.2(16.7)$

Boiler/Flectrostatic Precipitator

71.7

211 (111)

$9.1 \cdot(10.5)$

?. (?.)

$69.3(30.5)$

13.3

$2400 ? 211^{\circ} \mathrm{C}$ $\left(84,700: 411^{\circ} \mathrm{F}\right)$
Refractory

9.4 (?.2) (nating) is

Caustic Scrubber

180 (estimatcr)

$57-77(1.35-179)$

$3.7-3.2(1.8)$

$10.1-3.600 .3$

$64.2-54.2(32.2)$

$22-34$

$2119 \approx 77^{\circ} \mathrm{C}$

$\left(74,800 \therefore 170^{\circ} \mathrm{F}\right)$ 
1. Large volunes of excess air are required to ensure complete burning and to maintain desired incinernator temperature. As a result, the volume of dry flue gas is dramatically increased as shown in Figure F-2. The required large air flows dictate the use of large fan systems, larger stacks, larger precipitators and/or scrubbers, and decreased precipitator efficiencies (Waste Age, March 1975).

2. MSW incineration tends to increase pipe, refractory and lining fouling and corrosion when compared to other steam-producing fuels (Govan, Martin and Monro, 1974). The high fly ash content of MSW off-gasses tends to coat waterwall and superheater pipes and thus reduce heat transfer efficiency. High PVC and rubber content in MSW will increase chlorine corrosion of metal tubes and pipes (Govan, Martin and Monro, 1974).

A third type of direct combustion systems not shown in Figure $F-1$ are the modular systems. These systems typically have a capacity of less than 50 TPD and use an incinerator-afterburner-boiler flow rather than a waterwall system. Modular systems therefore closely resemble a refractory wall incinerator in operational characteristics, except that burning is split between the incinerator and a gas-fired afterburner, where sufficient excess air is injected to complete the burning process, and that the modular systems are designed for low flow applications (refractory wall and waterwall incinerators are now being designed in the thousands of tons per day, while modular systems are designed for 30-50 tons per day).

Even though there are differences between the refractory wall and waterwall operation, and between modular systems and each of the other two types, the three systems are similar with respect to conversion efficiencies: and to residual generation rates (Schoenberger, Wohlers and Jackson, 1970; Combustion Power Company, 1977). Because of its advantages relative to refractory wall systems and because of its greater system simplicity, a waterwall incinerator system has been selected for model application in this study. A material, capital and energy input/output summary for a typical waterwall incinerator is included in the Technology Application section. A material balance is shown in Figure F-3. The system energy balance is shown in Figure F-4. Data for Figures F-3 and F-4 were obtained from a critical synthesis of the data contained in: 


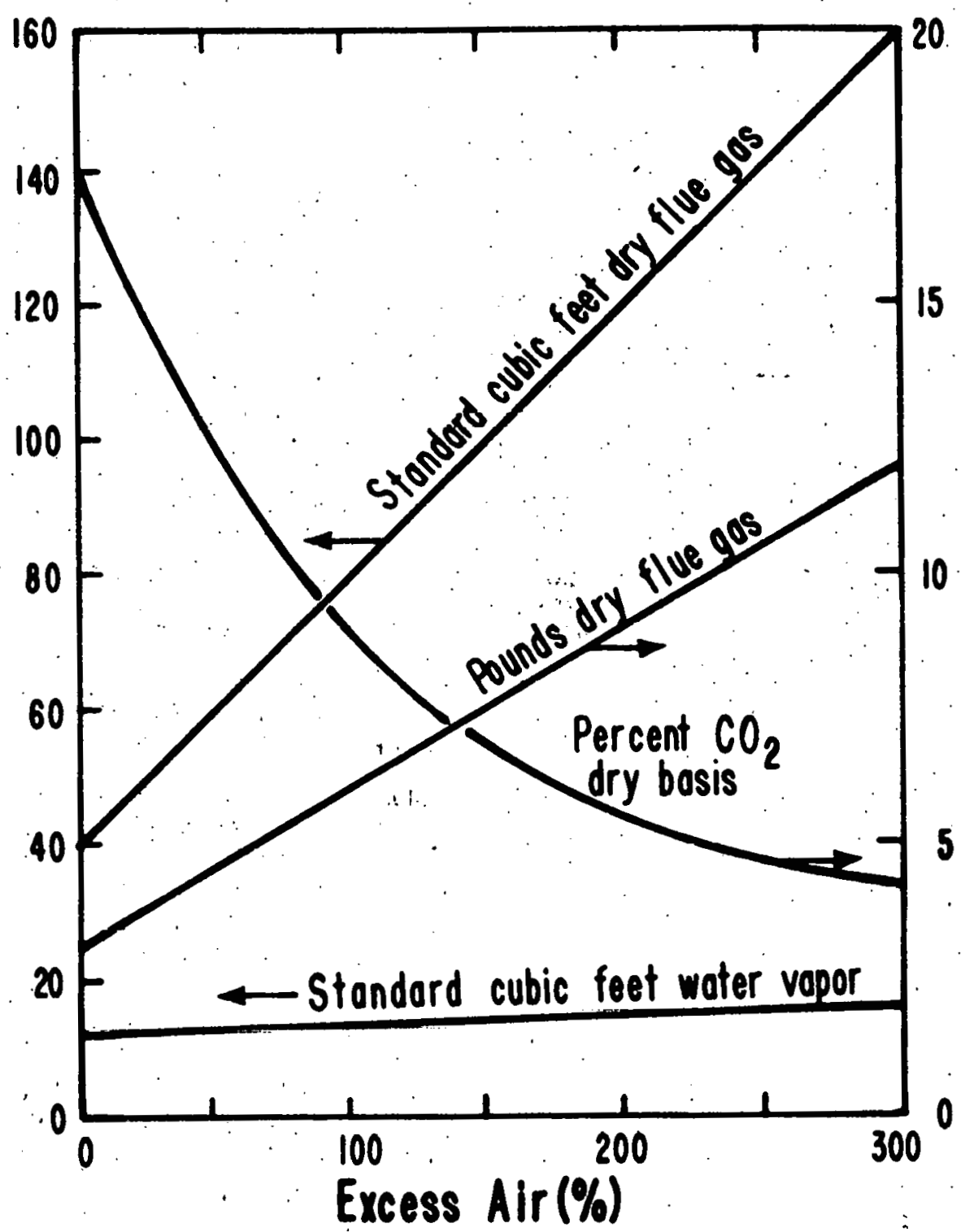

XBL 7810-11647

Fig. F-2. Incinerator. Flue Gas Volume as a Function of $q$ Excess Air (from Weinstein and Toro, 1976) 


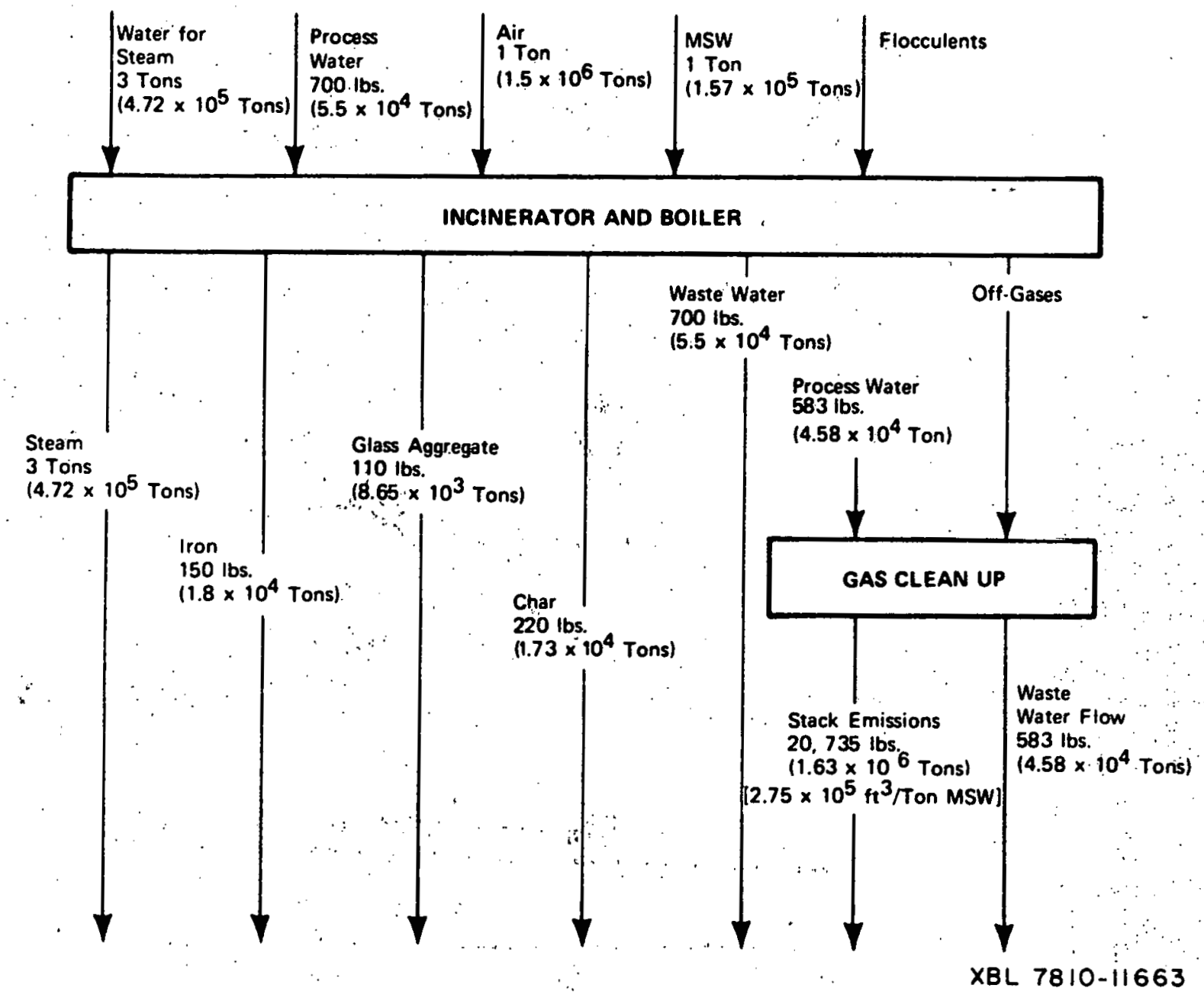

Fig. F-3. Direct Combustion Material Balance 


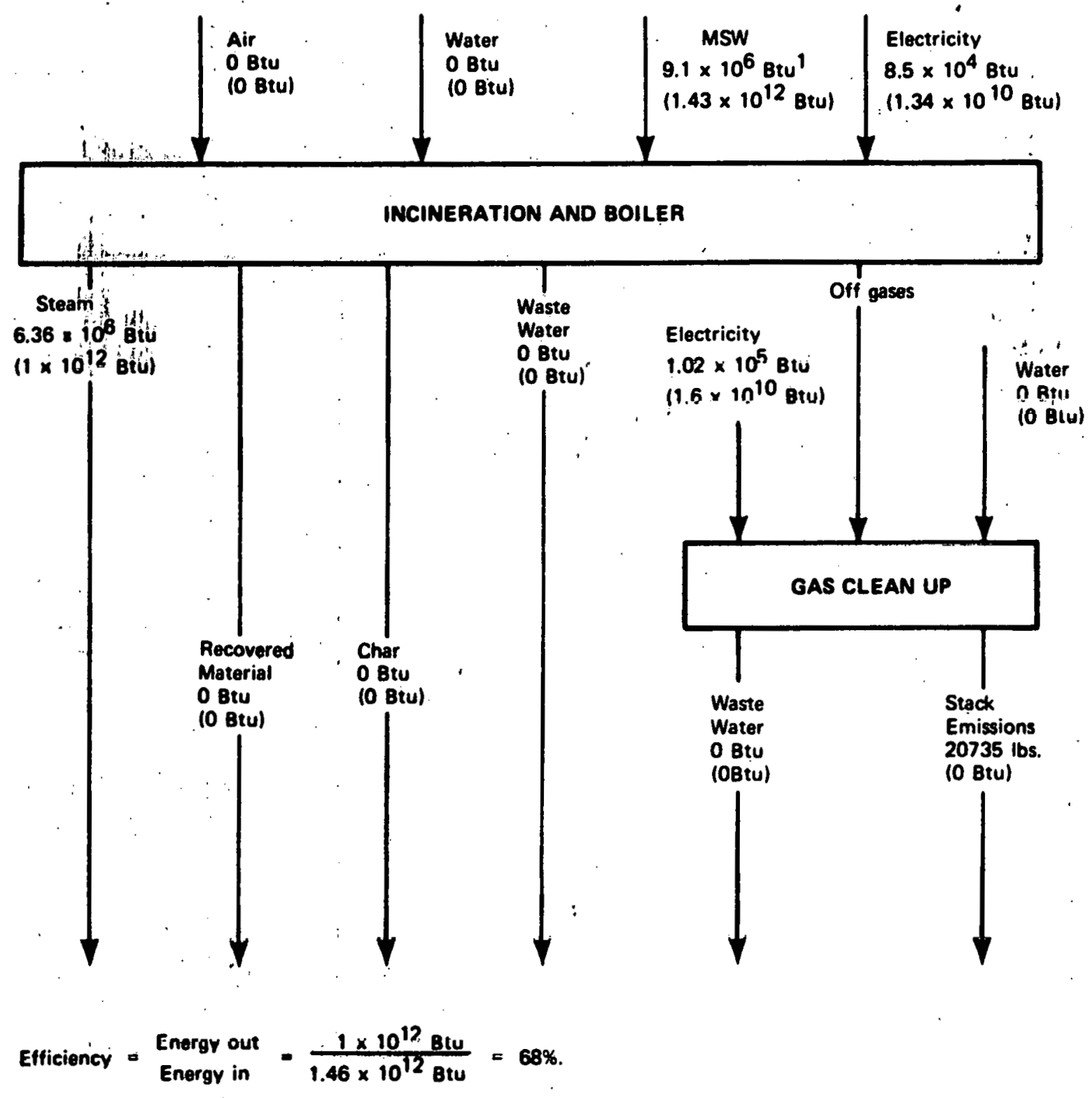

'Numbers give amount per ton of MSW and (amount per $10^{12}$ Btu output).

XBL $7810-11659$

Fig. F-4. Direct Combustion Energy Balance 
Gowan, Mart in and Monro, 1.974; Moore, 1967; Lawler, 1975; Kaiser, 1976 and 1976a; University of California; 1951; Ongerth and Tucker, 1970; Bishop and Deming, 1967; and Hahn, 1970. A 1000 TPD plant following the schematic shown in Figures F-3 and F-4 will produce $1.946 \times 10^{12}$ Btu of steam per year working at an 85 percent on-line rate. This MSW would then replace approximately 97,500 tons of coal per year which would otherwise be required to produce industrial quality steam.

Determination of the fossil fuel equivalency of MSW for a direct combustion system is depicted in Figure F-5. The design end use for the direct combustion energy product is industrial process steam. Direct MSW combustion incinerators produce relatively low pressure (150 psi to $500 \mathrm{psi}$ and low temperature $\left(400-600^{\circ} \mathrm{C}\right)$ steam. In order to produce. the same $1 \times 10^{12}$ Btu of industrial steam, $1.25 \times 10^{12}$ Btu of fossil fuel would be required. If, however, MSW-produced steam is converted to electricity as an end use product, only $5.1 \times 10^{11}$ to $7.1 \times 10^{11}$ Btu of coal will be replaced by the MSW system. Assumed system efficiencies for all processes are shown in Figure $F-5$. MSW conversion efficiency is calculated from Figure F-4. 
Process efficiency
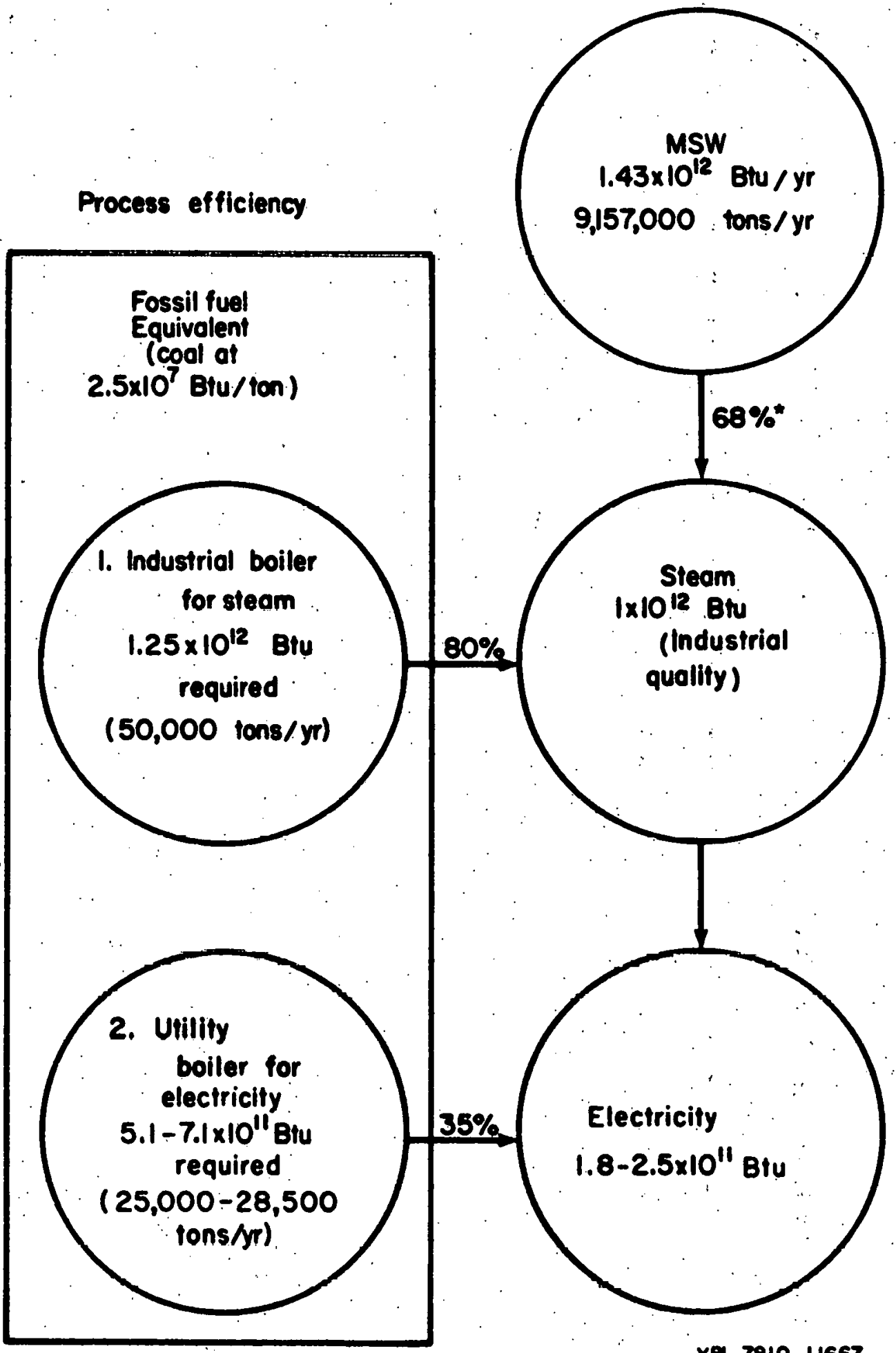

"process efficiency

Fig. F-5. Fossil Fuei Equivalency for MSW Direct Time Systems 


\section{REFERENCES: APPENDIX F}

Bishop, J.W. and L.F. Deming, 1967. "Economics of Solid Waste Incineration," in (R. Fox, editor), Proceedings of the Mecar Symposiumof Solid Waste, 1967.

Combustion Power Company, Inc., Final Report for the CPU-400 Pilot Plant Integration and Operation., 1977.

Govan, F.A., D:" Martin and R.J. Monro, "The Combustion of Municipal Solid Waste as a Primary Fuel," in (D.E. Earley et al., editor) Energy and the Environment, Proceedings of the Second National Conference, American Institute of Chemical Engineers, 1974.

Hahn, J.L., Study of Delaware County No. 3 Incinerator in Broomal1, Pennsylvania, U.S. Environmental Protection Agency, 1970.

Kaiser, E.K., "Refuse Reduction Processes," in (L. Weaver, editor) Proceedings: 'The Surgeon' General's Conference on Solid Waste Management for Metropolitan Washington, held July 19-20, 1967, U.S. Department of Health, Education and Welfare, 1967.

Kaiser, E.R., "Composition and Combustion of Refuse," in (R. Fox, editor) Proceedings of Mecar Symposium-Incineration of Solid Waste, 1967a.

Lawler, S.P., "The Americology System (Milwaukee)," in (S.M. Barnett et al., editors) Energy from Solid Waste Utilization, Proceedings of the Sixth Annual Northeastern Regional Anti-Pollution Conference, 1975 .

Moore, H.C., "Refuse Fire Steam Generator at Navy Base, Norfolk, Va.," in ( $R$. Fox, editor) Proceedings of the Mecar Synposium-Incineration of Solid Waste, 1967 .

Ongerth, J.E. and M.G. Tucker, Report on a Study of the Weber County Incinerator in Ogden, Utah, U.S. Environmental Protection Agency, 1970 .

Schoenberger, R.J., H.C. Wohler and W. E. Jackson, Jr., "Regional Air Quality Contro1-The Impact and Cost of Refuse Incineration," Presented at the ASME Winter Annual Meeting, New York, NY, November 29, 1970.

University of Calfornia, Municipal Incineration, SERL Technial Bulletin No. 5, 1951.

Weinstein, N.J. and R.F. Toro, Thermal Processing of Municipal Solid Waste for Resource and Energy Recovery, Ann Arbor, MI: Ann Arbor Sciences, 1976.

Anonymous, "The East Hamilton Solid Waste Reduction Unit-SWARU," Waste Age, March 1975 . 
APPENDIX G

CHARACTERIZATION OF RDF

The chemical composition of RDF determines not only its heating value but also its, emission control problems: Table G-1 provides a com-" parison of the typical composition of raw refuse and RDF using reasonable estimates for non-site specific analysis. The chemical composition for "; air-classified RDF (as used by Union Electric at St. Louis and by the city of Ames) and the wet-pulped RDF (Black Clawson fuel) is shown in comparison with coal in lable G-2.

The pollution problems of sulfur, nitrogen, ash and chlorine prevail for each fuel. The amount of sulfur in refuse fuels is significantly lower than coal. It is expected that there will be no difficulty in achieving the sulfur standards established for stationary sources. Nitrogen levels are also lower than those of coal and should pose no serious problems that could not be controlled. There is typically twice the ash content in RDF as there is in coal. The overall effects of ash are to increase operating and capital costs due to handling of bottom and fly ash. Increased ash levels may result in additional residuals in the air emission and boiler residue which will require further process control. The chlorine content of RDF is also enhanced because of the presence of plastics in the combustible fraction. The potential environmental impacts related to the pollutants listed above are discussed in another section (Environmental Data).

The materials and energy balance for a typical RDF system are shown in Figures G-1 and G-2. The values shown are amount per ton MSW input. In addition, in the materials balance diagram the amount-per-10 $12-B t u$ of output is also included. 
Table G-1

Comparison of Raw Refuse and RDF

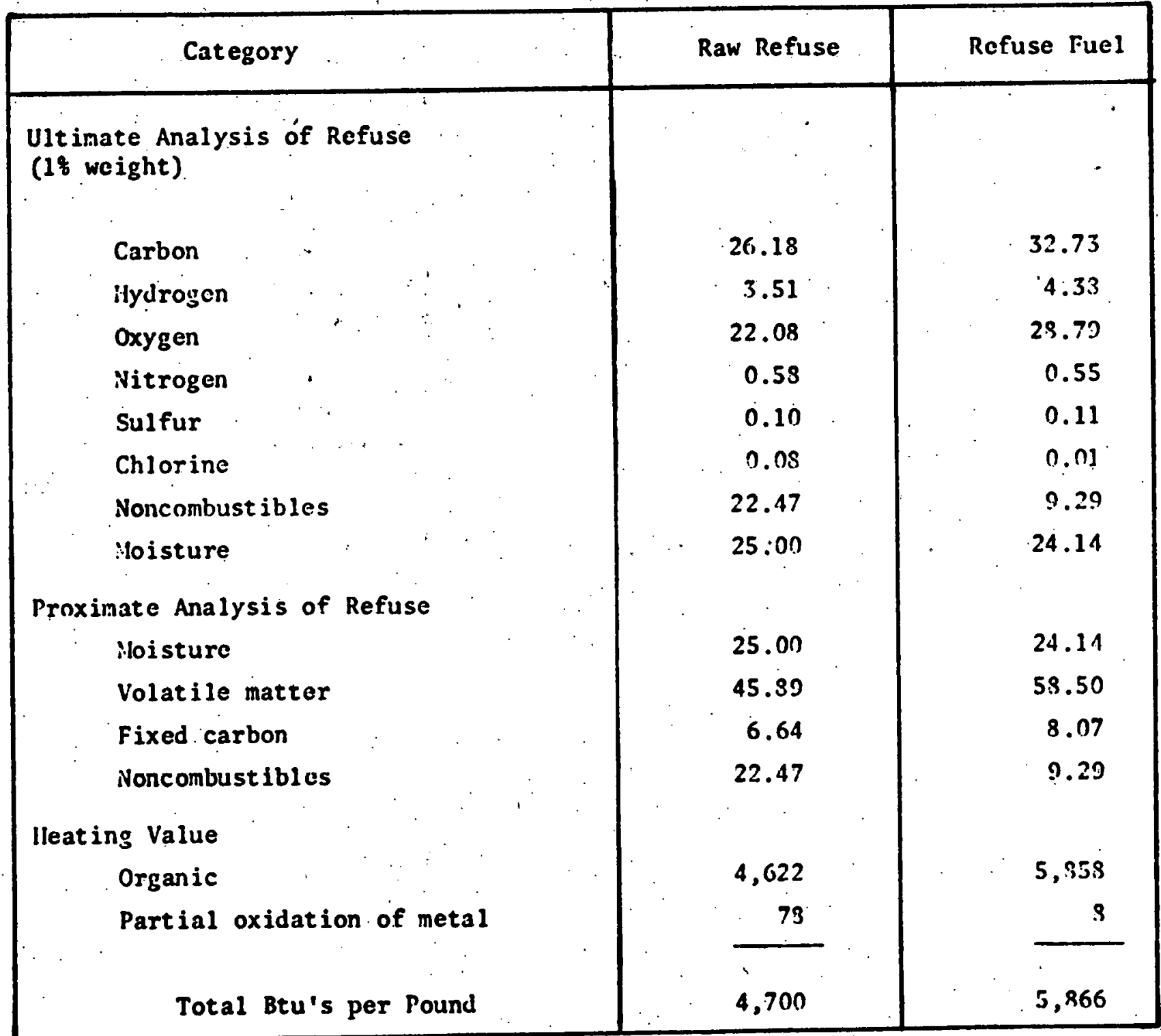

Source: Barnett, S.M. et al., Energy From Solid Waste Utilization, Proceedings of the Sixth Annual Northeastern Regional Anti-Pollution Conference, University of Rhode ls land; July 8-9, 1975. 
Table G-2

Comparison of the Chemical Composition of Fuels

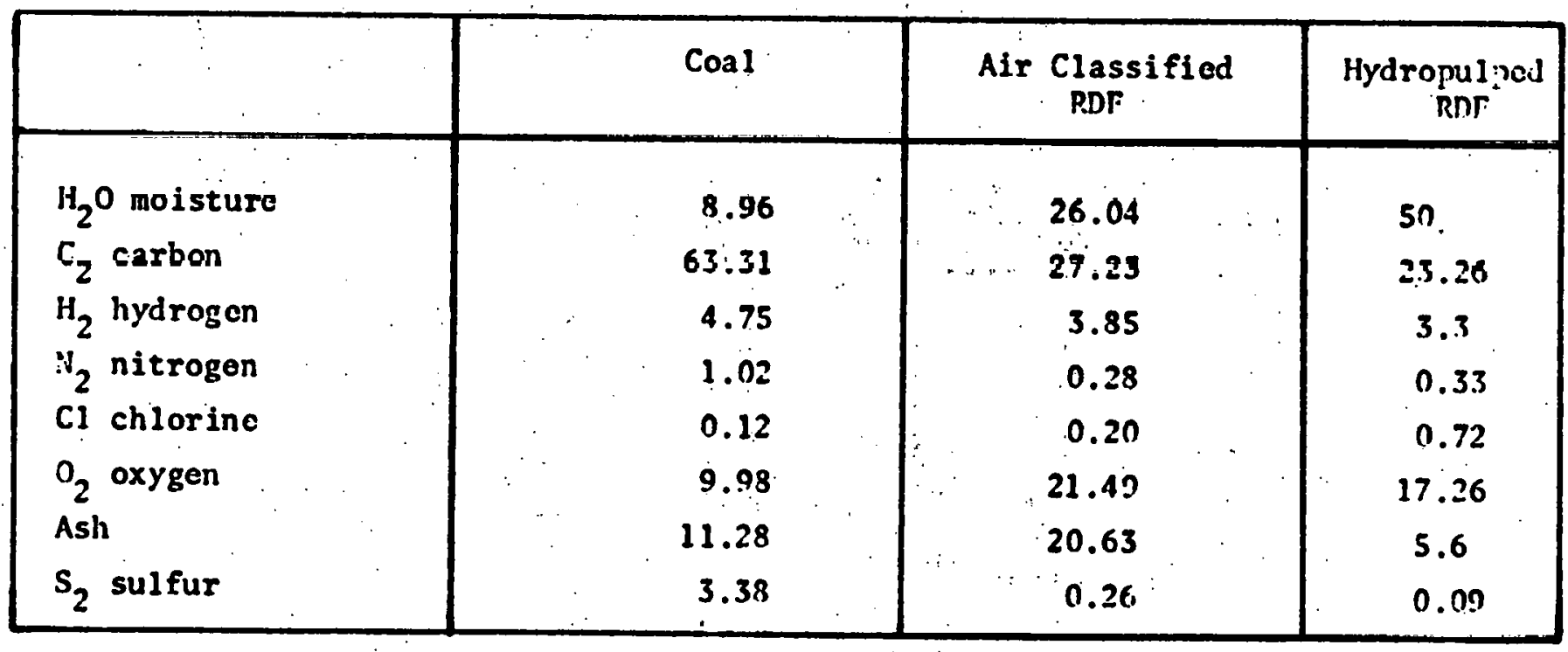

Source: Environmental Science \& Technology, May 1.875. 


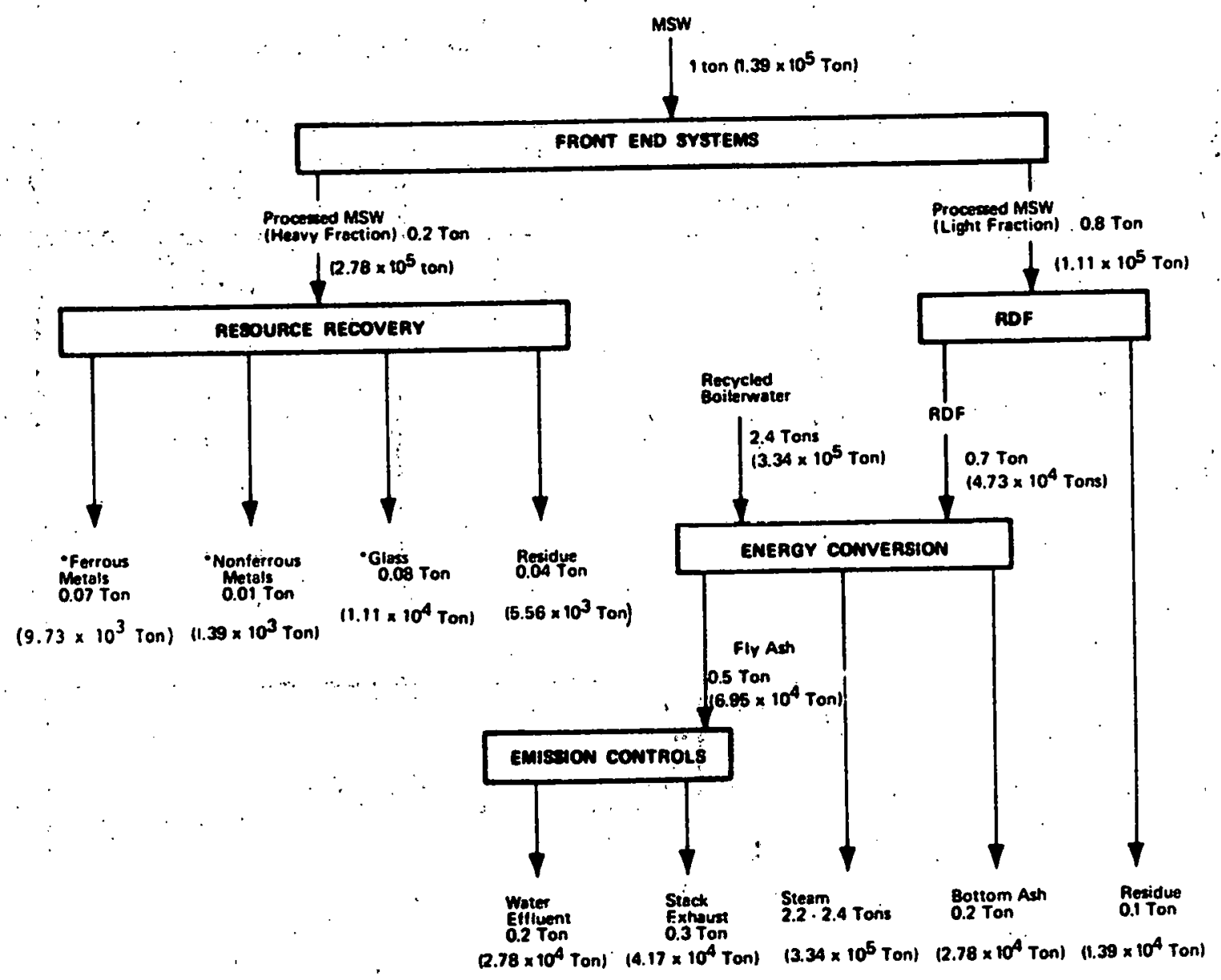

QValues shown as amount per ton MSW inpul and (amount per $10^{12}$ Btu of output).

- Potentially recoverabla materials.

XBL $7810-11657$

Fig. G-1. RDF System-Materials Balance ${ }^{a}$ 


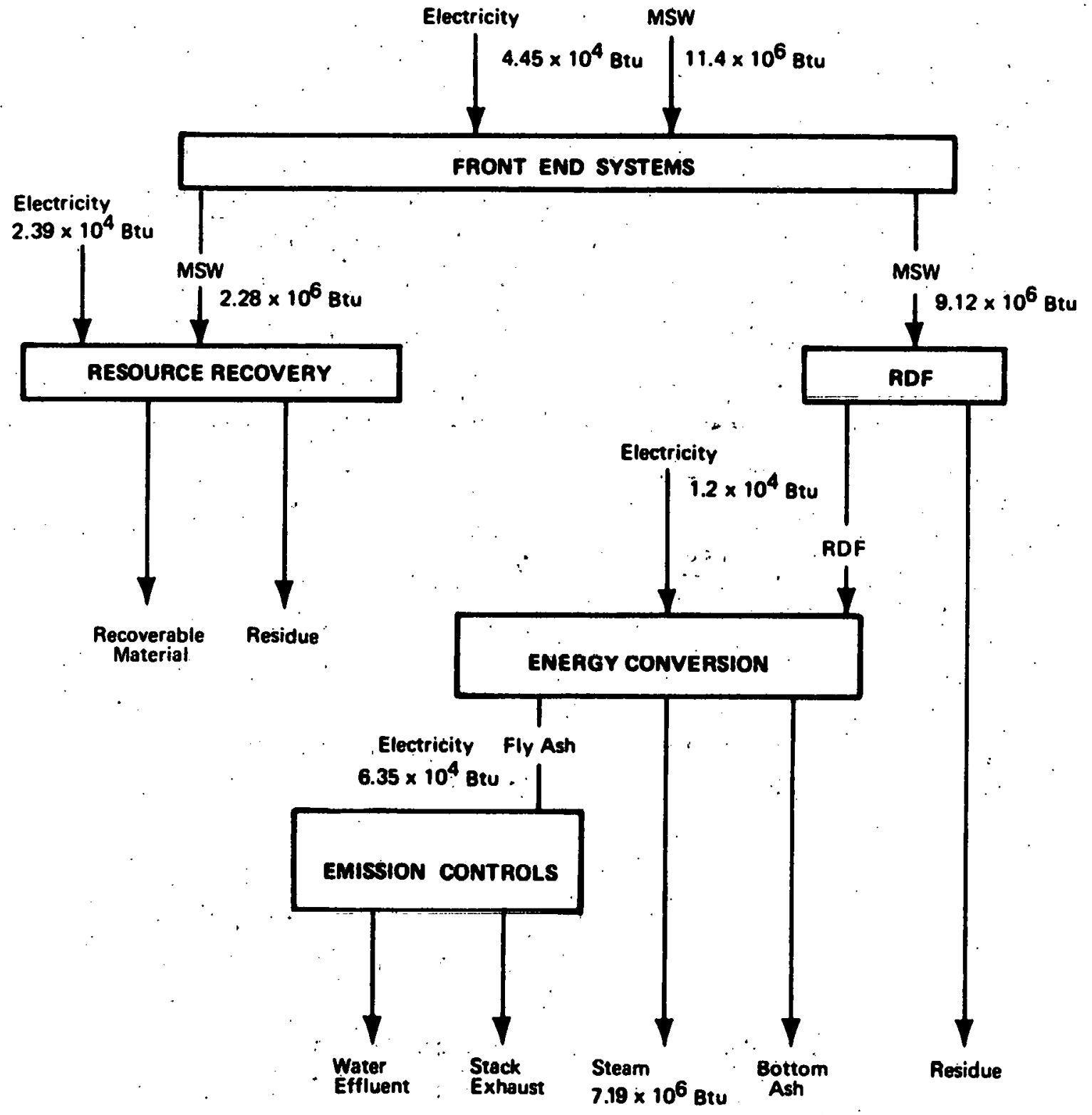

Recovery Efficiency $=\frac{\text { Steam Energy Out }}{\text { MSW Energy in }}=\frac{7.19 \times 10^{6} \mathrm{Bty}}{11.4 \times 10^{6} \mathrm{Btu}}=0.631$

${ }^{8}$ Values shown as Btu per ton MSW input.

XBL 78.10-11656

Fig. G-2. RDF System Energy Balance 
APPENDIX $\mathrm{H}$

PYROLYSIS CONVERSION OF MSW

This appendix contains additional information on pyrolysis energy recovery systems to that contained in the Application and Environmental Data section of the report. Specifically, limited information on the basic chemistry of pyrolytic reactions, an expansion of the advantages and drawbacks to pyrolytic systems, additional description data on the PUROX sytems, and general descriptions of the Iandguard and Garrett Research processes are included.

\section{Chemistry of Pyrolysis}

The elemental composition of the organic fraction of MSW roughly approximates that of cellulose which can be chemically represented as $\left(\mathrm{C}_{6} \mathrm{H}_{10} \mathrm{O}_{5}\right)_{n}$, where " $n$ "indicates the number of basic chemical units (Weinstein and Toro, 1976). With this approximation a simple pyrolytic reaction can be represented as (Weinstein and Toro, 1976):

$$
\begin{aligned}
\text { MSW } \equiv & \mathrm{C}_{6} \mathrm{H}_{10} \mathrm{O}_{5} \stackrel{\text { heat }}{\rightarrow} \text { fuel gas with } \mathrm{CO}_{2} \text { and } \mathrm{H}_{2} \mathrm{O}+\text { pyrolytic oil } \\
& + \text { other condensibles + carbonaceous solid residue }
\end{aligned}
$$

The relative yield of each of these basic product components is dependent upon the specific characteristics of the input MSW and upon the control conditions of the pyrolysis reaction. The primary control conditions include temperature, pressure and the use of catalysts or oxydizing agents: The relative product mix is most sensitive to the reaction temperature, and, in fact, this control is used to separate gasproducing from oil-producing pyrolytic systems. The effects of temperature variation on the resulting product $\mathrm{mix}$ and product gas composition are shown in Table $\mathrm{H}-1$ and Figure $\mathrm{H}-1$, respectively. The relative product mix from a typical pyrolytic reaction is shown in Table $\mathrm{H}-2$. 
Table $\mathrm{H}-1$

The Effect of Temperature on Pyrolysis Yields

(Weinstein and Toro, 1976)

\begin{tabular}{|c|c|c|c|c|}
\hline Pyrolysis Temperature, ${ }^{{ }^{\circ} \mathrm{C}}$ & $\begin{array}{c}482 \\
(900)\end{array}$ & $\begin{array}{c}649 \\
(1200)\end{array}$ & $\begin{array}{c}816 \\
(1500)\end{array}$ & $\begin{array}{c}927 \\
(1700)\end{array}$ \\
\hline $\begin{array}{l}\text { Product Yields, } \\
\text { weight } \%\end{array}$ & & & & ؛ \\
\hline Gases & 12.33 & 18.64 & 23.69 & 24.36 \\
\hline Volatile Condensibles ${ }^{a}$ & 43.37 & 29.20 & 47.99 & 46.96 \\
\hline Other Condensibles & 17.71 & 9.98 & 11.68 & 11.74 \\
\hline Char & 24.71 & 21.80 & 17,24 & 17.57 \\
\hline$i$ & 98.12 & 99.62 & 100.60 & $100: 73$ \\
\hline
\end{tabular}

Pyrolysis System Advantages and Drawbacks

Pyrolysis systems have several key general advantages over other systems. Briefly, these include: fuel compataibility (pyrolytic fuel can be varied between oil and gas and can be subsequently converted to methanol, ammonia or other end use products); gaseous emissions can be minimized by collecting the off-gasses as an energy fuel; the processes are efficient and economical to run. General drawbacks include high capital costs and high corrosion and deposition rates on refractory walls and waterwall boiler tubes.

Advantages and disadvantages of specific pyrolysis systems are shown in Table $\mathrm{H}-3$. Based largely on this tabular comparison, the PUROX system was selected as the model application.

\section{PIIROX System}

A basic description of the PURUX system is contained in the Applications section of the report. This section presents supplemental information on the characteristics of the systems, its products and on the mass and energy flows through the systejus.

An average analysis of the PUROX product gas is shown in Table $\mathrm{H}-4$, and a comparison of this fuel with other common gaseous fuels is shown in Table H-5. Average composition of the slag aggregate is shown in Table H-6. This aggregate is suitable for sale to various industries including road construction. 


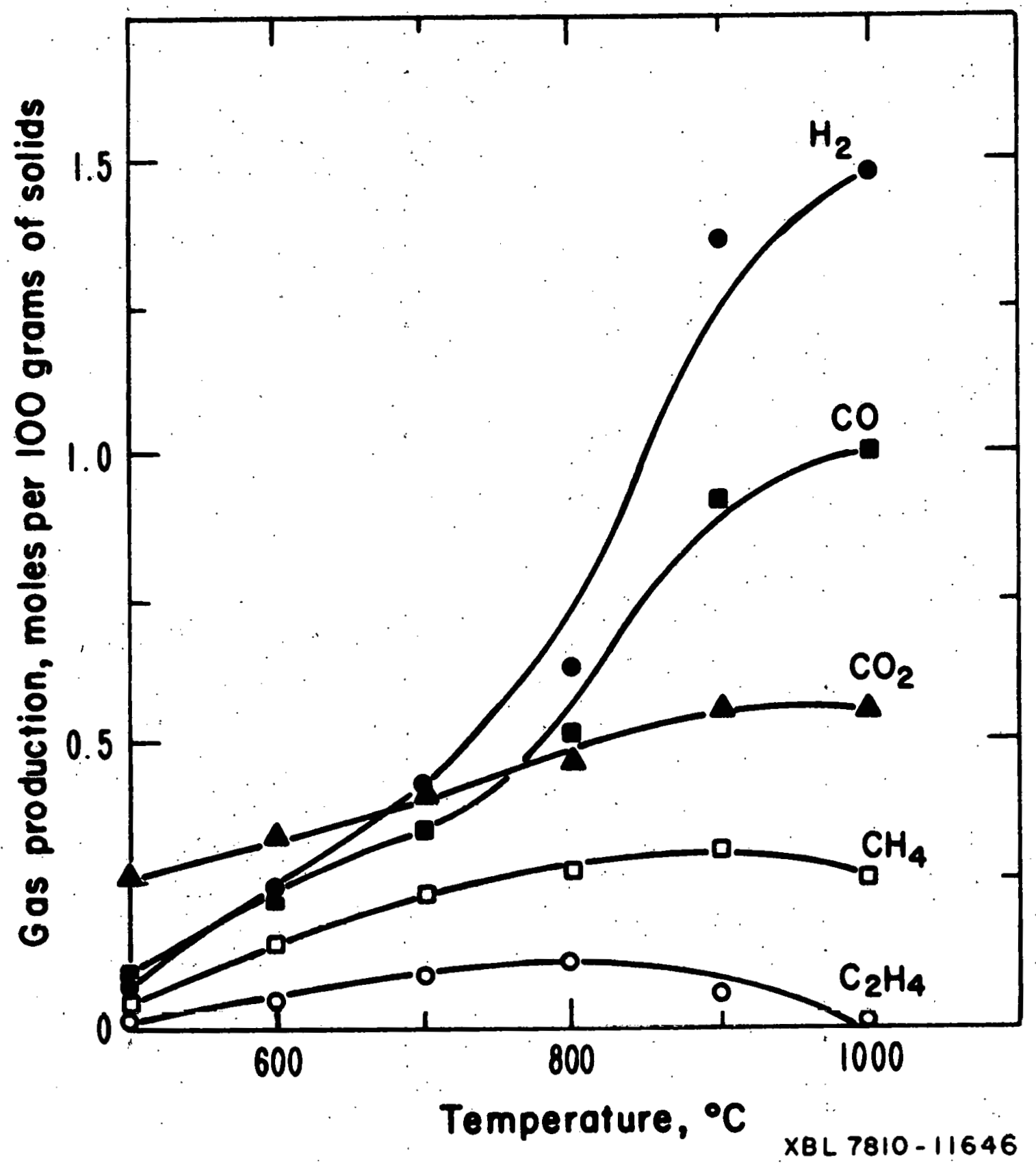

Fig. H-1. Gas Production-Laborafory Pyrolysis of Municipal Solid Waste

\footnotetext{
1 from McFarland, J.M., 1972.
} 
Table H-2

Simple Pyrolysis

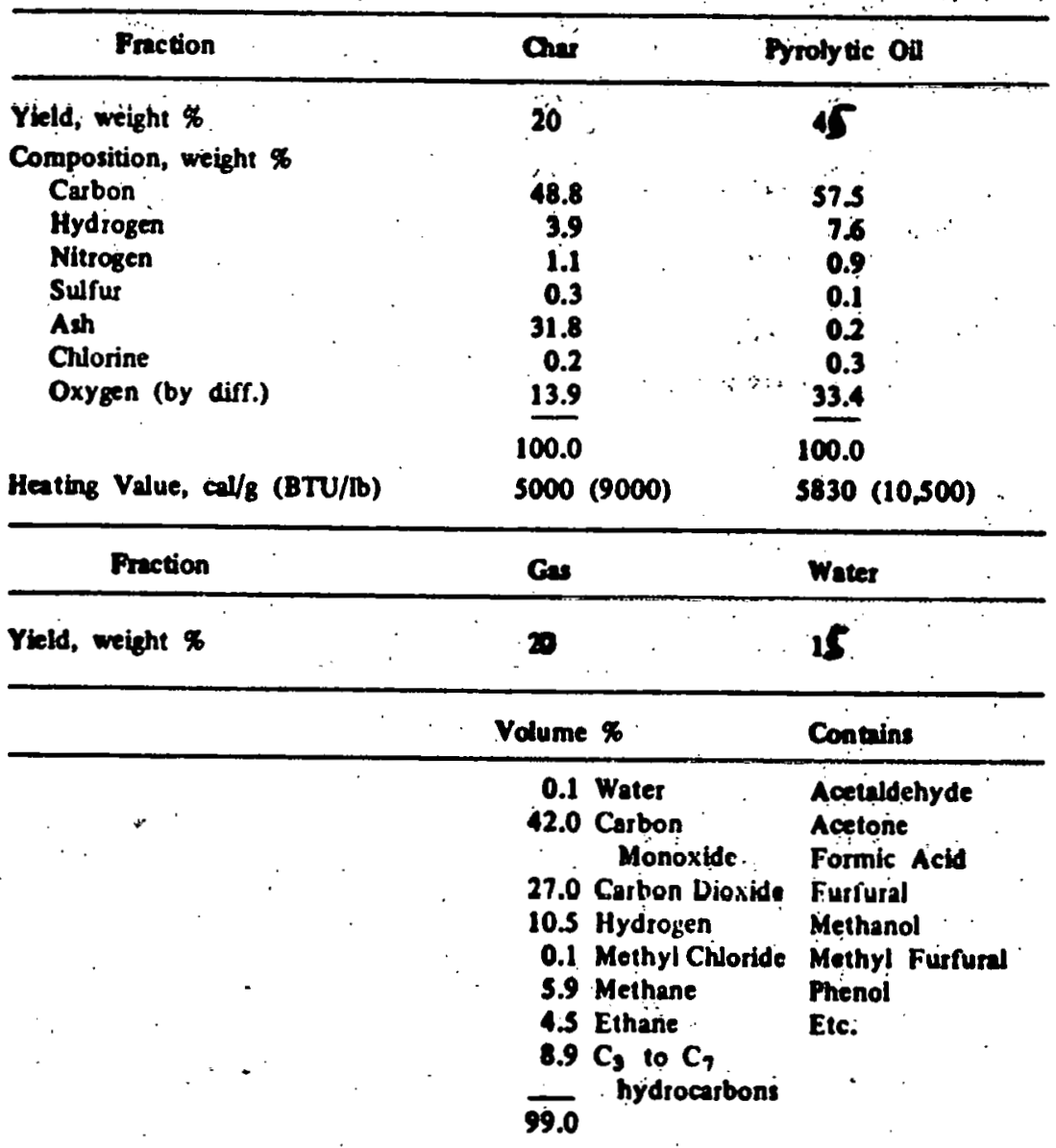


Table H-3

\section{Advantages and Drawbacks of Pyrolysis Systems}

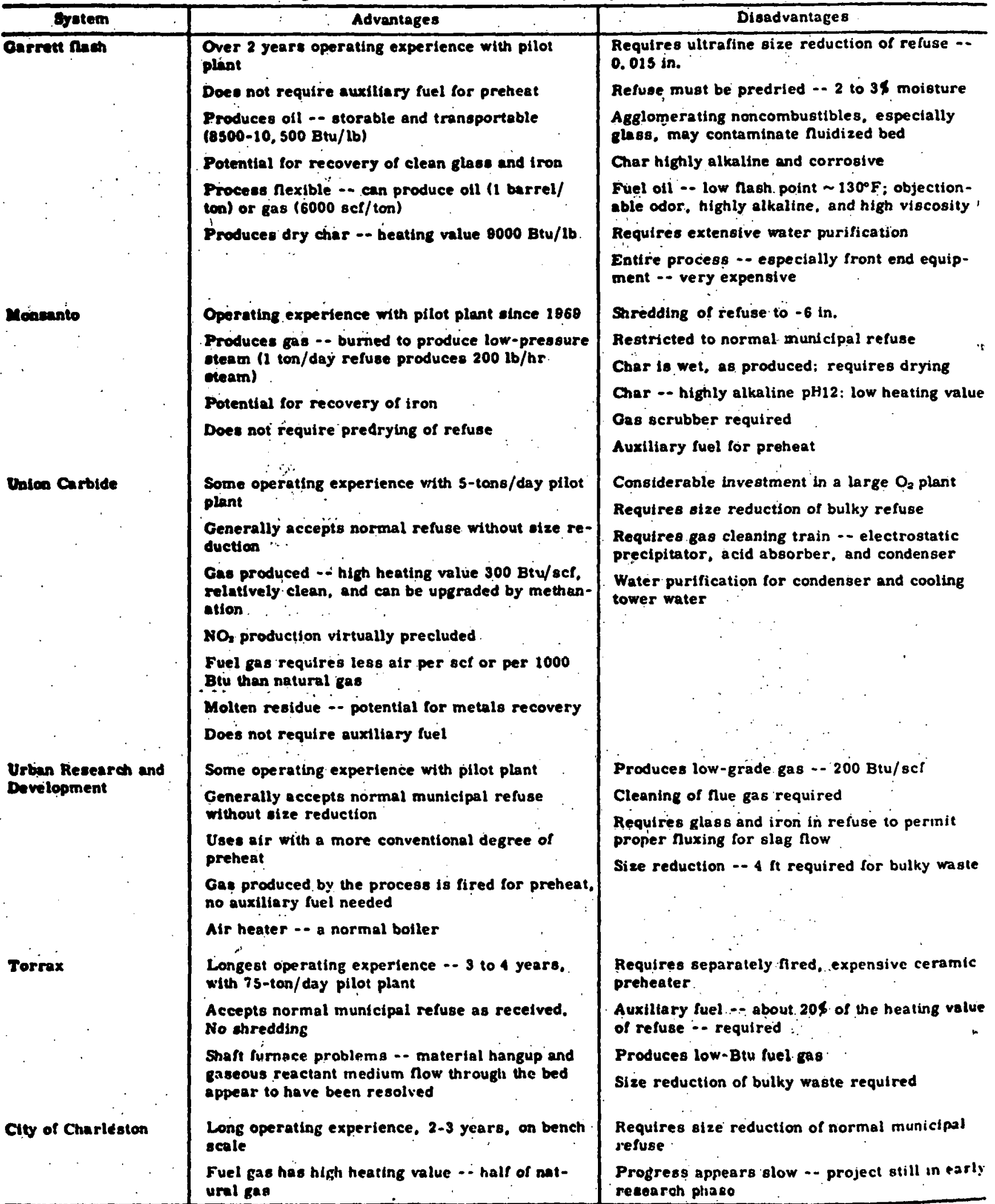


Table $\mathrm{H}-4$

Typical PUROX Fuel Gas Analysis

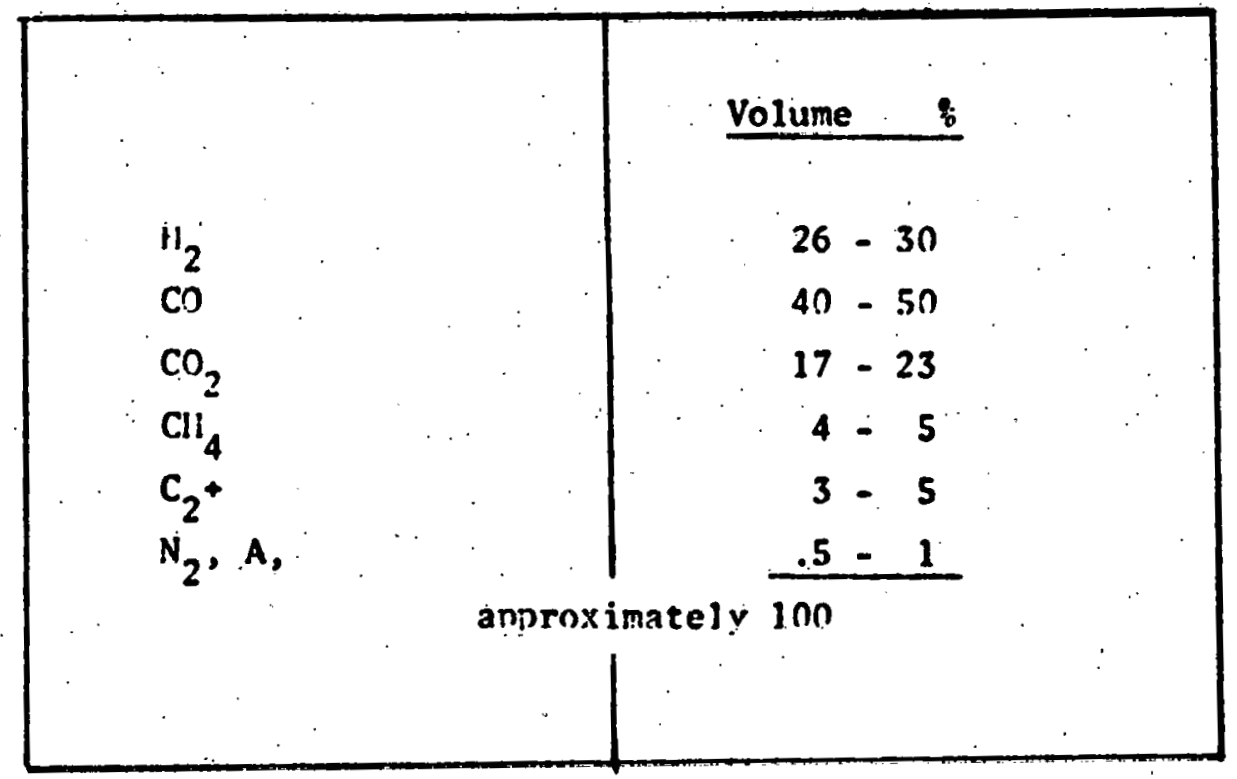

From: Bonnet, 1975 
Table H-5

Comparison of PUROX 'Gas and Other Gaseous Fuels 1

\begin{tabular}{|c|c|c|c|c|}
\hline$\ldots \therefore$ & $\begin{array}{l}\text { PIIROX } \\
\text { Fuel Gas }\end{array}$ & $\mathrm{CII}_{4}$ & $C_{3} ! I_{3}$ & $C_{1}: 10$ \\
\hline $\begin{array}{l}\text { Btu/sce } \\
\text { Compression Power }{ }^{2} \text { (!nhr/mm Btu) } \\
\text { Combusion air } \\
\quad \text { requirement (SCF/mm Btu) } \\
\text { Volume of Combustion } \\
\quad \text { Products (SCF/mm Btu) } \\
\text { Heat Released/Volume of } \\
\quad \text { Combustion Products (Btu/SCF) }\end{array}$ & $\begin{array}{c}300-310 \\
4.3-5.2 \\
3000-3200 \\
10,100-10,300 \\
95-101 \\
\end{array}$ & $\begin{array}{r}950 \\
1.4 \\
10,600 \\
11,100 \\
90\end{array}$ & $\begin{array}{c}24.00 \\
0.5 \\
10,400 \\
10,800 \\
92\end{array}$ & $\begin{array}{l}3100 \\
n .35 \\
10,400 \\
10,800 \\
92\end{array}$ \\
\hline
\end{tabular}

1. From Yarple, 1974; and Donnegan, 1975.

2. Gas compressed to 35 psig from 1 atm.;-100 F with $75 \%$ efficiency 
Table H-6

Average Slag Analysis

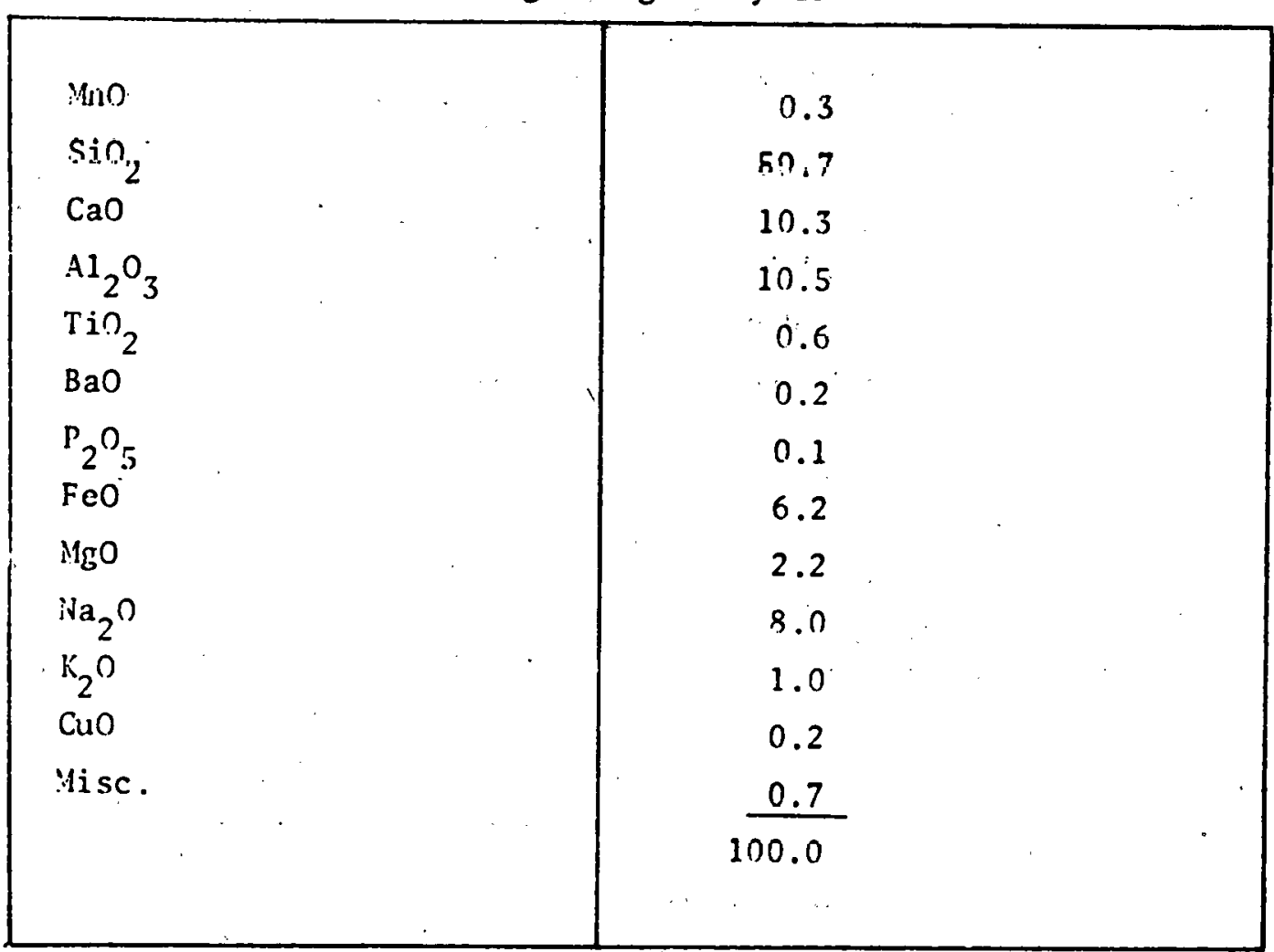

From: Bonnet, 1975 
Detailed.mass and energy balances for the process are contained in Figures $\mathrm{H}-2$ and $\mathrm{H}-3$, respectively. The PUROX process as described in this study does not include conversion of the fuel gas to any other end use fuel. However, processes exist to convert pyrolytic gas to several common products including ammonia and methanol. Figure H-4 shows material and energy flows through a methanol subsystem designed to act as an add-on to the PUROX process. A schematic diagram for such a conversion process is shown in Figure H-5. A summary of the overall PUROX system inputs and outputs is shown in Table $\mathrm{H}-7$.

\section{Landguard System}

The Monsanto Landguard plant installed at Baltimore, Maryland, is a 1000-TPD plant sited on a 10-acre panel and costing a total of $\$ 19$ million. Six million of this total was provided to the city by a Section 208 EPA grant, and \$4 million by the Maryland Environmental Services. The plant has been designed and constructed by Monsanto Enviro-Chem Systems, Inc. Initial construction of the plant was completed in June of 1975 and production testing was begun. Immediate major problems which arose included the inability of the scrubber system to meet state and federal emission standards, premature failure of the kiln refractory, and various mechanical problems. While these problems were basically corrected by mid-1976, new problems caused Monsanto to abandon the project as of January, 1977. The City of Baltimore still plans to operate the plant on a reduced scale (Solid Wastes Management, March 19\%\%.

In defense of the Landguard system it should be noted that two 35TPD test plants (one in St. Louis, Missouri and one in Kobe, Japan) both have met all design specification and emission standards (Sussman, 1974; Hamabe et al., 1975). MSW tested at the Kobe plant was high in both moisture and plastics content. In addition, various industrial wastes and sewage sludge were tested. Both air and water emission standards were met in all tests (Hamabe et al., 1975).

The major inputs to this system in addition to MSW are labor (the Baltimore plant uses 31 employees for $24 \mathrm{hr} /$ day operation), water at a rate of 638 gallons per ton of MSW, electrical energy at a rate of $225 \mathrm{~kW}-\mathrm{hr}$ 


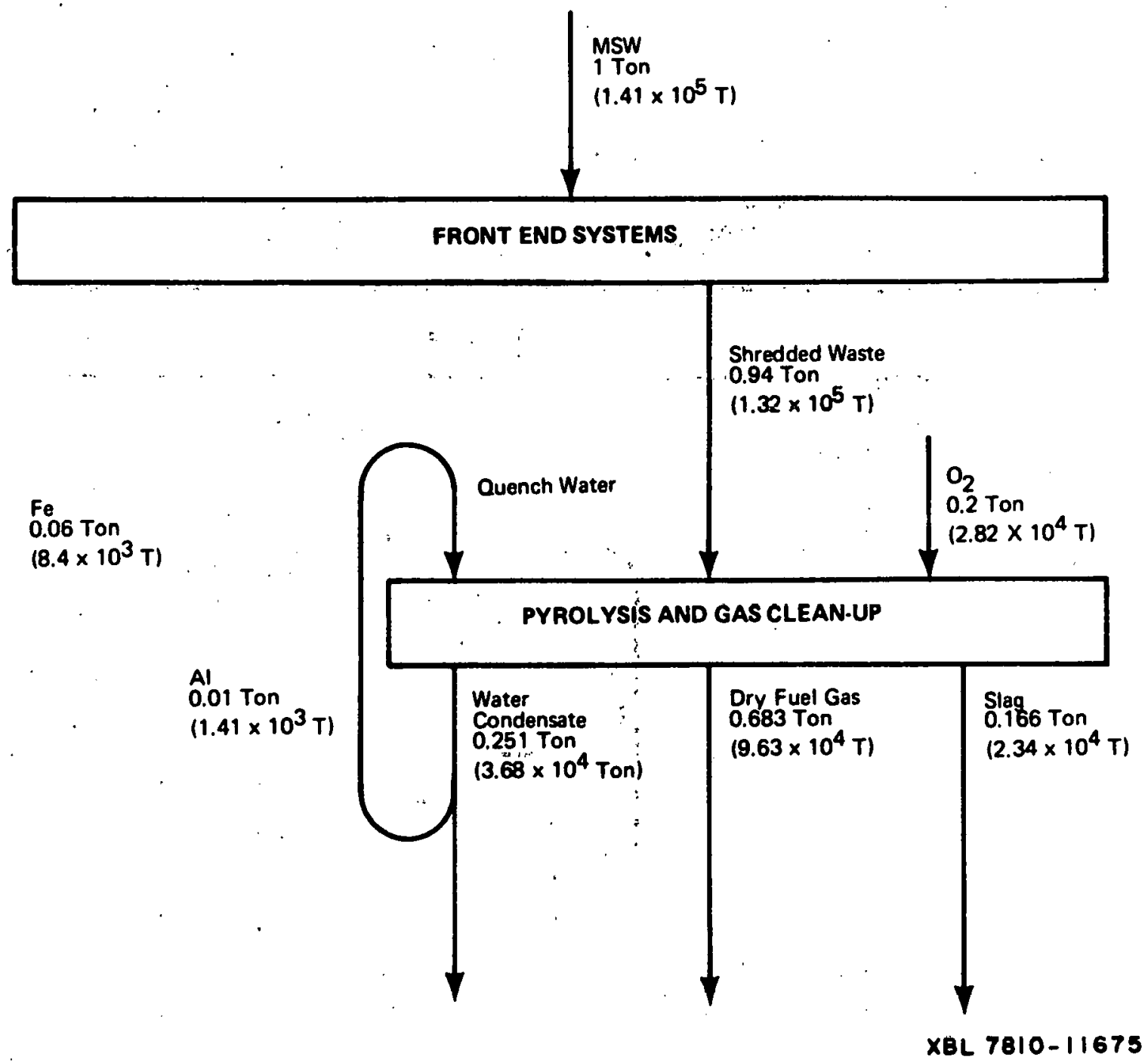

F1g. H-2, PUROX System Material Ralance 


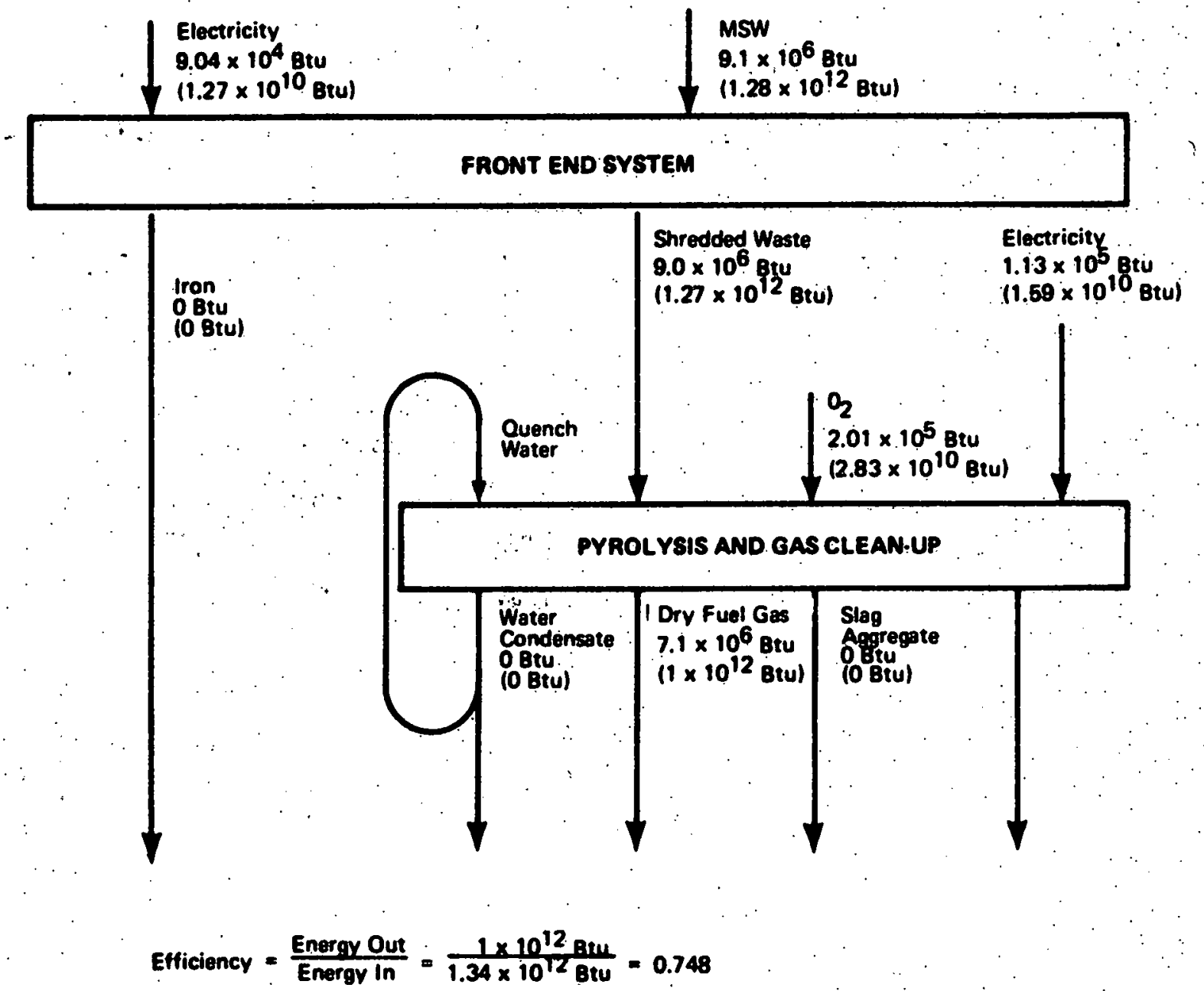

XBL $7810-11676$

Fig. H-3. PUROX System Energy Balance 


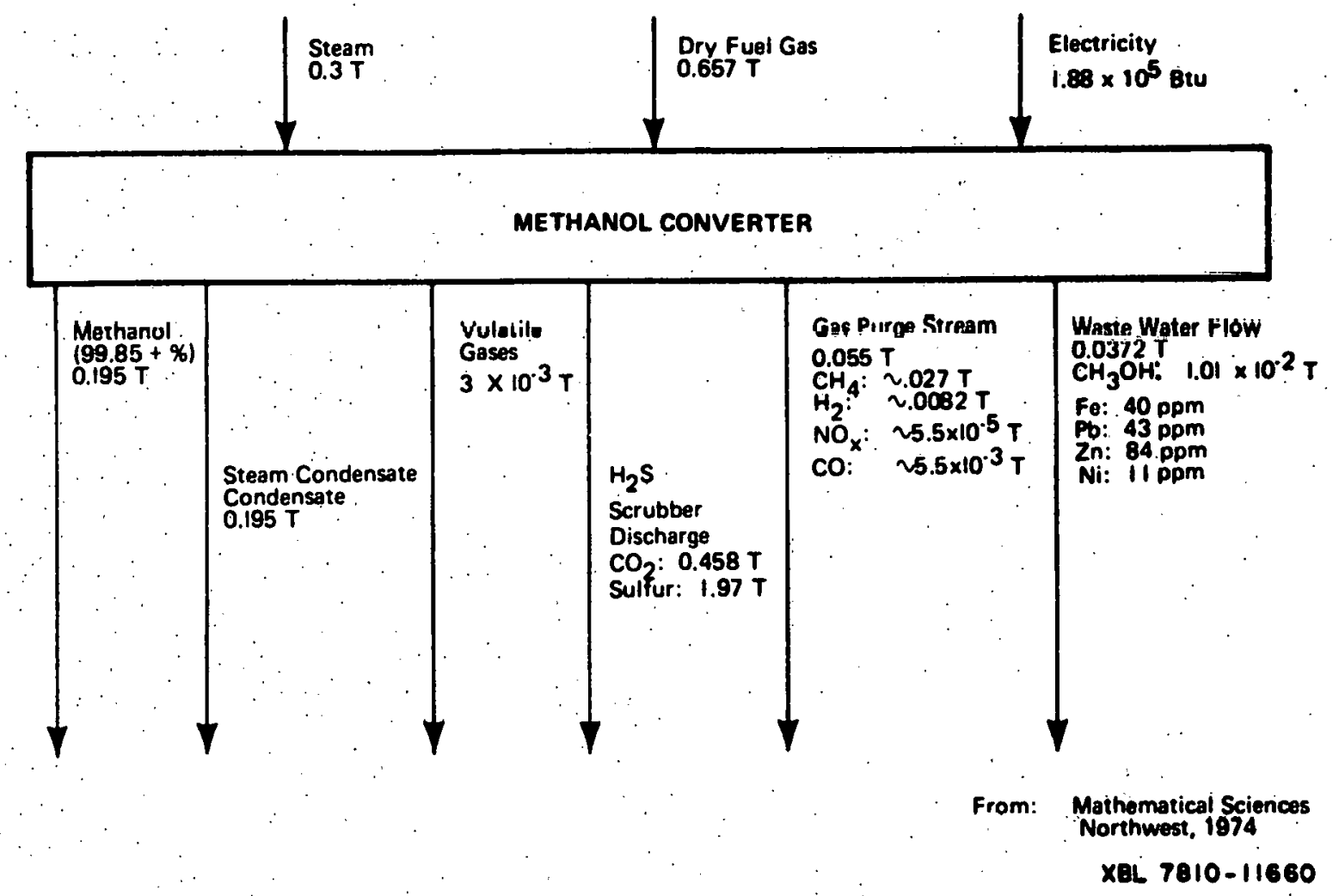

Fig. H-4. Methanol Converter System Input/Output Diagram (per ton of MSW input) 


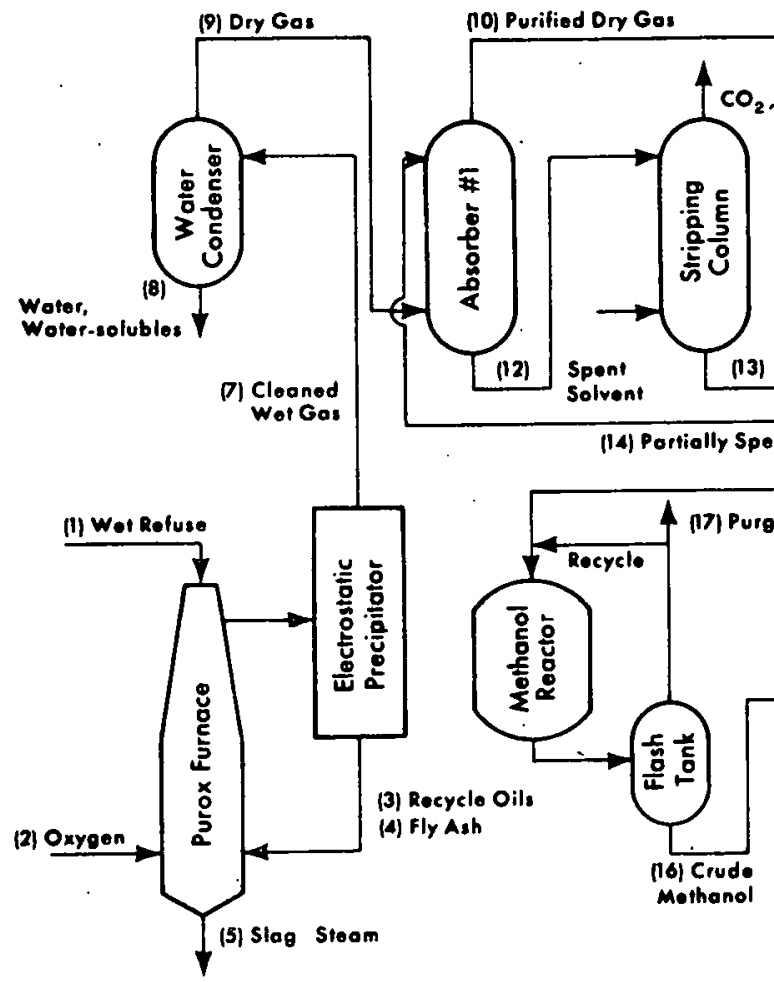

Froms Mathematical Sciences Northwest, 1974

XBL 7810-11652

Fig. H-5. Methanol from Refuse-Flow Diagram 
Table $\mathrm{H}-7$

PUROX Inputs and Outputs per $10^{12}$ Btu Output

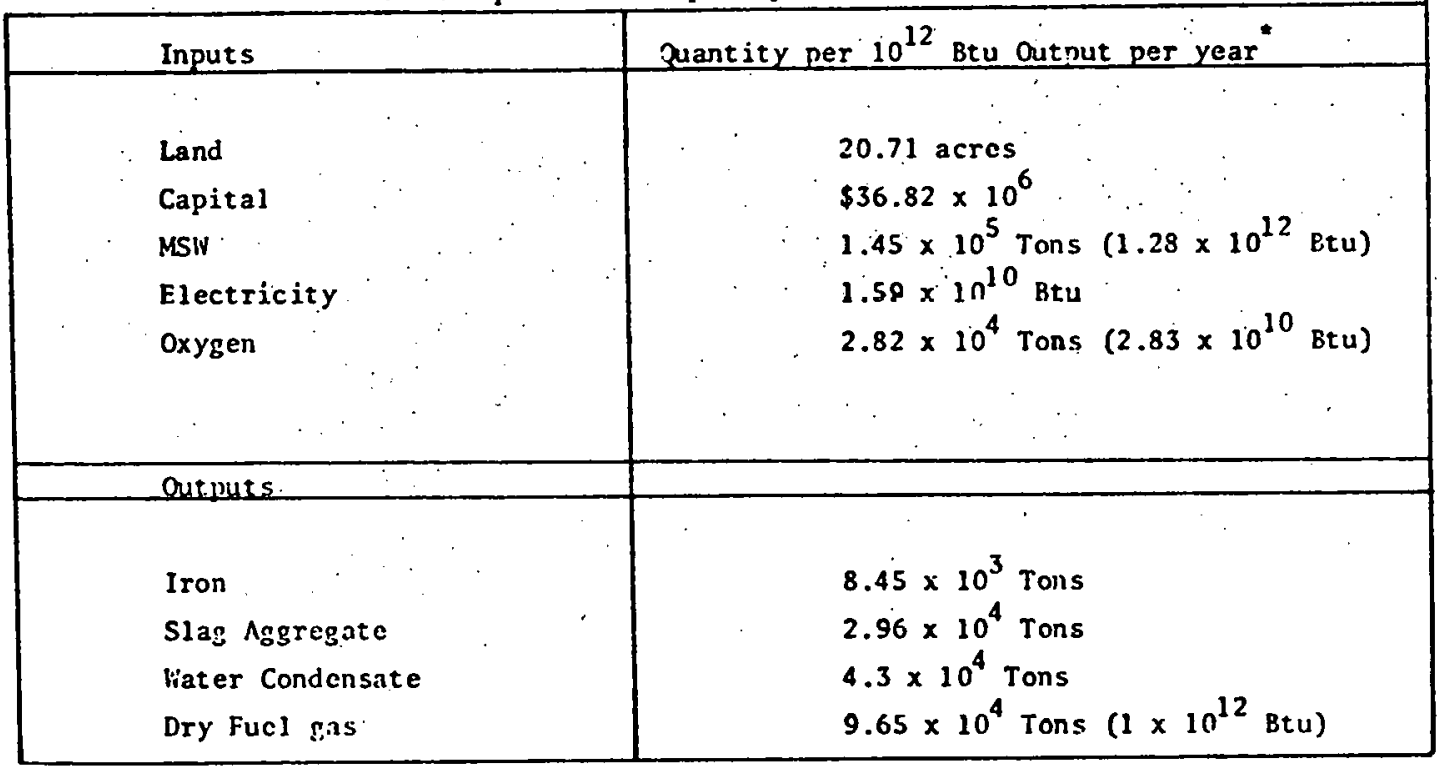

"Capital residual (Land and Capital are calculjuled as in Tablo H-8 based on an annual purox system output of $4.343 \times 10^{11} \mathrm{Btu}$. 
per ton of MSW and miscellaneous oils and liquid fuels at a rate of 7.3 gallons per ton of MSW.

The basic products of the system are steam at a rate of 2.4 tons per ton of MSW, glass, ferrous metals and aluminum for recycling, and a 94percent reduction in the volume of the solid wastes to be land filled (Sussman, 1974; California State Solid Wastes Management Board, 1975). The one intermediate product, pyrolysis gas, is a low Btu gas (approximately $120 \mathrm{Btu} /$ cubic $\mathrm{ft}$ ) and on a dry basis consists of approximately 69.3 percent nitrogen, $11: 4$ percent $\mathrm{CO}_{2}, 6: 5$ percent $\mathrm{CO}, 6.6$ percent hydrogen and minor amounts of methane, ethylene and oxygen (Sussman, 1974). This gas is burned in an afterburner to generate product steam.

As a rotary kiln process, the Landguard system requires only coarse shredding of incoming MSW. This waste is then stored and ram fed directly into the kiln where fuel oil is added to drive the pyrolysis reaction. Char produced in the kiln is quenched and sorted in accordance with the assumed design of the basic resource recovery module. Gasses produced in the kiln are burned to completion in an afterburner at $1400^{\circ} \mathrm{F}$. Gas turbines are not employed in this system. Waste heat is directed into two parallel boilers to generate 200,000 pounds of steam per hour. Waste gasses are scrubbed and are passed through a cooling dehumidifier prior to discharge. Scrubber waste water passes through a settling tank where flocculent is added, with the overflow being recycled to the scrubbers and the underflow being used as quench water for the solid char.

A basic mass balance for this system is shown in Figure H-6. The system energy balance is shown in Figure H-7. Data for these figures were compiled from a joint analysis of work by: Mallan and Titlow, 1975; Sussman, 1974; California State Solid Waste Management Board, 1977 and 1975; Quimby, 1975; Weinstein and Toro, 1976; Malin, 1971; Hamabe et al., 1975; Livingston, 1976; Sessler, 1975; Schnelle and Yamamoto, 1975. Basis efficiency parameters are shown in Figure $\mathrm{H}-8$. Total projected output of a 1000-TPD Languard plant is $1.701 \times 10^{12} \mathrm{Btu}\left(7.34 \times 10^{5}\right.$ tons of steam per year). A summary of the overall system inputs and outputs is shown in Table $\mathrm{H}-8$. 


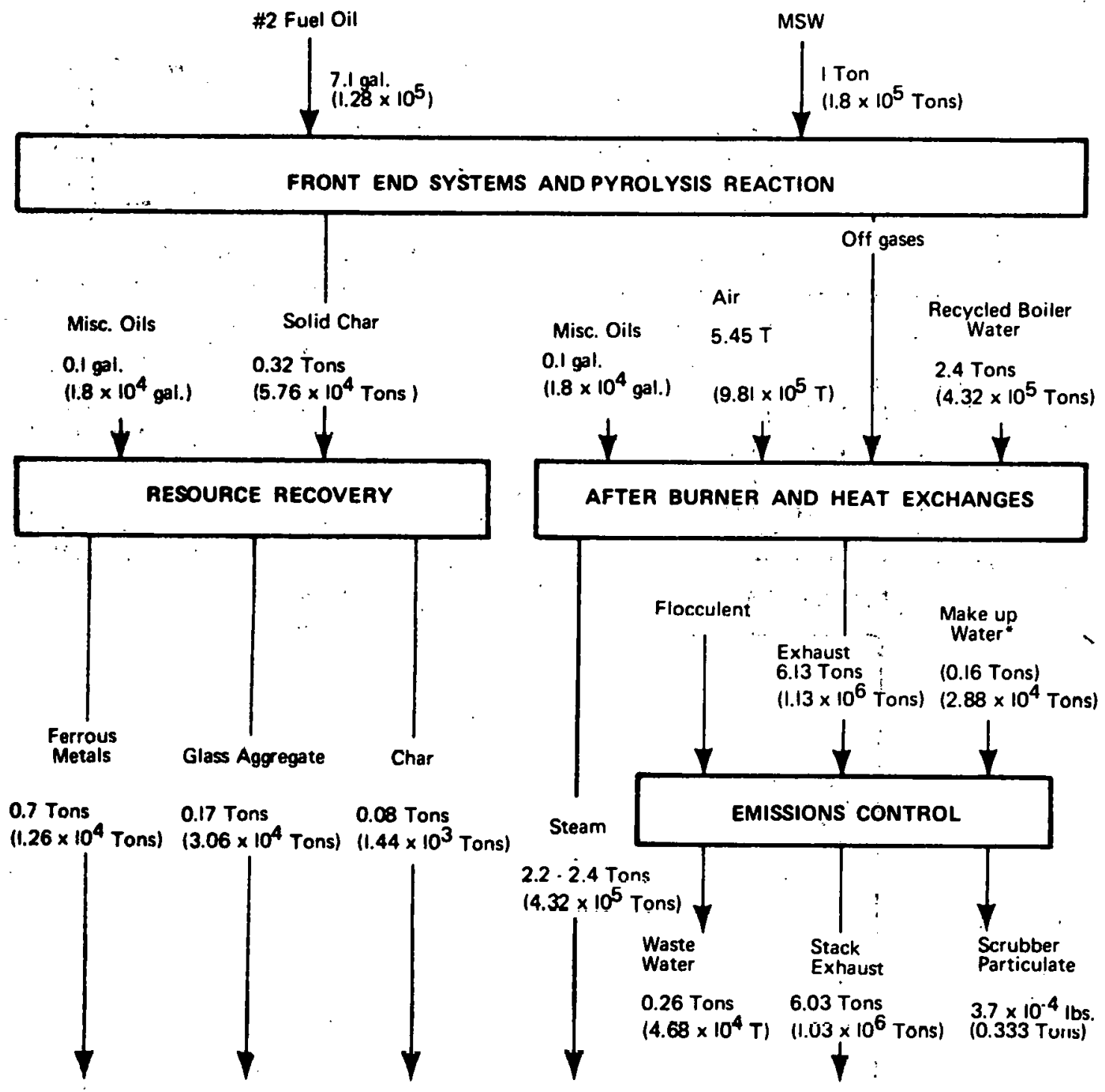

Figure shown as amount per ton of MSW input and (amount per $10^{12}$ Btu of steam output)

- Water makeup assigned to emission control module; however, some of this water is used in char waterquench.

XBL $7810-11661$

Fig. H-6. Landguard Pyrolysis System Mass Balance 


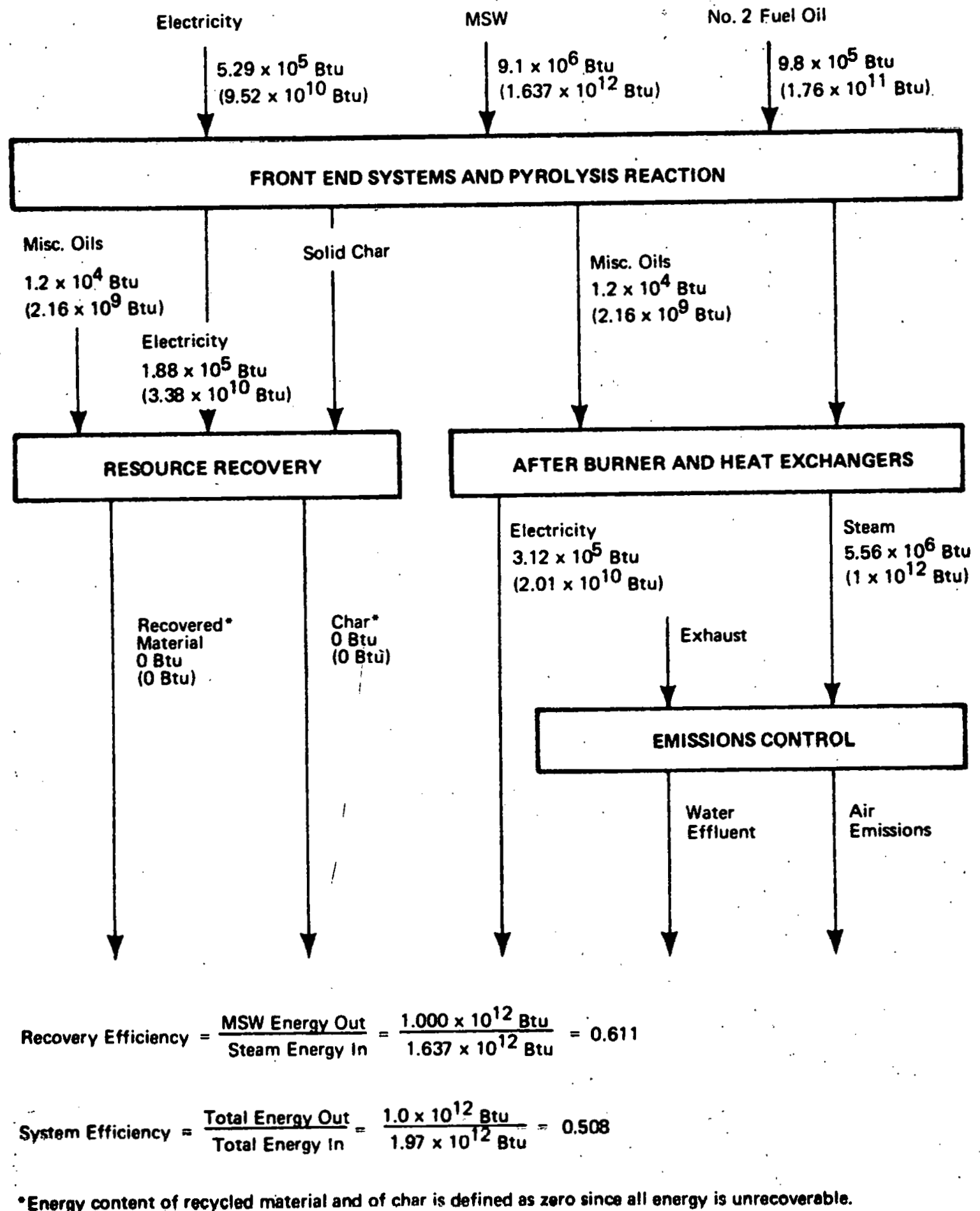

XEL $7810-11666$

Fig. H-7. Landguard Pyrolysis System Energy Balance 
Table H-8

Landguard System Input/Output Summary

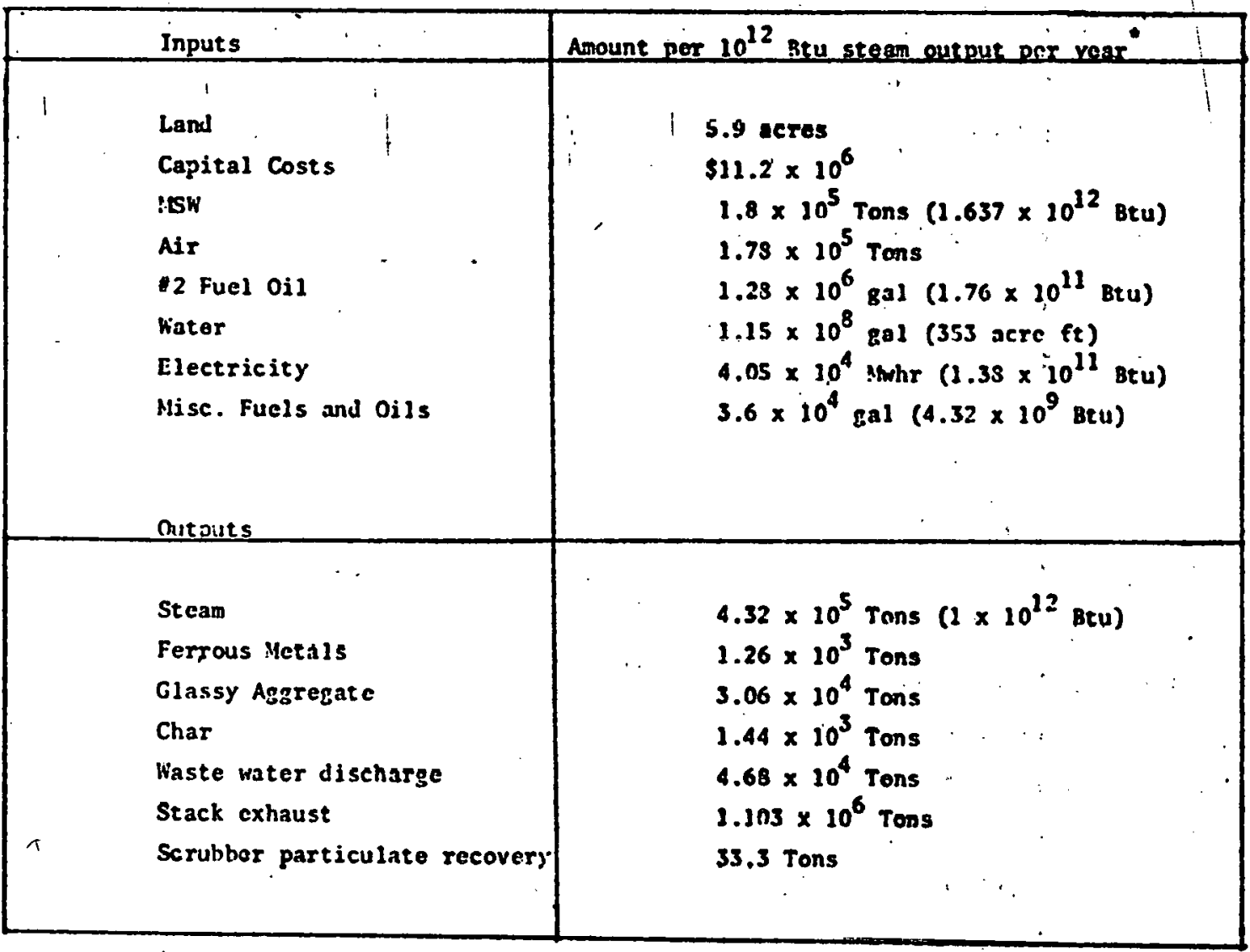

"For capital resources figures given as input per $10^{12}$ Btu annual output. Thus if plant output $=2 \times 10^{12}$ Btu annual cutput $=$ total required input divided by $?$. 
Effluent flows for the Landguard system are summarized in Table H-9. Table $\mathrm{H}-10$ summarizes mean residual generation rates per $10^{12}$ Btu of steam output. SEAS input forms for residuals are contained in the Appendix to this report. Waterborne effluent flows are less than $75 \mathrm{gpm}$. To date no data on residual concentration are available. However, this pollutant flow is though to be relatively free of particulate BOD and COD concentrations.

Projected system operating economics are shown in Table H-11. Greater detail on capital and operating input is contained in the Capital Requirements section of this report.

\section{Garrett Flash Pyrolysis}

The Garrett flash pyrolysis system differs from the previous two systems in that it is an oil-producing system. It also has the most extensive front end system of the three pyrolysis plants described in this report. This plant uses a low temperature $\left(900^{\circ} \mathrm{F}-1300^{\circ} \mathrm{F}\right)$ flash pyrolysis to produce the product mix described in Table H-12. As described, this pyrolytic oil is a direct substitute for Bunker C oil (Preston, 1976). The flash pyrolysis process was developed privately by the Garrett Research Corporation on a 4 TPD test plant. Following successful testing of that system, a 200-TPD prototype was completed in 1976 for San Diego County under partial funding by U.S. Environmental Protection Agency and by San Diego Gas and Electric Company at a total cost of between $\$ 18$ and $\$ 20$ million. System tests evaluations and adjustments have been made over the 1976-1978 period, including both MSW tests and tests on various industrial waste streams.

The front end system for this plant includes resource recovery of ferrous metals, aluminum and glass as well as both coarse and fine shredding of the organic wastes. The specific flow diagram for this front end process is shown in Figure $\mathrm{H}-8$. While this system provides expanded resource recovery, it does so by incurring a significant capital and operational cost. Estimated capital cost of this expanded front end system is between $\$ 1.5 \mathrm{million}$ and $\$ 2.5 \mathrm{million}$. The added operational cost is primarily an added electrical energy requirement (approximately $40 \mathrm{~kW}-\mathrm{hr} /$ ton of MSW or $1.37 \times 10^{5} \mathrm{Btu} / \mathrm{ton}$ of MSW) and a 
Table H-9

Landguard Stack Effluents per $10^{12}$ Btu. Output

\begin{tabular}{|l|c|}
\hline Pollutant & Residuals per $10^{12}$ Btu System Output \\
\hline${ }^{\text {No }} \mathrm{x}$ & 77.2 Tons \\
$\mathrm{SO}_{2}$ & 127 Tons \\
Particulates & 7.6 Tons \\
IICl & 306 Tons \\
Hydrocarbons & 12 Tons \\
Chlorides & 55.2 Tons \\
\hline
\end{tabular}


Table H-10

Landguard System Stack Residuals

\begin{tabular}{|c|c|c|c|c|c|c|}
\hline \multirow[b]{2}{*}{ Pollutant } & \multicolumn{5}{|c|}{ Source of Estimate } & \multirow[b]{2}{*}{ Mean } \\
\hline & $\begin{array}{c}\text { CA State } \\
\text { Solid Waste } \\
\text { Mgmt. Board } \\
1976\end{array}$ & $\begin{array}{l}\text { Boss, } \\
1974\end{array}$ & $\begin{array}{c}\text { Sussman, } \\
1974\end{array}$ & $\begin{array}{c}\text { Malin, } \\
1971\end{array}$ & $\begin{array}{c}\text { Weinstein } \\
\text { and Toro, } \\
1976\end{array}$ & \\
\hline${ }^{N O} x$ & $100 \mathrm{ppm}$ & & $50 \mathrm{ppm}$ & $50 \mathrm{ppm}$ & $65 \mathrm{ppm}$ & $70 \mathrm{ppm}$ \\
\hline $\mathrm{SO}_{2}$ & $\sim 100 \mathrm{ppm}$ & & & $190 \mathrm{ppm}$ & $100 \mathrm{ppm}$ & $115 \mathrm{ppm}$ \\
\hline Particulates* & $.02 \mathrm{gr} / \mathrm{scf}$ & $.03 \mathrm{gr} / \mathrm{scf}$ & $.03 \mathrm{gr} / \mathrm{scf}$ & $.03 \mathrm{gr} / \mathrm{scf}$ & $.02 \mathrm{gr} / \mathrm{scf}$ & $.03 \mathrm{gr} / \mathrm{scf}$ \\
\hline $\mathrm{HCl}$ & $3.4 \mathrm{lb} /$ ton & & & & & $3.4 \mathrm{lb} / \mathrm{ton}$ \\
\hline Hydrocarbons & & & & & 10 ppm & $10 \mathrm{ppm}$ \\
\hline Chlorides & & & & & $25 \mathrm{ppm}$ & $25 \mathrm{ppm}$ \\
\hline
\end{tabular}

${ }^{*}$ corrected to $12 \% \mathrm{CO}_{2}$ 
Table $\mathrm{H}-1 \mathrm{I}$

\section{Landguard System Economics (\$per ton of MSiN)}

\section{Amortization}

Operating Cost

Material inputs

:Janpower

Maintenance

iliscellaneous
4.00

1.10

1.80

.60
$\$ 5.55$

$\$ 7.60$

$\$ 13.15$

Total Cost

$\$ 7.60$

$:-20$

Revenues

\begin{tabular}{lr} 
Steam & 6.18 \\
Iron & 1.55 \\
Glassy Aggregate & .40 \\
\hline
\end{tabular}

$\$ 8.13$

Net Cust per Ton

$\$ 5.02$

From Cal. State Solid laste lanagement Board, 1975; Sussman, 1974. 
Table H-12

Garrett Flash Pyrolysis Products

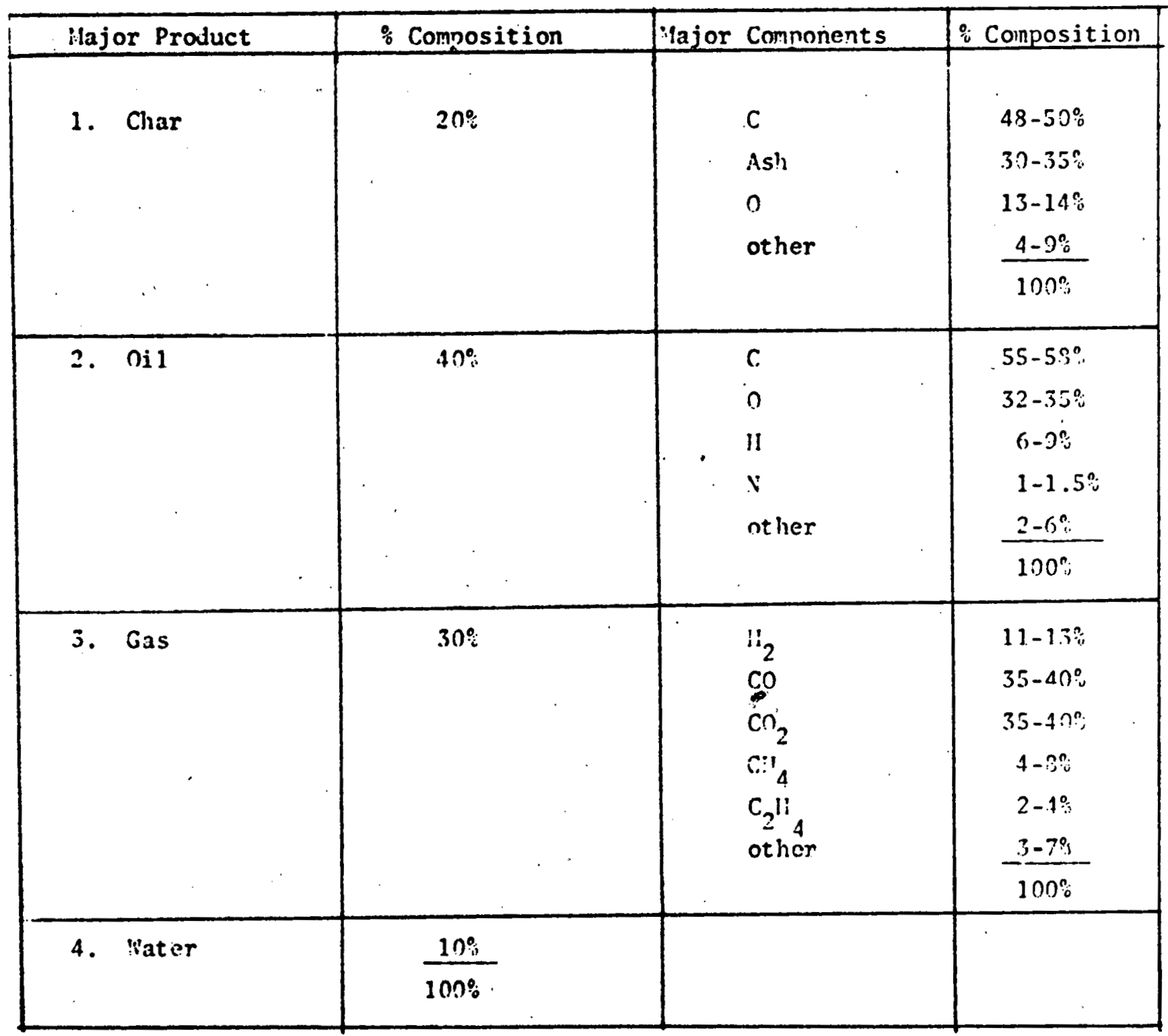

From Preston, 1976; Levy, 1975. 


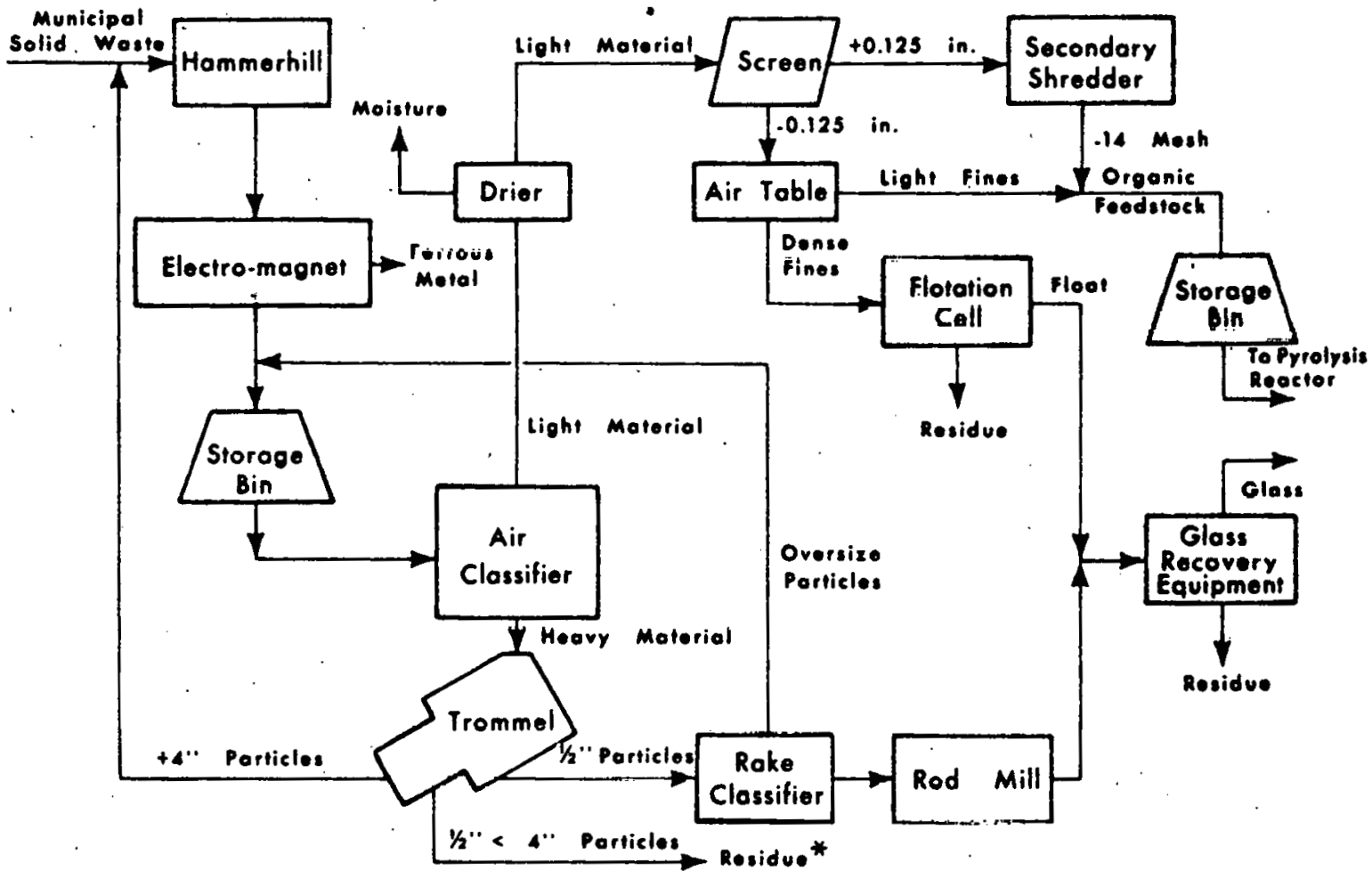

* This would be the nufeedstock to an aluminum recovgey plant.

Fig. H-8. Garrett Flash Pyrolysis Front End System (Levy, 1975) 
an increased maintenance requirement. The majority of the added energy cost is for the required fine shredding process. Figure $H-9$ shows the energy cost associated with this single process.

The pyrolytic gas and most of the char produced in the pyrolytic reaction are recycled into the pyrolytic furnace. This gas is the driving force for the pyrolytic reaction. A mechanical separator and an oil decanter are used to separate the product oil from char and gas, respectively. After gas cleanup, excess process gas is burned in an afterburner; used to preheat recycled gas and char, and exhausted through a baghouse filter.

The major inputs to this process per ton of MSW include approximately 84 gallons of water ( $700 \mathrm{lbs})$, minor amounts (516 units) of No. 2 fuel oil, and $140 \mathrm{~kW}$-hr of electricity. Major products include approximately 41 gallons of oil ( 338 lbs at $12,390 \mathrm{Btu} / \mathrm{lb}$ ), 106 pounds of glass aggregate, 165 pounds of ferrous metal, 13.5 pounds of aluminum, 315 pounds of inert material, 500 pounds of waste vapor, 121 pounds of process waste water, and 111 pounds of char. A 200-TPD plant produces $4.188 \times 10^{6}$ Btu of oil per ton of MSW for an annual average production of $2.56 \times 10^{11}$ Btu.

The Garrett flash pyrolysis material balance is shown in Figure $\mathrm{H}-10$. The system energy balance is shown in Figure H-12. Data for Figures $H-10$ and $\mathrm{H}-1 \mathrm{l}$ were obtained from.a critical synthesis of data contained in: Preston, 1975 and 1976; Levy, 1974 and 1975; Garbe, 1976; Weinstein and Toro, 1976:- International Research and Technology Corporation, 1972; Schnelle and Yamamoto, 1975; and Mallan and Titlow, 1976. Overall energy efficiency of this system as shown in Figure $\mathrm{H}-11$ is 43.3 percent. Major system inputs and vutputs are summarized in Table $\mathrm{H}-13$.

Residuals generated by the Garrett process are listed by stream in. Table H-14. As can be seen, 100x emissions and COD load in the process waste water stemming from a series of oils and tars formed with, and existing with, the water in the pyrolytic reaction, form major environmental problems for this system.

System econumics are listed in the Capital Residual section of this report. 


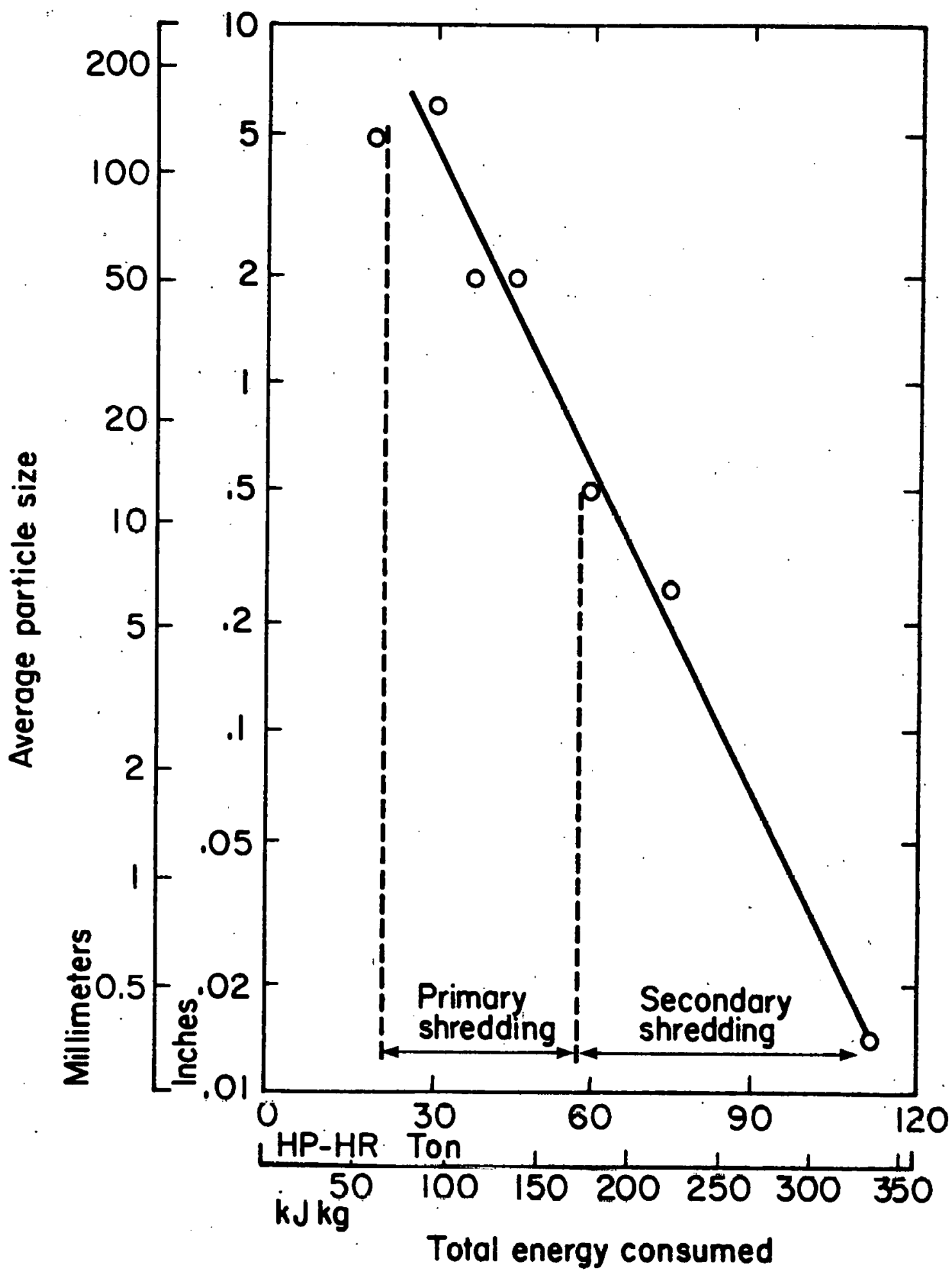

XBL $7810-11670$

Fig. H-9. Energy Consumption for Primary and Secondary Shredding (Preston, 1976) 


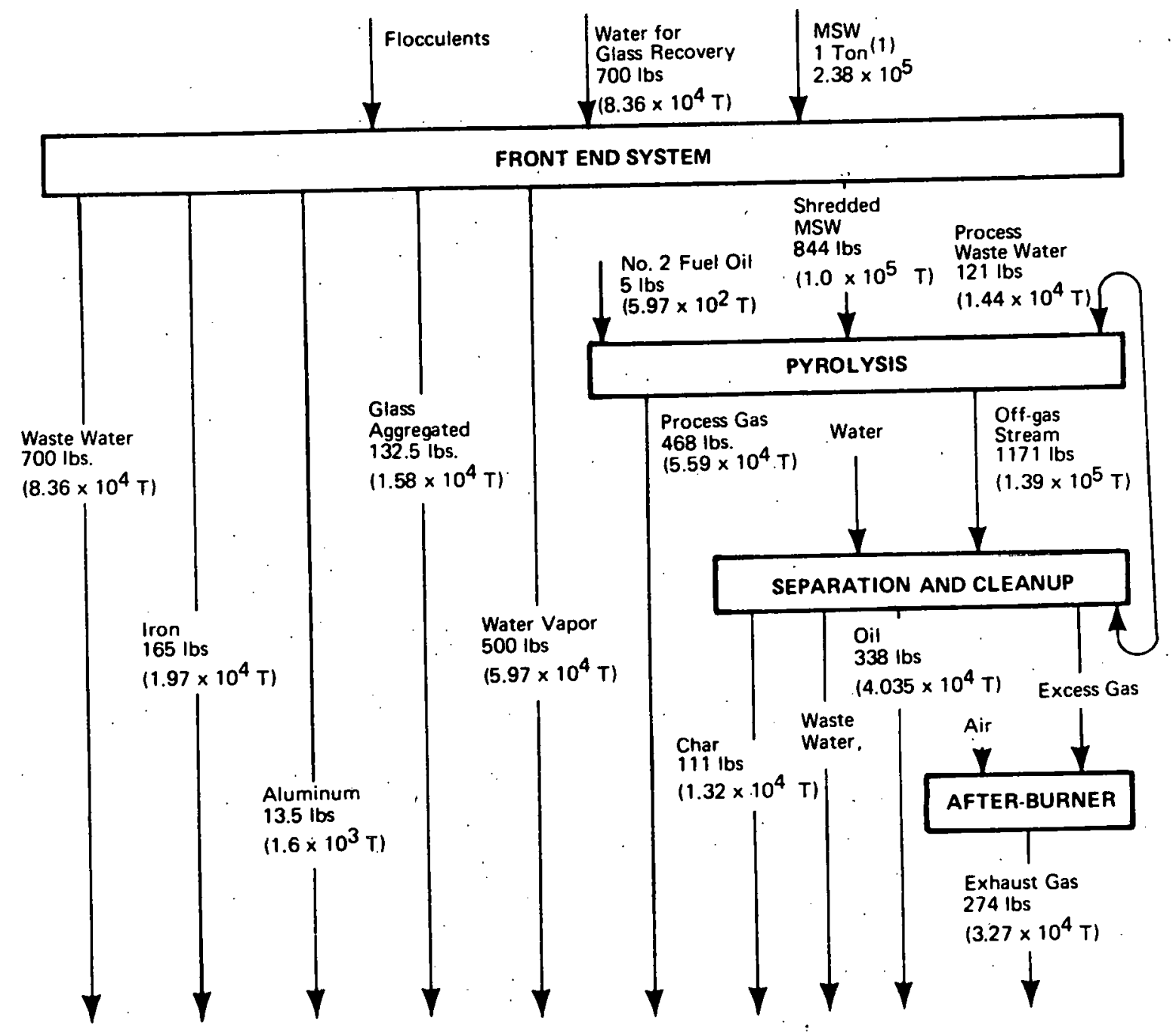

(1) Data shown on a per ton of MSW and a (per $10^{12}$ Btu output basis.

XBL 7810-11665

Fig. H-10. Garrett System Material Balance 


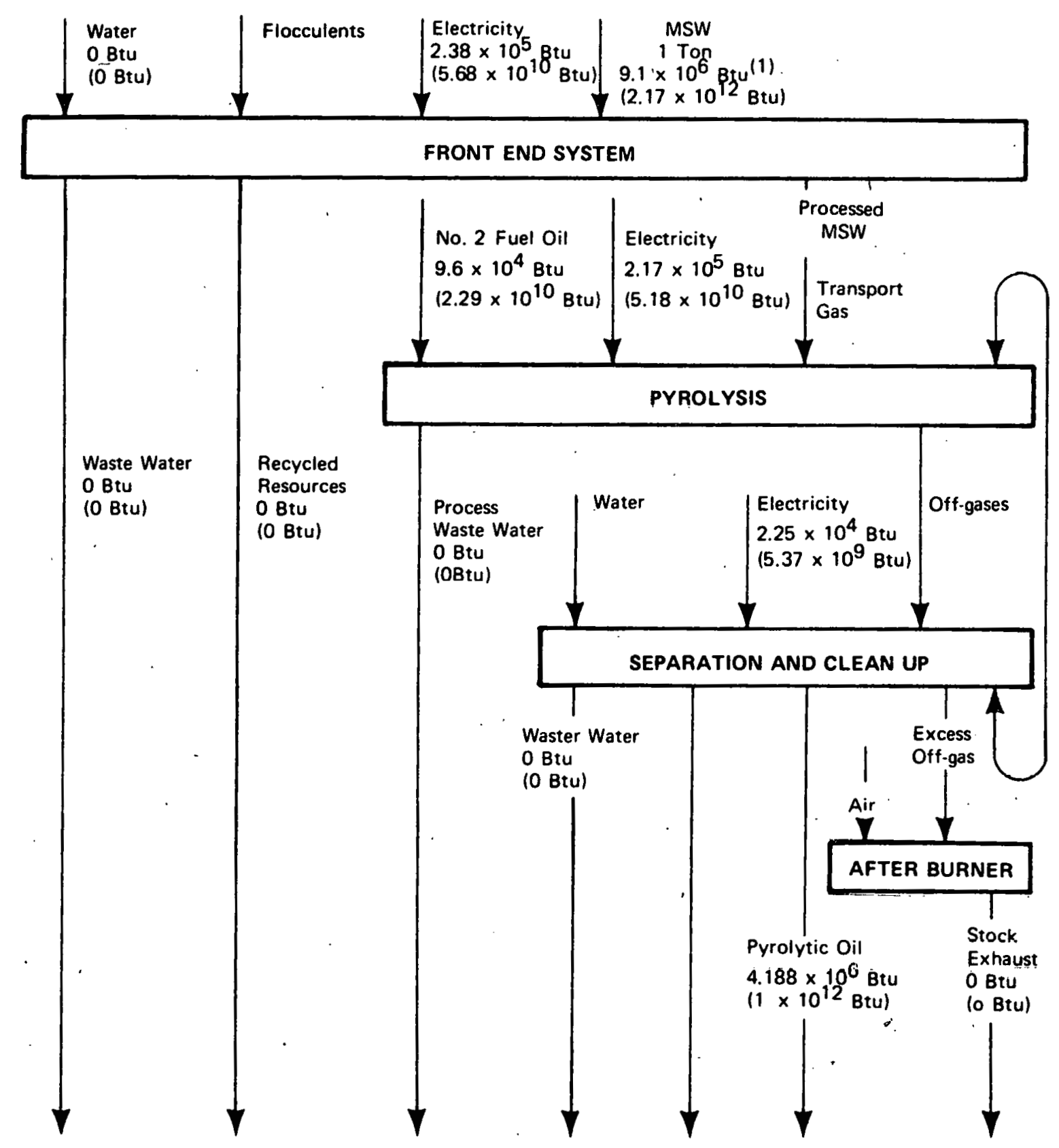

(1) Numbers describe amount per ton of MSW and amount per $10^{12}$ Btu output.

XBL $7810-11662$

Fig. H-11. Garrett Process Energy Balance 
Table H-13

Sumnary of Major Inputs and Outputs for the Garrett Flash Pyrolysis Process

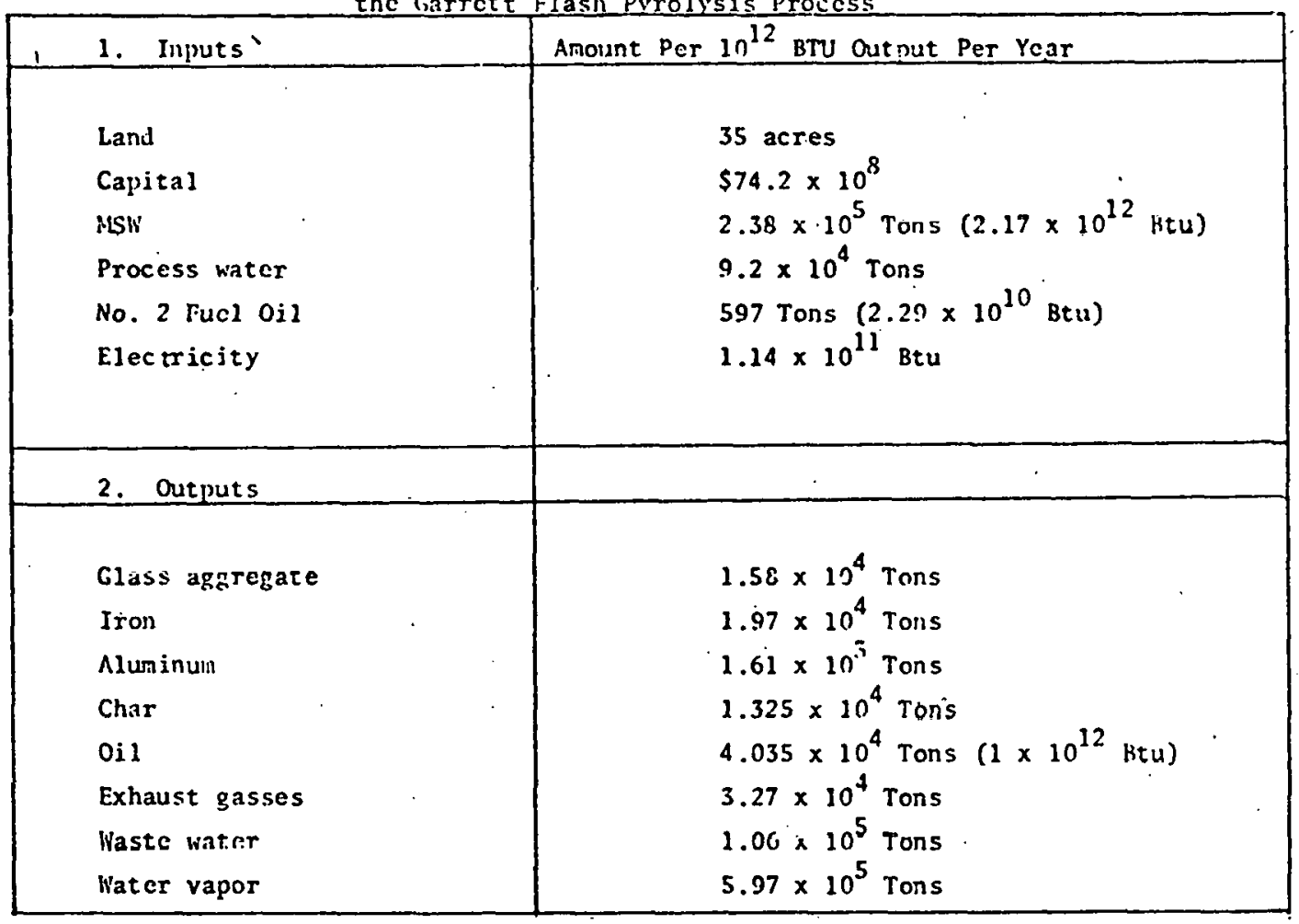


Table $\mathrm{H}-14$

Garrett Process Residuals

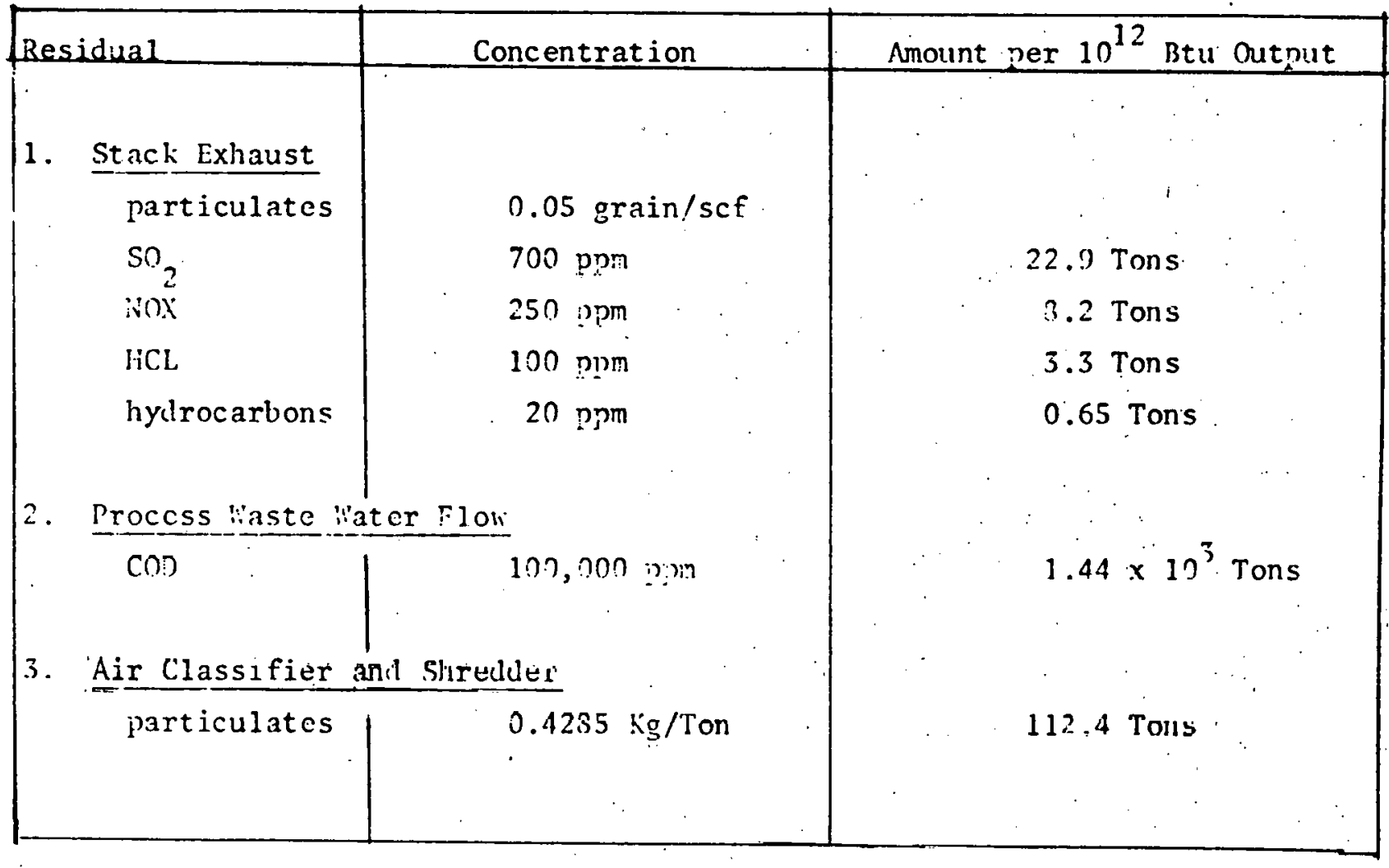

From Levy, 1975; Preston, 1976; International Research and Technology Corn., 1972; and Sessler and Cilkor, 1975. 


\section{REFERENCES: APPENDIX H}

Anderson, J.E., "The Oxygen Refuse Converter-A System for Producing Fue1 Gas, Oil, Molten Metal and Slag from Refuse," in Resource Recovery Through Incineration, Proceedings of the 1974 National Incineration Conference, 1974.

Bonnert, F.W., Partial Oxidation of Refuse using the PUROX system, Union Carbide Corp.. unpublished, 1975.

California State Solid Waste Management Board, Current Status of Resource Recovery Systems and Processes, Technical Information Series Bulletin No. $5,1975$.

California State Solid Waste Management Board, Refuse to Energy Conversion Projects, December 1977.

Donnegan, T.A., Union Carbide PUROX System for Solid Waste Disposal and Resource Recovery, 1975.

Donnegan, T.A., "Union Carbide PUROX System for Solid Waste Disposal and Resource Recovery," Energy from Solid Waste Utilization, Proceedings of the Sixth Annual Northeastern Regional Anti-Pollution Conference, $1975 a$.

Fisher, T.F., M.L. Kasbohm and J.R. Rivera, "The 'PUROX' System," Paper presented at the AIChE 80th National Meeting, 1975.

Garbe, Y.M., "Demonstration of Pyrolysis and Materials Recovery in San Diego, California," Waste Age, December 1976.

Hamabe, I., T. Tsugeno and S. Nozu, "Pyrolyzing Test of Municipal Wastes in Japan," in Conversion of Refuse to Energy, Institute of Electrical and Electronic Engineers, Inc, Piscataway, NJ, 1975.

International Research and Technology Corporation, Problems and Opportunities in Management of Combustible Solid Wastes, 1972.

Levy, S.J., San Diego County Demonstration of Pyrolysis Solid Waste, 1975 .

Levy, S.J., "Pyrolysis of Municipal Solid Waste," Waste Age, Volume 5, Number 7, 1974.

Livingston, R.A., "Energy from Solid Waste," Environmental Aspects of Non-Conventional Energy Sources, Transaction of ANS Meeting, 29 February - 3 March, 1976.

Malin, H.H., "Pyrolysis of Refuse Gains Ground," Environmental Science and Technology, $\underline{5}$ (4), April 1971.

Mallan, G.M. and E.I. Titlow, "Energy and Resource Recovery from Solid Wastes," in (S.M. Barnett et al., editors) Energy from Solid Waste Utilization, Proceedings of the Sixth Annual Northeastern Regional Anti-Pollution Conference, 1976.

Marple, D.D., "Energy Recovery from Mixed Municipal Refuse-The Purox System," in (D.E. Earley et al., editors) Energy and the Environment Proceedings of the Second National Conference, 1974. 
Mathematical Sciences Northwest, Inc., Feasibility Study-Conversion of Solid Waste to Methanol or Ammonia, 1974

McFarland, J.M., et al., Comprehensive Studies of Solid Wastes Management, University of California Sanitary Engineering Research laloratory, SERL Report 72-3, 1972.

Preston,.G.T., "Resource Recovery and Flash Pryolysis of Municipal Refuse," Paper presented to the Institute of Gas Technology Symposium on Clean Fuels from Biomass, Sewage, Urban Refuse and Agricultural Wastes, 1975.

Preston, G.T., "Resource Recovery and Flash Pyrolysis of Municipal Refuse," Waste Age, May 1976.

Scharner, C.C., Testimony on the Purox System of Energy Conversion, Presented to the nversight Hearings on the State Solid Wastc Management Board by the California Legislative Assembly Committee on Resources, Land Use and Energy, December 1976.

Schnelle, J.F. and J.H. Yamamoto, "Potential Alternative Fuel Derivatives from Municipal Solid Waste," in (S.M. Barnett et al., editors), Energy from Solid Waste Utilization, Proceedings of the Sixth Annual Northeastern Regional Anti-Pollution Conference, 1975.

Schulz, H.W., "Energy from Municipal Refuse: A Comparison of Ten Processes," Professional Engineer, November 1975.

Schulz, H.W., "Assessmentof Purox Pilot Plant Performance (Task 9)," in A Pollution-Free System for the Economic Utilization of Municipal Solid Waste, 1975a.

Sessler, G. and P.M. Cukor, Pollutant Releases, Resource Requirements, Costs and Efficiencies of Selected New Energy Technologies, Teknekron, Inc., 1975.

Sussman, D.B., Baltimore Demonstrates Gas Pyrolysis - The Energy Recuvery Solid Waste Facility in-Baltimore, Maryland, 1974.

Union Carbide Corporation, Slide Summary and Informal Narrative of a Purox Co-Disposal Program, 1977.

Weinstein, N.J. and R.F. Toro, Thermal Processing of Municipal Solid Waste for Resource and Energy Recovery, Ann Arbor, MI: Ann Arbor Sciences Publisher, 1976. 
APPENDIX I

CAPITAL REQUIREMENTS

\section{INTRODUCTION}

This appendix provides background information for the capital costs associated with the technologies listed in Appendix $A$ in the DOE-prescribed format for direct use in the SEAS model.

For each major technology and application, a single plant type is described. Associated with each plant is a specific plant design and plant capacity. The use of a single plant design and material specification to represent a technology as is done in SEAS implies both linearity betwéen plant size (or output) and all major plant inputs, and an independence of plant cost from specific plant design. While the basic SEAS model structure necessitates these assumptions, it is evident that neither is correct and that significant economies of scale can be realized for several technologies. Figure I-I shows basic unit cost for direct MSW combustion steam recovery system (cost per unit throughput) as a function of plant size. It is evident from this figure that costs for a 1000-TPD plant should not be linearly translated into costs for a $6000-$ TPD plant or for a 30 -TPD plant. Similarly, Figure I-2 shows the non-linear relationship between operational employment requirements for MSW conversion plants and plant size. The use of "average" and mid-range cost figures in this report should minimize the error induced by subsequent linear scaling of plant size and costs by the SEAS model, but will certainly not eliminate the error.

In addition several standard conventions were used to estimate several of the figures listed in Appendix A for capital and operational costs. These conventions are:

- GNP fixed-weighted price indices are used to deflate all data to 1972 dollars.

- 1977 average labor wage rate of $\$ 13.00$ per hour is used for all labor. Previous year's wage rates are obtained by deflating this rate to other year dollars. 


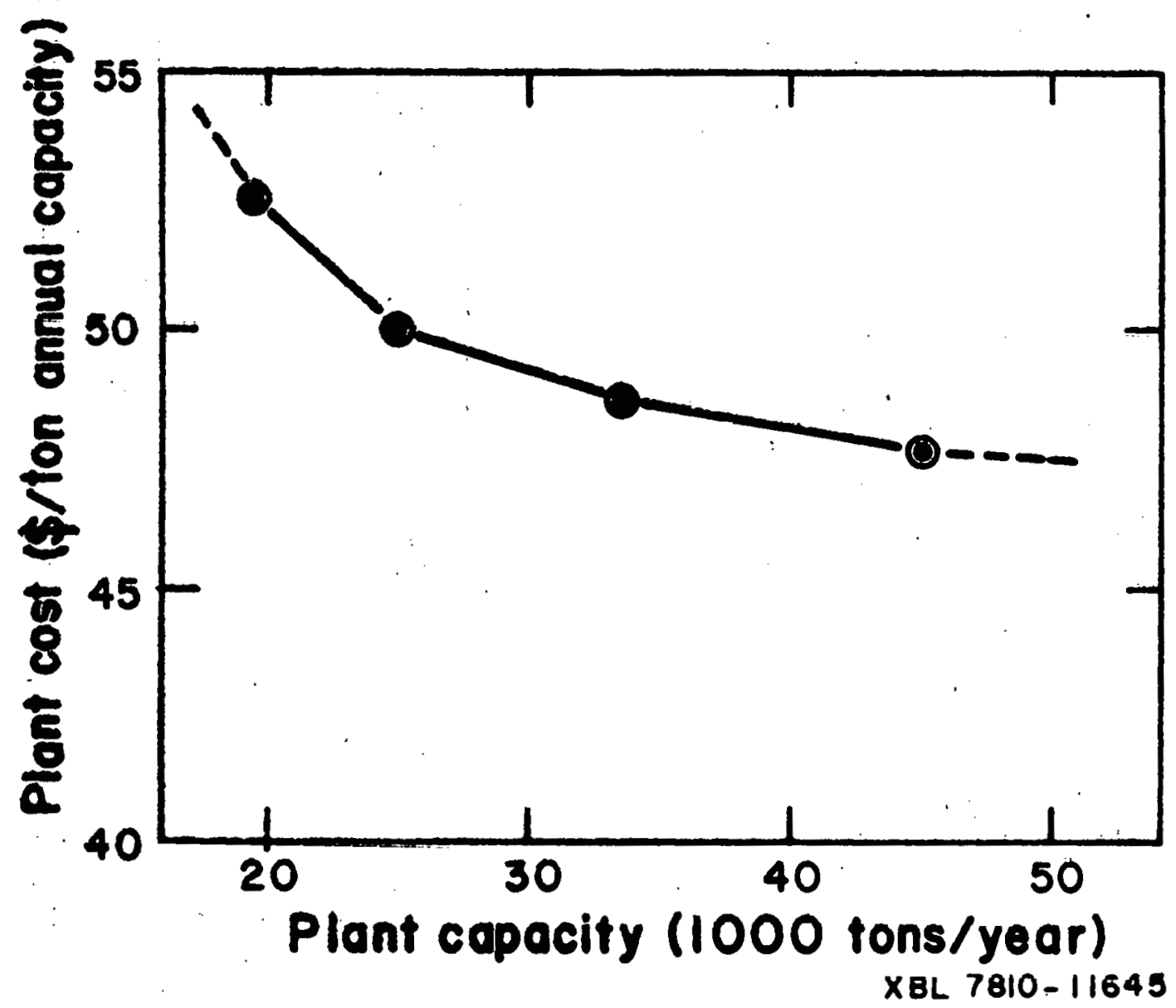

Fig. I-1. Plant Capital Cost as a Function of Plant Size 


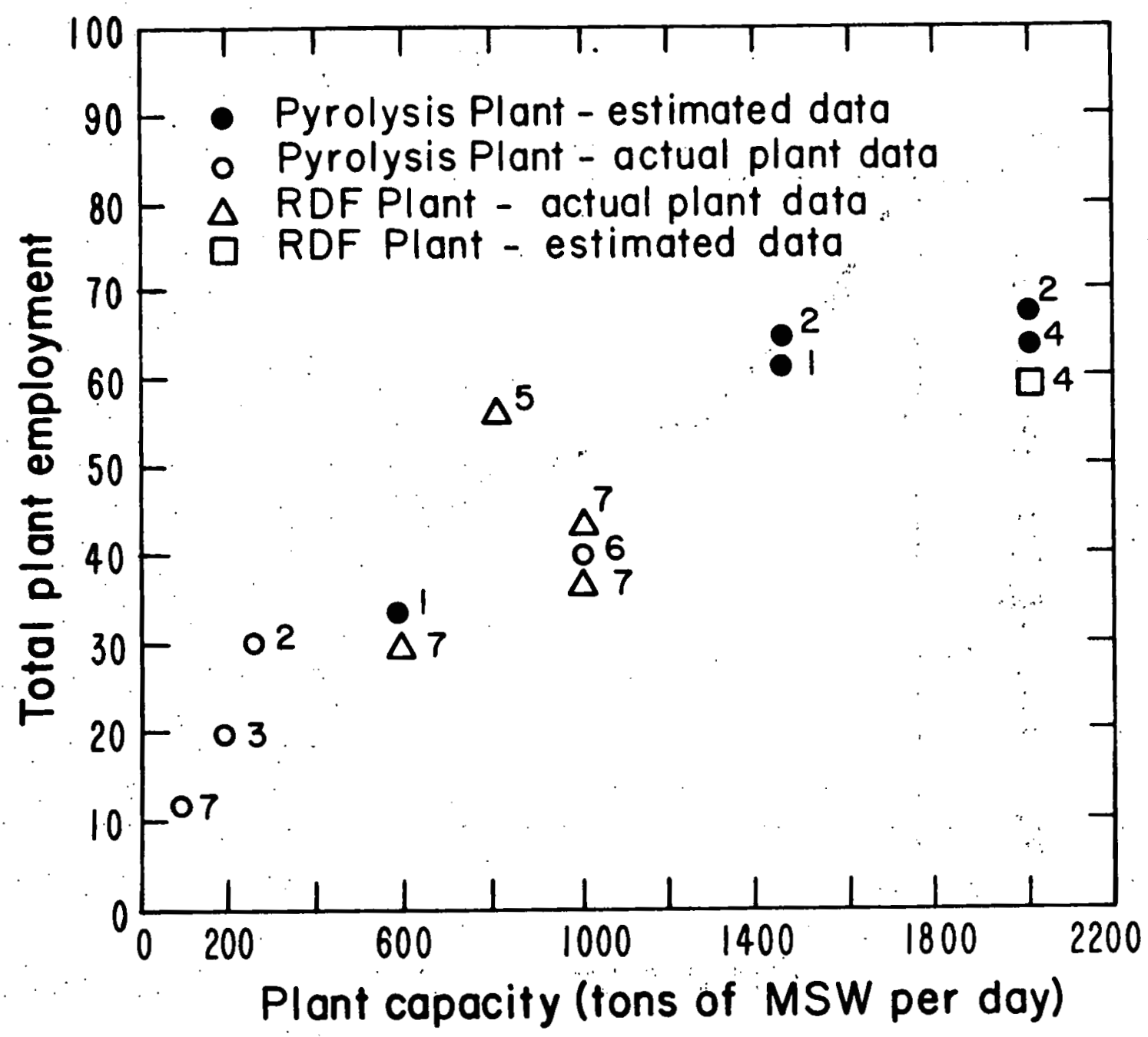

XBL 7810-11644

1. Mathematical Sciences Northwest, Inc., 1974

2. Sathaye, J. et al., 1977

3. Levy, 1975

4. Mallan and Titlow, 1975

5. Klumb, 1976

6. California State Solid Waste Management Board, 1975

7. Generál Electric Corporation, 1975

Fig. I-2. Employment Requirements for Various Site Plants 
- Overhead on labor costs for construction is assumed to be 30 percent of labor while administrative overhead is assumed to be 10 percent of labor costs. Profit assumed to be 10 percent of total project costs.

- One man-year of labor is assumed equal to 2000 hours.

- In the absence of actual transportation cost estimates, transportation costs (SEAS Sector 169 - Trucking) is assumed equal to 8 percent of actual materials costs.

Cost data for a "typical" plant for each of the following technologies are included in Appendix A: pyrolysis of MSW to electrical energy, generation of RDF from MSW with conversion to electricity, enhanced oil recovery converted to electrical energy, fluidized bed system for the pulp and paper industry, and a diesel system for cogeneration. A brief characterization of each plant for which data is listed in Appendix $\mathrm{A}$ is included here so as to document the plant configurations being described.

\section{DIRECT COMBUSTION}

The direct combustion systell thatacterizcd hcro is based on typical or average data compiled from a large number of municipal furnaces. Not all of these furnases are used for energy recovery. Data are based on a 1000-TPV system. Ferruus metal, alunillum and glass aggregote recovery systems have been added for labor, capital and ancillary energy requirements. Waterwall boilers are used to produce steam which acts as the primary system product. Recovered resources are sold to local manufacturing markets. Steam is sellable to a variety of manufacturing processes and to electric utilities for electricity.

RDF

A MSW to RDF conversion plant capable of processing approximately 1500 TPD of MSW and a 350-MWe electric power plant using 20 percent RDF and 80 percent coal are included in the capital residual descriptions. The RDF plant design is patterned after Union Electric's 
St. Louis RDF plant. Power plant sizing and design are typical of the current generation of intermediate-size plants ( $<1000 \mathrm{MWe})$. Electrostatic precipitators are included as an integral element of plant design. RDF products may either be used for electrical generation (as used here) or to support industrial steam production.

PYROLYSIS

The pyrolysis plant described in this report includes both the pyrolysis plants or oxygen production plants and a combined cycle power plant to support a $400^{\circ}-\mathrm{MWe}$ generating capacity. In order to feed the combined cycle with 100 percent pyrolytic gas, 6000-TPD capacity of gas pyrolysis plants are included. These plants are patterned after Union Carbide projections for a 2000-TPD plant páralleling their successful 200-TPD PUROX plant at Charleston West Virginia. Scrubbers and electrostatic percipitators are included as an integral part of the basic plant configuration. Linear scaleup factors are assumed. Gas could support industrial (manufacturing) steam production as an alternate to electricity production. In case final conversion efficiencies are significantly improved (from 32 percent to 80 percent), residuals per $10^{12}$ Btu output should be adjusted downward by a factor of 2.5.

\section{FLUIDIZED BED}

System capital requirement data were derived from Comparative Study and Evaluation of Advanced Cycle Systems by the General Electric Company for the Electric Power Research Institute in February 1978. This work reported a detailed engineering design study on the use of fluidized bed boilers for a utility power plant. That application required 24 FPC cells arranged in six modules. A large number of cells is required due to the small output of fluidized bed boilor 3 . For the pulp and paper cogeneration application considered here, two cells are used in a single module: Each of these cells are scaled to one-third the size of the fluidized beds proposed for utility use. A reduction scale factor of 37 percent is used to account for reductions in module size and number. This scale factor 
is based on staff judgement but is not supported by industry or other estimates.

\section{ENHANCED OIL RECOVERY}

The data for this project are projected from the proposed application in the Kern River 0il Fields which are expected to produce 280 MWe continuous and $1500 \mathrm{bbl} / \mathrm{day}$ of oil, half of which will go directly to market. The other half is used as input to the cogeneration system. Data on the gas turbine are from the Bechtel Energy Supply Planning Model. Data on the heat recovery steam generator are from the Westinghouse Energy Conversion Alternatives Study, Volume 5 . In each case linear scaling factors were used to match component size to oil field output. Cogeneration system products include both steam and electricity. Steam output is designed to support manufacturing industrial process heat requirements. Electricity can either be used internally within the oil field operations.

\section{DIESEL}

The diesel system described here is the most simple of the cogeneration systems included in the study. The system includes only the engine, piping interconnects and transmission intcrconnects. The applicotinn selected is for a municipal sewage disposal plant. Primary engine input fuel for this application is methane derived from municipal sewage sludge and design output capacity is a combined product of 12.6 MWe and $33.8 \times 10^{6}$ Btu of steam per hour. Capital residuals and operational residuals are taken from data developed by the Los Angeles Sanitation District and by Williams and Lane, Inc. Operational material input and labor requirements are not available at this time.

\section{FOSSIL FUEL EQUIVALENCY}

It is essential that the amount of fossil fuel which would be required to produce the amount of end use energy generated by each energy recovery system were the listed fuel (e.p. (MSW) not available, be calculated for use in the SEAS moriel system. This amount of 
Table I-1

System Fossil Fuel Equivalency

\begin{tabular}{|c|c|c|c|c|}
\hline System & Product & Output & $\begin{array}{l}\text { Efficiency } \\
\quad(\xi)\end{array}$ & $\begin{array}{c}\text { Fossil Fue1 } \\
\text { Equivalent } \\
\text { Input }\end{array}$ \\
\hline Direct Combustion & steam & $1 \times 10^{12} \mathrm{Btu}$ & 80 & $1.25 \times 10^{12}$ Btu \\
\hline RDF & electricity & $2.10^{11} \mathrm{Btu}^{1}$ & 33 & $6.06 \times 10^{11}$ Btu \\
\hline Pyrolysis (PUROX) & electricity. & $1 \times 10^{12} \mathrm{Btu}$ & 33 & $3.03 \times 10^{12}$ Btu \\
\hline Fluidized Bed & $\begin{array}{c}\text { stean } \\
\text { electricity } \\
\text { Total } \\
\end{array}$ & $\begin{array}{l}5.54 \times 10^{11} \text { Btu } \\
4.46 \times 10^{11} \text { Btu } \\
1 \times 10^{12} \text { Btu }\end{array}$ & $\begin{array}{l}80 \\
34\end{array}$ & $\begin{array}{l}6.93 \times 10^{11} \text { Btu } \\
1.31 \times 10^{12} \text { Btu } \\
2.00 \times 10^{12} \text { Btu }\end{array}$ \\
\hline Diesel & $\begin{array}{c}\text { steam } \\
\text { electricity } \\
\text { Total }\end{array}$ & $\begin{array}{l}4.01 \times 10^{11} \text { Btu } \\
5.99 \times 10^{11} \text { Btu } \\
1 \times 10^{12} \text { Btu }\end{array}$ & $\begin{array}{l}80 \\
34\end{array}$ & $\begin{array}{l}5.01 \times 10^{11} \text { Btu } \\
1.76 \times 10^{12} \text { Btu } \\
2.26 \times 10^{12} \text { Btu }\end{array}$ \\
\hline Enhanced O11 Recovery & $\begin{array}{c}\text { steam } \\
\text { electricity } \\
\text { Total }\end{array}$ & $\begin{array}{l}2.5 \times 10^{11} \text { Btu } \\
7.5 \times 10^{11} \text { Btu } \\
1 \times 10^{12} \text { Btu }\end{array}$ & $\begin{array}{l}80 \\
34\end{array}$ & $\begin{array}{l}3.13 \times 10^{11} \text { Btu } \\
2.21 \times 10^{12} \text { Btu } \\
2.52 \times 10^{12} \text { Btu }\end{array}$ \\
\hline
\end{tabular}


fossil fuel is the additional amount of fossil fuel which would be consumed if the described solar and conservation systems were not used, and is called the "fossil fuel equivalency" of a system. . Table I-1 shows the fossil fuel equivalency of each of the six systems described in this report. 
REFERENCES

The Aerospace Corporation, Energy Systems, Environmental Control Technology Planning Survey, ATR-76(7518-1), 1975.

The Aerospace Corporation, Energy Recovery from Municipal Solid Wastes, an Environmental and Safety Mini-Overview Survey, AT12-76, 1976.

Anderson, J.E., "The Oxygen Refuse Converter-A System for Producing Fuel Gas, Oil, Molten Metal and Slag from Refuse," in Resource Recovery through Incineration, Proceedings of the $1974 \overline{\text { National }}$ Incineration Conference, 1974 .

Bartolotta, R.J., "Resource Recovery: Possibilities and Pitfal1s," Solid Wastes Management, November 1975, pgs. 52-68.

Bechtel Corporation, Electricity Supply Planning Model, 1977.

Brown, D.H. and R. Corman. Energy Conversion Alternatives Stuny, G.E. Phase I Final Report, Volume 2 Number 1, Part 1, February 1976.

California State Solid Waste Management Board, Resource Program: Volume II Unabridged Report, 1976.

California State Solid Waste Management Board, Refuse to Energy Conversion Project, Report to the California Legislature, December 1977.

Carotti, A.A. and R.A. Smith, Gaseous Emissions from Muncipal Incinerators, EPA Report No. SW-18C, 1974.

Donnegan, T.A., Union Carbide PUROX System for Solid Waste Disposal and Resource Recovery, 1975.

Donnegan, T.A., "Union Carbide Purox System for Solid Waste Disposal and Resource Recovery," Energy from Solid Waste Utilization, Proceedings of the Sixth Annual Northeastern Regional Anti-

- Pollution Conference, 1975a.

Dow Chemical Company, Energy Industrial Cențer Study, June 1975.

EPRI, "Municipal Solid Wastes-Problem or Opportunity?," EPRI Journal, Volume 2, Number 9, November 1977.

Franklin, W.E., D. Bendersky and W.R. Park, "Energy Recovery Systems for Municipal Solid Waste-A Technical/Economic Review and Forecast," in (D.E. Earley et al., editor) Energy and the Environment, Proceedings of the Second National Conference, American Institute of Chemical Engineers.

General Electric Company, Solid Waste Management: Technology Assessment, 1975.

Golueke, C.G. and P.H. McGauhey, "Waste Material," in Annual Review of Energy, Volume 1, ERDA, 1976. 
REFERENCES (cont inued)

Gordian Associates, Inc., Overcoming Institutional Barriers to Solid Waste Utilization as an Energy Source, HCP/6-50172-02, 1977.

Govan, F.A., D. Martin and R.J. Monrol, "The Combustion of Municipal Solid Waste as a Primary Fue1," in (D.E. Earley et al., editor), Energy and the Environment, Proceedings of the Second National Conference, American Institute of Chemical Engineers.

Hann, J.L., Study of Delaware County No. 3 Incinerator in Brooma11, Pennsylvania, Solid Waste Management Office, EPA, Division of Technical Operations Open File Report to 3.1.010/0, 1970.

Hamabe, I., T. Tsugeno and S. Nozu, "Pyrolyzing Test of Municipal Wastes in Japan, in Convorsion of Refuse to Energy; Tristitute of Electrical and Electronic. Engineers, Inc., Piscataway, N.J., 1975.

Holloway, J.R., "EPA Resource Recovery Demonstration: Summary of A1r Emissions Analysis," Waste Age, August 1976.

Holloway, Robert, "Comparing the Ames and St. Louis Resource Recovery Projects," Waste Age, February 1978.

Hunt, R.G., M.A. Franklin and W.E. Franklin, "R\&्कD Resources Recovery Acitivties Report," Resources Recovery and Conservation, 3, 1978.

International Research and Technology Corporation, Problems and.Opportunities in Management of Combustible Solid Wastes, 1972.

Javetsk1, John, "Cogeneration: Washington Fiddles While Industry Burns," in Power, Volume 122, Number 4, April 1978.

Jet Propulsion Laboratory, Potential for Cogeneration of Heat and Electricity in Callfomia Industry, Phase I Final Report, JPL Publication 78-42, May 1978.

Kaiser, E.R., "Refuse Reduction Processes," in (L. Weaver, editor) Proceedings: The Surgeon General's Conference on Solid Waste Management for Metropolitan Washington, Department of Health, Education and Welfare, July 1967.

Kaiser, E.R., "Composition and Combustion of Refuse," in (R. Fox, editor), Proceedings of Mecar Symposium-Incineration of Solid Waste, 1967a.

Kilgroe, J.D. et al., Emissions and Energy Conversion from Refuse Processing and Mixed Fuel Boiler Firing, First International Conference on Conversion of Refuse to Energy, Montreux, Switzerland, 1975.

Kilgroe, J.E. et a1., Environmental Studies on the St. Louis Union Electric Refuse Firing Demonstration, Symposium on Clean Fue 1 from Biomass Sewage, Urban Refuse and Agricultural Wastes, 1976.

Klumb, D., "Union Electric Company's Solid Waste Utilization System," Resource Recovery and Conservation, 1, 1976.

Lawler, S.P., "The Americology System (Milwaukee)," in (S.M. Barnett et al., editor) Energy from Solid Waste Utilization, Proceedings of the Sixth Annual Northeastern Regional Anti-Pollution Conference, 1975. 
REFERENCES (continued)

Lipshutz, T. et al., Garbage-to-Energy, the False Panacea, Santa Rosa Recycling Center, 1978 .

Leighton, A. and Patek, Combination Thermal Drive to Recover Very Heavy Oil from Paris Valley Field, ERDA-Enhanced Oil Recovery Symposium, 1976.

Macadam, W.K., "Design and Pollution Control Features of the Saugus, Massachusetts Generating Refuse Energy Plant," Resource Recovery and Conservation, $1,1976$.

Marple, D.D., "Energy. Recovery from Mixed Municipal Refuse-The Purox System," in (D.E. Earley et al.,, editors) Energy and the Environment, Proceedings of the Second National Conference, American Institute of Chemical Engineers, 1974 .

McFarland, J.M. et al., Comprehensive Studies of Solid Wastes Management, University of California Sanitary Engineering Research Laboratory, SERL Report No. 72-3, 1972.

Moore, H.C., "Refuse Fire Steam Generator at Navy Base, Norfolk, Va.," in ( $R$. Fox, editor) Proceedings of the Mecar Symposium-Incineration of Solid Waste, 1967.

Nuss, G.R. et al., Base Line Forecasts of Resource Recovery, 1972 to 1990, Midwest Research Institute, EPA Publication No. SW-1076, $\overline{1975}$.

Oak Ridge National Laboratory, "Municipal Solid Waste Disposal," Net Energy Analysis of Five Energy Systems, Chapter 6, 1976.

Oklahoma University, Energy Alternatives, May 1975.

Ongerth, J.E. and M.G. Tucker, Report on a Study of the Weber County Incinerator in Ogden, Utah, Office of Solid Waste Management, EPA, Division of Technical Operations Open File Report to.3.1.001/8, 197,0 .

Personal communications with members of the Engineering Department of the Sanitation District \#2 of Los Angeles County, Whittier, California.

St. Clair, W., "Resource Recovery-A Review," Waste Age, June 1975.

Sathaye, J. et a1., Analysis of the California Energy Industry, Lawrence Berkeley Laboratory, LBL-5928, 1977.

Scharner, C.D., Testimony on the Purox System of Energy Conversion, Presented to the Oversight Hearings on the State Solid Waste Management Board by the California Legislative Assembly Committee on Resources, Land Use and Energy, 1976.

Schulz; H.W., "Energy from Municipal Refuse: A Comparison of Ten Processes," Professional Engineer, November 1975.

Schulz, H.W., "Assessment of Purox Pilot Plant Performance (Task 9)," in A Pollution-Free System for the Economic Utilization of Municipal Solid Waste, Columbia University, $19.75 a$.

Sessler, G. and P.M. Cukor, Pollutant Releases, Resource Requirements, Costs and Efficiencies of Selected New Energy Technologies,

Teknekron, Inc., 1975. 
REFERENCES . (cont inued)

Sheng, H.R. and H. Alter, "Energy Recovery from Mhnicibal Sol id Waste and Method of Comparing Refuse-Derived Fuels," Resource Recovery and Conservation, $1,1975$.

Sheridan, J.H., "Garbage Power," Industry Week, April 19, 1976.

Stallings, J.W., "The Economics of Resource Recovery," in (D.E. Early et al., editors) Energy and the Environment, Proceedings of the Second National Conference, American Institute of Chemical Engineers, 1974 .

Sussman, D.B., Baltimore Demonstrates Gas Pyrolysis-The Energy Recovery Golid Waste Facility in Baltimore, Maryland, Prepared for Environmental Protection Agency, 1974.

Teknekron, Inc., Pollutant Reseases, Resource Requirements, Costs and Efficiencies of Selected New Energy Technologies, 1975.

Thermo Electron Curporation, A Study of Inplant Flectric Power Cogeneration in the Chemical, Petroleum Refinery, and Paper and Pulp Industries, June 1976.

Union Carbide Corporation, Slide Summary and Informal Narrative of a Purox Co-Disposal Program, 1977.

U.S. Environmental Protection Agency, Resource Recovery Plant Implementation Guide for Municipal Officials-Technology, Document No. SW-500, 1976.

U.S. Environmental Protection Agency, Decision Makers Guide to Solid Waste Management, 1976 .

U.S. Environmental Protection Agency, U.S. Municipal Sludge Management: EPA Construction Grants Program, $1976 \mathrm{~b}$.

U.S. Envirnnmental Protection Agency, Fourth Report to Congress: Resource Recovery and Waste Reduction, Publication No. SW-600, 1977.

University of California, Municipal Incineration, SERL Bullet in No. 5, 1951.

Walker, A.B., "Air Pollution Control Equipment for Incinerators," in (R. Fox, editor) Proceedings of the Mecar Symposium-Incineration of Solid waste, 1967 .

Yaverbaum, Lee, FBC of Coal and Waste Materia1s, Park Ridge, NJ: Noyes Publishers, 1977. 